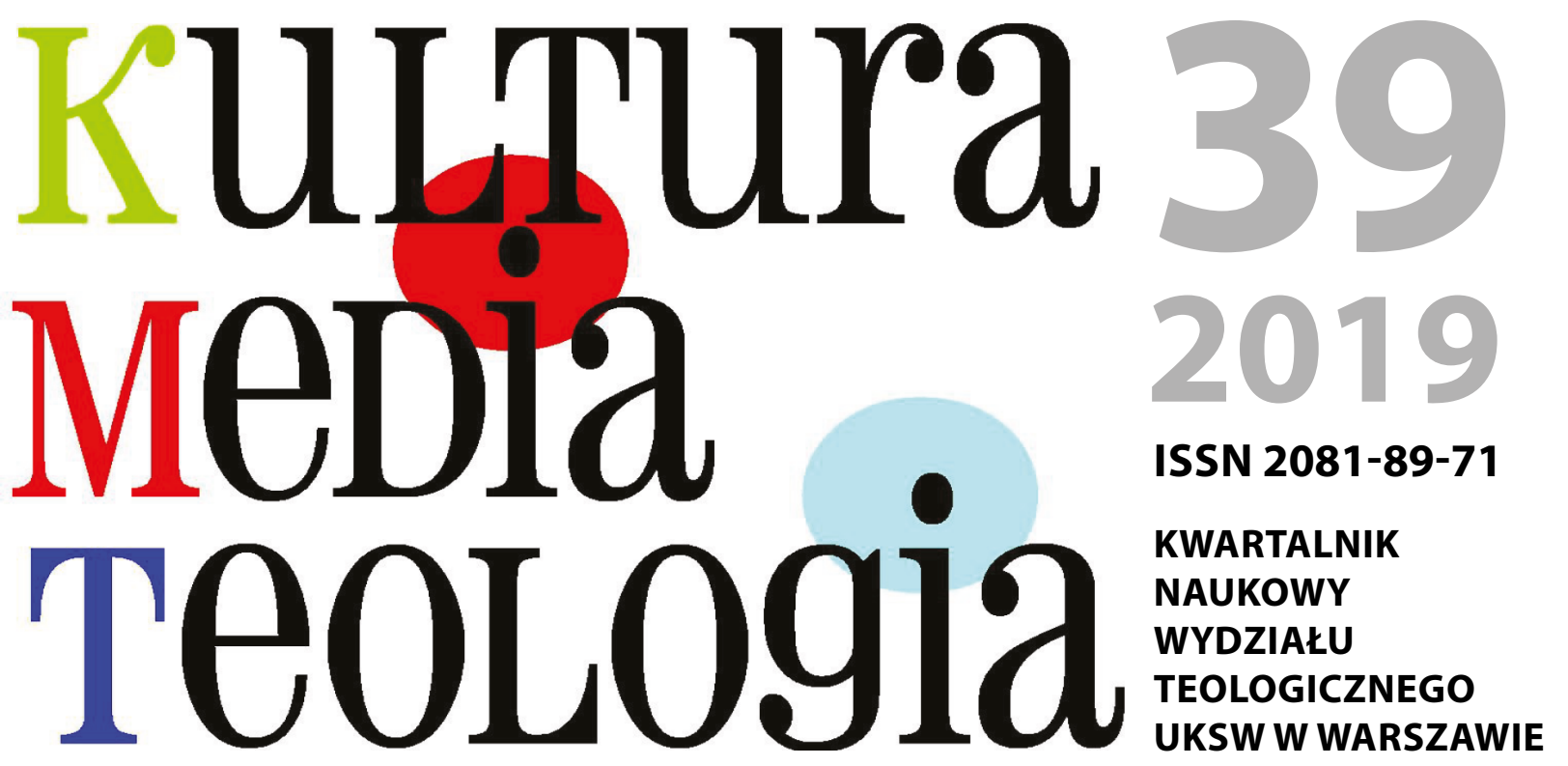

1011011011

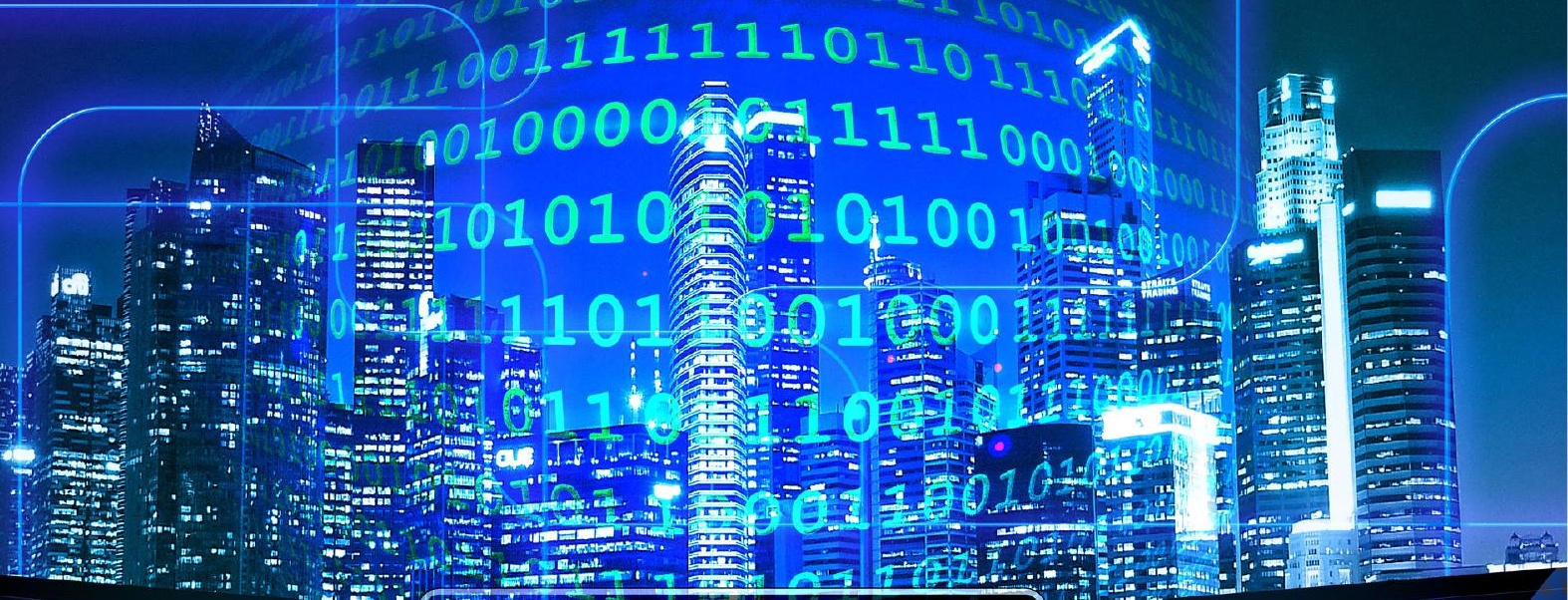
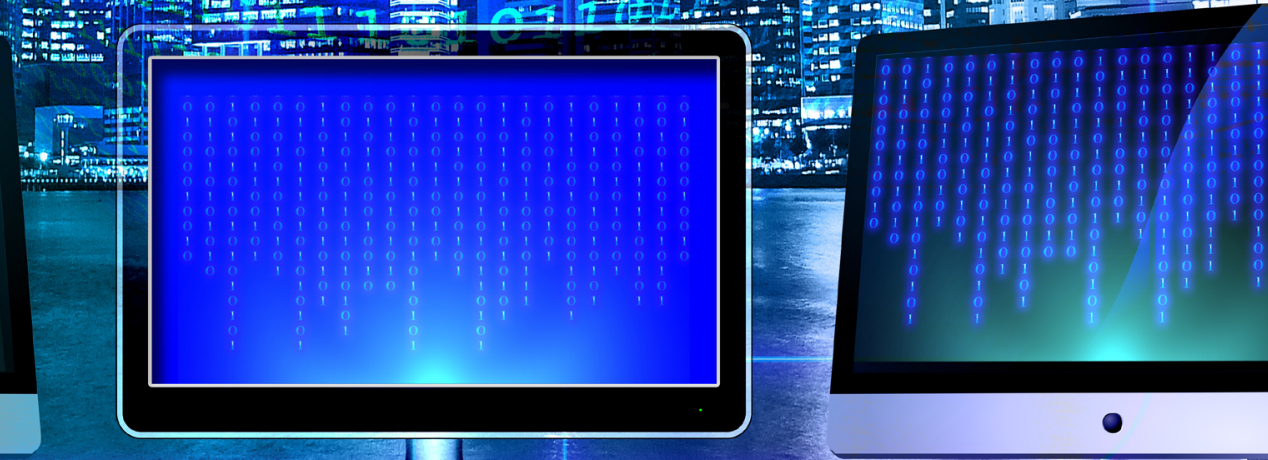

- 



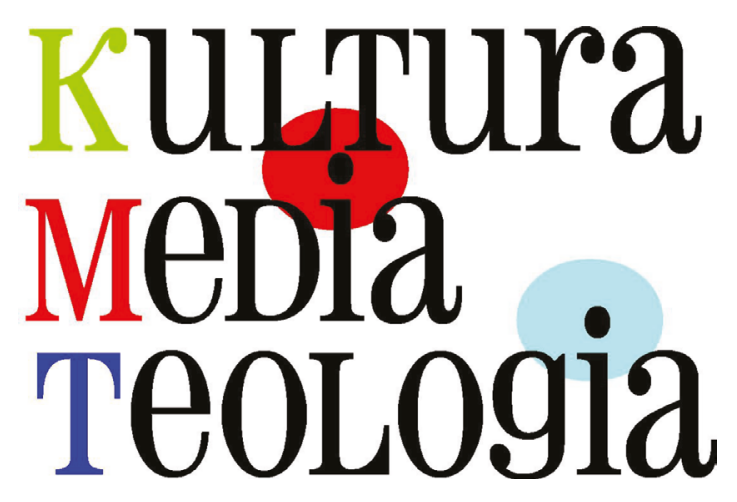

NUMER 39/2019

TEMAT NUMERU:

KOMUNIKACJAW MEDIACH, KULTURZE ITEOLOGII 


\section{KULTURA - MEDIA - TEOLOGIA}

KWARTALNIK NAUKOWY WYDZIAŁU TEOLOGICZNEGO UKSW W WARSZAWIE

ISSN 2081-8971

WYDAWCA:

REDAKCJA:

Rada naukowa:

Korekta:

Skład:

Logo:

Adres redakcji:

Kontakt:
Wydział Teologiczny Uniwersytetu Kardynała Stefana Wyszyńskiego w Warszawie, ul. Dewajtis 5, 01-815 Warszawa

dr hab. Katarzyna Flader-Rzeszowska, prof. UKSW

(redaktor naczelna)

dr hab. Monika Przybysz, prof. UKSW (zastępca red. nacz.)

dr Marta Jarosz (sekretarz redakcji)

dr Marek Robak

dr Dagmara Jaszewska

ks. dr hab. Dariusz Pater

dr hab. Małgorzata Laskowska

ks. dr hab. Norbert Mojżyn

ks. prof. dr hab. Stanisław Dziekoński (UKSW)

ks. prof. dr hab. Witold Kawecki (UKSW)

ks. prof. dr hab. Henryk Seweryniak (UKSW)

prof. dr hab. Jan Stanisław Wojciechowski (UJ)

prof. dr hab. Rafał Habielski (UW)

prof. dr hab. Jerzy Olędzki (UKSW)

prof. dr hab. Anna Zeidler-Janiszewska (SWPS)

prof. dr hab. Karol Klauza (KUL)

prof. dr Michał Masłowski (Université Paris IV - Sorbonne)

Prof. Andrius Vaišnys, Uniwersytet Wileński

Doc. Mgr. Katarína Fichnová, PhD. - Uniwersytet Konstantyna

Filozofa w Nitrze (Słowacja)

dr hab. Mariola Marczak prof. UWM Olsztyn

dr hab. Anna Czajka-Cunico prof UKSW

dr Victor Khroul Państwowy Uniwersytet im. Łomonosowa

w Moskwie

dr hab. Monika Przybysz, prof. UKSW

i dr Marta Jarosz

oraz Zespół

Stanisław Tuchołka • www.panbook.pl

ks. dr hab. Andrzej Adamski, prof. WSIiZ;

fot. na okładce: https://www.pexels.com/photo/nature-laptopoutside-macbook-6508/

„Kultura-Media-Teologia”, ul. Dewajtis 5, 01-815 Warszawa, e-mail: kmt.uksw@gmail.com; http://www.kmt.uksw.edu.pl

Redakcja zastrzega sobie prawo skracania i redagowania tekstów oraz zmiany tytułów. Materiałów niezamówionych nie odsyłamy. Wersję pierwotną (referencyjną) wydawanego czasopisma stanowi publikacja online dostępna na stronie kmt.uksw.edu.pl 


\section{SPIS TREŚCI}

KOMUNIKACJA I NOWE MEDIA $\ldots \ldots \ldots \ldots \ldots \ldots \ldots \ldots \ldots \ldots \ldots \ldots \ldots, 7$

Marek Kochan

KOMUNIKACJA KRYZYSOWA JAKO CZYNNIK ROZWOJU KRYZYSU ...... 8 Zofia Sawicka

CZY DŻIHAD MOŻE BYĆ COOL? NOWE MEDIA W SŁUŻBIE ZBROJNEGO

DŻIHADU

Marta Jarosz

MOŻLIWOŚCI KONTRA OCZEKIWANIA. JAK KOMUNIKUJĄ SIĘ

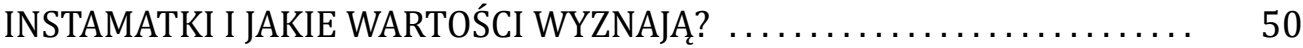

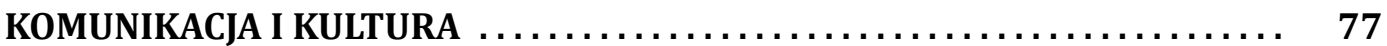

Witold Wołowski, Renata Jakubczuk

LA FICTION PEUT-ELLE ÊTRE RÉALISTE ? DEUX VISIONS THÉÂTRALES

DU SUPERMARCHÉ : LE GRAND CHARIOT DE JACKY VIALLON (1993)

ET BONZY, LA VIE, MORT OU VIF D'ALAIN COFINO GOMEZ (2013) .......

Agnieszka Włoczewska

W HOŁDZIE PARYSKIEJ NOTRE-DAME. KATEDRA NAJŚWIĘTSZEJ MARII

PANNY JAKO OBRAZ W LITERATURZE I JAKO TEKST NIEWERBALNY ....

Robert Nęcek

UNDERSTANDING JOHN PAUL II'S COMMUNICATION

WITH THE CONTEMPORARY WORLD ON THE EXAMPLE

OF JOANNA SOBCZYK-PAJAK'S PAINTING

KOMUNIKACJA I TEOLOGIA

Tomasz Kopiczko

CATECHESIS AND NEW EVANGELIZATION IN THE FACE

OF CONTEMPORARY CHALLENGES OF SOCIAL COMMUNICATION

Marcin Wrzos

APOSTOLISCHE AUSLANDSREISEN VON PAPST FRANZISKUS,

DARUNTER MISSIONSREISEN, IN DEN WICHTIGSTEN NATIONALEN

INTERNETPORTALEN (JAHR 2017) 



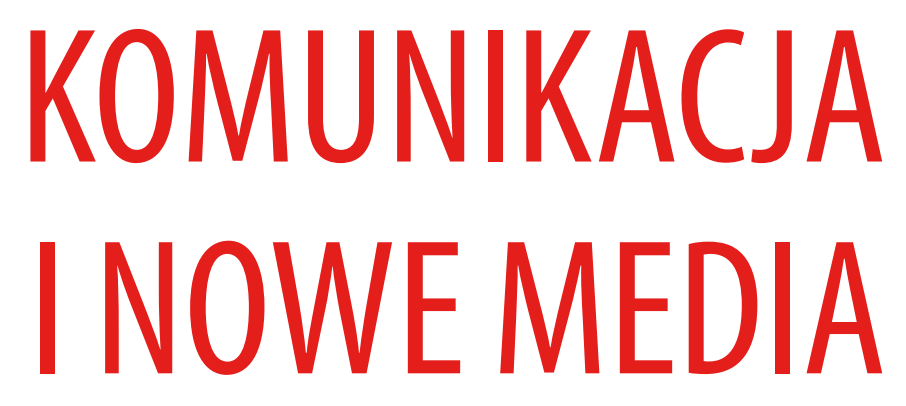

KULTURA - MEDIA - TEOLOGIA 39/2019 
KULTURA - MEDIA - TEOLOGIA

ISSN 2081-89-71

2019 nr 39, s. 8-31

\section{Marek Kochan}

Katedra Dziennikarstwa, Uniwersytet SWPS

\section{Komunikacja kryzysowa jako czynnik rozwoju kryzysu}

\section{Crisis communication and potential intensification of crisis}

\begin{abstract}
ABSTRAKT
Tematem artykułu jest komunikacja

kryzysowa w mediach i w polityce.

Autor, wychodząc od definicji kryzysu wizerunkowego i opisywanych w literaturze reguł komunikacji kryzysowej, analizuje

zachowania, które zamiast redukować

skutki kryzysów - intensyfikują je.

W tekście omawiane są na konkretnych przykładach następujące błędy komunikacji kryzysowej: 1. Mijanie się z prawdą, 2. Brak odniesienia się do zarzutów, 3. Agresja w komunikacji kryzysowej, 4. Brak empatii,

5. Niespójność komunikatu, 6. Pójście pod prąd oczekiwaniom opinii publicznej, a więc

lekceważenie zaniepokojenia odbiorców. W końcowej części tekstu autor wskazuje zasady, których przestrzeganie wzmacnia skuteczność komunikacji kryzysowej.
\end{abstract}

\section{SŁOWA KLUCZOWE:}

kryzys medialny, komunikacja polityczna, komunikacja kryzysowa, wizerunek firmy, wizerunek osobisty, wizerunek polityczny

\section{ABSTRACT}

The topic of this article is crisis communication in media and in politics. The author discusses the definitions of crisis and the rules of crisis communication, and then analyses several case studies of crisis communication when the crisis in not reduced but intensified. Six mistakes in crisis communication are analysed in the article: 1 . Falsehood, 2. Missing the allegation, 3. Agression, 4. Lack of empathy, 5. Massage inconsistency, 6. Missing the expectations of the audience. In the last part of the article the author discusses the issue of creating effective crisis communication and its rules.

\section{KEYWORDS:}

media crisis, political communication, crisis communication, corporate image, personal image, political image 


\section{WSTĘP}

Kryzys wizerunkowy definiowany jest zwykle jako zagrożenie dla firmy: wydarzenie (lub zbiór wydarzeń) negatywnie wpływające na jej funkcjonowanie, stawiające ją w negatywnym świetle ${ }^{1}$, stanowiące zagrożenie dla jej działalności i zakłócające równowagę ${ }^{2}$ czy normalny rytm jej funkcjonowania i mające istotny wpływ na kształt procesów, jakie w niej zachodzą ${ }^{3}$, bądź narażających skuteczną realizację misji i założonych celów organizacji, marki lub osoby publicznej'

Tymczasem w myśleniu o kryzysie równie, a może bardziej istotny jest inny element: możliwość podjęcia działań nie tylko niwelujących negatywne skutki kryzysu, ale nawet przynoszących firmie korzyści wizerunkowe. Te dwa wymiary kryzysu (zagrożenie i zarazem szansa) są widoczne w sposobie zapisywania tego słowa w językach chińskim i japońskim. „Kryzys” składa się w nich z dwóch znaków: jeden znaczy „niebezpieczeństwo”, „bliska, nieunikniona ruina”, drugi zaś oznacza „okazję, możliwość, coś w rodzaju perspektywy otwierającej się w przyszłości ${ }^{5}$.

Ta szansa jest związana $\mathrm{z}$ działaniami, jakie podejmie firma $\mathrm{w}$ celu rozwiązania kryzysu, stąd w innym ujęciu „kryzys to problem na który trzeba zareagować”, najlepiej w sposób natychmiastowy ${ }^{6}$. Reakcja dotyczyć powinna zarówno problemu, który może stać się źródłem kryzysu, najlepiej jeszcze przed jego upublicznieniem (wtedy można uniknąć kryzysu wizerunkowego: problem nienagłośniony nie przekształca się w kryzys), jak i - w sytuacji, gdy negatywne zdarzenia są już upublicznione - działań komunikacyjnych, które mają zniwelować negatywne skutki kryzysu i ewentualnie przekształcić je w zyski wizerunkowe. Oczywiście, nie zawsze jest to możliwe, czasem celem maksimum jest tylko ograniczenie negatywnych skutków kryzysu.

${ }^{1}$ L. Kamiński, Komunikacja korporacyjna a biznes, Bydgoszcz-Warszawa 2007, s. 62.

${ }^{2}$ T. Smektała, Public relations w sytuacjach kryzysowych przedsiębiorstw, Wrocław 2005, s. 65 .

${ }^{3}$ D. Tworzydło, Procedura zarządzania $w$ kryzysie wizerunkowym $w$ mediach - przeciwdziałanie, reagowanie oraz odzyskiwanie wizerunkowych korzyści „Studia Medioznawcze” 3 (70)/2017, s. 77.

${ }^{4}$ M. Kaczmarek-Śliwińska, Public Relations $w$ zarzq̨dzaniu sytuacjami kryzysowymi $w$ organizacji. Sztuka komunikowania się, Warszawa 2015, s. 54.

${ }^{5}$ J. Walas-Trębacz, J. Ziarko, Podstawy zarządzania kryzysowego, Cz. 2, Zarządzanie kryzysowe w przedsiębiorstwie, Kraków 2011, s. 18.

${ }^{6}$ J. Cornelissen, Komunikacja korporacyjna, Warszawa 2012, s. 249. 
Tematem niniejszego tekstu jest właśnie komunikacja kryzysowa rozpatrywana w perspektywie rozwiązania kryzysu lub potencjalnie - jego intensyfikacji. Chciałbym na podstawie analizy wybranych przypadków wskazać takie zachowania komunikacyjne, które zamiast redukować kryzys eskalują go. W części podsumowującej artykuł celem będzie natomiast wskazanie zasad komunikacji kryzysowej, których przestrzeganie może ograniczyć prawdopodobieństwo rozwoju kryzysu.

\section{MECHANIZMY KOMUNIKACJI KRYZYSOWEJ}

Badacze zajmujący się kryzysami wizerunkowymi poświęcają dużo uwagi mechanizmom komunikacji, w szczególności zasadom, jakich powinny przestrzegać firmy, by minimalizować negatywne skutki kryzysów i w miarę możliwości przekuwać zagrożenie w korzyści wizerunkowe.

Niektórzy uważają, że takie zasady nie istnieją i nie ma jednego dobrego wzorca komunikowania się, a można jedynie wskazać dobre i złe praktyki, uwzględniając specyfikę organizacji, kontekst społeczny i publiczny, predyspozycje osób komunikujących się czy konkretny moment sytuacji kryzysowej ${ }^{7}$. Jednak większość badaczy i specjalistów jest zdania, że można określić zasady, których przestrzeganie wpływa na skuteczność w rozwiązywaniu kryzysu. Zasady te bywają różnie sformułowane, jednak można zauważyć powtarzające się motywy. Zwykle podkreśla się konieczność mówienia prawdy, podawania tylko sprawdzonych informacji ${ }^{8}$, co oznacza także, że nie można zaprzeczać faktom ${ }^{9}$ czy rzeczom oczywistym $^{10}$. Druga sprawa to szybkość, komunikowanie się od samego początku ${ }^{11}$, trzecia: traktowanie mediów w sposób otwarty i partnerski, regularne udzielanie informacji, informowanie na bieżąco ${ }^{12}$, wreszcie, co do stylu komunikacji: przekazywanie informacji krótkich, niedających podstaw do manipulacji ${ }^{13}$,

${ }^{7}$ M. Kaczmarek-Śliwińska, dz. cyt., s. 159.

${ }^{8}$ Por. L. Kamiński, dz. cyt., T. Smektała, dz. cyt., Tworzydło, dz. cyt. , M. Kaczmarek-Śliwińska, dz. cyt.

${ }^{9}$ M. Kaczmarek-Śliwińska, dz. cyt., s. 160.

${ }^{10}$ L. Kamiński, dz. cyt., s. 65.

${ }^{11}$ M. Regester, J. Larkin, Zarządzanie kryzysem, Warszawa 2005, L. Kamiński, dz. cyt., T. Smektała, dz. cyt.

${ }^{12}$ D. Tworzydło, dz. cyt., T. Smektała dz. cyt., M. Regester J. Larkin dz. cyt.

${ }^{13}$ D. Tworzydło, Public Relations praktycznie, Rzeszów 2017, s. 193. 
unikanie niespójności (wewnątrz komunikatów i pomiędzy różnymi podmiotami reprezentującymi tę samą organizację), a także dywagacji i spekulacji - odpowiadanie dopiero po zweryfikowaniu faktów ${ }^{14}$; komunikowanie się pewnie i z wiarą oraz unikanie żargonu technicznego ${ }^{15}$. Błędem jest też okazywanie agresji i nadmiernych emocji w stosunku do dziennikarzy (i szerzej - wobec różnych przedstawicieli opinii publicznej np. internautów), może to bowiem być przyczyną kolejnej sytuacji kryzysowej ${ }^{16}$.

Ważnym zagadnieniem, ujmowanym w różny sposób, jest postawa w komunikowaniu: nie ograniczanie się do faktów, ale też okazanie, że patrzy się z punktu widzenia poszkodowanych ${ }^{17}$, rozumie się powagę sytuacji i zaniepokojenie opinii publicznej; wyrażanie współczucia dla ofiar (jeśli takie są) i ew. ich krewnych, a także żalu i skruchy z powodu popełnionych błędów ${ }^{18}$, czyli, ujmując to lapidarnie, pokazywanie „ludzkiej twarzy” w kryzysie.

Komunikacja nie powinna jednak ograniczać się do wyrażenia współczucia, należy zająć się naprawieniem błędów, wyciągnąć wnioski na przyszłość, starać się obiecać pomoc i naprawić sytuację ${ }^{19}$. Kryzys obejmuje bowiem zarówno realny problem, jak i komunikację. Te obszary muszą być ze sobą powiązane. Trzeba jednocześnie rozwiązywać problem i komunikować się, a najlepiej komunikować to, jak firma zajmuje się naprawieniem sytuacji. Kryzysu nie zażegna ani sama komunikacja (gdy problem nie jest rozwiązany), ani same działania bez komunikacji, gdy opinia publiczna nie dowie się, że zostały one podjęte.

Nie sposób przywołać w niniejszym artykule licznych typologii kryzysów, z których wiele odnosi się do ich przyczyn ${ }^{20}$. Firmy upatrują źródeł kryzysów wizerunkowych najczęściej w zaburzeniach swojego normalnego funkcjonowania (takich jak wypadki, problemy techniczne, zagrożenie dla zdrowia konsumentów, zagrożenia dla środowiska, zła kondycja finansowa, malwersacje, zwolnienia, złe traktowanie pracowników, naruszanie prawa itp.). Wśród wskazywanych w badaniu przyczyn kryzysu w mediach wskazywano najczęściej na jakość produktów

\footnotetext{
${ }^{14}$ M. Kaczmarek-Śliwińska, dz. cyt.

${ }^{15}$ T. Smektała, dz. cyt.

${ }^{16}$ Tamże, s. 163.

17 Tamże, s. 163.

${ }^{18}$ L. Kamiński dz. cyt., T. Smektała, dz. cyt., M. Regester, J. Larkin, dz. cyt.

${ }^{19}$ L. Kamiński dz. cyt., T. Smektała, dz. cyt.

${ }^{20}$ Por. np. ich omówienie w: M. Kaczmarek-Śliwińska, dz. cyt., s. 73-88.
} 
(30\%), wypadki przy pracy (15\%), awarie (7\%), niezadowolenie konsumentów $(11 \%)$ i ich negatywne komentarze w mediach społecznościowych $(11 \%)^{21}$.

Tymczasem współcześnie bardzo często to działania komunikacyjne firm, instytucji i osób publicznych są obszarem, w którym pojawia się kryzys. Istnieje wiele przykładów na to, że źródłem sytuacji kryzysowej są już nie tyle realne działania firm czy ich pracowników, ile źle przygotowane akty komunikacji, wywołujące oburzenie i sprzeciw odbiorców. Kryzysy wywołane przez niewłaściwą komunikację mogą realnie wpłynąć na funkcjonowanie firmy czy instytucji (partii politycznej, rządu), poprzez bojkot ze strony konsumentów czy spadek poparcia, a w niektórych przypadkach zagrozić nawet istnieniu organizacji ${ }^{22}$.

\section{Źródłem sytuacji kryzysowej są już nie tyle realne działania firm czy ich pracowników, ile źle przygotowane akty komunikacji, wywołujące oburzenie i sprzeciw odbiorców.}

Przykładem może być choćby poprzedzająca święta Bożego Narodzenia kampania Empiku, w której wykorzystano dwie kontrowersyjne postacie: Adama Darskiego „Nergala”, znanego z antyklerykalnych poglądów i wsławionego publicznym spaleniem Biblii, oraz Marię Czubaszek, deklarującą, że dwa razy dokonała aborcji i jest z tego zadowolona. Jakkolwiek ci bohaterowie mają prawdopodobnie swoje grupy wielbicieli, ich poglądów nie podziela jednak mainstream klientów Empiku. Reakcja na kampanię była negatywna, spowodowała bojkot konsumencki ${ }^{23}$ i falę niechęci, która ujawniła się m.in. w memach, łączących postacie Darskiego i Czubaszek z cytatami z ich wypowiedzi z hasłem: „Empik zaprasza na świąteczne zakupy” (Nergal: „Pokazałem Bogu środkowy palec”, „Dekalog mi się

${ }^{21}$ http://nextday.pl/blog/kryzys-wizerunkowy/, dostęp 4 listopada 2019.

22 J. Cornelissen, dz. cyt., s. 247.

${ }^{23}$ https://www.wirtualnemedia.pl/artykul/klienci-empiku-krytykuja-kampaniebozonarodzeniowa-z-nergalem-i-czubaszek-nie-ma-mowy-o-bojkocie (dostęp 15 października 2019). 
nie podoba”24; Czubaszek: „Mówiłam zawsze: Boże, jak to cudownie, że ja to zrobiłam - M. Czubaszek o dwóch przeprowadzonych aborcjach"25).

Drugi podobny przykład to niefortunna reklama wódki Żytnia, a ściśle post na facebookowym profilu producenta Żytniej, prowadzonym przez zewnętrzną agencję marketingową. Post, w zamierzeniu prawdopodobnie humorystyczny, wykorzystywał (bez zgody autora) zdjęcie z manifestacji z 1982 roku w Lubinie, przedstawiające demonstrantów uciekających z pacyfikowanej demonstracji i niosących swojego kolegę, postrzelonego przez milicję; poniżej na czerwonym pasku znajdował się napis: „KacVegas? Scenariusz pisany przez Żytnią”26. Niestosowność użycia tego akurat zdjęcia w reklamie wódki i z takim podpisem wywołała sprzeciw opinii publicznej, w tym rodzin osób przedstawionych na zdjęciu, a także związku zawodowego Solidarność, który wytoczył producentowi Żytniej proces. Firma rozwiązała umowę z agencją marketingową, ta zaś zwolniła pracownicę odpowiedzialną za post (co ciekawe absolwentkę historii), która też miała sprawę w sądzie o zniesławienie pamięci manifestantów. Sprawa odbiła się głośnym echem w mediach i stała się przykładem nieprzemyślanych działań marketingowych generujących ogromne straty wizerunkowe.

Trzeci podobny przykład to reklama (w formie postu na Facebooku) napoju energetycznego Tiger, nawiązująca obraźliwym gestem do rocznicy wybuchu Powstania Warszawskiego (dłoń z wysuniętym środkowym palcem ozdobionym czerwoną wstążką pod napisem „1 sierpnia dzień pamięci”, poniżej kontur tygrysa mówiącego w dymku "Chrzanić to, co było, ważne to, co będzie”) ${ }^{27}$.

W tym wypadku agencja reklamowa posłużyła się prowokacją, chcąc zwrócić uwagę na produkt. Nie doceniła jednak reakcji opinii publicznej, która zmusiła producenta Tigera, koncern Maspex Wadowice, do publicznych przeprosin i zaangażowania się w działania na rzecz upamiętnienia Powstania Warszawskiego.

${ }^{24}$ http://niezalezna.pl/61247-nergal-i-czubaszek-w-wigilijnej-reklamie-empik-nacelowniku-internautow (dostęp 15 października 2019).

${ }^{25}$ https://www.pch24.pl/obroncy-zycia-pikietuja-przeciwko-promocji-mariiczubaszek-,32203,i.html (dostęp 15 października 2019).

${ }^{26}$ https://dziennikpolski24.pl/zdjeciem-ofiary-zomo-promowali-wodke-w-sieciwideo/ar/6241488 (dostęp 4 września 2018).

${ }^{27}$ http://wiadomosci.dziennik.pl/media/artykuly/555912,tiger-maspex-napojpromocja-na-1-sierpnia-srodkowy-palec-na-plakacie.html (dostęp 15 października 2019). 
Przykłady te były opisywane i analizowane w publikacjach naukowych ${ }^{28}$, a także w mediach, m.in. w prasie marketingowej, stąd w niniejszym artykule przedstawione są tylko szkicowo, jako egzemplifikacja tezy, iż niewłaściwa w formie lub w treści komunikacja może stać się przyczyną kryzysu.

Wśród czynników mogących wpłynąć na eskalację kryzysu Monika Kaczmarek-Śliwińska wymienia: 1. Działania konkurencji, 2) sytuację gospodarczą, społeczną czy polityczną, 3) emocje, które mogą towarzyszyć sytuacji kryzysowej ${ }^{29}$. Do tej listy należy dodać jeszcze jeden czynnik: samą komunikację kryzysową, nie spełniającą oczekiwań opinii publicznej - często to właśnie ona może powodować eskalację kryzysu.

To właśnie zagadnienie jest głównym tematem artykułu. Na podstawie omówionych wyżej zasad komunikacji kryzysowej można wskazać kilka błędów, które mogą prowadzić do zaognienia kryzysu. Należą do nich podawanie nieprawdziwych informacji, brak polemiki z zarzutami, napastliwy styl, przyjęcie nieempatycznej postawy wobec ofiar kryzysu, komunikacja niespójna wewnętrznie albo niespójna z oczekiwaniami opinii publicznej. W dalszej części tekstu poszczególne błędy w komunikacji kryzysowej zostaną omówione na podstawie przykładów. Każdy z nich zostanie poddany analizie, skupiającej się na przedstawieniu istoty i tła kryzysu oraz na treści i formie komunikacji kryzysowej, analizowanej z punktu widzenia skuteczności w rozwiązywaniu kryzysu.

Sześć błędów w komunikacji kryzysowej zostanie omówionych na podstawie analizy sześciu kryzysów wizerunkowych:

1. Mijanie się z prawdą (K. Durczok);

2. Brak odniesienia się do zarzutów (B. Jóźwiak);

3. Agresja w komunikacji kryzysowej (J. Kuźniar);

4. Brak empatii (E. Bieńkowska);

5. Niespójność komunikatu (R. Petru);

6. Pójście pod prąd oczekiwaniom opinii publicznej, a więc lekceważenie zaniepokojenia odbiorców (B. Szydło).

${ }^{28} \mathrm{Na}$ temat Tigera por. np. K. Kopeć-Ziemczyk, Jak skutecznie radzić sobie z kryzysem wizerunkowym w mediach społecznościowych - przykład Tigera, „Naukowy Przegląd Dziennikarski" 1/2018, s. 35-54, a także o rok późniejszy artykuł D. Tworzydło, Skuteczne zarzq̨dzanie w kryzysie wizerunkowym na przykładzie marki Tiger, „Studia Medioznawcze” 1(76)/2019, s. $1-14$.

${ }^{29}$ M. Kaczmarek-Śliwińska, dz. cyt., s. 106. 


\section{Mijanie się z prawdą: K. Durczok-TVN}

Kryzys związany z osobą Kamila Durczoka, dziennikarza TVN i szefa Faktów, flagowego programu informacyjnego tej stacji, był związany z zarzutami mobbingu i molestowania, postawionymi Durczokowi w cyklu trzech publikacji tygodnika Wprost. Tygodnik opisał przypadki molestowania „w jednej ze stacji telewizyjnych". W pierwszym materiale nie padało nazwisko Kamila Durczoka, jednak w mediach pojawiły się spekulacje, iż chodzi o szefa „Faktów”. Drugi materiał ${ }^{30}$ opisywał sprawę mieszkania, w którym znaleziono „biały proszek”, gadżety erotyczne oraz rzeczy osobiste należące do Kamila Durczoka, którego obecność w mieszkaniu odnotowała policja, wezwana na interwencję przez właścicieli mieszkania, nie mogących wyegzekwować czynszu od wynajmującej mieszkanie kobiety, znajomej dziennikarza. Publikacja rzucała cień na wizerunek Durczoka, w negatywnym świetle przedstawiając jego życie osobiste.

Kontekstem sprawy była sprzedaż TVN przez ówczesnych właścicieli i prowadzone właśnie wtedy negocjacje dotyczące warunków transakcji i wyceny firmy. Kryzys dziennikarza, szefa i prowadzącego flagowy program informacyjny TVN z pewnością uderzał w wizerunek stacji i obniżał jej wartość. Po drugiej publikacji Kamil Durczok został zawieszony w pełnieniu obowiązków szefa Faktów i w poniedziałek 16 lutego rano udzielił wywiadu Dominice Wielowieyskiej z Tok FM.

W wywiadzie, na zadane wprost przez dziennikarkę pytanie, czy molestował swoje podwładne, Kamil Durczok oświadczył: „Mogę z całq stanowczościq, jasno i wyraźnie powiedzieć: nigdy nie molestowałem żadnej z podległych mi pracownic, nigdy nie molestowałem żadnej kobiety". Gdy dziennikarka powtórzyła pytanie w innej formie, cytując prawniczą definicję molestowania i pytając, czy Durczok może z absolutną pewnością powiedzieć, iż nie naruszył zasad, ten odpowiedział: „Mogę powiedzieć z absolutnq pewnościq, że nie naruszyłem tych zasad”. W dalszej części wywiadu stwierdził jeszcze: „nigdy nie byłem molestującym szefem”31.

W rezultacie sprawy prezes zarządu TVN powołał komisję do zbadania zarzutów mobbingu i molestowania w TVN. 7 marca 2015 wydano komunikat prasowy, podsumowujący pracę komisji. Stwierdzał on iż:

${ }^{30}$ Wprost, nr 8/2015, 16-22 lutego 2015, s. 10-15.

${ }^{31}$ Wywiad z Dominiką Wielowieyską w Tok FM, 16 lutego 2015, https://www.youtube. com/watch?v=YsVotVjITbA (dostęp 15 października 2019). 
Komisja prowadziła swoje działania poprzez rozmowy z 37 obecnymi i byłymi pracownikami i współpracownikami redakcji „Faktów TVN” i zidentyfikowała przypadki niepożądanych zachowań włącznie z mobbingiem i molestowaniem seksualnym. (...) Komisja ustaliła, że trzy osoby zostały narażone na niepożądane zachowania. Jako zadoścuczynienie, TVN S.A. zaoferuje tym osobom kwoty do wysokości 6-krotności ich miesięcznego wynagrodzenia. (...) spółka i pan Kamil Durczok osiągnęli wzajemne porozumienie w sprawie zakończenia współpracy ze skutkiem natychmiastowym. ${ }^{32}$

Można więc powiedzieć, że narracja Kamila Durczoka, który całkowicie wyparł się zarzucanych mu czynów, już wtedy była nie do obrony. Tym bardziej, że tygodnik cytował zeznania konkretnej molestowanej przez niego osoby i esemesy, które miała ona otrzymywać od szefa Faktów. Można więc było założyć, że redakcja dysponuje dowodami, które będzie można przedstawić w sądzie. Mimo tego Kamil Durczok w związku z publikacjami Wprost wytoczył proces tygodnikowi i czwórce dziennikarzy, domagając się 2 mln złotych odszkodowania za publikację dotyczącą molestowania i mobbingu ${ }^{33}$; proces ten przegrał w maju 2018 roku $^{34}$. W sierpniu 2018 roku tygodnik Wprost opublikował artykuł pt. „Durczok. Przerwana tama milczenia”, w którym przywołano uzasadnienie wyroku, potwierdzające winę dziennikarza i podano kolejne fakty dotyczące molestowania i mobbowania przez niego współpracownic ${ }^{35}$.

Być może Kamil Durczok nie zdawał sobie sprawy z tego, że jego zachowania można uznać za mobbing i molestowanie seksualne. Musiał być jednak świadom, że zdarzenia przywołane w publikacji, opisane tam w tych kategoriach (werbalne zaczepki, esemesy) miały miejsce. Zaprzeczając im, mijał się więc z prawdą.

${ }^{32}$ https://prasa.tvn.pl/informacje-korporacyjne/komunikat-prasowy-podsumowujacy-prace-niezaleznej-komisji-badajacej-zarzuty-mobbingu-i-molestowania-w-tvn,160957.html (dostęp 30 sierpnia 2018).

${ }^{33}$ http://www.tokfm.pl/Tokfm/1,130517,18283477,Kamil_Durczok_walczy_o_odszkodowanie_Chce_9_mln_zlotych.html (dostęp 15 października 2019). Durczok wytoczył też drugi proces w związku z publikacją na temat domniemanej ucieczki z mieszkania znajomej, gdzie znajdowały się narkotyki i ostra pornografia, domagając się $9 \mathrm{mln}$ zł odszkodowania (tamże).

${ }^{34}$ https://www.rp.pl/Dobra-osobiste/305159975-Kamil-Durczok-przegral-z-Wprost-w s-publikacji-o-mobbingu-i-molestowaniu-podwladnych.html (dostęp 15 października 2019).

${ }^{35}$ Wprost nr 35/2018, 27 sierpnia - 2 września, s. 16-18. 
Zachowanie dziennikarza naruszyło podstawową zasadę komunikacji kryzysowej: konieczność mówienia prawdy. Zabrakło nie tylko przyznania się do zarzucanych czynów, ale i wyrażenia jakiegoś rodzaju skruchy i przeproszenia poszkodowanych osób. Komunikacja kryzysowa była całkowicie nieskuteczna: nie tylko nie ograniczyła kryzysu, ale przyczyniła się do utraty wiarygodności dziennikarza (gdy niedługo później sam TVN potwierdził prawdziwość zarzutów). Dziennikarz stał się tematem licznych publikacji przedstawiających go w niekorzystnym świetle. Jego wizerunek został zrujnowany, a kariera dziennikarska w pewnym sensie zakończyła się, gdyż mimo kilku prób Durczok nie odzyskał dawnego znaczenia i pozycji.

\section{Brak odpowiedzi na zarzuty: B. Jóźwiak}

Kryzys Bartosza Jóźwiaka, posła partii Kukiz 15, rozpoczął się od publikacji dziennika „Fakt” z 13 marca 2018, pt. „Poseł mieszka u kochanki. I to za nasze”. Tabloid poinformował, że poseł wynajmuje mieszkanie od swojej dobrej znajomej za 2200 zł, zatrudnia ją też w biurze poselskim za 3000 zł. Publikacja była zilustrowana zdjęciami, wskazującymi na bliską zażyłość lub wręcz intymną relację, łączącą żonatego posła z jego współpracownicą ${ }^{36}$, zawierała też kopię umowy na wynajem mieszkania ${ }^{37}$.

Kryzys obejmował więc dwa elementy: obyczajowy (domniemany romans posła ze współpracownicą) i etyczny: wynajem mieszkania był zgodny z prawem, podobnie jak zatrudnianie pracownika w biurze poselskim, lecz całość budziła wątpliwości natury moralnej, szczególnie w powiązaniu z domniemaną bliską relacją pomiędzy posłem a współpracownicą, ukazaną na zdjęciach.

Poseł Jóźwiak szybko, bo tego samego dnia nad ranem, o 4.02, umieścił na swoim profilu na Facebooku oświadczenie, w którym odniósł się do sprawy. Publikacja została przez posła zinterpretowana jako atak na jego rodzinę, wynikający z tego, że zajmował się on ważnymi sprawami, m.in. ustawą hazardową, składając interpelacje w sprawie Totalizatora Sportowego i naruszając tym interesy potężnych lobbies. Poseł zadeklarował, że mimo ataków będzie dalej dążył do prawdy, gdyż poważnie traktuje swój mandat poselski.

${ }^{36}$ https://www.fakt.pl/wydarzenia/polityka/posel-kukiz15-bartosz-jozwiak-mieszka-u-kochanki/nj232sf\#slajd-1 (dostęp 15 października 2019).

${ }^{37}$ Tamże. 
Tylko sześć umieszczonych mniej więcej w środku linijek z długiego, liczącego 54 linijki oświadczenia można uznać za pośrednie odniesienie się do zarzutów Faktu:

Nie uznaję takiej formy dziennikarstwa i nie zamierzam polemizować z insynuacjami czy czyimiś fobiami, które jako sensacje przedstawiają umowy (które są normalnymi, prawidłowymi umowami złożonymi w Sejmie), okraszając to tajemniczo brzmiącymi pomówieniami, które mają stworzyć aurę jakichś nieprawidłowości oraz uderzyć w moją rodzinę. ${ }^{38}$

Zabrakło więc komentarza do wątku relacji ze współpracownicą, zaś sprawa wynajmu mieszkania od współpracowniczki została uznana za zgodną z regułami i nie wymagającą tłumaczenia się.

W kolejnych wypowiedziach poseł tłumaczył relację ze współpracownicą („przyjaźnimy się, lecz to nie jest kochanka”, „Zdarzało się jej spać w wynajmowanym przeze mnie mieszkaniu'), co tylko spotęgowało domysły. Do sprawy odniósł się też dwa dni później szef ugrupowania, Paweł Kukiz, dystansując się do sprawy relacji ze współpracownicą („Nie będę wchodził w temat «kochanki», bo nie posiadam wiedzy na temat relacji między posłem a jego asystentkq i szczerze mówiq̨c niewiele mnie one interesujq"). Jednocześnie potępił wynajmowanie od niej mieszkania, jako zgodne z prawem, lecz naganne („Z całq pewnościq wynajmowanie mieszkania od osoby bliskiej za publiczne pieniq̨dze jest dla mnie sprawq moralnie watpliwq"). Kukiz zadeklarował, że przyjrzy się wydatkom z publicznych pieniędzy, jakie ponoszą jego koledzy z klubu, i jeżeli zauważy, że coś jest "etycznie nie tak", wykluczy ich z klubu ${ }^{39}$. W rezultacie po siedmiu dniach od wybuchu kryzysu Bartosz Jóźwiak rozwiązał umowę najmu.

Do komunikacji kryzysowej posła można więc mieć dwojakie zastrzeżenia: pierwsze to brak odniesienia się do problemu w pierwszym oświadczeniu (sprawa i tak wróciła, poseł musiał się tłumaczyć, gdy mógł zamknąć sprawę już na początku), drugie to brak szybkich działań, niwelujących sam problem, w szczególności (ponieważ opinia publiczna okazała większą wrażliwość na sprawę pieniędzy niż na kwestię domniemanych relacji intymnych posła ze współpracownicą)

${ }^{38}$ https://pl-pl.facebook.com/JozwiakBartoszUPR/ (dostęp 30 sierpnia 2018).

${ }^{39} \mathrm{https}$ ///wiadomosci.wp.pl/afera-wokol-mieszkania-dla-kochanki-posla-jozwiakakukiz-stawia-ultimatum-6230449204029057a (dostęp 15 października 2019). 
rozwiązanie umowy najmu mieszkania. Gdyby Bartosz Jóźwiak szybko odniósł się do zarzutów i rozwiązał problem umowy, kryzys trwałby krócej i miałby bardziej ograniczony zasięg.

\section{Agresja (J. Kuźniar)}

Kryzys wizerunkowy Jarosław Kuźniara był wynikiem wywiadu, którego dziennikarz i prezenter udzielił dwutygodnikowi „Grazia”, opublikowanego w wydaniu z 16 marca 2015 roku. Był to więc typowy kryzys spowodowany niefortunną komunikacją. W wywiadzie tym dziennikarz i prezenter TVN chciał prawdopodobnie zareklamować swoją nową aktywność, a mianowicie własne biuro turystyczne Go For World, oferujące wycieczki do egzotycznych miejsc. Chcąc się uwiarygodnić jako doświadczony podróżnik, podzielił się on tam receptą na podróżowanie z dziećmi:

Na podróż z dzieckiem wcale nie jest trudno się spakować, nie trzeba brać wanienek, krzesełek i bóg wie czego jeszcze. Fotelik samochodowy? Nie ma sensu. Do Kanady i USA nie braliśmy żadnych gadżetów. Pojechaliśmy do Walmartu, kupiliśmy wszystko, co było nam potrzebne, a pod koniec podróży wszystko oddaliśmy, mówiąc, że nam nie pasowało. I już. ${ }^{40}$

Ironicznie zabrzmiał cytat z wypowiedzi Jarosława Kuźniara, umieszczony na okładce pisma jako zapowiedź wywiadu: „Życie w mediach może się skończyć w sekundę. Jeśli kogoś oceniasz, sam musisz być krystalicznie czysty" ${ }^{\prime 4}$.

Sprawa wywołała kontrowersje, zachowanie Kuźniara, reklamującego nadużywanie reguł obowiązujących $\mathrm{w}$ firmie WalMart (i przedstawiającego to jako dowód sprytu, coś, czym ten chciał się szczególnie pochwalić) uznano za niestosowne i na dziennikarza wylała się fala niechęci internautów.

Reakcją na to było oświadczenie, jakie Jarosław Kuźniar umieścił na swoim blogu:

- Zasypiam na końcu świata z głową pełną przeoranych twarzy. Ludzi szarych, wymiętych, zmęczonych, pachnących smutkiem, tytoniem i alkoholem. Od ciebie zależy, ile tego do siebie dopuścisz. Po ilu kilometrach pękniesz? 2000, 3000, 9000 ? Kolej transsyberyjska zwalnia myślenie, ocenianie innych, uczy pokory, dystansu,

${ }^{40}$ Grazia, nr 6/2015, 19 marca 2015, s. 32.

${ }^{41}$ Tamże, s. 1. 
prostszego świata. Jeśli chcesz wytrwać w tej bardzo monotonnej podróży silny, musisz lekceważyć smutek większości wschodnich pasażerów. Niezwykle cenne doświadczenie w dniu, w którym jad internetowych analfabetów znów bulgocze. Spływacie po mnie. ${ }^{42}$

W tej wypowiedzi nie tylko zabrakło autorefleksji i odniesienia się do zarzutów. Jej głównym przesłaniem była niechęć, a właściwie agresja wobec tych, którzy krytykowali zachowanie Kuźniara.

Taka reakcja tylko zaogniła sprawę, niechęć wobec dziennikarza wzrosła, w internecie zaroiło się od memów, piętnujących skąpstwo Jarosława Kuźniara, powstał nawet hashtag \#sekretykuzniara, gromadzący memy, których głównym wątkiem były rozmaite, wywołujące zażenowanie, sposoby oszczędzania ${ }^{43}$ :

Kryzys został przez błędy komunikacyjne zintensyfikowany i wpłynął negatywnie na wizerunek zawodowy i osobisty dziennikarza (nazywanego potem w internecie „Królem obciachu”, oraz „Pierwszym Polakiem Cebulakiem”, w nawiązaniu do pogardliwego określenia, którym prezenter opisywał osoby niestosownie zachowujące się w podróży, np. jedzące w samolocie domową kanapkę z jajkiem), prawdopodobnie ograniczając też liczbę klientów reklamowanego w wywiadzie biura podróży.

Nieskuteczna była też późniejsza próba załagodzenia kryzysu, opierająca się na interesującym skądinąd pomyśle zagospodarowania hashtagu. Jarosław Kuźniar w krótkim, niespełna minutowym filmiku zaproponował, by pod adresem www.sekretykuzniara.com dzielić się pomysłami na oszczędne podróżowanie, internauci mieli wybierać najlepsze z nich, a Jarosław Kuźniar obiecał zadbać o nagrody:

Niech to będzie miejsce, w którym będziecie mogli zostawiać własne pomysły na to, jak ułatwiać sobie podróż, nie oszukiwać nikogo, bo nie o to chodziło, nie okłamywać nikogo, bo nie o to chodziło, ale w jaki sposób w podróży ułatwić sobie życie, szczególnie jeżeli nie jesteście sami i macie na głowie współtowarzyszy ${ }^{44}$.

${ }^{42}$ https://www.wirtualnemedia.pl/artykul/po-niefortunnej-wypowiedzi-jaroslaw-kuz niar-antybohaterem-rekordowej-serii-wpisow-na-twitterze\#; https://www.fakt.pl/kobieta/ plotki/kuzniar-odpowiada-internautom/e05epfx (dostęp 15 października 2019).

${ }^{43}$ https://demotywatory.pl/4474805/Jaroslaw-Kuzniar (dostęp 15 października 2019).

${ }^{44} \mathrm{http}: / /$ admonkey.pl/s ekretykuzniara-com-jaroslaw-kuzniar-przekuwa-w-atutwpadke-z-walmartem/ (dostęp 15 października 2019). 
W tej wypowiedzi można odnaleźć próbę odniesienia się do zarzutów, wprawdzie już bez agresji, lecz także bez wyrażenia skruchy i zauważenia popełnionych błędów. Pomysł strony nie wypalił, prawdopodobnie nie było chętnych do udziału w konkursie. Szkody wynikające z niewłaściwej komunikacji na początku kryzysu zostały z czasem zredukowane na skutek późniejszych licznych aktywności medialnych Jarosława Kuźniara, przykrywających negatywne treści, będące pokłosiem kryzysu ${ }^{45}$, z pewnością jednak inna reakcja na początku kryzysu mogłaby znacznie ograniczyć jego zasięg i skutki.

\section{Brak empatii: E. Bieńkowska}

20 stycznia 2014 roku doszło do awarii kolei, spowodowanej oblodzeniem sieci trakcyjnej, co spowodowało wielogodzinne opóźnienia. Pasażerowie spędzili długie godziny w zamarzniętych pociągach. Wywołało to ogromne zainteresowanie mediów, które publikowały m.in. szokujące zdjęcia zamarzniętych toalet. Wicepremierem i ministrem infrastruktury była wówczas Elżbieta Bieńkowska, która tego dnia wieczorem przyjęła zaproszenie do programu „Fakty po faktach” w TVN. Odnosząc się do sytuacji na kolei, Elżbieta Bieńkowska powiedziała:

Pasażerom to można tylko powiedzieć jakby: sorry, mamy taki klimat, no niestety, natomiast panu mogę powiedzieć i widzom, że wyjechało dzisiaj na tory 4000 pociągów i dwa utknęły z powodu oblodzenia sieci. Na $4000-2$. Nic nie poradzimy i wszędzie to się zdarza, natomiast PKP Intercity zrobiło wszystko, żeby tych pasażerów tam zabezpieczyć przez prawie cały dzień, bo oni stali bardzo długo w tych pociągach, no żeby to się skończyło jak się skończyło tzn. dojazdem do stacji. To nie była jakaś niesłychanie dramatyczna sytuacja. Oczywiście można to pokazywać w telewizji tych kilka osób w pociągach, kilkanaście czy kilkadziesiąt. Ale jeszcze raz powiem: 4000 pociągów, dwa... (...) Ja wiem, że to może nie jest zbyt medialne i telewizyjne. Ale prawie każdy człowiek w Polsce, i pan i ja, zdajemy sobie sprawę, że zima w Polsce jest, i że jak zima w Polsce jest, to czasami się zdarzy, że coś $(\ldots)^{46}$

Wypowiedź ta bagatelizowała problem pasażerów w zamarzniętych pociągach. Odwoływała się do zdrowego rozsądku i poprzez złożenie odpowiedzialności

${ }^{45}$ Cztery lata po kryzysie temat ten stał się praktycznie niewidoczny podczas wyszukiwania w Google przez nazwisko dziennikarza, wypowiedź nie pojawia się też w Wikicytatach, można więc mówić o zneutralizowaniu kryzysu.

${ }^{46}$ https://www.tvn24.pl/wiadomosci-z-kraju,3/mroz-zatrzymal-pociagi-sorry-mamy-taki-klimat,389583.html (dostęp 15 października 2019). 
za problemy kolei na klimat miała pewnie w zamyśle służyć uspokojeniu nastrojów. Jednocześnie zabrakło jakiejkolwiek formy przeprosin, czy współczucia, czego prawdopodobnie oczekiwali odbiorcy. Elżbieta Bieńkowska wykazała się więc radykalnym brakiem empatii. Wypowiedź zawierała ponadto charakterystyczną i przez to nośną frazę „sorry, taki mamy klimat”, która streszczała trafnie jej linię argumentacji, brzmiącej arogancko i lekceważąco, odbieranej nawet jako szyderstwa ze zmarzniętych pasażerów ${ }^{47}$. Zdanie to trafiło do licznych komentarzy oraz memów, wyśmiewających zachowanie Elżbiety Bieńkowskiej ${ }^{48}$ a z czasem także do języka potocznego, jako „skrzydlate słowa” (,sorry, taki mamy klimat” - musisz się z tym pogodzić, nikt się nie będzie nad tobą użalał, tak po prostu jest").

Niefortunne tłumaczenie spowodowało spadek poparcia dla Platformy Obywatelskiej o 4 punkty procentowe, co było bardzo wymierną stratą - wizerunkowym kosztem niewłaściwej komunikacji kryzysowej ${ }^{49}$.

\section{Niespójność komunikatu: R. Petru}

Kryzys związany z osobą Ryszarda Petru, ówczesnego szefa partii Nowoczesna, związany z jego sylwestrowym wyjazdem na Maderę, rozegrał się na przełomie 2016 i 2017 roku. Od grudnia trwał wówczas protest partii opozycyjnych, okupujących salę sejmową na znak sprzeciwu wobec zmian, wprowadzanych przez rząd Prawa i Sprawiedliwości. Opozycja, by podkreślić powagę sytuacji, używała bardzo ostrej retoryki („upadek demokracji” itp.). Petru, jako jeden z liderów opozycji również protestował, w pewnym momencie jednak zniknął i nie był obecny w przestrzeni publicznej aż do momentu, kiedy opublikowano na Twitterze zdjęcie z samolotu, przedstawiające siedzących obok siebie Ryszarda Petru i wpatrzoną w niego Joannę Schmidt, jego partyjną koleżankę. Poza wskazywała na intymność i została odebrana jako ujawnienie romansu między Petru a Schmidt ${ }^{50}$. Przy czym wiadomo było, że Ryszard Petru miał żonę i dwójkę dzieci,

${ }^{47}$ https://www.se.pl/wiadomosci/polska/bienkowska-szydzi-ze-zmarznietychpasazerow-aa-BiN3-rs9E-J2xx.html (dostęp 15 października 2019).

${ }^{48}$ https://natemat.pl/89287,elzbieta-bienkowska-o-paralizu-kolei-sorry-taki-mamy-kli mat-internet-bezlitosny-dla-wicepremier (dostęp 15 października 2019).

${ }^{49}$ https://www.rp.pl/artykul/1082153-Platforma-placi-za-Bienkowska.html (dostęp 15 października 2019).

${ }^{50}$ https://polskatimes.pl/ryszard-petru-i-joanna-schmidt-relaksuja-sie-na-maderzepodczas-protestu-opozycji-w-sejmie/ar/11648468 (dostęp 15 października 2019). 
zaś Schmidt męża i trójkę dzieci (jak się potem okazało była już wówczas w separacji z mężem).

Sprawa została nagłośniona w poniedziałek 2 stycznia 2017. Tego samego dnia na portalu 300polityka ukazał się wywiad z Ryszardem Petru, przeprowadzony w czwartek przed Sylwestrem, w którym szef Nowoczesnej oświadczył, że politykom nie wypada wyjeżdżać na wypoczynek dopóki trwa okupacja Sali Plenarnej, aż do 11 stycznia - chyba, że na 2 dni ${ }^{51}$.

Sprawa stała się tematem dnia, Ryszard Petru był nieuchwytny, nie odbierał telefonu. Jedynym komunikatem z jego strony był sms do RMF FM: „Były ustalone dyżury. Ja byłem $w$ Wigilię". 0 godzinie 10.00 Katarzyna Lubnauer, wiceprzewodnicząca Nowoczesnej, powiedziała: „Nie wiem, gdzie teraz jest Ryszard Petru. Trudno jest mi to skomentować, bo nie wiem, co robił”. 013.00 Lubnauer oświadczyła: „To był wyjazd wcześniej zaplanowany”. Na pytania dziennikarzy, czy był to wyjazd służbowy czy prywatny odpowiedziała: „W ważnych sprawach partyjnych, nazwijmy to". Dziennikarze dopytywali: jakie sprawy partyjne były załatwiane? „To już akurat sprawy wewnętrzne partii” - odparła Lubnauer ${ }^{52}$.

3 stycznia 2016 pojawił się w mediach Ryszard Petru, który oświadczył:

Ta nieobecność w ciągu kilku ostatnich dni była zaplanowana. Przypomnę byłem na Wigilię i 30 grudnia również. Następnego dnia po Wigilii byłem też chwilę na proteście w Sejmie, w związku z tym to było wcześniej zaplanowane. Przyznam, że jest to niezręczność. Że jednak przewodniczący powinien być. Druga kwestia jest taka, że wyjazd miał charakter prywatny, był finansowany z pieniędzy prywatnych, nie było tam żadnej złotówki z pieniędzy publicznych, ani partyjnych. Chcę odpowiedzieć na wszelkie pytania dotyczące kwestii politycznych, nie chcę natomiast odpowiadać na żadne pytania dotyczące kwestii nie związanych z polityką, czyli prywatnych.

Petru zauważył niezręczność sytuacji (wyjazd w czasie protestu), jednak nie były to przeprosiny czy ubolewanie z tego powodu. Skupił się na kwestiach finansowych, odpierając możliwy zarzut o finansowaniu prywatnego wyjazdu z pieniędzy partyjnych, pominął natomiast wątek obyczajowy i sprawę domniemanego

${ }^{51}$ http://300polityka.pl/news /2017/01/02/nie-chce-byc-koniunkturalny-okluczowym-2017-300polityka-rozmawia-z-ryszardem-petru/ (dostęp 15 października 2019).

${ }^{52}$ https://www.tvn24.pl/wiadomosci-z-kraju,3/ryszard-petru-wjechal-za-granicenowoczesna-tlumaczy,703930.html (dostęp 15 października 2019). 
wówczas (a potwierdzonego później) związku z Joanną Schmidt, który znacznie bardziej interesował opinię publiczną.

Większym kłopotem było jednak co innego: sprzeczność jego wyjaśnień (wyjazd prywatny, finansowany z prywatnych pieniędzy) z tym co mówiła dzień wcześniej Katarzyna Lubnauer (wyjazd służbowy).

Brak koordynacji komunikatów kryzysowych wpłynął negatywnie na wizerunek partii, podważył jej wiarygodność. Zdjęcie Petru i Schmidt stało się hitem, przerabiano je w licznych memach a nawet filmach publikowanych w Youtube ${ }^{53}$. Dodatkowo brak komentarza na temat relacji Ryszarda Petru i Joanny Schmidt, która tak angażowała opinię publiczną, jeszcze zwiększyła atrakcyjność tematu i wywołała falę publikacji. Ucierpiał wizerunek Petru jako przywódcy partii, jednego z głównych polityków opozycji. Zaprezentował się on jako człowiek, dla którego wyjazd z kochanką jest ważniejszy, niż sprawy publiczne, nawet w sytuacji przedstawianej jako „zagrożenie demokracji”.

Przynajmniej teoretycznie sprawy mogły potoczyć się inaczej. Szybka i spójna komunikacja mogłaby ograniczyć rozmiary kryzysu, a oficjalne ujawnienie romansu (do czego i tak doszło po pewnym czasie) mogłoby uatrakcyjnić wizerunek Ryszarda Petru. Szef Nowoczesnej, wcześniej postrzegany jako technokrata i człowiek nieco sztywny (lub dla odmiany zabawny, autor wielu niefortunnych wypowiedzi), mógłby przy tej okazji pokazać „ludzką twarz” i wzbudzić emocje a może i sympatię wyborców, dając się poznać jako mężczyzna podążający za uczuciami, zdolny do porywów serca. Tymczasem brak komunikacji i wydanie komunikatów nieskoordynowanych ze sobą (improwizowana i prawdopodobnie nie skonsultowana z Ryszardem Petru narracja Katarzyny Lubnauer o „wyjeździe służbowym") spotęgowały rozmiary kryzysu i długofalowo spowodowały utratę przez Petru pozycji szefa Nowoczesnej i marginalizację Ryszarda Petru jako polityka.

\section{Wbrew oczekiwaniom społecznym: B. Szydło}

Kryzys związany z premier a potem wicepremier Beatą Szydło był związany z przyznaniem nagród dla członków rządu za 2017 rok. 21 ministrów otrzymało

${ }^{53}$ Np. przeróbka przeboju zespołu Akcent „Przez twe oczy zielone”: https://www.youtube.com/watch?v=dWZhBxMDXHc, prawie 466 tysięcy udostępnień (dostęp 15 października 2019). 
nagrody od 65100 do 82100 zł, 12 ministrów w KPRM otrzymało od 36900 do 59400 zł, zaś sama premier Szydło 65100 zł (w tym wypadku była osobą, która sama sobie przyznała nagrodę jako premier). Sprawa została ujawniona i nagłośniona przez media, wywołując oburzenie opinii publicznej: krytykowano zarówno sam fakt przyznawania sobie nagród przez członków rządu, jak i ich wysokość. Spowodowało to poważny kryzys rządu: część ministrów zaczęło zwracać nagrody, inni przeznaczyli je na cele charytatywne. Finalnie wszyscy zostali zmuszeni do przekazania pieniędzy na rzecz Caritasu. Nim to się stało, niektórzy bronili nagród, argumentując, że należą się im one za ciężką i efektywną pracę, tym bardziej, że wynagrodzenia członków rządu są relatywnie niskie w stosunku do zakresu obowiązków i odpowiedzialności.

Nagród postanowiła bronić Beata Szydło, która wcześniej, jeszcze jako premier, podjęła decyzje o ich przyznaniu (w momencie ujawnienia sprawy była już wicepremierem w rządzie Mateusza Morawieckiego). Sprawa ta była tematem wystąpienia sejmowego 22 marca 2018. Na początku drugiej połowy wystąpienia (6'12" z 10'28') Beata Szydło powiedziała:

(...) Tak, rzeczywiście, ministrowie i wiceministrowie w rządzie Prawa i Sprawiedliwości otrzymywali nagrody za ciężką i uczciwą pracę i te pieniądze im się po prostu należały. To były nagrody oficjalne. Nagrody, które zostały przyznane $\mathrm{w}$ ramach budżetu uchwalonego $\mathrm{w}$ tej izbie, a nie zegarki od kolegów biznesmenów. Ci ludzie ciężko pracowali i pracują na to, żeby wszyscy Polacy mogli cieszyć się z rozwoju Polski, a nie wybrane grupy interesu. Chcemy dalszego rozwoju, chcemy żeby Polska nadal budowała swoją silną pozycję na świecie i w Europie. Myślimy o tych wyzwaniach, które przed nami. Naszym błędem, i tu zwracam się do naszych rodaków, do Polaków, było, że na początku kadencji nie porozmawialiśmy z Państwem o tym jak należy wynagradzać uczciwe pracujących i ciężko pracujących urzędników. Ale mam nadzieję, wierzę w to głęboko, że ten temat zostanie w tej chwili uporządkowany i zamknięty. ${ }^{54}$

Wystąpienie zostało źle odebrane przez opinię publiczną. Do tytułów przebiła się fraza „nagrody ministrom się należały”55, czy „ministrom rządu PiS te

${ }^{54}$ https://www.youtube.com/watch?v=3hASj19ZuHs (dostęp 15 października 2019).

${ }^{55}$ Np. dziennik Rzeczpospolita: https://www.rp.pl/Rzad-PiS/180329721-Beata-SzydloNagrody-ministrom-sie-nalezaly-Za-ciezka-uczciwa-prace.html (dostęp 15 października 2019). 
pieniądze się po prostu należały ${ }^{56}$. Wobec ogólnej niechęci do polityków komunikat, iż „nagrody się po prostu należały” musiał wzbudzać niechęć, zwłaszcza w zestawieniu z sumami, relatywnie wysokimi w stosunku do przeciętnego wynagrodzenia, wyższymi niż roczne dochody większości obywateli. Argument, że nagrody były oficjalnie przyznane i legalne też nie trafił do opinii publicznej. Potwierdza to nie wymienioną na początku, lecz znaną powszechnie regułę komunikacji kryzysowej: ważniejsza od samej zgodności z prawem jest często ocena moralna - nie wystarczy przestrzegać przepisów, trzeba też liczyć się z osądem opinii publicznej, opierającym się na potocznym rozumieniu stosowności i etyki postępowania, a nie na kodeksach.

Być może znaczenie miało też samo słowo „nagroda” kojarzące się z wyjątkowymi osiągnięciami, wykraczającymi poza dobre wywiązywanie się z obowiązków. W potocznym rozumieniu za pracę otrzymuje się wynagrodzenie, zaś nagroda musi być szczególnie uzasadniona, tym bardziej gdy jest taka wysoka.

Na krytyczny odbiór omawianego wystąpienia złożyła się też forma wypowiedzi. Towarzyszył mu zgiełk na sali sejmowej, wystąpienie było przerywane zarówno okrzykami posłów koalicji, skandujących „Beata, Beata!”, jak i opozycji: „oddaj kasę!”. W rezultacie Beata Szydło, zwracając się do atakującej ją opozycji, mówiła podniesionym głosem, agresywnym tonem, mimika wskazywała na negatywne emocje ${ }^{57}$.

Jak się wydaje, mogło to mieć głębszy podtekst. Beata Szydło, broniąc nagród i wyliczając dokonania swojego rządu uzasadniające ich przyznanie, broniła w istocie swoich osiągnięć jako premiera, odwołanego kilka miesięcy wcześniej z tej funkcji w okolicznościach nie do końca zrozumiałych dla opinii publicznej, bez wyraźnego, konkretnego powodu.

Ogólnie można powiedzieć, że racjonalna narracja na temat nagród, wiążąca je z zasługami urzędników w realizacji programu rządu, wprowadzającego rozwiązania korzystne dla obywateli, zderzyła się frontalnie z krytyczną wobec nagród narracją tabloidów („politycy rozdają sobie pieniądze, myśląc, że one im się po prostu należą"), podzielaną przez dużą część opinii publicznej.

${ }^{56}$ TVN24: https://www.tvn24.pl/wiadomosci-z-kraju,3/beata-szydlo-o-nagrodach-dla-ministrow-rzadu,824216.html (dostęp 15 października 2019).

${ }^{57}$ https://www.youtube.com/watch?v=3hASj19ZuHs (dostęp 15 października 2019). 
W wystąpieniu Beaty Szydło pojawiło się wprawdzie coś w rodzaju skruchy (przyznanie się do błędu), jednak nie w kontekście faktu przyznania nagród (czego być może opinia publiczna oczekiwała), lecz w kwestii podniesienia tematu wynagrodzeń urzędników.

W efekcie rząd Prawa i Sprawiedliwości odnotował duży spadek w sondażach, sięgający $12 \%{ }^{58}$, a echa sprawy nagród, mimo ich oddania, pojawiały się jeszcze dużo później.

\section{PRZYCZYNY ZAKŁÓCEŃ KOMUNIKACJI KRYZYSOWEJ}

Analizując te i wiele innych przypadków, nietrudno zauważyć, że komunikacja kryzysowa wymaga bardzo dużej rozwagi. Z jednej strony trzeba działać szybko, z drugiej - działanie zbyt spontaniczne, nieprzemyślane też może być przyczyną kłopotów, zwłaszcza gdy komunikacji towarzyszą emocje czy agresja (Kamil Durczok, Jarosław Kuźniar). Nie można zbyt wcześnie przyznawać się do błędu, ale też nie warto brnąć w obronę własnego stanowiska wbrew faktom czy wbrew opinii publicznej, gdyż tylko potęguje to straty wizerunkowe związane z kryzysem (Kamil Durczok, Elżbieta Bieńkowska, Beata Szydło). Często wcześniejsze wycofanie się i podjęcie jakiejś decyzji spontanicznie, nie pod presją opinii publicznej mogłoby znacznie ograniczyć rozmiary kryzysu (Bartosz Jóźwiak, Beata Szydło). Ważną sprawą jest wreszcie koordynacja komunikatów, ustalenie od początku narracji, która jest zgodna z prawdą i jednocześnie możliwa od obrony (Ryszard Petru).

\section{Nie można zbyt wcześnie przyznawać się do błędu, ale też nie warto brnąć w obronę własnego stanowiska wbrew faktom czy wbrew opinii publicznej, gdyż tylko potęguje to straty wizerunkowe związane z kryzysem.}

${ }^{58}$ https://fakty.tvn24.pl/sondaze-dla-faktow-tvn-i-tvn24,106/duzy-spadek-poparciadla-pis-sondaz-dla-faktow-tvn-i-tvn24,825496.html (dostęp 15 października 2019). 
W wielu wypadkach źródłem perturbacji jest brak empatii i uwzględnienia optyki zwykłego odbiorcy, co skutkuje rozmijaniem się komunikatów kryzysowych z oczekiwaniami opinii publicznej (Kamil Durczok, Elżbieta Bieńkowska, Bartosz Jóźwiak, Ryszard Petru, Beata Szydło). Poważnym problemem jest brak odniesienia się do zarzutów, wysyłanie komunikatów w pewien sposób nierelewantnych, nie w dialogu z mediami czy zwykłymi odbiorcami (Jarosław Kuźniar, Bartosz Jóźwiak, Elżbieta Bieńkowska, Ryszard Petru) i chęć obrony własnego stanowiska za wszelką cenę (Kamil Durczok, Beata Szydło).

Jak pokazały powyższe analizy liczy się też kontrola nad formą komunikatu. Nie tylko unikanie emocji i agresji, lecz także używanie odpowiednich formuł językowych, gdyż często to niewłaściwie używane słowa mogą zaogniać sytuację: czasem sama forma wypowiedzi wywołuje negatywne reakcje odbiorców (Jarosław Kuźniar, Elżbieta Bieńkowska, Beata Szydło).

Rozważając przyczyny pojawienia się podobnych zakłóceń w komunikacji kryzysowej, należy wskazać na presję czasu i czynniki psychologiczne. Presja czasu w powiązaniu z elementem zaskoczenia utrudnia podejmowanie racjonalnych decyzji, powodując z jednej strony paraliż (i zwlekanie z komunikacją), a z drugiej skłonność do wysyłania opinii publicznej komunikatów nieprzemyślanych, niesprawdzonych, formułowanych pod wpływem emocji. Osobnym czynnikiem utrudniającym właściwą reakcję jest psychologia kogoś, kto nagle znajduje się w centrum uwagi mediów. Sytuacja kryzysowa może powodować pobudzenie, stany lękowe, obawy, poczucie winy i bezradności ${ }^{59}$. Związana z tym presja, poczucie bycia atakowanym prowadzi niekiedy do uporczywej obrony własnego stanowiska - także wbrew rozsądkowi, wbrew faktom, a zdarza się, że i w agresywnej formie. Postawa taka może być nazywana „mentalnością oblężenia”60.

Niekiedy tłem takiego zachowania jest fakt odkrycia przez media wstydliwych szczegółów z życia osób publicznych czy instytucji. Kryzys wiąże się z dezintymizacją: na światło dzienne wychodzą kłopotliwie wizerunkowo szczegóły życia osobistego czy aktywności zawodowej (K. Durczok, B. Jóźwiak, R. Petru, w pewnym sensie także J. Kuźniar). Osoba, której dotyczy kryzys liczy niekiedy na to, że jej działania niezgodne z regułami społecznymi pozostaną ukryte, jeśli nie

${ }^{59}$ D. Tworzydło, Zarządzanie w kryzysie wizerunkowym, Warszawa 2019, s. 54.

${ }^{60}$ R. Bridgemann, Bariery organizacyjne przy zarządzaniu kryzysem i public affairs, w: Komunikacja kryzysowa, (red.) P.F. Anthonissen, Warszawa 2019, s. 194-195. 
będzie się o nich mówić, albo kiedy się im zaprzeczy - nawet wtedy, kiedy można przypuszczać, że takie zaprzeczanie tylko pogarsza sprawę. Publiczne przyznanie się do winy i przeproszenie poszkodowanych albo opinii publicznej (które zwykle pomaga w wygaszeniu kryzysu) wiąże się z dużym kosztem psychicznym; obawa przed kompromitacją prowadzi często do mijania się z prawdą (K. Durczok), zaprzeczania nawet temu co już zostało udowodnione (B. Jóźwiak), a czasem do agresji (J. Kuźniar).

\section{REKOMENDACJE DOTYCZĄCE ROZWIĄZYWANIA SYTUACJI KRYZYSOWYCH}

Opisane wyżej przyczyny zakłóceń w komunikacji kryzysowej są argumentem na rzecz korzystania w takich sytuacjach z profesjonalnego wsparcia ze strony konsultantów i agencji PR, których rolą jest trzeźwa i pozbawiona emocji ocena sytu-

\section{Na kryzysie można zyskać, ale tylko wtedy, gdy komunikacja kryzysowa firmy, organizacji czy osoby publicznej jest zgodna z regułami, przemyślana w treści i w formie.}

acji, opracowanie optymalnego w danej sytuacji przekazu i przygotowanie osoby której dotyczy kryzys (lub przedstawicieli instytucji, której wizerunek jest zagrożony) do kontaktów z mediami. Barierami, które to utrudniają, a niekiedy wręcz uniemożliwiają mogą być: 1 . koszty (nie każdego stać na takie usługi), 2. brak zaufania do konsultantów (którym trzeba szczerze powiedzieć jakie są fakty, aby mogli opracować strategię komunikacyjną - niektórzy obawiają się ujawnienia wstydliwych szczegółów), 3. przekonanie o własnych kompetencjach w zakresie komunikacji, wystarczających by sobie samemu poradzić (nieprzypadkowo dwa z opisanych kryzysów dotyczą bardzo doświadczonych dziennikarzy), albo odwrotnie - 4. brak dostatecznego obycia z mediami i zrozumienia natury zagrożeń związanych z niewłaściwą komunikacją (E. Bieńkowska, R. Petru). Stąd zalecenia, by wcześniej przygotowywać osoby, które w hipotetycznej sytuacji kryzysowej 
będą zmuszone udzielać wypowiedzi mediom poprzez szkolenia kryzysowe ${ }^{61}$; szkolenia takie mogą oswajać z presją ze strony mediów, redukować dyskomfort psychiczny czasie realnego kryzysu i tym samym ułatwiać skuteczną komunikację. A przy okazji uświadamiać potrzebę korzystania z profesjonalnego wsparcia, gdy dojdzie do kryzysu - ponieważ osoba, która jest w środku często nie umie sama właściwie ocenić sytuacji i wybrać optymalnej strategii komunikacyjnej.

Jak zaznaczono na wstępie, na kryzysie można zyskać, ale tylko wtedy, gdy komunikacja kryzysowa firmy, organizacji czy osoby publicznej jest zgodna z regułami, przemyślana w treści i w formie. Wychodząc od analizy przypadków zakłóceń komunikacji kryzysowej omawianych w niniejszym artykule można się pokusić o sformułowanie postulatów wobec takiej komunikacji. Można je zawrzeć w kilku słowach-kluczach: prawda, empatia, dialog, elastyczność, koordynacja, opanowanie. Pominięcie któregoś z tych czynników z reguły prowadzi do eskalacji kryzysu.

\section{BIBLIOGRAFIA}

Bridgemann R., Bariery organizacyjne przy zarządzaniu kryzysem i public affairs, w: Komunikacja kryzysowa, (red.) P.F. Anthonissen, Warszawa 2019, s. 188-195.

Cornelissen J., Komunikacja korporacyjna, Warszawa 2012.

Hyslop S., W jaki sposób zarząd może pogorszyć sytuację, w: Komunikacja kryzysowa, (red.) Anthonissen P.F., Warszawa 2019, s. 152-161.

Kaczmarek-Śliwińska M., Public Relations w zarzq̨dzaniu sytuacjami kryzysowymi w organizacji. Sztuka komunikowania się, Warszawa 2015.

Kamiński L., Komunikacja korporacyjna a biznes, Bydgoszcz-Warszawa 2007.

Kopeć-Ziemczyk K., Jak skutecznie radzić sobie z kryzysem wizerunkowym $w$ mediach społecznościowych - przykład Tigera, „Naukowy Przegląd Dziennikarski” 1/2018, s. 35-54.

Regester M., Larkin J., Zarzq̨dzanie kryzysem, Warszawa 2005.

Smektała T., Public relations w sytuacjach kryzysowych przedsiębiorstw, Wrocław 2005.

Tworzydło D., Procedura zarzq̨dzania w kryzysie wizerunkowym $w$ mediach - przeciwdziatanie, reagowanie oraz odzyskiwanie wizerunkowych korzyści, „Studia Medioznawcze" 3 (70)/2017, s. 77-90.

Tworzydło D., Public Relations praktycznie, Rzeszów 2017.

${ }^{61} \mathrm{~Np}$. S. Hyslop, W jaki sposób zarząd może pogorszyć sytuację, w: Komunikacja kryzyso$w a$, (red.) P.F. Anthonissen, Warszawa 2019, s. 152-161. 
Tworzydło D., Skuteczne zarządzanie w kryzysie wizerunkowym na przykładzie marki Tiger, „Studia Medioznawcze” 1 (76)/2019, s. 1-14.

Tworzydło D., Zarzqdzanie w kryzysie wizerunkowym, Warszawa 2019.

Walas-Trębacz J. , Ziarko J., Podstawy zarzadzania kryzysowego, Cz. 2, Zarządzanie kryzysowe w przedsiębiorstwie, Kraków 2011.

\section{Biogram autora}

Dr hab. Marek Kochan, prof. Uniwersytetu SWPS. Pracuje w Katedrze Dziennikarstwa Wydziału Nauk Humanistycznych i Społecznych Uniwersytetu SWPS. Zajmuje się naukowo i praktycznie m.in. retoryką i erystyką, wizerunkiem, komunikacją biznesową i kryzysową, językiem mediów, debatami. Autor kilkudziesięciu prac naukowych, w tym książek „Pojedynek na słowa. Techniki erystyczne w publicznych sporach”, „Slogany w reklamie i polityce”. Redaktor i współautor tomu „Sztuka debaty”.

e-mail: mkochan@swps.edu.pl, https://orcid.org/0000-0001-9502-6171 


\title{
Zofia Sawicka
}

\author{
Wyższa Szkoła Informatyki i Zarządzania w Rzeszowie
}

\section{Czy dżihad może być cool? Nowe media w służbie zbrojnego dżihadu}

\section{Can jihad be cool? New media in the service of armed jihad}

\begin{abstract}
STRESZCZENIE
Celem artykułu jest prezentacja zjawisk cool/pop/street jihadu jako efektu oddziaływania nowych mediów. W przeprowadzonej analizie autorka ukazuje związek pomiędzy rosnącą popularnością mediów społecznościowych a możliwością radykalizacji młodych muzułmanów na całym świecie. Opisując czynniki rozwoju e-dżihadu jednocześnie odnosi je do cech „pokolenia millenialsów”, wskazując na przyczyny atrakcyjności i skuteczności przedstawiania dżihadu jako modnego stylu życia bądź subkultury. Jednocześnie na podstawie przeprowadzonych badań dokonuje systematyzacji opisywanych zjawisk różnicując je według celów i cech audytorium, do których są skierowane. Ukazuje mechanizm przekształcający banalne życie młodych ludzi w celebrycką przygodę, którą za pomocą nowych mediów mogą zaprezentować szerokiej widowni. Według autorki mechanizm ten jest największą siłą i jednocześnie najbardziej niebezpiecznym elementem opisywanych zjawisk, który doprowadza do radykalizacji części środowisk młodych muzułmanów na całym świecie.
\end{abstract}

\section{SŁOWA KLUCZOWE:}

cool jihad, popkultura, media społecznościowe, terroryzm

\begin{abstract}
The aim of the article is to present the phenomenon of cool / pop / street jihad as the effect of the new media. In the conducted analysis, the author shows the relationship between the growing popularity of social media and the possibility of the radicalization of young Muslims around the world. Describing the reasons for the development of e-jihad, at the same time refers them to the features of the millennial generation, pointing to the reasons for the attractiveness and effectiveness of portraying jihad as a fashionable lifestyle or subculture. Based on the conducted research, the author systematizes the described phenomena by differentiating them according to the objectives and characteristics of the auditorium to which they are addressed. The author shows the mechanism transforming the banal (according to them) young people's life into a celebrity adventure, which they can present to a wide audience using social media. According to the author, this mechanism is the greatest force and at the same time the most dangerous element of the described phenomena, which leads to the radicalization the part of the young Muslims around the world.
\end{abstract}

\section{KEYWORDS:}

cool jihad, pop culture, social media, terrorism 


\section{WSTĘP}

Rozpowszechnianie ekstremistycznych, dżihadystycznych i podżegających do przemocy stron internetowych, blogów i kanałów w mediach społecznościowych nie jest nowym zjawiskiem. Rola nowych mediów w rozwoju terroryzmu na świecie została już wielokrotnie opisana ${ }^{1}$. Wszystkie cechy nowych mediów, a więc: szybkość nawiązywania i prowadzenia komunikacji na dużą odległość, ogromny zasięg geograficzny i społeczny, pojemność rozumiana jako możliwość przechowywania nieskończonej liczby danych, wierność, dokładność przekazywanych informacji, która pozwala na kontrolowanie rosnącej złożoności społeczeństw
Nowe media pozwoliły ugrupowaniom terrorystycznym i radykalnym organizacjom islamistycznym na coś znacznie więcej niż tylko usprawnienie komunikacji, stały się bowiem doskonałym narzędziem do głoszenia własnej ideologii i manipulacji młodymi ludźmi, którzy niepostrzeżenie z osób niezaangażowanych do tej pory w politykę czy religię stali się radykalnymi wyznawcami wartości głoszonych przez dane ugrupowanie, gotowymi do wprowadzenia je w czyn.

i organizacji, selektywność zarówno wiadomości, jak i adresatów oraz interaktywność ${ }^{2}$ zwiększyły komunikacyjną aktywność ugrupowań terrorystycznych.

${ }^{1}$ Zob. m.in. B.L. Nacos, Mass Mediated Terrorism, Oxford 2002; B. Bolechów, Terroryzm. Aktorzy, statyści, widownie, Warszawa 2010; G. Weimann, Terror on the Internet: The New Arena, the New Challenges, Washington, 2006; P. Seib, D. M. Janek, Global Terrorism and New Media: The Post-Al Qaeda Generation, New York 2011; G. Weimann, New Terrorism and New Media, Wilson Center, 2014, https://www.wilsoncenter.org/sites/default/files/STIP_140501_ new_terrorism_F.pdf (dostęp 10.07.2019).

${ }^{2}$ Zob. J. van Dijk, Społeczne aspekty nowych mediów, Warszawa 2010, s. 27-30. 
To właśnie grupy ekstremistyczne na całym świecie jako jedne z pierwszych doceniły potencjał nowych form komunikacji. Możliwość uniezależnienia się od mediów tradycyjnych i dziennikarskiej cenzury z punktu widzenia propagandy radykalnych ugrupowań islamistycznych w tym ugrupowań terrorystycznych stały się faktem nie do przecenienia. Jednak nowe media pozwoliły tym ugrupowaniom na coś znacznie więcej niż tylko usprawnienie komunikacji, stały się bowiem doskonałym narzędziem do głoszenia własnej ideologii i manipulacji młodymi ludźmi, którzy niepostrzeżenie z osób niezaangażowanych do tej pory w politykę czy religię stały się radykalnymi wyznawcami wartości głoszonych przez dane ugrupowanie, gotowymi do wprowadzenia je w czyn.

Najlepszym przykładem sygnalizowanego wyżej procesu są zjawiska cool/ street/pop jihadu promowane przez islamskie ugrupowania terrorystyczne oraz radykalne organizacje islamistyczne. $W$ przeprowadzonej analizie autorka ukazuje związek pomiędzy rosnącą popularnością mediów społecznościowych a możliwością radykalizacji młodych muzułmanów na całym świecie. Opisując czynniki rozwoju e-dżihadu, jednocześnie odnosi je do cech „pokolenia millenialsów”, wskazując na przyczyny atrakcyjności i skuteczności przedstawiania dżihadu jako modnego stylu życia bądź subkultury. Współcześnie - poprzez działalność ugrupowań terrorystycznych oraz za przyczyną obrazu kreowanego w mediach w świadomości światowej opinii publicznej (w tym młodych ludzi) dżihad wiąże się z ideą świętej wojny, wezwaniem do walki zbrojnej i do zabijania innych osób. Jednak za pomocą mediów społecznościowych radykalnym ugrupowaniom islamistycznym udaje się przedstawić zjawisko zbrojnego dżihadu jako świat pełen przygód połączonych z obietnicą ziemskich przyjemności. W komunikatach wysyłanych do młodzieży ukryta jest z jednej strony wizja sławy, z drugiej zaś - obietnica luksusowego, ale „cnotliwego” życia. Artykuł ukazuje mechanizm przekształcający banalne (według autorów komunikatów) życie młodych ludzi w celebrycką przygodę, którą za pomocą nowych mediów mogą zaprezentować szerokiej widowni. Według autorki mechanizm ten jest największą siłą i jednocześnie najbardziej niebezpiecznym elementem opisywanych zjawisk, który doprowadza do radykalizacji części środowisk młodych muzułmanów na całym świecie.

Wielowątkowość, wieloaspektowość oraz interdyscyplinarność badanego zagadnienia wymagały zastosowania metody badawczej, za pomocą której będzie możliwe dokonanie jak najszerszej analizy. Według autorki najlepszą metodą, która pozwoli na znalezienie odpowiedzi na podstawowe pytanie badawcze - czy 
i jak nowe media biorą udział w radykalizacji młodych muzułmanów na świecie jest krytyczna analiza dyskursu (KAD), której głównym reprezentantem i orędownikiem jest holenderski badacz Teun van Dijk. W odniesieniu do badania mediów van Dijk podkreśla, że analiza dyskursu przekazów medialnych nie może być zredukowana do badania jedynie struktur tekstowych, ponieważ pod nimi kryją się opinie, znaczenia, ideologie ${ }^{3}$. W celu pełnego wydobycia tych znaczeń konieczne jest przeprowadzenie analizy w kontekście politycznym, społecznym i kulturowym, czego też próbuje dokonać autorka w niniejszym artykule. Przeprowadzona krytyczna analiza dyskursu nowych mediów oraz analiza raportów dotyczących radykalizacji muzułmanów w Europie pokazuje, że za pomocą nowych mediów ugrupowaniom terrorystycznym i radykalnym organizacjom islamistycznym udaje się przemycić ideologię dżihadu, która dla wielu młodych muzułmanów staje się elementem popkultury i synonimem modnego stylu życia. Konsekwencją tego zjawiska jest powstanie coraz bardziej wrogo nastawionego, radykalnego i gotowego do walki pokolenia młodych muzułmanów, przede wszystkim w Europie, ale też w państwach muzułmańskich.

\section{MŁODZI GNIEWNI}

Świat muzułmański to świat ludzi młodych. Szczególnie widać to w odniesieniu do krajów arabskich. Młodzież stanowi 2/3 społeczeństw tych państw. W Jemenie, Omanie, Arabii Saudyjskiej, Jordanii, Maroku i Egipcie 50\% ludności to ludzie poniżej 25 roku życia, w pozostałych krajach arabskich pokolenie młodych stanowi od 35\% do 47\% ludności. Wśród nich 50\%-70\% stanowią bezrobotni ${ }^{4}$. Młodzi ludzie po ukończeniu studiów czy szkoły średniej nie mogą znaleźć pracy, a co za tym idzie - usamodzielnić się i uniezależnić finansowo od rodziny. Nie mogą również zawrzeć związku małżeńskiego, co w społeczeństwach zdominowanych przez islam oznacza w rezultacie brak możliwości kontaktów damsko-męskich, a to prowadzi z kolei do poczucia głębokiej frustracji. Coraz trudniej jest im pogodzić się z otaczającą rzeczywistością, a jednocześnie są bezsilni, żeby ją zmienić.

${ }^{3}$ T. van Dijk, The interdisciplinary study of news as discourse, w: A handbook of qualitative methodologies for mass communication research, K.B Jensen, N.W Jankowski, London 1991, s. 108-120.

${ }^{4}$ Arab Development Portal, Demography, 2018, http://www.arabdevelopmentportal. com/indicator/demography, (dostęp 1.06.2019). 
Przytłoczeni stanem ekonomicznym i ograniczeniami kulturowymi są łatwym celem dla wszelkiego rodzaju propagandzistów i szafarzy obietnic o lepszym życiu ${ }^{5}$. Bunt młodego pokolenia i jego narastający gniew objawił się już światu podczas Arabskiej Wiosny, która swoim zasięgiem objęła wszystkie państwa arabskie. O ile zmiany, które nastąpiły w wyniku protestów, da się zauważyć w każdym kraju, to jednak ambicje i potrzeby młodych ludzi nie zostały zaspokojone w żadnym z nich ${ }^{6}$. Rosnące rozczarowanie sytuacją polityczno-ekonomiczną sprawia, że część młodzieży zwraca się w stronę islamu - jego najbardziej radykalnej wersji. W swojej książce ISIS, wewnątrz armii terroru dziennikarze Weiss i Hassan cytują jednego z amerykańskich analityków, który zajmował się Państwem Islamskim i który twierdził, że rząd amerykański nie do końca zrozumiał na czym polega atrakcyjność tego ugrupowania dla ludzi najbardziej podatnych na jego propagandę. Dla dowiedzenia swoich racji ów analityk zakończył badania pytaniem retorycznym, które w pełni oddaje istotę działania cool jihadu: „Macie dzieci? Czy podoba im się cokolwiek umiarkowanego?"7

Jeśli chodzi o Europę Zachodnią, to według analizy instytutu Pew Research Center mniejszość muzułmańska we wszystkich krajach europejskich stanowiła w 2016 roku około 4.9\% całej populacji europejskiej. Instytut przewiduje, że do 2050 roku powiększy się ona do 11,2 \%. Liczba ta będzie uzależniona jednak od możliwości migracji do Europy. Warto zaznaczyć, że według przeprowadzonego raportu muzułmanie poniżej 30 roku życia stanowili w 2016 roku 50\% wszystkich muzułmanów w Europie, a przeciętny wiek muzułmanina wynosił 30 lat $^{8}$.

Należy jednak zaznaczyć, że liczba muzułmanów w Europie nie jest do końca znana ze względu na to, że diaspory w poszczególnych krajach składają się z wielu fal imigrantów i obejmują zarówno obywateli danego kraju, jak i imigrantów legalnych oraz nielegalnych. Ponadto w niektórych krajach wyznanie nie służy

${ }^{5}$ D. Dhillon, P. Dyer, T. Yousef, Generation in Waiting. The Unfulfilled Promise of Young People in the Middle East, Washington 2009.

${ }^{6}$ Efekt Arabskiej Wiosny w każdym z państw arabskich był inny (wpływ na to miała siła rządzących reżimów), jednak należy podkreślić, że w całym świecie arabskim była widoczna aktywność młodzieży, która organizowała się w ruchy internetowe, których działalność była kontynuowana także po ustaniu ulicznych protestów. (przyp. autorki)

${ }^{7}$ M. Weiss, H. Hassan, ISIS wewnątrz armii terroru, Warszawa 2015, s. 280.

${ }^{8} \mathrm{C}$. Hackett, 5 facts about the Muslim population in Europe, Pew Research Center, 2018 https://www.pewresearch.org/fact-tank/2017/11/29/5-facts-about-the-muslimpopulation-in-europe/ (dostęp 10.07.2019). 
bądź nie służyło jako identyfikator przy spisywaniu ludności, a zatem podane dane są zaniżone9.

Niezależnie jednak od różnic w ocenie liczebności muzułmanów w Europie Zachodniej pewne jest, że wykazuje ona stałą tendencję wzrostową. Kolejna ważna kwestia to wymiana pokoleniowa, do której doszło w diasporze muzułmańskiej - dla drugiego i trzeciego pokolenia kraj przyjmujący jest ich miejscem urodzenia. Generacje te funkcjonują w zawieszeniu pomiędzy kulturą kraju pochodzenia rodziców, a kulturą europejską kraju, w którym żyją. Zjawisko to przynosi określone konsekwencje. Z jednej strony przedstawiciele obydwu generacji w większości deklarują przywiązanie do religii i życia zgodnego z regułami islamu, z drugiej - wychowani w państwach demokratycznych, szanujących wolności obywatelskie - domagają się zastosowania tych zasad w stosunku do ich religii i obowiązków jakie z niej wynikają ${ }^{10}$.

Jednocześnie pojawił się problem tożsamości kolejnych generacji imigrantów muzułmańskich, który stanowił wypadkową braku znajomości własnych korzeni i przeszkód społecznych np. problemów w szkole, braku akceptacji społecznej, braku pracy. Większość muzułmanów w Europie Zachodniej należy do najniższych klas społecznych, winą za tę sytuację obarczając państwa, w których żyją. Napędzani frustracją i poczuciem niesprawiedliwości domagają się dla siebie coraz większych praw. 0 ile drugie i trzecie pokolenie muzułmanów przyjęło wzorce zachodniej kultury konsumpcyjnej, o tyle islam, stał się dla nich wyznacznikiem tożsamości ${ }^{11}$. Taka postawa często prowadzi do radykalizacji.

Pisząc o młodych muzułmanach w Europie czy w państwach muzułmańskich, nie wolno zapominać, że podobnie jak ich rówieśnicy na całym świecie także oni należą do „pokolenia millenialsów”, których część badaczy określa również, jako pokolenie sieci czy pokolenie Ja. Ci „cyfrowi tubylcy” traktują Internet jako naturalną przestrzeń działania, istotną na równi z rzeczywistością realną. Co więcej według Marca Prensky'ego nowe technologie nie tylko zmieniły sposób

${ }^{9}$ J. Zdanowski, Muzułmanie $w$ świecie zachodnim. Stare i nowe tożsamości, „Krakowskie Studia Międzynarodowe", numer IV, 2007.

${ }^{10}$ Zob. Z. Sawicka, Islam w Europie czy europejski islam. Kwestia wartości, w: W pułapce wielokulturowości, A. Siewierska-Chmaj (red.), Warszawa 2016, s. 53-70.

${ }^{11}$ K. Górak-Sosnowska, Muzułmanie w Europie. Dystans kulturowy, szanse asymilacji i integracji, w: Współczesna Europa w procesie zmian. Wybrane problemy, J. Polakowska-Kujawa (red.), Warszawa, s. 236-253. 
komunikowania się tej generacji, ale przede wszystkim zmieniły ich sposób myślenia i zdolność przetwarzania informacji. Pokolenie to sprawnie posługuje się obrazkami czy grafikami, tekst pisany natomiast jest przez większość trudny do zrozumienia. Wychowani na grach komputerowych, przyzwyczajeni są do szybkich osiągnięć i natychmiastowej gratyfikacji. Według Prensky’ego, by dotrzeć do przedstawicieli tego pokolenia, należy używać specyficznego języka i sposobu myślenia o świecie, który będzie odzwierciedlał zasady działania gier komputerowych czy mediów społecznościowych ${ }^{12}$.

\section{Pisząc o młodych muzułmanach w Europie czy w państwach muzułmańskich nie wolno zapominać, że podobnie jak ich rówieśnicy na całym świecie także oni należą do „pokolenia millenialsów", których część badaczy określa również, jako pokolenie sieci czy pokolenie Ja. Ci "cyfrowi tubylcy" traktują Internet jako naturalną przestrzeń działania, istotną na równi z rzeczywistością realną.}

Kolejną cechą pokolenia „cyfrowych tubylców” jest stale rosnący narcyzm. W dobie selfie i publikowania zdjęć w sieci kształtowanie własnego pozytywnego wizerunku stało się dla wielu młodych ludzi celem życia i wyznacznikiem sukcesu. Wydaje się, że nigdy wcześniej ludzie nie byli tak mocno skoncentrowani na sobie i jednocześnie nie pragnęli popularności mającej odzwierciedlenie w liczbach polubień i komentarzy na portalach społecznościowych ${ }^{13}$. Jak się wyda-

${ }^{12}$ M. Prensky, Digital Natives, Digital Immigrants, 2001, https://www.marcprensky.com/ writing/Prensky\%20-\%20Digital\%20Natives,\%20Digital\%20Immigrants\%20-\%20Part1.pdf (dostęp 10.07.2019).

${ }^{13}$ A. Siewerska-Chmaj, Nowe media, postprawda i populizm, czyli dlaczego millenialsi odwracaja się od demokracji, w: Nauki o mediach i komunikacji społecznej. Krystalizacja dyscypliny w Polsce. Tradycje, nurty, problemy, rezultaty, A. Adamski, S. Gawroński, M. Szewczyk (red.). Warszawa 2017, s. 502-503. 
je, pokolenie młodych muzułmanów w tym przypadku niczym nie różni się od swoich rówieśników na całym świecie.

\section{E-DŻIHAD}

Przyczyn wzrastającej popularności ideologii dżihadu w Internecie można wymienić kilka. Jedną z nich jest niewątpliwe ciągle wzrastająca popularność mediów społecznościowych. Pod koniec 2018 roku na świecie z Facebooka korzystało ponad 2 miliardy użytkowników. Wśród nich najliczniejszą grupę stanowią ludzie w wieku od 18 do 34 lat. Podobnie chętnie młodzi ludzie korzystają z platformy YouTube czy Instagram ${ }^{14}$. Znaczący wzrost popularności Internetu jest również zauważalny w świecie arabskim - kolebce radykalnych ruchów islamistycznych. Według szacunkowych danych z Internetu korzysta obecnie $180 \mathrm{mi}$ lionów Arabów, co stanowi ponad 67\% ogólnej populacji ${ }^{15}$. W 2010 roku było ich zaledwie 56 milionów, co pokazuje, jak gwałtownie rozwija się cyberprzestrzeń w tym regionie świata. Wśród mediów społecznościowych wyraźnie widać dominację Facebooka - w 2017 roku konto na tym portalu posiadało około 156 milionów arabskich użytkowników Internetu, co średnio daje prawie 7 milionów kont na tym medium przypadających na każde z państw arabskich ${ }^{16}$.

Drugą przyczyną, nierozerwalnie związaną z pierwszą, jest brak jednej wykładni zasad religijnych w islamie sunnickim. Pojęcie dżihadu oznacza podejmowanie codziennych wysiłków, które mają zbliżyć człowieka do Boga. Dżihad nie oznacza wprost „świętej wojny”, walka zbrojna dozwolona jest jedynie w obronie własnej wiary. Jednak, jako że nie istnieje jedna obowiązująca wykładnia Koranu, ugrupowania terrorystyczne i radykalne organizacje islamistyczne interpretują dżihad jako obowiązkową walkę zbrojną z niemuzłumanami, a możliwości stworzone przez nowe media sprawiają, że ich interpretacja zdobywa - niedostępne im

${ }^{14}$ M. Kuchta, Ilu użytkowników korzysta z sieci i social media w 2019 roku?, SocialPress, 4.09.2019, https://socialpress.pl/2019/02/ilu-uzytkownikow-korzysta-z-sieci-i-socialmedia-w-2019-roku (dostęp 10.09.2019).

${ }^{15}$ Internet World Status, Usage and Population Statistic, 2019, https://www.internetworldstats.com/stats5.html (dostęp, 10.06.2019).

${ }^{16}$ L. Khalife, For Arabs, Facebook is still the most popular Internet platform, 2017, https:// stepfeed.com/for-arabs-facebook-is-still-the-most-popular-internet-platform-8095 (dostęp 10.07.2019). 
do tej pory - szerokie grono odbiorców. Interpretacja ta zyskuje w pewien sposób swoje uzasadnienie poprzez wydarzenia, które miały miejsce w ostatnich latach na Bliskim Wschodzie. Toczący się wciąż konflikt izraelsko-palestyński, wypowiedziana przez G.W. Busha wojna z terroryzmem czy w końcu Arabska Wiosna ze wszystkimi swoimi konsekwencjami niewątpliwe doprowadziła do radykalizacji nastrojów części społeczeństw muzułmańskich, a przy okazji wydarzenia te stały się głównym tematem stron internetowych, zachęcających nowych rekrutów do przyjęcia ideologii dżihadu.

Niewątpliwe kolejnym czynnikiem wzrostu aktywności ideologii dżihadu w sieci było również wykorzystanie z sukcesem przez arabskich aktywistów nowych mediów podczas Arabskiej Wiosny nie tylko do organizacji protestów, ale również do zmiany myślenia części młodych mieszkańców państw arabskich. Wydarzenia te stały się inspiracją dla ekstremistycznych organizacji islamistycznych, które w nowych mediach zaczęły upatrywać doskonałe narzędzie własnej propagandy ${ }^{17}$.

Ponadto nie bez znaczenia jest również obecna sytuacja na świecie, która niezwykle sprzyja internetowej działalności radykalnych organizacji islamistycznych. Bunt młodego pokolenia muzułmanów mający swoje źródło w trudnej sytuacji społeczno-ekonomicznej, poczuciu wykluczenia oraz braku celowości własnego życia jest charakterystyczny zarówno dla młodych mieszkańców Bliskiego Wschodu, Azji, Afryki, Europy czy Stanów Zjednoczonych. Poszukując własnej tożsamości oraz winnych sytuacji, w której się znaleźni, trafiają do sieci, gdzie w swym naturalnym już środowisku znajdują odpowiedź na większość nurtujących ich pytań, stając się niepostrzeżenie wyznawcami ideologii dżihadu.

\section{COOL/POP/STREET JIHAD}

Z przeprowadzonych badań wynika, że można dokonać swoistego podziału pomiędzy cool a street/pop jihadem. Jihad cool to termin, który opisuje zjawisko swoistego rebrandingu zbrojnego dżihadu w „modny styl życia” przy zastosowaniu mediów społecznościowych. Po raz pierwszy to sformułowanie zostało użyte przez psychiatrę i byłego oficera CIA Marca Sagemana do opisania wpływu

${ }^{17}$ M. El-Ghamari, Cool jihad, Warszawa 2018, s.182-185. 
al-Kaidy na Internet ${ }^{18}$. Cool jihad jest synonimem „modnego życia”, którego oferta skierowana jest do młodych muzułmanów żyjących na Zachodzie i w państwach muzułmańskich, i ma na celu zachęcenie ich do przystąpienia do danej organizacji terrorystycznej. Natomiast pop/street jihad (twórcą tego terminu jest niemiecka badaczka Claudia Dantchke) to zjawisko występujące w państwach Europy

Cool jihad jest synonimem „modnego życia”, którego oferta skierowana jest do młodych muzułmanów żyjących na Zachodzie i w państwach muzułmańskich i ma na celu zachęcenie młodych ludzi do przystąpienia do danej organizacji terrorystycznej. Natomiast pop/street jihad to zjawisko występujące w państwach Europy Zachodniej, w których zamieszkuje liczna mniejszość muzułmańska. Jego celem jest m.in. zniechęcenie młodych muzułmanów do integracji z kulturą europejską i wprowadzenie w życie zasad ultrakonserwatywnej odmiany islamu.

Zachodniej (głównie w Niemczech, Belgii, Holandii i państwach skandynawskich), w których zamieszkuje liczna mniejszość muzułmańska. Jest on mocno powiązany z europejskim salafizmem ${ }^{19}$ (radykalnym odłamem islamu, który głosi m.in. powrót do fundamentów religii i neguje zachodnioeuropejskie wartości), a jego

${ }^{19}$ Salafizm - ruch w odłamie sunnickiego islamu, który miał swoje początki w XVIII wieku na terenie Arabii Saudyjskiej. Ssalafici wzywają do powrotu do korzeni islamu, głosząc jego najbardziej konserwatywną wersję, część z nich stara się ją promować poprzez pokojową prozelityzację. Jednym z odłamów ruchu - najbardziej widocznym w Europie - są dżihadyści, którzy realizują również ultrakonserwatywny program religijny, ale głoszą potrzebę zbrojnego powstania do jego osiągnięcia. (przyp. autorki). 
celem jest m.in. zniechęcenie młodych muzułmanów do integracji z kulturą europejską i wprowadzenie w życie zasad ultrakonserwatywnej odmiany islamu.

\section{Cool jihad}

Termin cool jihad został po raz pierwszy zastosowany do opisania wpływu al-Kaidy $^{20}$ na Internet. Al-Kaida w lipcu 2010 roku zaczęła wydawać magazyn „Inspire", którego anglojęzyczna wersja była dostępna online. Język magazynu (amerykańsko-angielski slang), jak również jego layout jasno wskazywał, że odbiorcami w założeniu redakcji mieli zostać młodzi ludzi, do których skierowano jasny przekaz. Atrakcyjny obraz dżihadu został dostosowany do możliwości odbiorczych współczesnej młodzieży, zarówno język jak i szata graficzna niczym nie odbiegały od języka znanego z MTV czy obrazków z gier komputerowych ${ }^{21}$.

Doświadczenia al-Kaidy szybko zostały spożytkowane przez Państwo Islamskie - organizację terrorystyczną, która najpełniej wykorzystywała i wciąż wykorzystuje możliwości jakie dają jej nowe media ${ }^{22}$. Przyczyną popularności przesłania cool jihadu w wykonaniu ISIS jest dokładne zrozumienie potrzeb docelowych odbiorców komunikatów. Kluczowymi elementami retorycznej perswazji cool jihadu z jednej strony jest łatwo przyswajalny język (najczęściej angielski lub amerykański slang), z drugiej strony umiejętność stworzenia „estetyki MTV”. Przygotowywane filmy wideo tworzone są na podobieństwo gier komputerowych, których szata graficzna stoi na najwyższym poziomie. Do tego świata wprowadzane są także prawdziwe postaci. Analizując konta na portalach społecznościowych, można dostrzec pewien schemat. Radykalni bojownicy pokazani są z kotami czy psami, a także z zachodnimi produktami, które mogą przybliżyć ich

${ }^{20} \mathrm{Al}$-Kaida - ugrupowanie terrorystyczne powstałe w 1988 roku w celu przeciwstawienia się rosyjskiej inwazji na Afganistan, z czasem rozszerzyło swoje cele do walki z wpływami Zachodu na kulturę muzułmańską. Jego największym „osiągnięciem” było przeprowadzenie zamachów w USA 11.09.2001 roku. Obecnie al-Kaida podzielona jest na kilka odłamów. Charakterystyczną cechą Al-Kaidy jest jej luźna, zdecentralizowana struktura, zabezpieczająca przed zniszczeniem organizacji z chwilą rozbicia którejkolwiek jej części (przyp. autorki).

${ }^{21}$ IPT News, Jihad is Cool: Jihadist Magazines Recruit Young Terrorists, 11, April 2013, http://www.investigativeproject.org/3969/jihad-is-cool-jihadist-magazines-recruit-young\# (dostęp 20.07.2019).

22 22Pomimo oficjalnego ogłoszenia końca Państwa Islamskiego organizacja nie przestała istnieć, jej działalność w dużej mierze przeniosła się do sieci, a dzięki ogromnej liczbie materiałów w Internecie wyprodukowanych przez ISIS Państwo Islamskie powoli zyskuje nazwę „Cyfrowego Kalifatu” (przyp. autorki). 
do odbiorców - np. bojownicy jedzą kanapki z Nutellą, piją Red Bulla, są w koszulkach Batmana i twierdzą, że ISIS jest w stanie pokonać Ligię Sprawiedliwości czyli zespół komiksowych superbohaterów. W mediach społecznościowych można dostrzec wiele kont islamskich bojowników, którzy umieszczają własne selfie z różnych wydarzeń. Niektóre z nich zdobywają międzynarodową popularność jak np. konto Holendra tureckiego pochodzenia o pseudonimie Yimlaz, który świadomy swej sławy prowadził własne profile społecznościowe w sposób w jaki robią to gwiazdy Hollywood ${ }^{23}$.

Siłą cool jihadu jest dokładne dopasowanie przekazu do swoich adresatów. Konta bojowników na portalach społecznościowych emanują męskością, siłą, pewnością siebie, a to wartości ważne zarówno w kulturze arabskiej, jak i dla obrazu mężczyzny w islamie. W dobie takich zjawisk jak cyfrowy narcyzm czy diagnozowanej już przez psychologów depresji facebookowej, możliwość kreacji swojego wizerunku, który ucieleśnia wymienione wyżej wartości jest dla młodych muzułmanów niezwykle atrakcyjny. Dla selfie z bronią w ręku lub z pola walki, które zdobędzie ogromną liczbę „polubień” na Facebooku są w stanie porzucić swoje dotychczasowe życie i przyłączyć się do wybranej organizacji terrorystycznej.

Ponadto oba ugrupowania (jak również inne organizacje terrorystyczne np. Hamas czy Hezbollah) chętnie wydają gry komputerowe, które mają za zadanie oswoić odbiorców z przemocą. Najpopularniejszą grą, która powstała pod szyldem ISIS, jest gra zatytułowana „Salil al-Sawarem” czyli „Szczęk mieczy”. Na okładce gry użytkownik może przeczytać: „Ta gra została stworzona specjalnie dla Ciebie, robimy to samo na polu bitwy!". Innymi słowy, rodzaje prawdziwych konfrontacji zbrojnych, w które angażuje się ISIS, są podobne do wirtualnych wojen toczonych w grach wideo. Co więcej, sama nazwa nadana grze ma przywodzić na myśl ideę siły, nieustraszoności i odporności w czasie wojny. Zasadniczo grupą docelową takich gier wideo są młodzi ludzie, którzy w sposób naturalny powinni być bardziej zainteresowani brutalnymi „strzelankami”, dzięki którym mogą poczuć się zdobywcami szybko zyskującymi sławę i nagrodę za poniesione wysiłki ${ }^{24}$.

${ }^{23}$ C. J. S. Picart, "Jihad Cool/Jihad Chic": The Roles of the Internet and Imagined Relations in the Self-Radicalization of Colleen LaRose (Jihad Jane), "Societies", 2015, 5(2), doi:10.3390/ soc5020354.

${ }^{24}$ A. Al-Rawi A., Video games, terrorism, and ISIS's Jihad 3.0, "Terrorism and Political Violence Journal”, https://www.tandfonline.com/doi/citedby/10.1080/09546553.2016.1207633? 
Ugrupowania terrorystyczne nie zapominają również o produkcji gadżetów, dzięki którym młodzież może utożsamiać się z ich wartościami. W Internecie można kupić bluzy, koszulki czy inne gadżety jawnie „reklamujące” daną organizację terrorystyczną ${ }^{25}$. Dżihad staje się modą, za którą stoi zabijanie niewiernych. Wydaje się jednak, że młodzi ludzie nie zawsze zdają sobie z tego sprawę.

\section{Pop/street jihad}

Jedną z najbardziej konserwatywnych wersji islamu obecną w Europie Zachodniej jest ta głoszona przez salafitów. Salafici nawołują do odrodzenia islamu poprzez „powrót do jego źródeł”, co w praktyce oznacza dążenie do wprowadzenia islamskiego państwa wyznaniowego, rządzonego w oparciu o szariat, czyli islamskie prawo religijne, regulujące także życie codzienne muzułmanów zamieszkałych na stałe w państwach zachodnich. Stawia to ruch salafitów na pozycji zaciekłego wroga demokracji zachodnich i zachodniego stylu życia.

Od około 2011 roku w zachodniej Europie rozwija się radykalna salaficka subkultura młodzieżowa, której główną cechą jest działanie oddolne bez mentorów i szejków, którzy staliby na czele ruchu. Jej przesłanie jest radykalne, ale sposób w jaki jest przekazywane, jest zgodny z zasadami popkultury. Za pośrednictwem mediów społecznościowych udostępnia się krótkie klipy wideo z modną muzyką rap, w odpowiedniej estetyce z gier komputerowych lub apokaliptyczne filmy skierowane wprost do młodzieży. Siłą pop jihadu jest jego oferta skierowana do młodych ludzi. Pop jihad proponuje celebrycką przygodę w miejsce nudnego, bezproduktywnego życia. Ponadto w swoim przesłaniu jasno piętnuje odpowiedzialnych za doznane rozczarowania i poczucie wykluczenia, często wskazując na szkołę, rodzinę czy sytuację społeczno-polityczną ${ }^{26}$. Ta cecha pop jihadu okazała się szczególnie interesująca dla młodych muzułmanów lub konwertytów na islam, którzy wcześniej mieli problemy z prawem. Według prof. Sandberga 68\% procent radykalnych dżihadystów w Norwegii miało wcześniej zatargi z prawem. To połączenie pomiędzy przestępstwem a religią nie jest przypadkowe. Młodzi ludzie, którzy często szukają możliwości zmiany dotychczasowego życia, traktu-

scroll=top\&needAccess=true (dostęp 12.07.2019), https://doi.org/10.1080/09546553.2016 .1207633

${ }^{25}$ M. Ghamari, dz.cyt., s. 214.

${ }^{26}$ Why do young people join the jihad?, 2017, Deutschland.de, 20.07.2017, https://www. deutschland.de/en/topic/politics/why-do-young-people-join-the-jihad (dostęp 3.07.2019). 
ją dżihad jako drogę do odkupienia win. W ten sposób dochodzi do połączenia pomiędzy uliczną kulturą przestępców a ekstremistycznymi ugrupowaniami islamistycznymi. W tym wypadku street jihad staje się swoistą mieszanką ulicznego rapu, slangu i odzieży z radykalną wersją islamu ${ }^{27}$.

Na szczególną uwagę w tym przypadku zasługuje Francja - kraj, który ma największy odsetek mniejszości muzułmańskiej w Europie. Francuskie więzienia stały się miejscami radykalizacji i krystalizacji poglądów młodych muzułmanów z przedmiejskich blokowisk, którzy w więzieniach szybko przechodzili pod opiekę samozwańczych imamów - najczęściej związanych z salafizmem. Do tej pory wykluczeni, nagle stali się częścią elity. Jak piszą w swojej książce Gelles Kepel i Antonie Jardine: „Wyobrażają sobie, że ich religia to walka [...] dla narzucenia własnej władzy. W ten oto sposób przemoc staje się najważniejszą drogę dla kogoś, kto chce być dobrym muzułmaninem"28. Po wyjściu z więzienia ten pogląd staje się spopularyzowany dzięki nowym mediom, a Francja, nie bez przyczyny najmocniej z państw europejskich, w których zamieszkuje mniejszość muzułmańska, zmaga się ze zjawiskiem trzeciej fazy dżihadu.

Dzięki zaangażowaniu w pop jihad młodzi ludzie mają poczucie przynależności do muzułmańskiej elity, która - w przeciwieństwie do innych - nie toleruje upokorzenia i degradacji, ale zamiast tego walczy i broni sprawiedliwości. Jednak traktowanie pop jihadu jako modnej subkultury doprowadza do paradoksalnej sytuacji, w której młodzi adepci dżihadu mają dużo większą wiedzę na temat gwiazd ulicznego rapu niż chociażby postaci Osamy bin Ladena. Ich przynależność do ruchu polega głównie na słuchaniu jihad rapu, odpowiednim stroju oraz wrzucaniu do sieci selfie nawiązujących do kultury bliskowschodniej podpisanych islamistycznymi hashtagami. W ich umysłach dżihad jawi się jako kolejna misja Jamesa Bonda, podczas której doświadczą niezwykłych przygód, które nie były im do tej pory dostępne. Zbrojne szkolenia traktują jak ćwiczenia Rambo, a możliwość

${ }^{27}$ T. Brunton-Douglas T. 2018, How Gangsters Become Jihadists (And Why Most Don't): Bourdieu, Criminology, and the Crime-Terror Nexus, Sveinung Sandberg, University of Oslo, 5.11.2018, https://www.law.ox.ac.uk/centres-institutes/centre-criminology/blog/2018/11/ how-gangsters-become-jihadists-and-why-most-dont (dostęp 15.06.2019).

${ }^{28}$ G. Kepel, A, Jardin, Terror we Francji. Geneza francuskiego dżihadu, Warszawa 2017, s. 77. 
zabijania ludzi, jako doświadczenie gry komputerowej na żywo. W ich pojęciu dżihadu pobudki religijne wydają się nie mieć większego znaczenia ${ }^{29}$.

Pop jihad bardzo łatwo dostosował się do kultury mediów młodzieżowych. Korzystając z możliwości jakie dają nowe media „pop-dżihadyści” zdołali stać się częścią ogólnej muzułmańskiej kultury młodzieżowej, uzyskując w ten sposób bezpośredni dostęp do swojej głównej grupy docelowej. Znaczącą rolę w pop jihadzie odgrywają tzw. nasheedy czyli tradycyjne islamskie hymny, które w wersji pop/street jihadu zyskują połączenia z rapem i hip-hopem oraz nową warstwę tekstową. Dzięki tej muzyce ruch wyraża swój bunt i gniew, a także poczucie beznadziei i wykluczenia. Sprowadzona do prostych wiadomości poprzez formę nasheedów ideologia dżihadu staje się atrakcyjna dla nastolatków, którzy nie są już ani pobożnymi muzułmanami ani gorliwymi salafitami, ale mają własną koncepcję dżihadu stworzoną wcześniej poprzez konsumpcję nowych mediów. Młodzież ta nie jest już zainteresowana długimi kazaniami w meczecie ani uczestnictwem w seminariach na temat salafizmu. Jako „cyfrowi tubylcy” nie są w stanie przyswoić tej formy przekazu. Pop/street jihad stał się stylem życia, który wygląda i brzmi atrakcyjnie i dla którego nie trzeba opuszczać Internetu ${ }^{30}$.

\section{ZAKOŃCZENIE}

Cool/pop/street jihad to zjawiska oddające nastroje młodych muzułmanów, to sposób na wyrażenie własnej frustracji przeciwko wykluczeniu, biedzie, otaczającej beznadziei. Jako przedstawiciele pokolenia „cyfrowych tubylców” młodzi muzułmanie szukają odpowiedzi na pytanie o własną tożsamość w sieci, gdzie często poprzez algorytmy stosowane przez media społecznościowe stają się ofiarami dżihadystycznej bańki informacyjnej. Szukając wiedzy na temat islamu, który dla drugiego i trzeciego pokolenia muzułmanów w Europie często stał się wyznacznikiem tożsamości wobec kulturowego zawieszenia pomiędzy krajem swoich rodziców a krajem, w którym się urodzili, trafiają na coraz więcej informacji, które mogą przekonywać ich, że dżihad jest cool.

\footnotetext{
${ }^{29}$ J. Jivani, Why Young Men: The Dangerous Allure of Violent Movements and What We Can Do..., New York 2019, s. 135-143.

${ }^{30}$ C. Dantschke, "Pop-Jihad" History and Structure of Salafism and Jihadism in Germany, Institute for the Study of Radical Movements, Working Paper Series 02/13, 2013.
} 
Największym niebezpieczeństwem tych ideologii jest promocja zbrojnego dżihadu jako modnego stylu życia, który chce być naśladowany przez coraz większą liczbę młodych muzułmanów. Trywializacja zła i przemocy doprowadza do sytuacji, w której uczestnictwo w zbrojnym dżihadzie traktowane jest jak udział w atrakcyjnej grze komputerowej, której efektami, dzięki możliwościom jaką dają nowe media, można „pochwalić się” przed całym światem. Ponadto jeśli potraktujemy zjawiska cool/pop/street jihadu jako nowe ruchy społeczne, to okaże się, że nowe media również $\mathrm{w}$ tym przypadku doprowadziły do trywializacji wsparcia elit rozumianych tutaj jako liderów religijnych w postaci imamów, szejków czy mentorów religijnych. Ruchy te tworzone są oddolnie przez młodych i dla młodych, dlatego ich przesłanie jest tak doskonale zrozumiałe przez odbiorców, a jednocześnie tak niebezpieczne. Młodzież nie znosi stagnacji, więc z czasem napisy na koszulkach czy naszywkach na ubraniach, słowa ulubionej piosenki albo scenariusz gry komputerowej bez namysłu może wprowadzić w czyn.

\section{BIBLIOGRAFIA}

Al-Rawi A., Video games, terrorism, and ISIS's Jihad 3.0, "Terrorism and Political Violence Journal", 2016 https://www.tandfonline.com/doi/citedby/10.1080/09546553.2016. 1207633?scroll=top\&needAccess=true (12.07.2019), https://doi.org/10.1080/095 46553.2016.1207633

Arab Development Portal, Demography, 2018, http://www.arabdevelopmentportal.com/ indicator/demography (1.06.2019).

Bolechów B., Baza w sieci. Wykorzystanie Internetu przez Al-Kaide i jej zwolenników, w: Terroryzm w medialnym obrazie świata, r. K. Liedel, S. Mocek (red.) Warszawa 2010.

Brunton-Douglas T., How Gangsters Become Jihadists (And Why Most Don't): Bourdieu, Criminology, and the Crime-Terror Nexus, Sveinung Sandberg, University of Oslo, 5.11.2018, https://www.law.ox.ac.uk/centres-institutes/centre-criminology/blog/2018/ 11/how-gangsters-become-jihadists-and-why-most-dont, (15.06.2019).

Dantschke C., "Pop-Jihad" History and Structure of Salafism and Jihadism in Germany, Institute for the Study of Radical Movements, Working Paper Series 02/13, 2013.

Dhillon, D., Dyer P., Yousef T., Generation in Waiting. The Unfulfilled Promise of Young People in the Middle East, Washington 2009.

El-Ghamari M., Cool Jihad, Warszawa 2018.

Górak-Sosnowska K., Muzułmanie w Europie. Dystans kulturowy, szanse asymilacji i integracji, w: Współczesna Europa w procesie zmian. Wybrane problemy, J. Polakowska-Kujawa (red.), Warszawa 2006, s. 236-253. 
Hackett C., 5 facts about the Muslim population in Europe, Pew Research Center, https:// www.pewresearch.org/fact-tank/2017/11/29/5-facts-about-the-muslimpopulation-in-europe/, 2018, (10.07.2019).

Internet World Status, Usage and Population Statistic 2019, https://www.internetworldstats.com/stats5.htm (10.06.2019).

IPT News, Jihad is Cool: Jihadist Magazines Recruit Young Terrorists, 11.04.2013, http:// www.investigativeproject.org/3969/jihad-is-cool-jihadist-magazines-recruit-young\# (20.07.2019).

Jivani J., Why Young Men: The Dangerous Allure of Violent Movements and What We Can Do..., New York 2019.

Kepel G., Jardin A., Terror we Francji. Geneza francuskiego dżihadu, Warszawa 2017.

Khalife L., For Arabs, Facebook is still the most popular Internet platform, 2017, https:// stepfeed.com/for-arabs-facebook-is-still-the-most-popular-internet-platform-8095, (10.07.2019).

Kuchta M., Ilu użytkowników korzysta z sieci i social media w 2019 roku?, SocialPress, 4.09.2019, https://socialpress.pl/2019/02/ilu-uzytkownikow-korzysta-z-sieci-isocial-media-w-2019-roku (10.09.2019).

Nacos B.L., Mass Mediated Terrorism, Oxford 2002.

Nomani, A. Q., Jihad Wannabes, “New York Magazine",22.03.2010, http://nymag.com/ news/intelligencer/64955/ (17.07.2019).

Picart C. J. S., "Jihad Cool/Jihad Chic": The Roles of the Internet and Imagined Relations in the Self-Radicalization of Colleen LaRose (Jihad Jane), "Societies", 2015, 5(2), doi: $10.3390 /$ soc5020354.

Prensky M., Digital Natives, Digital Immigrants, 2001, https://www.marcprensky.com/ writing/Prensky\%20-\%20Digital\%20Natives,\%20Digital\%20Immigrants\%20 -\%20Part1.pdf (10.07.2019).

Sawicka, Z., Islam w Europie czy europejski islam. Kwestia wartości, w: W pułapce wielokulturowości, w: W pułapce wielokulturowości, Siewierska-Chmaj A. (red.), Warszawa 2016, s. 53-70.

Seib P., Janek D. M., Global Terrorism and New Media: The Post-Al Qaeda Generation, New York 2011.

Siewierska-Chmaj A., Nowe media, postprawda i populizm, czyli dlaczego millenialni odwracaja się od demokracji, w: Nauki o mediach i komunikacji społecznej, krystalizacja dyscypliny w Polsce. Tradycje, nurty, problemy, rezultaty, Adamski A., Gawroński S., Szewczyk M. (red.), Warszawa 2017, s. 497-510.

Weimann, G., Terror on the Internet: The New Arena, the New Challenges, Washington 2006.

Weimann, G., New Terrorism and New Media, Wilson Center, 2014 https://www.wilsoncenter.org/sites/default/files/STIP_140501_new_terrorism_F.pdf (10.07.2019).

Weiss M., Hassan, H., ISIS wewnq̨trz armii terroru, Warszawa 2015. 
Why do young people join the jihad?, 2017, Deutschland.de, 20.07.2017, https:// www.deutschland.de/en/topic/politics/why-do-young-people-join-the-jihad (3.07.2019).

Zdanowski J., Muzułmanie $w$ świecie zachodnim. Stare i nowe tożsamości, „Krakowskie Studia Międzynarodowe", numer IV, 2007.

\section{Biogram}

Zofia Sawicka - doktor nauk społecznych z zakresu nauki o mediach, adiunkt w Kolegium Mediów i Komunikacji Społecznej w Wyższej Szkole Informatyki i Zarządzania w Rzeszowie, pracownik Instytut Badań nad Cywilizacjami. Swoje zainteresowania naukowe koncentruje wokół szeroko pojętej problematyki krajów arabskich oraz islamu, ze szczególnym uwzględnieniem roli nowych mediów w przemianach politycznych na Bliskim Wschodzie. Autorka publikacji dotyczących roli mediów w świecie arabskim, sytuacji politycznej na Bliskim Wschodzie, islamu oraz Arabskiej Wiosny, w tym m.in. książki Wpływ nowych mediów na przemiany polityczne wybranych państw Bliskiego Wschodu na przykładzie Arabskiej Wiosny.

e-mail: zawicka@wsiz.rzeszow.pl, https://orcid.org/0000-0001-7679-5303 


\title{
Marta Jarosz
}

\author{
Instytut Edukacji Medialnej i Dziennikarstwa UKSW w Warszawie
}

\section{Możliwości kontra oczekiwania. Jak komunikują się instamatki i jakie wartości wyznają?}

\section{Opportunities versus expectations. How do instamatki communicate and what values are important to them?}

\begin{abstract}
ABSTRAKT
Coraz więcej młodych kobiet, które spodziewają się dziecka lub już zostały matkami, zakłada konta na Instagramie

i traktuje je jako pamiętnik z nowego rozdziału życia. Instamatki - bo tak same siebie nazywają kobiety dokumentujące zdjęciami różne oblicza macierzyństwa - to już zorganizowana grupa, której członkinie często znają się także w realnym świecie. To, co można zobaczyć na pokazywanych przez nie fotografiach - w połączeniu z charakterystycznymi opisami zdjęć i komentarzami pod nimi - skłania do licznych refleksji. Nasuwają się pytania

m.in. o to, jakie potrzeby kobiet zaspokaja komunikowanie o macierzyństwie w mediach społecznościowych, jakich środków wyrazu używają w zamieszczanych w Sieci wpisach i co decyduje o ich wyborze, jaki obraz macierzyństwa wyłania się z analizy publikowanych przez nie treści, i wreszcie: jakie wartości są dla nich ważne. Próba odpowiedzi na nie zostaje podjęta w poniższym artykule.
\end{abstract}

SŁOWA KLUCZOWE:

Instagram; instamatki; komunikacja językowa w Internecie; język wartości

\begin{abstract}
More and more young women who are expecting a child or have already become mothers are setting up Instagram accounts and treating them as a diary from a new chapter of life. Instamatki because that is how women documenting various faces of motherhood call themselves - are already an organized group whose members often know each other in the real world. The photographs they show - in conjunction with the characteristic descriptions and comments below them - provoke numerous reflections. Questions arise, among others: what women's needs are met by communicating about motherhood in social media, what means of expression they use in entries posted on the Web and what determines their choice, what picture of motherhood emerges from the analysis of the content they publish, and finally: what values are important to them.
\end{abstract}

\section{KEYWORDS:}

Instagram; instamatki; language communication on the internet; language of values 


\section{INSTAMATKI JAKO SPOŁECZNOŚĆ WIRTUALNA}

Współcześni badacze różnie definiują pojęcie społeczności wirtualnej. Howard Rheingold ${ }^{1}$, pisząc o ich istocie, akcentuje np. uczucia rodzące się $\mathrm{w}$ trakcie długotrwałych dyskusji i pozwalające na stworzenie osobistych relacji miedzy jednostkami. Wadhwa i Kotha ${ }^{2} \mathrm{z}$ kolei wskazują na zamierzony charakter uczestnictwa we wspólnocie wirtualnej. Ich zdaniem możliwość podjęcia decyzji o przystąpieniu do niej to ważny element budujący wspólnotę. 0 ile bowiem w realnej rzeczywistości jednostki często stają się członkami różnych społeczności niejako mimowolnie, o tyle w przypadku dołączania do grupy istniejącej w Sieci, mogą swobodnie wybierać i decydować o członkostwie w nich. W kontekście problematyki instamatek godna wskazania wydaje się także definicja Slouvki³ ${ }^{3}$ który proponuje nazywanie społecznościami wirtualnymi zbiorów osób, które łączą wspólne pasje i praktyki. Na uwagę zasługują także spostrzeżenia Leigha Claytona ${ }^{4}$, który w swoim próbach systematyzacji czynników decydujących o powstawaniu wspólnot wirtualnych wymieniał m.in. wolność i możliwość pokonania barier geograficznych oraz innych dzielących jednostki i utrudniających im kontakt face to face.

Mając na uwadze powyższe ustalenia, można stwierdzić, że instamatki spełniają większość warunków pozwalających na nazwanie ich społecznością wirtualną. W październiku 2019 roku ponad 1,5 miliona zdjęć zamieszczonych na Instagramie było opatrzonych tym hasztagiem. 0 tym, jak szybko ich liczba rośnie, można się przekonać, porównując wynik z kwietnia 2016 roku. Wtedy hasztag \#instamatki był przyporządkowany do nieco ponad 132 tysięcy fotografii ogólnie dostępnych na Instagramie. Warto przy tym zwrócić uwagę, że równocześnie ze wspomnianym hasztagiem współistnieje inna jego wersja, w liczbie pojedynczej \#instamatka. W październiku 2019 roku był on przypisany do nieco ponad 430 tysięcy zdjęć. Prawie 6,6 miliona zdjęć było natomiast opisanych hasztagiem \#instamama. Wszystkie trzy oznaczenia bardzo często pojawiają się przy tym samym

${ }^{1}$ H. Rheingold, The Virtual Community: Homestanding on the Electronic Frontier. Reading, MA: Addison-Wesley, 1993.

${ }^{2}$ A. Wadhwa, S. Kotha, Research Associate Anu Wadhwa, University of Washington, 1999. http://us.badm.washington.edu/kotha/internet/handouts/vc5.PDF (dostęp: 14.06.2019 r.)

${ }^{3}$ M. Slouvka, War of the Worlds: the assault on reality, London: Abacus, 1996.

${ }^{4}$ L. Clayton, Are there Virtual Communities? http://www.abdn.ac.uk/philosophy/endsandmeans/vol2no1/clayton.shtml (dostęp: 14.06.2019 r.). 
zdjęciu - wraz z innymi hasztagami. Stanowi to ważną informację dla odbiorców postów, bo obrazy pokazane na wielu z tych fotografii nie pozwalałyby zidentyfikować widocznych na nich postaci czy chwil z ich życia jako „dokumentacji życia matki”. Hasztagi są niejako znakiem rozpoznawczym społeczności, a ich użycie to sposób na przyłączenie się do niej i nawiązanie interakcji z innymi jej członkami. Co ciekawe, anglojęzyczne hasztagi, który można by uznać za odpowiedniki polskojęzycznych, nie są aż tak popularne - \#instamother liczy aktualnie 187279 wystąpień, a \#instamom - 4,8 miliona.

Biorąc pod uwagę sposób przystępowania do społeczności instamatek, można zauważyć jego łatwość i niejako samozwańczy charakter. To użytkowniczka Instagramu decyduje o tym, czy oznacza w określony sposób swoje fotografie, czy w opisie swojego konta definiuje się jako \#instamatka (lub matka w ogóle, bo to też w pewien sposób pozwala identyfikować się ze społecznością) i wreszcie, czy będzie aktywną uczestniczką tej nieformalnej, a jednak wyraźnie zżytej i połączonej więzią zrzeszeniową 5 grupy. Jej działanie w tym kierunku nie musi zyskać akceptacji kogokolwiek już zaangażowanego w funkcjonowanie społeczności. Grupa jest jednak wewnętrznie zróżnicowana i dołączając do niej, nie można liczyć na automatyczne zyskanie popularności.

Najogólniej rzecz ujmując, wśród instamatek można wyróżnić 3 podstawowe podgrupy wchodzące w skład społeczności:

- matki celebrytki - dla nich macierzyństwo i relacjonowanie go w Sieci to pewnego rodzaju dodatek do działalności w show-biznesie; do tej grupy można zaliczyć przede wszystkim aktorki, partnerki i żony znanych sportowców, aktorów, modeli, postaci znane z udziału w popularnych programach telewizyjnych;

- tzw. królowe Sieci - kobiety należące do tej grupy, zanim stały się instamatkami, były aktywne na innych płaszczyznach Internetu; w szczególności prowadziły poczytne blogi o różnorodnej tematyce - zarówno parentingowej, jak i podróżniczej, a także wnętrzarskiej i szeroko pojętej lifestyle'owej;

${ }^{5}$ M. Szpunar, Społeczności wirtualne jako społeczności - próba ujęcia socjologicznego, [w:] „Jednostka-grupa-cybersieć. Psychologiczne, społeczno-kulturowe i edukacyjne aspekty społeczeństwa informacyjnego", red. M. Radochoński, B. Przywara, Rzeszów, WSIiZ, 2004, s. 157-184. 
- postaci anonimowe - kobiet należących do tej grupy nie można powiązać z innym rodzajem aktywności w Sieci, którego celem byłoby budowanie wspólnoty z internautami czy pozyskiwanie korzyści finansowych z prowadzonej działalności.

W kontekście podjętych rozważań warty zauważenia wydaje się moment, w którym kobiety decydują się na dołączenie do społeczności instamatek. W tym obszarze zauważalne są dwie główne tendencje:

- moment zajścia w pierwszą ciążę - zarówno dla internautek, które miały już konto na Instagramie, jak i tych które wcześniej nie miały styczności z opisywanym medium społecznościowym;

- pojawienie się pierwszego dziecka na świecie.

Łatwo zauważyć, że kobiety, które stają się instamatkami krótko po zajściu w ciążę, dokumentują w Sieci nie tylko chwile spędzone już z dzieckiem, ale także czas oczekiwania na nie, przygotowania do narodzin i przebieg ciąży. Śledząc posty zarówno jednych, jak i drugich, można stwierdzić, że ta sieciowa łączność pozwala instamatkom na realizację wszystkich potrzeb, o których piszą w kontekście społeczności wirtualnych Wadhwa i Kotha ${ }^{6}$, a więc:

- komunikacji

- informacji

- rozrywki

- transakcji.

Ze względu na czas, w którym kobiety zwykle dołączają do społeczności instamatek, charakterystyczne dla tej grupy jest to, że jej członkinie najstaranniej dokumentują pierwsze lata życia z dzieckiem. Efekt nowości samego zjawiska istnienia tej społeczności powoduje też, że obecnie najstarsze dzieci najdłużej aktywnych instamatek mają co najwyżej 10 lat, ale ta grupa jest w mniejszości. Najwięcej postów opatrzonych omawianym hasztagiem publikują kobiety, których synowie i córki mają od 0 do 6 lat. W chwili gdy dziecko rozpoczyna edukację najpierw przedszkolną, a później szkolną - i spędza mniej czasu z matką, instagramowiczki modyfikują swoją aktywność w Sieci i zmniejszają liczbę publikacji, którym towarzyszy hasztag utożsamiający je z omawianą społecznością.

${ }^{6}$ A. Wadhwa, S. Kotha, Research Associate Anu Wadhwa, University of Washington, 1999. http://us.badm.washington.edu/kotha/internet/handouts/vc5.PDF. 
Warto także zauważyć, że im wcześniej po urodzeniu dziecka kobiety wracają do pełnej aktywności zawodowej, tym bardziej słabnie ich działalność jako instamatek. Nie można powiedzieć, że całkowicie zanika, ale zdecydowanie zmienia się. Zdjęcia dziecka i z dzieckiem pojawiają się rzadziej, a zastępują je obrazy pokazujące matkę podejmującą inne zajęcia, spędzającą więcej czasu poza domem, kobietę, która godzi wiele obowiązków - w tym również macierzyństwo. Ten model działania daje się zaobserwować głównie u kobiet, dla których aktywność w Sieci, w tym również na Instagramie, nie jest źródłem utrzymania. Zawodowe blogerki, które wraz z pojawieniem się dziecka stały się instamatkami, nie ograniczają liczby publikacji opatrzonych hasztagami identyfikującymi je z wirtualną społecznością kobiet będących w podobnej sytuacji życiowej. Jednak również na ich kontach postać samego dziecka pojawia się na fotografiach rzadziej niż wcześniej.

\section{(...) im wcześniej po urodzeniu dziecka kobiety wracają do pełnej aktywności zawodowej, tym bardziej słabnie ich działalność jako instamatek.}

Niektóre instamatki z najdłuższym stażem aktywności, których dzieci przechodzą do kolejnych etapów życia i nie wymagają już całodobowej uwagi, używają do opisu zdjęć „wspólnotowego" hasztagu wręcz okazjonalnie. Dzieje się to np. na zakończenie czy rozpoczęcie roku szkolnego, w Dniu Matki i Dniu Dziecka, w chwilach obchodzenia rodzinnych jubileuszy czy wtedy, gdy dzieci nabywają nowe umiejętności lub świętują sukcesy.

\section{CHARAKTERYSTYKA KOMUNIKACJI INSTAMATEK}

Elementem identyfikującym członkinie społeczności instamatek są opisane wyżej hasztagi. Stosowanie najpopularniejszych słów do opisu zdjęcia, zwiększa szanse na wyszukanie przez innych użytkowników ${ }^{7}$.

${ }^{7}$ P. Buczek, Instagram jako miejsce komunikacji wizualnej mediów z odbiorcami, „Naukowy Przegląd Dziennikarski" 2017, nr 4, s. 131-141. 
Idąc tropem hasztagów i analizując działania używających ich w Sieci kobiet, można uznać, że instamatki to wspólnota komunikatywna, czyli grupa społeczna, której członkowie odczuwają potrzebę wymiany informacji i potrzebę tę realizują ${ }^{8}$. Kanał, za pomocą którego te działania się dokonują, ma istotny wpływ na charakterystykę komunikacji.

Biorąc pod uwagę to, że podstawowymi założeniami Instagramu było wykonywanie zdjęć, edytowanie ich poprzez nakładanie dostępnych filtrów, gromadzenie i udostępnianie małych dzieł na Facebooku i Twitterze oraz inspirowanie innych użytkowników i komunikowanie się z nimi ${ }^{9}$, można by oczekiwać, że w publikacjach instamatek najważniejszą rolę będą odgrywały fotografie. Faktycznie, to one stanowią podstawę dokonującej się $\mathrm{w}$ tej przestrzeni komunikacji. Nie można jednak przypatrywać się im bez uwzględnienia towarzyszących opisów - zarówno hasztagów, jak i dłuższych wypowiedzi, często mających charakter pamiętnikowych zapisków ${ }^{10}$. Słowa towarzyszące fotografiom nie tylko doprecyzowują przekaz i pełnią funkcję informacyjną. Można wręcz skłaniać się ku stwierdzeniu, że to one decydują o interakcjach odbiorców, zachęcają ich do podejmowania dyskusji w komentarzach i dzielenia się opiniami na sugerowane tematy. 0 tym, że tak się właśnie dzieje, może przekonywać fakt, że wiele opisów zdjęć kończy się bezpośrednim zwrotem do obserwatorów - jasno sformułowanym pytaniem lub prośbą o wypowiedzenie się na wskazany temat - co daje początek dyskusji dokonującej się w komentarzach.

Jan Grzenia w książce pt. Komunikacja językowa w Internecie wskazuje na istnienie w Sieci 3 typów komunikacji międzyludzkiej:

- konwersacyjnego

- korespondencyjnego

- hipertekstowego ${ }^{11}$.

${ }^{8}$ S. Grabias, Język w zachowaniach społecznych, Wydawnictwo Uniwersytetu Marii Curie-Skłodowskiej, Lublin 2003, s. 113.

${ }^{9}$ M. Sadowski, Rewolucja social media, Gliwice 2013, s. 102.

${ }^{10}$ Chcąc potraktować opisywany temat, należałoby też przyjrzeć się zawartości materiałów wideo udostępnianych przez instamatki w postaci tzw. instastories, czyli krótkich filmów zamieszczanych na profilu i dostępnych dla obserwatorów przez 24 godziny od momentu dodania. Ze względu na ich nietrwałość i trudności z dostępem do nich, nie były one jednak włączane do materiału badawczego i poddawane analizie w niniejszym opracowaniu.

${ }^{11} \mathrm{~J}$. Grzenia, Komunikacja językowa w Internecie, Wydawnictwo naukowe PWN, Warszawa 2006, s. 43. 
Przyglądając się postom instamatek, ich opisom oraz dyskusjom, które prowadzone są w zamieszczanych pod nimi komentarzach, można stwierdzić, że dokonująca się tu komunikacja nosi znamiona wszystkich trzech wymienionych typów. Członkinie wspólnoty bez wątpienia prowadzą między sobą dialogi. 0 wyraźnej interakcji świadczy m.in. to, że pisząc komentarze pod zdjęciami, internautki zwracają się do siebie niejako bezpośrednio. Chcąc odpowiedzieć na zadane przez autorkę postu pytanie lub wyrazić sprzeciw wobec opinii wygłoszonej przez inną użytkowniczkę, uczestniczki wirtualnej rozmowy używają jej nicku. Powoduje to, że otrzymuje ona na urządzeniu elektronicznym, którego używa do obsługiwania konta na Instagramie, komunikat o informacji skierowanej konkretnie do niej. Pozostałe rozmówczynie widzą zaś przebieg dyskusji między wszystkimi osobami biorącymi w niej udział.

Specyficzne dialogi z obserwatorami instamatki prowadzą też dzięki jednej z nowszych funkcjonalności Instagramu, tzw. Q\&A - questions and answers. Opcja ta umożliwia wysyłanie pytań do konkretnej osoby. Ich zapis pojawia się w postaci instastories. Osoba, do której skierowane są zapytania, odpowiada na nie również w formie pisanej, a całość „wywiadu” ogląda się w kolejnych krótkich materiałach filmowych.

Najpopularniejsze instamatki okazjonalnie komunikują się z obserwatorami za pomocą jeszcze jednego narzędzia dostępnego na Instagramie - relacji na żywo, tzw. live. 0 tym, że takie wirtualne spotkanie z chętnymi członkami społeczności będzie miało miejsce, kobiety informują z kilkudniowym lub kilkunastogodzinnym wyprzedzeniem. Komunikat jest przekazywany w publikowanym w poście lub krótkim materiale wideo. Z racji tego, że live daje możliwość zadawania na żywo pytań przez uczestników „spotkania” (autor relacji widzi je w formie zapisanej, na ekranie urządzenie, którego używa), instagramowiczki zachęcają obserwatorki do przemyślenia i przygotowania tematów, które chciałyby poruszyć w rozmowie, a czasami same określają zagadnienia, na których będą się koncentrowały w przekazie. Live’y są poświęcane np. prezentacji efektów remontu mieszkania i przebiegowi związanych z tym prac; pokazaniu przedmiotów, których \#instamatka planuje się pozbyć (tzw. wyprzedaż szafy), omówieniu problemu wychowawczego, z którym \#instamatce udało się sobie poradzić i zależy jej na podzieleniu się swoją wiedzą i doświadczeniami z koleżankami.

0 tym, że komunikacja instamatek ma również pewne znamiona komunikacji korespondencyjnej, przekonuje z kolei możliwość wysyłania na Instagramie 
wiadomości prywatnych. Nie są one ogólnodostępne i z ich treścią mogą zapoznać się wyłącznie adresatki. Aktywne instagramowiczki informują jednak na swoich profilach o tym, że takie wiadomości otrzymują, a czasami upubliczniają też niektóre z nich - np. takie, które ich zdaniem są wyrazem hejtu i ich nadawcy powinni zostać w ten sposób ukarani za tego rodzaju przekazy.

\section{Najpopularniejsze instamatki okazjonalnie komunikują się z obserwatorami za pomocą jeszcze jednego narzędzia dostępnego na Instagramie - relacji na żywo, tzw. live.}

Jeśli chodzi o hipertekstowość komunikacji instamatek, to dowodzi jej choćby korzystanie z funkcji „oznaczania” innych użytkowników mediów na zdjęciach. W ten sposób przekazywana jest np. informacja o markach prezentowanych na fotografii produktów czy przyjaciołach autorki, o których wspomina ona w poście. Oznaczanie zdjęć, o którym mowa, to zdecydowanie najpopularniejszy wśród instamatek sposób na prowadzanie działań promocyjnych. Dotyczy to zarówno reklam, za które - jak można się domyślać - pobierają one wynagrodzenie, jak i tych, które odbywają się w ramach szeroko rozumianej współpracy barterowej między członkiniami omawianej społeczności ${ }^{12}$.

\section{RZECZ O ŚWIECIE \#INSTAMATEK}

Tym, co w pierwszej kolejności zwraca uwagę przy próbie analizy jakościowej zawartości postów publikowanych przez instamatki, jest dokonywana przez nie selekcja upublicznianych treści. Na udostępnianych zdjęciach dominują obrazy dokumentujące niemal wyłącznie pozytywne chwile z życia z dzieckiem. Przyglądając się im, można by stwierdzić, że dzieci instamatek nie miewają tzw. gorszych dni, są zawsze uśmiechnięte, spokojne, chętne do zabawy. Rzadko też chorują, a jeśli już to się zdarzy i matka zdecyduje się poinformować członkinie swojej wspólnoty komunikacyjnej o tym problemie, robi to w możliwie najbardziej pozytywny sposób. Kadr zdjęcia wypełnia np. fragment postaci niemowlęcia, które po trudnych doznaniach związanych z chorobą zasnęło wyczerpane. Scenerią 
dla tego obrazu jest perfekcyjnie urządzony pokój. Dziecko nie nosi żadnych fizycznych znamion choroby. Wygląda tak jak każdy jego zdrowy rówieśnik. Okazjonalnie zdarza się, że instamatka pokazuje syna lub córkę trzymających w ręku inhalator. Próżno szukać natomiast w postach ujęć, na których fotograf uchwyciłby moment podawania dziecku środków farmaceutycznych - zazwyczaj obfitujący w negatywne emocje dla obu uczestniczących w nim stron - czy płacz lub rozdrażnienie chorego spowodowane złym samopoczuciem. Powszechna jest też całkowita rezygnacja z aktywności na Instagramie w czasie niedyspozycji dziecka. Instamatka znika wtedy z Sieci i dopiero, gdy sytuacja rodzinna jest już opanowana, a życie wróciło na dawne tory, informuje - mniej lub bardziej wyczerpująco - o tym, co się działo, i tym samym tłumaczy swoją nieobecność w wirtualnym świecie. Jeszcze inny scenariusz postępowania, który wykorzystują instamatki do informowania o trudnych momentach swojej codzienności, zakłada publikację jedynie krótkiej wzmianki w chwili pojawienia się różnego rodzaju problemów zwykle zdrowotnych. Pokazywane wtedy zdjęcie jest często kadrem z przeszłości. Obraz w żaden sposób nie wiąże się tematycznie z aktualną niekomfortową sytuacją matki, dziecka i całej rodziny. Jedynie opis, który mu towarzyszy, zawiera informację o tym, z czym mierzy się obecnie właścicielka profilu i jej najbliżsi. $\mathrm{W}$ poniedziałkowy ranek instamatka, zamieszcza np. zdjęcie $\mathrm{z}$ weekendowego spaceru z dzieckiem, a obok pojawiają się hasztagi \#choredziecko, \#chorobaniewybiera, \#choroba, \#wirus, \#nieprzespananoc.

Niekiedy przekaz dopełnia jeszcze krótki film zamieszczony na instastories, w którym internautka informuje o swojej trudnej sytuacji, zapowiada nieobecność w Sieci i prosi obserwatorów o wyrozumiałość. Tego rodzaju wpisy wywołują zwykle silne sprzężenie zwrotne u odbiorców. W komentarzach wyrażają oni swoje wsparcie i dzielą się radami, które mogą okazać się pomocne w przezwyciężaniu problemów zdrowotnych.

Chęć niesienia pomocy przez członków wspólnoty komunikacyjnej instamatek oraz potrzebę jej otrzymywania przez właścicielki profili, daje się zaobserwować jednak nie tylko w przypadku choroby dziecka. Kobiety, które są tu aktywne, doradzają sobie niemal we wszystkich kwestiach dotyczących wychowania dziecka, rozwiązywania problemów życia codziennego oraz dokonywania mniej lub bardziej poważnych wyborów życiowych.

Pisząc o obrazie świata kreowanego w postach instamatek, koniecznie należy też wspomnieć jeszcze jedną ważną cechę, która go charakteryzuje: żartobliwy 
sposób przedstawiania negatywnych doświadczeń związanych z macierzyństwem. W opisach zdjęć i dodawanych do nich hasztagach nie ma miejsca na wyrażanie frustracji czy zniecierpliwienia spowodowanego powtarzalnością czynności towarzyszących opiece nad niemowlęciem. Skrajnie zmęczona brakiem snu lub ilością obowiązków instamatka pokazuje zdjęcie swojego uśmiechniętego dziecka i tylko między słowami lub, używając metafor, wspomina o trudnościach, z którymi się boryka. Równocześnie jednoznacznie informuje, że możliwość obcowania z małym człowiekiem, jego bliskość i sam fakt jego istnienia wynagradzają jej wszystko, z czym musi się zmierzyć.

Podobnie jak w przypadku dzielenia się informacjami o chorobie dziecka, tak i w sytuacji pojawienia się innych problemów instamatka często decyduje się na przemilczenie sprawy lub tylko jej delikatne wspomnienie. W taki właśnie oszczędny sposób relacjonuje się np. na początku aktywności na Instagramie trudności w karmieniu piersią i przeżywanie depresji poporodowej, później - problemy w rozszerzaniu diety i wątpliwości związane z prawidłowością rozwoju dziecka; następnie - kłopoty z adaptacją w żłobku czy negatywne doświadczenia związane z poszukiwaniem opiekunki, wreszcie - najróżniejsze problemy wychowawcze. Co ciekawe: nawet te zdawkowe informacje o problemach zawsze wywołują w odbiorcach żywe reakcje i motywują ich do udzielania kobiecie werbalnego wsparcia oraz wyrażania zrozumienia dla trudnej sytuacji, w której się znajduje.

Mając na uwadze powyższe obserwacje, można uznać, że w swoich przekazach instamatki dokonują regularnej manipulacji. Tak należałoby określić ich działania, odwołując się np. do stwierdzeń profesora Jerzego Bralczyka. Uważa on, że w kontakcie językowym jednostronnym i zapośredniczonym, charakterystycznym dla sytuacji medialnych, za manipulację można uznać (i może nią być) zarówno selekcjonowanie i porządkowanie zdarzeń i informacji, jak i pomijanie niektórych argumentów przy eksponowaniu innych (... ${ }^{13}$. Wybiórczość prezentowanych obrazów i treści na tyle silnie daje o sobie znać w instagramowej komunikacji omawianej społeczności, że można ją wręcz uznać za cechę definicyjną tworzonych i rozpowszechnianych tu przekazów.

Instamatki tworząc swój wirtualny pamiętnik dobrych wspomnień, budują obraz macierzyństwa dość mocno odbiegający od standardów prawdziwego

${ }^{13}$ J. Bralczyk, Manipulacja językowa [w:] „Dziennikarstwo i świat mediów”, red. Z. Bauer, E. Chudziński, Wydawnictwo Universitas, Kraków 2004, s. 244-250. 
życia. Pokazywany przez nie świat nie jest dotknięty chaosem, o którym tak często mówią kobiety doświadczające macierzyństwa. Na pierwszy plan w przekazach wyłania się radość z bycia matką. Pojawienie się dziecka nie jest tutaj destabilizujące ani nadmiernie obciążające. \#Instamatka, owszem, jest mocno zaabsorbowana swoją nową życiową rolą, ale komunikuje to odbiorcom w taki sposób, by byli przekonani, że dokonało się w niej istotne przewartościowanie priorytetów i pragnień. To właśnie ta zmiana pozwala jej odnajdywać się w nowej rzeczywistości, a także motywuje do dzielenia się nieznanymi dotąd doświadczeniami z innymi członkami społeczności.

W kontekście opisanych już spostrzeżeń nietrudno stwierdzić, że dziecko jest niekwestionowanym centrum instamatkowego wszechświata. Błędem byłoby jednak niezwrócenie uwagi na posty, w których kobiety na pierwszym miejscu stawiają siebie. Jest ich zdecydowanie mniej niż tych poświęconych dziecku, ale w kontekście poszukiwania odpowiedzi na pytanie, co jest ważne dla instamatek, są one bardzo ważne. W tych przekazach dominują informacje o sukcesach w utarcie wagi i powrocie do figury sprzed ciąży, doniesienia o samotnym (nie w towarzystwie dziecka) wyjściu na zakupy czy realizacji drobnych marzeń spotkanie z koleżankami, znalezienie wolnej chwili na oddanie się ulubionemu hobby. Instamatka nie dzieli się z publicznością dyskomfortem związanym z ograniczeniem możliwości prowadzenia życia towarzyskiego. Zamiast wyrazów żalu nad tym, co utracone, na jej profilu znajdzie się opis radości towarzyszącej temu, co udaje się robić w nowych warunkach.

Tylko czasami instamatka pokazuje na profilu swoje słabości i niedoskonałości. Wśród postów oznaczonych hasztagiem \#instamama rzadko można znaleźć zdjęcie nieuporządkowanej przestrzeni domowej - stosu ubrań czekających na uprasowanie, zabawek rozrzuconych po mieszkaniu czy piętrzących się w zlewie brudnych naczyń. Nie ma tu wprawdzie deklaracji bycia perfekcyjną panią domu, ale jako że instamatka dużo chętniej chwali się swoimi sukcesami niż dzieli porażkami, to nawet w postach, w których z opisu wynika, że sprzątanie nie jest ulubioną czynnością autorki, zwykle pojawia się zdjęcie wnętrza, któremu trudno zarzucić nieład. Towarzyszy mu zazwyczaj informacja o tym, że instamatce właśnie udało się zmotywować do porządków i to, co widać na fotografii, to efekt jej ciężkiej pracy.

Większość instamatek to zdeklarowane estetki. Są na bieżąco przede wszystkimi z trendami dotyczącymi przedmiotów codziennego użytku i gadżetów 
związanych z wychowaniem dziecka. Dbają o to, by ich dzieci były modnie ubrane, bawiły się zabawkami z najnowszych kolekcji znanych marek i przebywały we wnętrzach urządzonych specjalnie $\mathrm{z}$ myślą o nich. Informowanie o tym, jak będzie wyglądała przestrzeń zaaranżowana dla dziecka instamatki zaczynają zazwyczaj jeszcze w czasie ciąży. To wtedy pokazują kolejne elementy gromadzonej wyprawki. Piszą o tym, czego jeszcze im brakuje, aby być gotową na przyjście dziecka na świat.

Wiele z nich bardzo starannie dokumentuje też sam przebieg ciąży. W tym celu publikują posty z wiadomościami podawanymi przez specjalne aplikacje telefonicznych, które w każdym tygodniu ciąży informują użytkowniczkę o kolejnych etapach życia płodowego jej dziecka i jego rozwoju. Obserwatorzy dowiadują się z nich, ile waży i mierzy płód, co już potrafi robić i ile dokładnie dni pozostało do porodu. Aplikacje, o których mowa dostarczają ciężarnej informacji co tydzień, ale rzadko która instamatka udostępnia je w Sieci z taką właśnie częstotliwością. Najczęściej komunikat pojawia się w tych momentach trwania ciąży, które z jakichś powodów są uznawane za ważne - np. wtedy, gdy rozpoczyna się kolejny trymestr życia płodowego dziecka, mija połowa czasu oczekiwania na poród czy w momencie, gdy ciężarna zaczyna zauważać wyraźne oznaki ciąży na ciele.

Analizując posty instamatek, można też stwierdzić, że ważnym obszarem ich aktywności jest bycie na bieżąco z trendami mody. Kobiety pokazują np. zdjęcia lub krótkie filmy robione podczas zakupów w sklepach odzieżowych i proszą obserwatorów o radę dotyczącą wyboru przymierzanych ubrań. W opisach postów tego rodzaju powtarzają się informacje o konieczności wymiany garderoby, bo kobieta czuje, że poświęca zbyt mało uwagi wyglądowi lub świętuje w ten sposób sukcesy w odchudzaniu. Instamatki, które mają córki (niezależnie od ich wieku), chętnie kompletują jednakowe zestawy ubraniowe dla nich i dla siebie, a społeczność zawsze bardzo pozytywnie reaguje na zdjęcia oznaczone hasztagiem \#matchymatchy, czyli pokazujące dorosłego i dziecko (również całe rodziny) w dopasowanych stylizacjach.

Instamatka to również kobieta, która stosunkowo dużo uwagi poświęca tematyce kulinariów - przede wszystkim diecie dziecka. Wśród postów znajduje się wiele takich, na których widać dania przygotowywane dla niemowlęcia. Niektóre matki dzielą się także przepisami na nie. $\mathrm{W}$ opisach fotografii częste są pytania zadawane innym użytkowniczkom o to, gdzie kupują składniki na posiłki dla dzieci. W tym kontekście poruszane są kwestie dotyczące ekożywności i produktów 
naturalnych. Co ciekawe, mimo że najpopularniejsze \#instamatki reklamują wiele produktów przeznaczonych dla dzieci, wśród nich rzadko znajduje się gotowa do spożycia żywność. Kobiety zdecydowanie chętniej pokazują tutaj własnoręcznie przygotowane dla niemowlęcia posiłki.

Nawiązując jeszcze do działalności zarobkowej \#instamatek, warto zauważyć, że nie tylko podejmują one współpracę z reklamodawcami, ale także traktują platformę Instagramu jako przestrzeń do uruchamiania własnych przedsięwzięć o charakterze komercyjnym. Część z nich po zakończeniu urlopu macierzyńskiego rezygnuje z dotychczasowej aktywności zawodowej i rozpoczyna własną działalność gospodarczą. Instagram jest jednym z ważniejszych kanałów komunikacyjnych, na których nowo powstające firmy są przez instamatki promowane. Przedsięwzięcia, które podejmują kobiety, najczęściej związane są ze sprzedażą i szeroko pojętą branżą lifestyle'ową. Zakłada się nowe marki odzieżowe, biżuteryjne, elementów wyposażenia wnętrz i akcesoriów domowych oraz tzw. luksusowych gadżetów. Członkowie wirtualnej społeczności skupionej wokół profilu są często pierwszymi odbiorcami komunikatów o pracach nad uruchomieniem firmy, a później stają się odbiorcami oferowanych do sprzedaży produktów.

\section{WARTOŚCI WAŻNE DLA INSTAMATEK}

Odwołując się do teorii społecznego determinowania kodu Basila Bernsteina ${ }^{14}$, można założyć, że wartości przyjęte i akceptowane przez określone jednostki ujawniają się w ich językowym sposobie przedstawiania rzeczywistości. Teza ta stwarza podstawę do próby nakreślenia systemu wartości danej grupy poprzez analizę zasobu leksykalnego, jakim się ona posługuje.

Dla potrzeb niniejszych rozważań przyjmuję za właściwą definicję wartości ze Słownika języka polskiego, zgodnie z którą wartość to cecha lub zespół cech właściwych danej sobie lub rzeczy, stanowiących o jej walorach (moralnych, artystycznych), cennych dla ludzi, mogących zaspokoić jakieś ich potrzeby, ważność, znaczenie dla kogoś, czegoś ${ }^{15}$.

Wyróżniamy dwa zasadnicze rodzaje wartości:

${ }^{14}$ http://essa.ie.ulisboa.pt/ficheiros/teoriabb_eng/bernsteinstheory_textprint.pdf

${ }^{15}$ Słownik języka polskiego, red. prof. M. Szymczak, PWN, Warszawa 1981, tom III, str. 660. 
1. wartości pozytywne

2. wartości negatywne.

Dają one podstawę czynności psychicznej, jaką jest przypisywanie cechom, zachowaniom, stanom, a w efekcie ludziom i przedmiotom, ładunku wartościującego. Ten proces nosi nazwę wartościowania i polega na stwierdzaniu, jakie i w jakim stopniu wartości pozytywne i negatywne są właściwe, zdaniem osoby wartościującej, wymienionym wyżej obiektom ${ }^{16}$.

Różnorodność wartości wskazywanych w licznych typologiach narzuciła konieczność dokonania wyboru co do tego, które z nich będą brane pod uwagę w podejmowanych analizach. Odwołując się do podziałów dokonanych w tym zakresie przez Jadwigę Puzyninę, zadecydowałam, że przedmiotem rozważań będą wartości deklarowane przez instamatki (z pominięciem trudnych do uchwycenia wartości uznawanych czy odczuwanych, a także instrumentalnych i ostatecznych), a do ich wyodrębnienia posłuży analiza wypowiedzi publikowanych na Instagramie postów oraz dodawanych do nich hasztagów. W obszarze moich zainteresowań znalazły się więc:

- językowe środki wartościowania o charakterze skonwencjonalizowanym

- językowe środki wartościowania o charakterze fakultatywnym

Mając na uwadze specyfikę komunikacji za pośrednictwem Instagramu, zwracam także uwagę na niektóre parajęzykowe środki wartościujące używane przez członkinie omawianej społeczności - związane np. z symboliką graficzną.

Obserwacji i analizie zostały poddane posty oznaczone hasztagami \#instamama i \#instamatki, pojawiające się w Sieci od lutego do czerwca 2019 roku. W tym okresie średnio raz na 3 do 5 dni dokonywany był przegląd publikacji oznaczonych we wspomniany wyżej sposób. Najczęściej powtarzające się hasztagi i motywy poruszane w opisach zdjęć posłużyły do wyodrębnienia kilku najważniejszych dla \#instamatek wartości.

\section{DZIECKO PRZEDE WSZYSTKIM}

O tym, że dziecko jest dla \#instamatki najwyższą wartością, świadczą zarówno opisy zdjęć, jak i dodawane do nich hasztagi.

${ }^{16}$ J. Puzynina, Język wartości, Wydawnictwo Naukowe PWN, Warszawa 1992, s. 83. 
Jako te najbardziej wymowne w przekazie, jednoznacznie wyrażające emocje i uczucia kobiet, wskazałbym:

- \#jestembojestes

- \#mylove

- \#mojemilosci

- \#mojewszystko

- \#mojeszczescie

- \#purelove

- \#sleepingbeauty

- \#sercamamdwa

- \#sercepodsercem

- \#momlifeisthebestlife

- \#kochamnadzycie.

Są one dodawane przede wszystkim do zdjęć, na których w centrum uwagi znajduje się dziecko, ale także do fotografii rodzinnych czy zdjęć dokumentujących przebieg ciąży. Wynika z nich nie tylko deklaracja matczynej miłości i szczęścia płynącego z doświadczania macierzyństwa. Fraza „jestem bo jesteś” pozwala wręcz myśleć o pewnej zmianie tożsamości, która dokonuje się w kobiecie stającej się matką. W tym kontekście wcale nieprzesadzone wydaje się stwierdzenie, że pojawienie się dziecka nadaje nowy sens istnieniu kobiety, skłania do przewartościowania priorytetów, znajdowania pozytywnych doznań w nieznanych dotąd sferach życia.

Podobne wnioski można wyciągnąć, spoglądając na dłuższe opisy tekstowe zdjęć $^{17}$ :

- Tyyyyyle radości daje mamusi ta mała panienka ${ }^{18}$

- Miłość z rana ${ }^{19}$

- Trochę cukru z rana ${ }^{20}$

- L.: Mamuś, a czy ja jestem piękna?

Ja: Oczywiście, że jesteś piękna.

L.: A czy ja jestem Łobuz?

${ }^{17}$ Cytowane w artykule opisy mają oryginalny zapis i zawierają także emotikony oraz inne znaki graficzne używane przez autorki.

${ }^{18}$ https://www.instagram.com/marta.kaminska/ (dostęp: 14.10 .2019 r.)

${ }^{19} \mathrm{https}$ ://www.instagram.com/mum_armin/ (dostęp: 14.10.2019 r.)

${ }^{20}$ https://www.instagram.com/wonderwo.mum/ (dostęp: 14.10.2019 r.) 
Ja: Czasem kochanie zdarza Ci się coś spsocić. :-

L.: Czyli jestem piękny Łobuz, tak? (-) bo Liwka to jest tylko Łobuz Tia i jak tu ich nie kochać, tych moich „pięknych łobuzów” dwóch... ${ }^{21}$

- Uśmiech dziecka najcenniejszy, najwspanialszy, najszczerszy $\bullet$ Zazdroszczę że dzieci cieszą się z najmniejszych rzeczy $\odot^{22}$.

Dziecko jest obiektem uwielbienia instamatki. To ono sprawia, że kobieta odnajduje w życiu codziennym powody do radości (a przynajmniej deklaruje, że tak się dzieje), że z optymizmem oddaje się czynnościom, które stają się obowiązkami, gdy jest się matką. Dziecko skłania kobietę do łagodzenia pewnych odczuć. Złość czy zniecierpliwienie słabną w obliczu doświadczania bezgranicznej i bezwarunkowej miłości.

\section{CZAS Z RODZINA}

Analizując posty instamatek, można odnieść wrażenie, że ich czas jest odmierzany kolejnymi weekendami. Duże znaczenie i wręcz nieocenioną wartość ma dla nich piątek. Dają temu wyraz, używając następujących hasztagów i opisów ${ }^{23}$ :

- piąteczek

- piątunio

- byle do piątku

- jutro piątek

- piątek

- nareszcie piątek

- koniec tygodnia.

Instamatki wyraźnie czekają na weekend. To wtedy mają okazję spędzić więcej czasu z partnerem - ojcem dziecka i cieszyć się bliskością rodziny. To co nazywają i oznaczają \#familytime, to ich zdaniem cel, do którego się dąży. Dowodzą tego hasztagi opisujące zdjęcia z najbliższymi, ale też dalszymi krewnymi:

- \#razem najlepiej

- \#nareszcie razem

- \#wspólny czas

${ }^{21}$ https://www.instagram.com/edka_i_ferajna/ (dostęp: 14.10 .2019 r.)

${ }^{22}$ https://www.instagram.com/mama_i_mikrusek/ (dostęp: 14.10.2019 r.)

${ }^{23}$ Powszechne jest, że hasztagi różnią się od opisów zdjęć jedynie zapisem. Ich treść często bywa zbieżna. 
- \#czasdlarodziny

- \#razemnawetnakniecswiata

- \#senszycia.

Podobne w wyrazie przekazy zawarte są także w opisach zdjęć rodzinnych:

- Piękny czas ${ }^{24}$

- Słodziaki moje $\mathrm{e}^{25}$

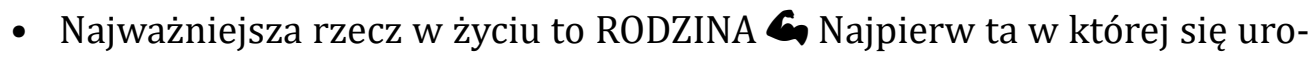
dziłeś, później ta którą sam stworzyłeś ${ }^{26}$.

Co ważne w tym kontekście, ojciec dziecka pojawia się rzadko. Mężczyzna jest pokazywany na zdjęciach raczej okazjonalnie, choć kobieta wspomina o nim w opisach. Przy kolejnym poście publikowanym w tygodniu informuje np., ile czasu spędzi danego dnia sama z dzieckiem, czekając na powrót partnera z pracy. Możliwość spędzania czasu z nim i dzieckiem to pewnego rodzaju święto w codzienności instamatki.

\section{CZAS DLA SIEBIE}

Deklarowane pełne zaangażowanie instamatki w życie i obowiązki rodzinne nie wyklucza się z jej potrzebą znalezienia czasu na odpoczynek. Synonimem luksusu i powodem do radości, o którym pisze na różne sposoby, jest możliwość wypicia ciepłej kawy. Ten motyw pojawia się w wielu postach. Kobiety informują się np. o tym, czy w danym dniu udało im się już dokonać wyczynu, za który uznają możliwość delektowania się ulubionym napojem, zanim stanie się on zimny i niesmaczny.

Hasztagi najczęściej pojawiające się przy zdjęciach, na których autorki pokazują swój ceremoniał picia kawy, to:

- \#kawusia

- \#czasnakawę

- \#kawka

- \#pleasuretime

- \#coffeevibes

${ }^{24}$ https://www.instagram.com/nieperfekcyjnamama/ (dostęp: 14.10.2019 r.)

${ }^{25}$ https://www.instagram.com/agussia_s/ (dostęp: 14.10.2019 r.)

${ }^{26}$ https://www.instagram.com/martina.banas/?hl=id (dostęp: 14.10.2019 r.) 
- \#coffeecup

- \#kawazrana.

W opisach zdjęć można z kolei znaleźć m.in. takie stwierdzenia jak:

- Pora na chwilę przerwy Kawusia obowiązkowo w kubeczku ${ }^{27}$

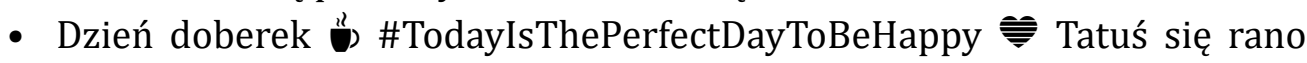
zajął kurczakiem a mama pospala do 9! (...) Co by nie było - najpierw kawa है: 28

- Idealne poranki, to takie które spędzamy razem. Codziennie rano z mężem wspólnie pijemy kawkę. Bobas wtedy zajada śniadanie, lub bawi się, a my mamy czas żeby się rozbudzić. $(. . .)^{29}$.

Dla instamatki chcącej znaleźć \#czasdlasiebie podwodem do radości jest też sen dziecka. Popularne hasztagi opisujące zdjęcia z obrazami tego rodzaju to:

- \#spiacedziecko

- \#sleepingbeauty

- \#dzieckośpi

- \#karaluchypodpoduchy

- \#drzemka.

Kiedy dziecko zasypia w ciągu dnia, matka może poświęcić się ulubionym czynnościom - czytaniu, pielęgnacji urody, rozwijaniu hobby. Z kolei poranny dłuższy sen niemowlęcia pozwala matce na lepszy wypoczynek i regenerację sił.

Oto kilka przykładów tego, jak o śnie swoich dzieci piszą instamatki:

Dostałam dzisiaj najpiękniejszy prezent od moich dzieci... obydwoje wstali po 9 . Prawdziwy prezent od serca, jakby wiedzieli czego dziś potrzebuje ${ }^{30}$

I oby ta noc była spokojna! ..bo ostatnio mamy istny maraton! wej wychodzą 5 ! dobrej nocki! ${ }^{31}$

Nie mogę się zmobilizować, pomimo głowy pełnej pomysłów. Potrzebuję solidnego kopa, albo dłuższych drzemek Kawalera.. $\mathrm{S}_{\mathrm{S}}^{3}{ }^{32}$

\footnotetext{
${ }^{27}$ https://www.instagram.com/sylvvia_trendovvicz/ (dostęp: 14.10.2019 r.)

${ }^{28}$ https://www.instagram.com/angela_skrobska/ (dostęp: 14.10.2019 r.)

${ }^{29}$ https://www.instagram.com/paula.myk/ (dostęp: 14.10.2019 r.)

${ }^{30}$ https://www.instagram.com/imdominikapolak/ (dostęp: 14.10.2019 r.)

${ }^{31}$ https://www.instagram.com/nasze_em/ (dostęp: 14.10 .2019 r.)

${ }^{32}$ https://www.instagram.com/guzik.prawda/ (dostęp: 14.10.2019 r.)
} 
Wartościowy \#czasdlasiebie członkinie społeczności instmatek wiążą również z możliwością wyjścia z domu, spotkania ze znajomymi, przebywania w gronie innych dorosłych bez obecności dziecka. Posty, w których relacjonują te przyjemności, oznaczają hasztagiem \#matkamawychodne. Na sklasyfikowanych w ten sposób fotografiach autorki zdecydowanie najczęściej pokazują to, jak wyglądają. Prezentują ubrania wybrane na te wyjątkowe okazje, starannie wykonane makijaże i fryzury. Wyjścia odbywają się zwykle w weekendy. W takim wypadku powszechne jest używanie hasztagu \#goraczkasobotniejnocy. Rzadziej, ale też się zdarza, że i w tygodniu kobieta spędza sama czas poza domem. Te wyjścia częściej mają jednak charakter służbowy i dotyczą kobiet z dłuższym stażem macierzyńskim, które wróciły już do aktywności zawodowej.

\begin{abstract}
Matka ma wychodne, czyli wyjście służbowe Dzisiejszy wieczór spędziłam z moimi kochanymi korpoludkami ${ }^{33}$

To był najlepszy weekend w świetnym towarzystwie. Najpierw bardzo fajnie spędziłam czas z dziewczynami na @targi_beauty_days (-) A później miałam okazje odkryć jeszcze nieodkryte miejsca w Warszawie. Bardzo dziękuje za ten weekend, czuje że był mi on potrzebny! ${ }^{34}$

Świetny weekend na Mazurach i regaty na Jez. Bełdany \#wyjazdintegracyjny ${ }^{35}$
\end{abstract}

Do aktywności podejmowanych przez instamatki „w czasie dla siebie” i dokumentowanych na Instagramie należy też zaliczyć dbałość o sylwetkę. W tym kontekście daje się zauważyć dwa najważniejsze trendy w prezentowanych postawach. Z jednej strony kobiety zachęcają się nawzajem do tego, by akceptować ciało bez względu na to jak wygląda po przebytych ciążach, a z drugiej - prowadzą nieustającą walkę o szczupłą figurę, odpowiadającą obowiązującym ich zdaniem kanonom piękna.

Hasztagi, które są najczęściej wykorzystywane w postach o tej tematyce, to:

- \#afterpregnancy

- \#postpartum

- \#(...)weekspospartum (ze wskazaniem na początku liczby tygodni, które upłynęły od porodu)

\footnotetext{
${ }^{33}$ https://www.instagram.com/odgorydodolu/ (dostęp: 14.10.2019 r.)

${ }^{34}$ https://www.instagram.com/caly_swiat_patrzy/(dostęp: 14.10.2019 r.)

${ }^{35}$ https://www.instagram.com/magdalenkamk/ (dostęp: 14.10.2019 r.)
} 
- \#fitmom

- \#fitmama

- \#fitmatka

- \#mamatrenuje

\section{(...) w kontekście wyglądu wartością dla instamatek jest panowanie nad własnym ciałem.}

Przyglądając się oznaczonym w ten sposób postom, można skłaniać się ku stwierdzeniu, że w kontekście wyglądu wartością dla instamatek jest panowanie nad własnym ciałem. Są dumne, jeśli niedługo po porodzie udaje im się zmotywować do ćwiczeń i podjęcia oraz utrzymania diety. To dla nich ważne, by publiczność widziała i doceniała starania, które podejmują, by być szczupłymi. Można wręcz mówić o tym, że relacjonowanie w Sieci procesu odchudzania to sposób na zapewnienie sobie wsparcia ze strony obserwatorów. Wsparcia społeczności oczekują też te kobiety, które mają problem z nadwagą i nie mogą sobie z nim poradzić. Dla nich ważne jest zrozumienie wyrażane przez inne instagramowiczki oraz wspólnotowe oswajanie niekorzystnych zmian w wyglądzie. Nie oznacza to jednak, że wykluczają podejmowanie starań o metamorfozę ciała. Przeciwnie: daje się zauważyć, że instamatki, które dłuższy czas po porodzie nie koncentrowały się na dążeniu do odzyskania szczupłej sylwetki, zaczynają to robić, kiedy dziecko jest starsze i mają więcej wolnego czasu. Wtedy też informują instagramową grupę bliższych i dalszych znajomych o swoich działaniach i dzielą się radością z osiąganych sukcesów.

W kontekście omawianego tematu warto jeszcze zwrócić uwagę na często powtarzający się w postach sposób pokazywania zmian, które dokonują się w wyglądzie kobiety. Instamatki chętnie zamieszczają zdjęcia z ostatnich tygodni, a nawet dni ciąży połączone z fotografiami zrobionymi już po porodzie. W ten sposób najłatwiej zobaczyć metamorfozę, którą przechodzą ich ciała - szczególnie, jeśli kobieta jest predysponowana do szybkiego odzyskiwania sylwetki sprzed ciąży. 
Pokazywanym na zdjęciach obrazom towarzyszą też stosowne opisy. Oto niektóre z nich.

Tym razem porównanie 9 i 14 dni po porodzie. Jest nieźle. Zwłaszcza biorąc pod uwagę fakt, że na razie moje jedyne ćwiczenia to aktywacja mięśni głębokich czyli poprzecznego brzucha i mięśni dna miednicy. ${ }^{36}$

37 tydzień ciąży vs 7 dni po porodzie W ciąży przytyłam jakieś $10-11 \mathrm{~kg}$, teraz waga wskazuje juz tylko 4 kilogramy więcej niż przed zajściem w ciążę, ale brzuszek jeszcze miękki i wygląda jak w 4 miesiącu@̂) (chociaż pod luźniejszymi ubraniami już go nie widać). Rósł 9 miesięcy, więc wiem, że nie wróci do swoich poprzednich rozmiarów w przeciągu tygodnia ${ }^{37}$

Dziś zdjęcie nie instagramowe Kiedyś bym wstydziła się dodać takie zdjęcie, dziś wiem, ze wstydzic bym się mogła gdybym nic z tym nie zrobiła ży $25 \mathrm{~kg}$, tego balastu już się całkiem prawie pozbylam, ale zostało jeszcze trochę i będę walczyć o to dalej, polubiłam cwiczenia, teraz jak mam kilka dni przerwy to jestem zła na siebie Wiele musi się zmienić w głowie bez tego nie warto zaczynać! A wszystko dzięki @monikolakowska z nią od czerwca zgubiłam 12kg

O tym, że \#czasdlasiebie jest dla \#instamatek wartościowy, przekonuje też akcja podjęta przez użytkowniczki omawianego medium w czerwcu 2019 roku. Wtedy to pojawiła się inicjatywa oznaczania zdjęć hasztagiem \#ajadzisdlasiebie. Na tak opisanych fotografiach kobiety pokazywały przyjemności, na które pozwoliły sobie danego dnia i zachęcały do tego samego inne użytkowniczki. Jak deklarowały w postach, miało to być motywacją do dbania o siebie i własne potrzeby. Oto, jak anonsowała akcję jedna z jej inicjatorek.

\#ajadzisdlasiebie - no właśnie, co ostatnio zrobiłaś tylko dla siebie - dziś, wczoraj lub tydzień temu? Pamiętaj, że Ty też się liczysz i nie możesz o tym zapominać! Zadbaj o siebie, zrób coś, co lubisz, dla swojego własnego szczęścia. My postaramy się trochę Ci w tym pomóc. W akcji, którą kontynuujemy będziemy starać się motywować Cię do działania, pokazać jakie to proste i jak zrobić te pierwsze kroki do szczęśliwszej wersji siebie. Zaglądaj do nas po inspirację i zacznij zmieniać swoje życie, zrób coś dla siebie!

\footnotetext{
${ }^{36}$ https://www.instagram.com/chicamala.pl/ (dostęp: 14.10.2019 r.)

${ }^{37}$ https://www.instagram.com/_fit_with_kid/ (dostęp: 14.10 .2019 r.)

${ }^{38}$ https://www.instagram.com/k.dziegiel/ (dostęp: 14.10.2019 r.)
} 
Znami:@mama_w_malym_miescie @zuz_inka_@amcialol @kasiazwolenik @mama_szkodnika@martaaand @oczamimami @paula_wiki_nela@xabell18

Dołącz do nas i akcji \#ajadzisdlasiebie - zrób coś dla siebie - kawa z koleżanką, wypad na siłownie, do fryzjera, relaks w wannie, czy z lekturą, a może odświeżenie garderoby? Pomysłów jest cała masa, inspiracji szukaj u nas. A kiedy już zrobisz coś dla siebie to napisz o tym, motywuj innych - wrzuć post lub stories koniecznie z hasztagiem \#ajadzisdlasiebie, żebyśmy mogli to zobaczyć! Jeśli chcesz możesz też nas oznaczyć - wtedy szybciej do Ciebie trafimy. ${ }^{39}$

Do października 2019 r. na Instagramie opublikowano 4033 postów opatrzonych hasztagiem \#ajadzisdlasiebie).

\section{USPRAWIEDLIWIENIE NIEDOSKONAŁOŚCI}

Poza trzema wymienionymi wyżej wartościami, które da się wyodrębnić na podstawie analizy postów instamatek, w ich publikacjach zwraca uwagę jeszcze jeden interesujący motyw, który można utożsamiać z wartościami.

Bycie niedoskonałą w co najmniej kilku obszarach aktywności - to kobiety dokumentujące macierzyństwo w Sieci uznają za swoje prawo, pewnego rodzaju wyznacznik autentyczności. Instamatki pokazują np. zdjęcie stosu prania, które czeka na uprasowanie i ułożenie w szafie i informują w jego opisie, że wolą poświęcić czas dziecku, niż zajmować się tą monotonną czynnością. Podobne „objaśnienia” pojawiają się przy zdjęciach (nielicznie występujących), na których widać bałagan panujący w mieszkaniach instamatek lub rodzinne spożywanie gotowych dań obiadowych. Pokazując te obrazy, instagramowiczka pisze w żartobliwym tonie, że daleko jej do perfekcyjnej pani domu, że obowiązki - nie zając - nie uciekną lub że danego dnia świętuje akurat dzień lenia, bo matce też się należy chwila wytchnienia.

Manifestacja zmęczenia rolą matki i pani domu pojawia się w postach wielu kobiet, ale z różnych natężeniem i przybiera różne formy. Najczęściej sposobem jego wyrażania jest właśnie wspomniany wyżej żartobliwy ton opisów zdjęć, jednak są i takie internautki, które dosłownie piszą o trudach macierzyństwa. Jedną z nich, prekursorką tego rodzaju aktywności w wirtualnym świecie matek, jest

${ }^{39}$ https://www.instagram.com/oczamimami/ (dostęp: 14.06.2019 r.) 
Natalia Rogalska, użytkowniczka o nicku matka_nie_idealna. Na jej profilu można znaleźć np. jednoznaczne w przekazie wyznanie treści pojawił się wtedy, gdy z powodu choroby dziecka kobieta długi czas spędziła z dziewczynką w domu i była tym bardzo zmęczona.

\section{Bycie niedoskonałą w co najmniej kilku obszarach aktywności - to kobiety dokumentujące macierzyństwo w Sieci uznają za swoje prawo (...)}

Sweet_fitness_mom w poście z 16 września 2019 roku zdała z kolei obszerną relację z tego, co przeżywa $\mathrm{w}$ związku z byciem mamą:

Ktoś tu chyba jest zmęczony $\odot$ tylko dlaczego po Małej Mi tego nie widać, a po mnie od razu ? ta mała cholera dzisiaj dała mi niezły wycisk i zastanawiam się, jak ja jeszcze daje radę funkcjonować , bo mój dzień zaczął się o 4.30 :iْì ale nie o tym chciałam mówić , choć to przedsmak tego co chcę rozwinąć...

Ostatnio Martyna @aktywna_mama napisała bardzo fajny post o tym , że my mamuśki wszystko potrafimy robić lepiej przy dziecku, ale też potrzebujemy czasu dla siebie i nie mamy się wstydzić prosić o pomoc . A właśnie, ile z Was tak ma ? :) Która potrafi się przyznać , że jest już zmęczona psychicznie i fizycznie , ma „dosyć ”, swojego dziecka i potrzebuje od niego „odetchnąć „. To calkiem normalne uczucie i nie powinnyśmy się wstydzić mówić o tym głośno ! to nie jest, że jesteś wyrodną matką, która nie kocha swojego dziecka . Nie można tego ukrywać i pokazywać , że niby wszystko jest w porządku . Ja mam takie dni , że najchętniej oddałabym Mię na tydzień i wyjechała na bezludną wyspę by być sama ze sobą, bez kitu na 102 , nie ma co 100 metrów za domem , dwa po ziemią ahahahaha Mijucha ma dopiero niecałe 5 miesięcy, a co z resztą czasu ? ja się cieszę , jak mogę w spokoju jechać do miasta zrobić zakupy i nie mam jej na karku, posprzątać czy zrobić cokolwiek w domu . Mimo wszystko i tak nie daje mi spokoju fakt, że zostawiam Mię z ciocią czy babcią, bo skubana nie chce pić mleka z butelki i mój czas wolności jest moco ograniczony $q$ \& $q$ cóż , łudzę się tym, że Mia lubi jeść , poznawać nowe 
smaki i tylko czeka na inną szamkę niż cyc , ale jednak bardzo to lubi i jest niezastąpiony ... A jak to jest u Was \#instamateczki ? $-{ }^{40}$

Opis pojawił się przy zdjęciu, na którym widać kobietę z niemowlęciem. Dziecko jest na pierwszym planie i zasłania część twarzy matki. Kobieta delikatnie się uśmiecha.

Uśmiech widać także na twarzy innej instamamy - Klaudii Skalskiej, która przy zdjęciu z dwojgiem swoich dzieci (z czerwca 2019 r.) pisze o towarzyszącym jej skrajnym zmęczeniu i konieczności sprostania społecznym oczekiwaniom, które stawia się matkom.

Macierzynstwo nie wygląda zawsze tak pieknie, jak te wszystkie cudne zdjecia na instagramie... Jest to dla każdej matki piekny a zarazem ciezki czas.. Macierzynstwo to trudna rola której trzeba sie nauczyć. Bycie mama nie jest łatwe i nie jest na chwile.. Ludzie którzy nas otaczaja, oczekuja od nas ze mama bedzie w 100\% dla dziecka.. Ale pamietajmy że warto a nawet trzeba walczy o przestrzen dla siebie. Bo nie jestemy tylko mamami ale tez kobietami , żonami, siostrami i warto o tym pamietac! . a Wy \#Mamuski co o tym myślicie? co dla was znaczy macierzystwo? jesteście tylko dla dzieci czy dla siebie też?

Milego dnia w Piatek-2 (lubie to zdjęcie widać na nim jak bardzo potrzebuję snu(-)

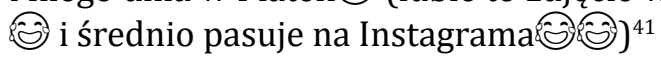

\section{MOŻLIWOŚCI KONTRA OCZEKIWANIA - PODSUMOWANIE}

Mając na uwadze opisane wyżej zjawiska, można wnioskować, że mimo iż w obrazie macierzyństwa kreowanym przez instamatki dominuje jego bardzo optymistyczna wizja, kobietom nie są obce również negatywne emocje związane z koniecznością sprostania tej wymagającej roli. Dziecko bezsprzecznie jest dla nich priorytetem - do tego stopnia, że na co dzień pokazują wyłącznie „udane” kadry z rzeczywistości. Możliwe, że w pewnym stopniu decyduje o tym również wspomniane poczucie presji społecznej, która niejako nakazuje bycie matką idealną. Ani to, ani pokazywanie na zdjęciach najlepszych ujęć z dzieckiem nie sprawia jednak, że macierzyństwo - choć zwykle upragnione i oczekiwane - staje się

${ }^{40}$ https://www.instagram.com/sweet_fitness_mom/ (dostęp: 14.10 .2019 r.)

${ }^{41}$ https://www.instagram.com/skalska_claudia_91/ (dostęp: 14.10.2019 r.) 
łatwiejsze. Będąc w wirtualnej łączności z innymi kobietami w podobnej sytuacji, instamatki starają się pozyskać wsparcie i budować więzi, których w realnym świecie nie są w stanie utrzymać na satysfakcjonującym poziomie ze względu na konieczność poświęcenia się dziecku.

\section{„(...) w obrazie macierzyństwa kreowanym przez instamatki dominuje jego bardzo optymistyczna wizja (...)"}

Odnosząc się jeszcze do wyjątkowo kolorowego obrazu macierzyństwa, który wyłania się z publikacji instamatek, warto poczynić krótką refleksję nad oceną ich działań. Mimo iż mają one znamiona pewnego rodzaju manipulacji i przekłamywania doświadczeń, niesłuszne byłoby ich napiętnowanie. Można bowiem uznać, że działającym w ten sposób kobietom zależy na pozytywnym postrzeganiu przez odbiorców, na przekonywaniu - również siebie samych - że w tej trudnej roli można się sprawnie odnajdywać i że dziecko rekompensuje każdy podejmowany dla niego trud.

Na pozytywną ocenę zasługuje także to, że instamatki cieszą się wzajemnie ze swoich sukcesów na różnych polach, wspierają w chwilach słabości i motywują do dbania o własny komfort psychiczny, który w szerszej perspektywie pomaga budować harmonijne relacje $\mathrm{z}$ bliskimi.

\section{BIBLIOGRAFIA}

Bralczyk J., Manipulacja językowa [w:] „Dziennikarstwo i świat mediów”, red. Z. Bauer, E. Chudziński, Wydawnictwo Universitas, Kraków 2004, s. 244-250.

Buczek P., Instagram jako miejsce komunikacji wizualnej mediów z odbiorcami [w:] „Naukowy Przegląd Dziennikarski" 2017, nr 4, s. 131-141.

Clayton L., Are there Virtual Communities? http://www.abdn.ac.uk/philosophy/endsandmeans/vol2no1/clayton.shtml.

Grabias S., Język w zachowaniach społecznych, Wydawnictwo Uniwersytetu Marii Curie-Skłodowskiej, Lublin 2003, s. 113.

Grzenia J., Komunikacja językowa w Internecie, Wydawnictwo naukowe PWN, Warszawa 2006, s. 43.

Puzynina J., Język wartości, Wydawnictwo Naukowe PWN, Warszawa 1992, s. 83. 
Rheingold H., The Virtual Community: Homestanding on the Electronic Frontier. Reading, MA: Addison-Wesley, 1993.

Sadowski M., Rewolucja social media, Gliwice 2013, s. 102.

Slouvka M., War of the Worlds: the assault on reality, London: Abacus, 1996.

Szpunar M., Społeczności wirtualne jako społeczności - próba ujęcia socjologicznego, [w:] „Jednostka-grupa-cybersieć. Psychologiczne, społeczno-kulturowe i edukacyjne aspekty społeczeństwa informacyjnego, red. M. Radochoński, B. Przywara, Rzeszów, WSIiZ, 2004, s. 157-184.

Wadhwa A, Kotha S., Research Associate Anu Wadhwa, University of Washington, 1999. http://us.badm.washington.edu/kotha/internet/handouts/vc5.PDF.

Słownik języka polskiego, red. prof. M. Szymczak, PWN, Warszawa 1981, tom III, str. 660. http://essa.ie.ulisboa.pt/ficheiros/teoriabb_eng/bernsteinstheory_textprint.pdf.

\section{Źródła}

https://www.instagram.com/agussia_s/

https://www.instagram.com/angela_skrobska/

https://www.instagram.com/caly_swiat_patrzy/

https://www.instagram.com/chicamala.pl/

https://www.instagram.com/edka_i_ferajna/

https://www.instagram.com/_fit_with_kid/

https://www.instagram.com/guzik.prawda/

https://www.instagram.com/imdominikapolak/

https://www.instagram.com/k.dziegiel/

https://www.instagram.com/magdalenkamk/

https://www.instagram.com/mama_i_mikrusek/

https://www.instagram.com/matka_nie_idealna/

https://www.instagram.com/marta.kaminska/

https://www.instagram.com/martina.banas/?hl=id

https://www.instagram.com/mum_armin/

https://www.instagram.com/nasze_em/

https://www.instagram.com/nieperfekcyjnamama/

https://www.instagram.com/oczamimami/

https://www.instagram.com/odgorydodolu/

https://www.instagram.com/paula.myk/

https://www.instagram.com/skalska_claudia_91/

https://www.instagram.com/sweet_fitness_mom/

https://www.instagram.com/sylvvia_trendovvicz/

https://www.instagram.com/wonderwo.mum/ 


\section{Biogram}

Marta Jarosz - doktor nauk humanistycznych w zakresie nauk o polityce, adiunkt w Instytucie Edukacji Medialnej i Dziennikarstwa UKSW w Warszawie, redaktorka portalu dziennik.pl i dziennikarka „Magazynu Dziennika Gazety Prawnej”, badaczka języka nowych mediów, pasjonatka szeroko pojętej problematyki społecznej, laureatka II edycji konkursu dla dziennikarzy „Uzależnienia XXI wieku”. 


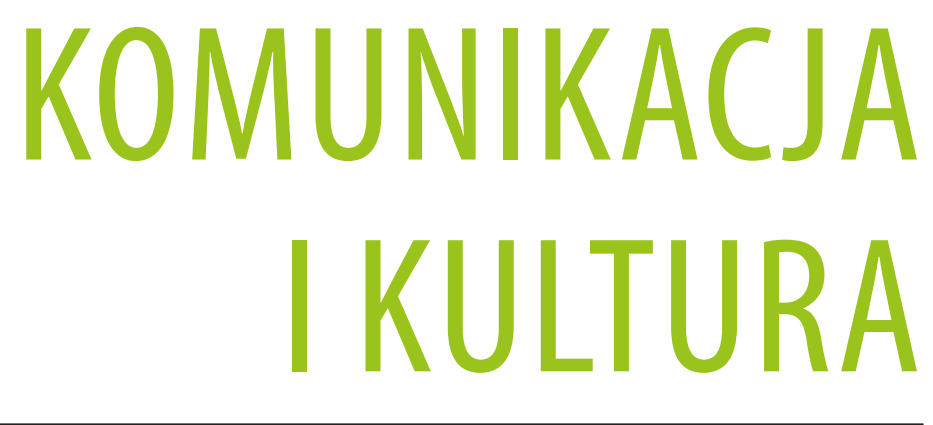

KULTURA - MEDIA - TEOLOGIA 39/2019 


\title{
Witold Wołowski ${ }^{1}$, Renata Jakubczuk ${ }^{2}$
}

'Université Catholique de Lublin Jean-Paul II

${ }^{2}$ Université Maria Curie-Skłodowska, Lublin

\section{La fiction peut-elle être réaliste ? Deux visions théâtrales du supermarché : Le Grand Chariot de Jacky Viallon (1993) et Bonzy, la vie, mort ou vif d'Alain Cofino Gomez (2013)}

\author{
Can fiction be realistic? Two theatrical visions \\ of the supermarket: Le Grand Chariot by Jacky Viallon (1993) \\ and Bonzy, la vie, mort ou vif by Alain Cofino Gomez (2013)
}

\begin{abstract}
RÉSUMÉ
La notion de réalisme en art et dans le théâtre n'est pas évidente aujourd'hui : la mimèsis purement réaliste n'a plus la même force d'attraction que par le passé, et les œuvres abordent des problèmes bien réels (psychologiques, sociaux, politiques etc.), sans correspondre à un modèle de représentation platement mimétique. On en vient à se poser une question essentielle: la fiction théâtrale, aujourd'hui, peut-elle vraiment se contenter

d'une esthétique réaliste (classique) ? Les travaux de différents chercheurs parlent, dans les dernières décennies, d'un réalisme élargi, non-mimétique. Nous souscrivons pleinement

à cette conception et, pour l'appuyer, nous analysons deux textes dramatiques strictement contemporains qui, tout en traitant des sujets éminemment réalistes (l'univers des grandessurfaces et des courses), reposent sur des modes de représentation qui renient, par la tonnalité comme par la forme, la mimèsis réaliste au sens stricte du terme. L'étiquette de réalisme est-elle alors toujours opérable ou faut-il reposer la question d'une autre manière?
\end{abstract}

MOTS-CLÉS:

réalité, théâtre, supermarché,

Viallon, Cofino Gomez

\section{ABSTRACT}

The notion of reality in art and theater is not obvious nowadays : the strictly realistic mimesis does not have the appealing power as it used to have in the past, and the theatrical works touch the real problems (psychological, social, political, etc.), without referring to a plainly mimetic model. It brings forth an essential question: can the theatrical fiction be satisfied by a realistic aesthetic (classical). In the last decades, the works of different researchers talk about expanded, non-mimetic reality. The authors of this article agree with this thesis, and in order to support it, they analyze two prominently realistic theater plays. While discussing prominently realistic subjects (the universe of shopping centers and shopping), the authors rely on the ways of representation, negate the very meaning of the notion of reality, whether by tonality or the form, the mimesis in its strictest sense. Should we still apply the label "realistic", or should we ask the question in a different way?

\section{KEYWORDS:}

reality, theater, supermarket, Viallon, Cofino Gomez 


\section{CZY FIKCJA MOŻE BYĆ REALISTYCZNA? \\ DWA TEATRALNE OBRAZY SUPERMARKETU: \\ LE GRAND CHARIOT JACKY'EIGO VIALLONA (1993) \\ I BONZY, LA VIE, MORT OU VIF ALAINA COFINO GOMEZA (2013) \\ STRESZCZENIE}

Pojęcie realizmu w sztuce i w teatrze nie jest dziś zbyt jasne: zwykła mimesis realistyczna utraciła już moc oddziaływania, jaką dysponowała w przeszłości, zaś konkretne dzieła dotykają bardzo realnych problemów (psychologicznych, społecznych, politycznych itp.), wcale nie podporządkowując się czysto mimetycznemu modelowi przedstawiania. Prowadzi to do postawienia fundamentalnego pytania: czy świat teatralnej fikcji może się dziś zadowolić (klasyczną) estetyką realizmu? Prace wielu badaczy mówią w ostatnich dekadach o realizmie rozszerzonym, nie-mimetycznym. Autorzy niniejszego artykułu zgadzają się w pełni z tą ogólną tezą i, dla jej ilustracji, analizują dwa stricte współczesne teksty dramatyczne, które podejmują bardzo realistyczne zagadnienia (świat hipermarketów i zakupów), oddalając się jednak tonalnie lub formalnie od mimesis realistycznej w ścisłym rozumieniu tego słowa. Czy zatem kategoria realizmu pozostaje wciąż opisowo skuteczna, czy całą kwestię należy postawić inaczej?

\section{SŁOWA KLUCZOWE:}

realizm, teatr, supermarket, Viallon, Cofino Gomez

Le théâtre n'est pas le pays du réel : il y a des arbres en carton, des palais de toile, un ciel de haillons, des diamants de verre, de l'or de clinquant, $d u$ fard sur la pêche, du rouge sur la joue, un soleil qui sort de dessous la terre. C'est le pays du vrai : il y a des cours humains dans les coulisses, des cœurs humains dans la salle, des cœurs humains sur la scène.

Victor Hugo (Tas de Pierres III 1830-1833)

Ma première idée était de démontrer que le réalisme au théâtre est nécessairement une grande illusion, et que lorsqu'on parle de réalisme, c'est toujours d'une tentative de réalisme qu'on parle, c'est toujours de degrés. Solange Lévesque (1997 : 53)

\section{UNE MISE EN OPTIQUE RAPIDE}

La catégorie esthétique du réalisme est sans doute l'une des plus délicates dans le domaine de la réflexion sur l'art. Elle suscite, depuis Platon ${ }^{1}$, des problèmes

${ }^{1}$ Nous pensons ici aux catégories connexes ou oppositionnelles face à celle du réalisme, à savoir diègèsis, mimèsis, dóxa, idéalisme, etc. Pour une discussion très instructive de ces deux premières notions, $c f$. Gaudreault (1999). Mais c'est surtout l'idée platonicienne du monde 
inextricables et probablement insolubles². Qu'est-ce, au fond, que le réalisme artistique ? «Utopie, paradoxe ou ingrédient essentiel » $?^{3}$ Une photographie du monde? Un calque discursif ou figuratif de ce que nous voyons autour de nous, au quotidien? Une représentation non dépaysante de l'univers empirique ? Un « diktat de la vraissemblance » ? Un point de vue matérialiste sur l'homme et son histoire ? Une esthétique qui bannit certains éléments (volitifs, oniriques, fantomatiques, romantiques, baroques, grotesques, expressionnistes, idéalistes...), en optant résolument pour d'autres (triviaux, terre-à-terre, sociologiques et politiques notamment) ? Y a-t-il un rapport entre le réalisme et la vérité ? les statistiques honnêtes ? le factuel ? l'état intersubjectivement vérifiable des choses ? Y a-t-il, encore dans le même ordre d'idées, une relation entre l'engagement social ou idéologique de l'art et le coefficient du réalisme qu'il affiche ? Enfin, qu'est-ce que l'imitation, l'illusion, la fiction artistique ? Peut-on les définir dans le monde qui est aujourd'hui le nôtre, où tout discours devient simplement une narration, en faisant de la vie une foire à fictions chaotique, dépourvue de sens et désintégrante $?^{5}$ Où réside donc ce que nous avons convenu d'appeler réalisme ? Toutes

matériel entendu comme un reflet d'un univers plus vrai et "réellement réel" (opposition entre óntōs ốn et le faux spectacle perçu par nos sens) qui semble fondamentale pour toute tentative d'une réflexion critique sur la réalité sensible qui nous entoure ou que l'on représente artistiquement, et qui se ramène souvent à une dóxa, c'est-à-dire à des croyances librement acceptées ou à des systèmes idéologiques plus ou moins contraignants et imposés. Ajoutons que les grandes conceptions de caractère religieux convergent en quelque sorte vers la même direction, mettant ouvertement en doute le primat du sensible sur le vrai, sans toutefois déboucher sur des conclusions identiques au niveau déontologique.

${ }^{2}$ « Grande illusion, en effet, que je puisse ajouter quoi que ce soit à ce sujet d'une complexité folle », écrivait Solange Lévesque déjà en 1997. Il se peut, en réalité, que tous les efforts entrepris pour cerner le problème soyent voués à l'échec dans la mesure où il est tout simplement mal posé, trop ample ou inexistant. Il est toutefois évident que l'histoire de l'art connaît une alternance (ou coexistence) des esthétiques adverses les unes par rapport aux autres qui réclament soit la fidélité, soit la liberté vis-à-vis des impératifs d'une vision réaliste des choses. Mais, entre la « scène sociale » et la « scène-laboratoire » (Carlotti $2014: 249$ ), il est souvent difficile de trancher laquelle est plus proche des préoccupations authentiques de l'individu.

${ }^{3}$ M. Vaïs, Questions sur le réalisme, « Jeu » 1997, 85, p. 42.

${ }^{4}$ J.-P. Sarrazac (dir.), Lexique du drame moderne et contemporain, Paris 2005, p. 175.

${ }^{5}$ Parler de réalisme dans la prétendue époque postmoderne (ou post-postmoderne...) semble quasi inutile, puisqu'en acceptant les prémisses idéologiques des courants post-intellectuels, on devrait admetre que l'humanité est en train de perdre pied sur tous les terrains et 
ces questions - et on pourrait en poser davantage - indiquent la compléxité de la problématique et l'immensité du terrain à prospecter ${ }^{6}$.

Malheureusement, les définitions disponibles de la notion qui nous intéresse ici ne vont pas au-delà des intuitions communes et ont souvent la faiblesse d'expliquer ignotum per ignotum : selon Pavis, le réalisme serait « une technique apte à rendre compte objectivement de la réalité psychologique et sociale de l'homme » ou à " doubler par la scène la réalité ${ }^{7}$, définition décevante dans la mesure où l'on ne sait toujours pas ce que c'est que réalité ${ }^{8}$. Sait-on d'ailleurs, aujourd'hui, ce que c'est que objectivisme et subjetivisme ? Le consus en la matière risque de faire problème. La vaste étude de Trancòn est un peu plus précise, puisqu'elle s'attache justement à la notion de la réalité (voir note 6), et sa conclusion est déjà un peu différente : « le réalime conjure les angoisses du monde extérieur » et il « agit en transformant la réalité ${ }^{9}$. C'est dans le même sens, celui de la transformation ou de "réévaluation de la mimèsis ${ }^{10}$, que s'avancent d'autres études récentes. Face aux œuvres littéraires et dramatiques modernes, les travaux évoqués dans le Lexique du drame moderne et contemporain dirigé par J.-P. Sarrazac (2005), parlent d'un réalisme élargi, mineur, non figuratif ${ }^{11}$. Sarrazac lui même propose le

qu'elle ne dispose plus de « récits de légitimation » (Kibédi Varga 1990 : 4) pouvant constituer une référence communément reconnue à un modèle de réalité unique.

${ }^{6}$ Il est intéressant de voir à cet égard l'impressionnant schéma proposé dans l'article de Santiago Trancón (Realidad y realismo en el teatro, «UNED. Revista » 2006, 15, p. 537) qui recence 4 types de réalités (totale, objective, transréelle et imaginaire) auxquels nous avons affaire dans notre expérience.

${ }^{7}$ P. Pavis, Dictionnaire du théâtre, Paris 2009, p. 285.

${ }^{8}$ "La réalité est un mot, rien qu'un mot, celui de réalité », écrit M. Mayer (Du romantisme au réalisme dans le théâtre, « Revue internationale de philosophie » 2011,1/255, p. 62), en se référant au réalisme pirandellien.

${ }^{9}$ S. Trancón, op. cit., p. 557.

${ }^{10}$ E. Vasques, «A Crise Realista : A Desmaterialização do Teatroe a Responsabilização do Espectador Um Século À Procura da Abstracção, da Imaterialidad e do Espectador Responsável », 2008, p. 8-9, https://www.scribd.com/document/276077871/ VASQUES-Eugenia-A-Crise-Realista.

Le réalisme au $\mathrm{XX}^{\mathrm{e}}$ siècle " subit une transformation radicale. Le concept de la réalité s'amplifie et se diversifie, en conduisant à différentes solutions formelles [...], sinon à des conceptions entièrement non figuratives », lit-on dans l'article « Réalisme » de l'encyclopédie Treccani. A propsos des notions de mimèsis, illusion, Comme Si etc. cf. Vaihinger (1911), Auerbach (1946), Hamburger (1957), Mitterand (1994), Lévesque (1997), Narboux (2000), Gefen (2002), Mitosek $(1997,2002)$, Rosset $(1984,2000)$ etc.

${ }^{11}$ J.-P. Sarrazac, op. cit., p. 59-62. 
terme de détour et celui de réalisme de détour ${ }^{12}$. On en arrive ainsi bien plus près des ce que l'on voit régulièrement dans les textes dramatiques contemporains, dont nous aimerions analyser deux exemples, afin de montrer une certaine valeur psychologique et sociale des œuvres qui abordent la réalité de manière fortement détournée et qui, de ce fait, incitent à réfléchir sur la question du réalisme et de son efficacité esthétique.

\section{LE GRAND CHARIOT}

Les deux textes ${ }^{13}$ que nous soumettons ici à l'examen se donnent, à première vue, comme éminemment réalistes (et ils le sont au fond), mais ces deux fictions dramatiques s'éloignent légèrement, chacune à sa manière, du cadre strictement mimétique. Les deux auteurs ont choisi une grande surface, un supermarché, qui est l'emblème évident du réel d'aujourd'hui, comme toile de fond de leurs intrigues respectives. Mais la réalité de 1993, l'année de la publication de Le Grand Chariot de Jacky Viallon et celle de 2013 où Bonzy, la vie, mort ou vif d'Alain Cofino Gomez a été publié, n'est plus la même. D’autant plus que le réalisme au théâtre « ne se limite pas à la production d'apparences et à la copie du réel. Il ne s'agit pas pour lui de faire coïncider la réalité et sa représentation, mais de donner de la fable et de la scène une image qui permette au spectateur, grâce à son activité

${ }^{12}$ Ibid., p. 59.

${ }^{13}$ Il existe aussi un troisième texte intéressant qui s'inscrit dans cette lignée : L'annonce faite à Benoît de Jean Louvet. La pièce, parue chez Lansman, date de 1996 (reprise ensuite en 2006 et, chez Archives \& Musée en 2017) ; elle met en scène la rencontre de deux hommes dans un grand magasin lors de laquelle Arthur se fait offrir de l'argent par Benoît, en lui racontant une histoire tragique. Les deux hommes se revoient plus tard dans un snack-bar et reviennent sur leur entrevue du passé dont on apprend qu'elle n'avait été qu'une comédie habillement jouée par Arthur, naïvement crue par Benoît (ou avalée avec plaisir comme un bon récit de fiction). Le dialogue débouche ainsi sur une certaine discussion sur les problèmes de la faintise / fiction / fictionnalité, ainsi que sur ceux de la réception émotive de celles-ci par le public. Pourtant, la rencontre des deux hommes aurait pu très bien avoir lieu dans d'autres circonstances que celle d'un hypermarché et d'un snack : le décor marchand n'y est donc pas un espace profondément signifiant. Il n'est du reste signalé que par un caddie-accessoire et quelques objets indéfinis mentionnés dans la didascalie de la Deuxième partie du drame ; il s'agit du reste d'un espace purement conventionnel, puisque les deux personnages l'évoquent seulement sporadiquement ou le construisent eux-mêmes sur scène ("Benoît traîne [...] un caddie [...] Arthur installe un décor de grand magasin », p. 224). 
symbolique et ludique, d'accéder à la compréhension des mécanismes sociaux de cette réalité $»^{14}$.

Le Grand Chariot de Jacky Viallon, dramaturge français récemment décédé ${ }^{15}$, présente une image satirique et grotesque de la société de consommation où, après avoir vécu une "grande boulimie de l'achat », les clients en perdent complètement le goût ${ }^{16}$. On observe une saturation totale du marché. La demande devient quasi inexistante. Le commerce et le secteur banquier voient la catastrophe arriver de façon inévitable, et à grande vitesse. Mais les clients sont malheureux aussi : en perdant le goût de l'achat, ils ont perdu en même temps la joie de vivre et, peut-être, le sens de la vie. La publicité, cette déesse indubitable de consommation, doit intervenir pour faire sortir le marché de l'impasse, ressusciter la demande et sauver tout le monde et... le monde entier. La solution proposée à la fin de la pièce est toute simple, banale même : il suffit de persuader les gens de la nécessité de posséder un tuyau, mais pas n'importe quel tuyau. Non sans humour, le dramaturge propose de l'appeler un «Tuyau de Contemplation $»^{17}$ ou «Un Délimitateur de Contemplation » (p. 447) par le biais duquel les clients vont acquérir le droit d'observer, d'examiner, de contempler le monde qui les entoure. En ont-ils réellement besoin? La question reste rhétorique, sans aucun doute.

L'action de la pièce de Viallon Le Grand Chariot - comme le titre peut le suggérer - se passe entièrement dans un supermarché. La didascalie initiale, mise en incipit du drame, précise : "Le plateau est nu. On entend en off une musique d'ambiance et quelques annonces publicitaires qui nous situent l'action dans un

${ }^{14}$ P. Pavis, op. cit., p. 286.

${ }^{15}$ Jacky Viallon est décédé le 10 juillet 2018 à son domicile. Auteur, comédien, metteur en scène, chroniqueur, clown, il a laissé une œuvre importante (plus de 35 textes différents), pleine d'allégresse, de finesse et d'humour. https://www.webtheatre.fr/La-mort-d-un-PoeteJacky-Viallon, consulté le 28 février 2019.

${ }^{16}$ La pièce met en scène toute une panoplie des personnages et silhouettes : 26 évoqués par l'auteur dont plusieurs collectifs (La foule du grand magasin, Les passants dans la rue, Les manipulateurs de canne à pêche, Les clients dégoûtés - huit au moins selon le découpage du texte, Les pousseurs du Grand-Acheteur, Les clients du désir, etc.). Ce procédé fait de la scène une véritable grande surface où les gens circulent dans tous les sens. De plus, tous les personnages sont banalisés en noms communs : Le directeur du magasin, La directrice de la banque, Le clochard, L'enquêtrice, L'homme pressé, etc.

${ }^{17}$ J. Viallon, Le Grand Chariot, Actes Sud [in] Collectif, Brèves d'auteurs, Babel, 1993, p. 449. Dorénavant, nous allons mettre entre parenthèses uniquement le numéro de la page de l'édition citée. 
magasin de grande surface » (p. 423). La réalité présentée nous est bien familière car elle concerne la société occidentale, celle où la consommation règne à tous les niveaux de la vie, à tous les coins de la rue. Dans la pièce, on peut l'identifier dans le leitmotif, prononcé ad libitum par les personnages de deux blocs opposés, celui des vendeurs et celui des clients : "Consommez, jetez, renouvelez, rachetez » (p. 425). Tandis que le bloc des vendeurs est unanime à ce sujet, parmi les clients, on peut observer une certaine dichotomie car ils sont divisés en ceux qui jettent et ceux qui ramassent : « Oui ! Il faut jeter ! Et moi, je suis là pour ramasser... Jeter ! Ramasser ! Voilà deux grands gestes qui mènent le monde. La moitié de la population jette pendant que l'autre moitié se baisse pour ramasser. Moi comme je n'ai jamais appris à jeter, je ramasse, c'est mon métier » (p. 427). C'est une image/vision bien triste de la société contemporaine - les uns gaspillent pour que les autres puissent se nourir - mais ne réflète-t-elle pas une certaine réalité, non seulement occidentale?

Une autre caractéristique inhérente à notre vie/réalité quotidienne est le manque de temps. On devient tellement pressé jusqu'à en devenir « oppressé » (p. 427). Un personnage de la pièce, banalisé en nom commun de L'Homme d'affaires, en est le meilleur exemple : «Vite ! Vite ! Je suis encore en retard sur mon premier retard» (p. 427). Oui, la réalité est telle que nous n'avons plus le temps pour vivre. Citons, à ce titre, le personnage de L'Homme agité : « Ah, c'est fou ce que l'on gagne comme temps à ne plus manger à midi ! C'est fou ce que l'on gagne comme temps à ne pas manger le soir ! Et le soir, j'ai décidé de ne plus dormir! C'est fou ce que l'on gagne comme temps à travailler le dimanche! On gagne beaucoup de temps à mourir jeune. Je préfère mourir jeune que de perdre mon temps à vieillir ! » (p. 428). De prime abord, ces propos peuvent paraître grotesques/burlesques ou même absurdes, mais à y réfléchir plus profondément, ils sont philosophiques et extrêmement tristes. Car cette réalité quotidienne détruit complètement la vie familiale, d'autant plus que nous sommes incités par toute sorte de techniques de manipulation à désirer toujours davantage : « Vous n'avez plus besoin d'être chez vous : tout s'épluche, se lave, se cuit tout seul ! La grande mécanique du monde s'occupe de vos affaires » (p. 425).

Durant cette course - nomen omen - quotidienne, le fait de rencontrer un individu qui « marche au ralenti » (p. 428) devient absolument aberrant. Le Passant en vacances est perçu par l'entourage comme étranger et étrange en même temps ; quelqu'un qui dépasse la norme et nuit à l'ordre établi. Dans la pièce de 
Viallon, même L'Enquêtrice ne veut pas lui parler car il lui fait « perdre de l'argent » (p. 428). L'importance de l'argent est d'ailleurs accentuée à plusieurs reprises avec son comble au milieu de la pièce quand le directeur tire à l'aide d'une corde un caddie " bourré de billets de banque, de sacs de pièces de monnaie et de chèques qui dépassent de tous les côtés » (p. 433) en constatant tout simplement que «le poids de l'argent c'est terrible sur cette terre !» (p. 433). L'ambiguïté de la signification de l'expression est évidente. Or la scène de tirer un caddie par une corde est ici la reprise d'une même scène jouée quelques répliques auparavant où deux enfants tirent péniblement un chariot bourré de marchandises. L'analogie avec le travail des enfants et l'esclavage est apparente mais ici, ces enfants deviennent esclaves de la consommation. Ils sont tristes, on les montre du doigt prace que... oui, parce qu'ils sont les seuls à ne pas avoir réussi à acheter. Quoi ? La pièce n'en parle pas car cela n'a aucune espèce d'importance : les autres l'ont et pas nous... c'est suffisant. Le parallélisme entre ces scènes est d'autant plus significatif/important qu'il concerne les deux camps adversaires : les clients et les vendeurs - les premiers sont esclaves de l'achat et les seconds, de la vente et de l'argent. Une autre association s'impose aussi : celle avec la fameuse pièce de Beckett quand Pozzo tire Lucky... Le grotesque ou le tragi-comique prend ainsi le dessus sur le réel. Le dramaturge nous propose une autre scène comique : l'image métaphorique d'une canne à pêche qui doit attraper les clients comme des poissons...

Jacky Viallon en parle ainsi : « J'essaye par l'humour de mettre en évidence la cruauté et la stupidité du « monde » dont, hélas, on fait tous plus ou moins partie. Je pense que le traitement satirique est la meilleure parade à la bêtise. Malheureusement les sujets de révolte ne manquent pas. Notre rôle en tant qu'artiste est de modestement aider à faire prendre conscience. Cette directive, un peu simpliste et naïve, nous revient souvent aux oreilles mais malgré tout on ne l'entendra jamais assez $»^{18}$.

Si l'on considère l'histoire de la civilisation, force nous est de constater qu'après une période des vaches grasses, vient celle des vaches maigres et, entre les deux, a lieu un événement exceptionnel. Dans la pièce de Viallon, on parle d'une « crise de surconsommation aiguë ! [...] Phénomène de saturation ! ( (p. 438) qui provoque une inertie des clients et leur dégoût aux achats. Le Magasinier constate qu' « il leur faudrait une bonne guerre ! » (p. 438)... pour qu'ils recommencent à

${ }^{18}$ http://jackyviallon.fr/-BIOGRAPHIE-, consulté le 14 février 2019. 
acheter. N'y aurait-il pas d'autres moyens que la destruction totale ? La sociotechnique actuelle analyse en détails le comportement des consommateurs. On ne peut plus rien cacher : la mimique, les gestes, les mouvements du corps, tout nous trahit et les spécialistes en profitent. «On n’a pas à choisir son monde. On doit regarder celui qui est imposé par la publicité » (p. 447) constate Le Publiciste. Et les clients réagissent comme programmés :

Client A : Des fois j'ai l'impression que ce n'est pas moi qui achète. Comme s'il y avait quelqu'un d'autre qui commande.

Un Autre Client : Oui cette idée me traverse souvent la main! On n'en a nullement besoin et hop c'est déjà dans le caddie ! (p. 445).

Est-ce une pièce mimétique ou plutôt satirique et allégorique ? La réponse se cache au fond de chacun de nous. Mais aussi au quotidien, dans les grandes surfaces, quand nous faisons les courses de tous les jours et achetons un tas de produits dont nous n'avons pas besoin... Le consommateur contemporain est gâté depuis des années mais son attitude devient quelque peu paradoxale : d'un côté, il a tout et il est difficile de le satisfaire, et d'un autre, il se laisse manipuler par des techniques publicitaires et achète des objets inutiles dont il n'a pas du tout besoin mais qui le rendent heureux. Cependant le bonheur ainsi gagné devient éphémère car aussi artificiel que la nécessité d'acheter. Ainsi le réel et l'artificiel s'entremêlent et il est difficile de les séparer nettement.

\section{BONZY, LA VIE, MORT OU VIF}

Avec la seconde pièce que nous aimerions examiner - Bonzy, la vie, mort ou vif ${ }^{19}$ un certain nombre d'éléments change. D’abord, la pièce appartient au répertoire du théâtre destiné au jeune public, tout en restant absolument sérieuse et fort habilement tournée ; ensuite, le supermarché n'est pas ici un lieu central, mais seulement un des lieux représentés dans la pièce (l'un des trois espaces les plus importants, en tout cas) ; et enfin Bonzy... mobilise un dispositif scénographique plus riche que celui de Le Grand Chariot. Le texte émane en général d'une vision

${ }^{19}$ A. Cofino Gomez, Bonzy, la vie, mort ou vif, Éditions P.A.T., 2013. Pour les citations qui suivront, nous allons mettre entre parenthèses uniquement la pagination. 
artistique un peu différente où le réel et le cauchemardesque ${ }^{20} s^{\prime}$ interpénètrent de manière aussi évidente que subtile, si bien qu'on a parfois du mal à percevoir la confusion ou les différences... On y est sans doute assez loin d'un récit à la Balzac.

En effet, la situation, malgré les apparences les plus réalistes qui soient, n'a rien de clair :

1 : Un personnage nommé Elle se tient devant le rideau et monologue à propos de différents problèmes psychologiques (auto-conscience, vieillissement, étrangeté des forces vitales, le temps, le désir de vivre etc.) : «C'est hier, demain, aujourd'hui peut-être. Je ne sais pas [...] », dit-Elle, en ébranlant la déixis temporelle "normale".

2 : En parallèle, Johanna et Monsieur Bing, retranchés dans un hipermarché, cherchent à résister aux ombres et aux corps réels des « rôdeurs » qui envahissent l'espace dans une vague ambiance postapocalyptique ou au moins dans une situation politico-sociale extrême. Johanna parle du reste ouvertement d'une catastrophe qui a eu lieu, tandis que Monsieur Bing, mi-enfant mi-homme, ne se sépare pas de son fusil...

3 : Dans le même supermarché, on voit encore un certain Guillaume, un chef de service probablement, qui est tantôt interlocuteur de Johanna, tantôt de Monsieur Bing, et qui « disparaît » mystérieusement, tel un spectre, dès que se produit une rencontre des jeunes adultes...

4 : En parallèle encore, un couple de scientifiques et parents de Monsieur Bing, Eliette Renard et Jean-Patrick Fox (Renard et Fox - le jeu des noms n'est pas fortuit), apparaissent, toutes les trois scènes, sur le plateau d'une chaîne télévisée où ils co-animent avec Maltus Storm un bloc d'émissions matinales sur des sujets divers et variés. Ce qui est assez déconcertant dans ce contexte, c'est qu'ils sont experts à la fois de la « métamorphologie », des « parasites zombifiants » et de la blanquette de veau...

5 : Tous ces prsonnages se retrouvent au complet dans la dernière scène (XVI) où l'on assiste à une rupture quasi initiatique : en effet, Monsieur Bing quitte sa famille en compagnie de Johanna, alors que les deux couples (Renard

${ }^{20}$ Monsieur Bing fait régulièrement le même cauchemar dont il refuse de parler (p. 24) ; Johanna avoue que sa vie est un cauchemar (p. 25) ; Elle, idem, se demande si la vie n'est pas une projection cauchemardesque de l'immagination humaine (14) ; enfin, certaines scènes du drame ne paraissent explicables que si on les considère comme cauchemars des personnages (surtout la scène XV). 
+ Fox, et Elle + Storm) s'adonnent à une danse d'oubli libératrice ou seulement illusoirement libératrice.

Mais il faut revenir un moment au commencement, c'est-à-dire à la didascalie liminaire qui, au lieu d'une description sommaire des conditions du jeu, contient une observation d'ordre psychologique : " Les portes de l'adolescence peuvent ressembler à celles d'un enfer et donner sur un monde dévasté, envahi par des morts vivants $»^{21}$. Non seulement le titre de la pièce (la vie, mort ou vif) devient ainsi plus clair, mais aussi la présence constante des êtres zombifiés, des ombres humaines et des inquiétudes protéiformes qui hantent l'univers de Bonzy. Notons qu'au niveau du message, il s'agit là d'une observation foncièrement pessimiste qui donne le "la" (fort mineur) et qui confère à l'aventure représentée une tonnalité résolument grise, malgré les accents positifs de la bonne entente entre Jo et Mister Bing, les jeunes sur lesquels se focalise la pièce. Ce pessimisme, un peu cynique par endroits, avec lequel Gomez construit son histoire, est sensible à différents moments et il nous plonge dans un climat d'une affectivité atrophique dépourvue de tout arrière-fond philosophique et spirituel qui puisse servir d'appui. Voici, pêle-mêle, quelques notations émanant de cette vision désabusée, réductionniste, un peu égoïste, mais qui reflète aussi très bien l'état précaire de l'individu dans les sociétés actuelles :

Elle : Nous, le nombre, nous sommes révulsés et transis. Nous regardons les uns les autres, la peur au ventre. (p. 14)

Elle : C'est grandir qu'ils disent. [...] Notre belle guelle d'hier n'a pas passé la nuit et au matin tu as tout abandonné qui fondait ta vie jusque-là. [...] Là, c'est la crainte qui te bouffe le ventre. (p. 22)

On entend un message publicitaire qui semble calmer l'assaut des ombres derrière la porte. Puis les coups redoublent et la porte commence à s'entrebâiller laissant apparaître des mains et des bras qui cherchent à s'immiscer et à forcer le passage. (p. 41) Eliette : "Comme il est difficile d'être un parent même lorsque les enfants sont morts ou absents, c'est une tâche tout simplement ingrate » (p. 43)

Elle : Oui, les enfants ce n'est pas une bonne chose, c'est nécessaire, je ne dis pas, il faut cela pour que tout continue et fonctionne, mais bon, si on pouvait s'en passer, on se porterait sans doute mieux. (p. 44)

${ }^{21}$ Wajdi Mouawad dans la pièce Incendies fait dire à sa protagoniste que « L'enfance est un couteau planté dans la gorge / On ne le retire pas facilement »... (Mouawad 2009 : 18). 
Malthus Storm : Moi, avec la crise, je n'ai pas le temps de penser à tout ça, je dois penser à moi avant tout, avec la crise, j'ai changé ma façon de penser. (p. 44)

Monsieur Bing : Je ne sais pas si je reviendrai un jour. / Eliette Renard : Je peux comprendre ça mon bébé. (p. 44)

Elle : Moi, j'ai quitté mes parents trop tard, c'est pour ça que je suis devenu un monstre. (p. 44)

Un certain nombre de ces énoncés aparaît sur fond sonore d'une « musique de supermarché », symbole de kitsch, de platitude et de réduction ontologique qui coupe toute motivation et considération d'ordre supérieur. Une lumière stroboscopique transforme le supermarché en une scène de thriller où les deux protagonistes, représentants de la jeune génération (Jo et Bing), sont traqués par une armée de zombies.

Le réalisme de Bonzy..., un réalisme profond, psychologique plus que décoratif, semble ainsi résider non dans la technique mimodiégétique du drame, mais bien dans la saisie de ce moment crucial de la vie humaine qu'est le passage parfois traumatisant - entre l'adolescence et l'univers des adultes ; très réaliste apparaît également la dénonciation de ce processus tout aussi douloureux qu'est la maturation permanente de l'homme qui constitue le second sujet de la pièce et qui se manifeste à travers le néologisme de métamorphologie. Le personnage nommé Elle l'exprime on ne peut mieux : « Chaque seconde nous fabriquons à partir de nous-mêmes un être qui ne sera plus ce que nous fûmes. » (sc. VIII, p. 22). Ce constat, on l'avouera, est probablement l'une des rares vérités qui fassent l'unanimité parmi les habitants de la Terre. Enfin, le gouffre séparant les générations ainsi que la rupture finale qui s'annonce définitive viennent pour compléter cette image sombre et démythifiante où aucune espérence ne semble s'insinuer.

Etant donné tout cela, on est quelque peu désorienté par le fait que la pièce ait été écrite « à partir d'une résidence dans les services pour l'enfant, l'adolescent et le jeune adulte de l'Hôpital Saint-Vincent de Paul de Lille » (le cadre est donc doublement réel). En effet, la vision du monde déployée dans Bonzy..., n’apparaît pas très thérapeutique et l'on peut même se demander dans quelle mesure (statistiquement) elle reflète l'état des relations interpersonnelles et intergénérationnelles de nos sociétés ${ }^{22}$. Bref, Bonzy... pourrait être définie comme une

${ }^{22} \mathrm{Si}$ l'on admettait l'adéquation de l'univers représenté vis-à-vis des données statistiques réelles comme trait pertinent de la vision réaliste, il y aurait ici une évidente infraction 
pièce tristement réaliste, sinon franchement pessimiste, ce qui en fait, dans les deux éventualités, une sorte de pièce à thèse. Elle a peut-être un caractère vaguement cathartique dans la mesure où elle met en garde les jeunes contre ce qui risque, au pire, de les attendre de la part des adultes, mais son message semble en désaccord avec l'objectif d'intégration interhumaine et sociale que devrait se fixer chaque thérapie digne de ce nom. En tout cas, les considérations que nous sommes en train de poursuivre dans le cas de notre lecture sont déjà significatives, puisque nous venons par là d'indiquer et de récupérer le potentiel réaliste de l'œuvre lequel réside justement dans l'énonciation de certaines thèses sociales. Pendant qu'on y est, il faudrait ajouter, en guise de postulat, que l'une des conditions d'une vision réaliste du monde et de l'homme est celle de garder dans l'œuvre une certaine conformité face à la structure objective de ces deux "ingrédiens" ; une vision irreductiblement subjectiviste saurait-elle, en effet, s'élever au rand d'une aventure réaliste?

Voilà pour le fond, pour le discours. Les dernières observations concerneront les choses, et, plus précisément, le projet scénographique inscrit dans le texte. L'une des premières questions à se poser là est d'habitude celle de savoir pour quel genre de dispositif scénique " est fait » le texte donné. La réponse est facile dans le cas de Bonzy... qui s'adapte parfaitement à ce que l'on appelle en anglais unit-set, c'est-à-dire à la scène modulaire, composée de plusieurs plateformes permettant une différenciation relativement aisée des sous-espacès scéniques à l'intérieur du box englobant. Et c'est là encore une autre brèche par laquelle Bon$z y$... échappe, peut-être malgré l'intention auctoriale, à la poétique mimétique au sens fort du terme. En pratiquant un switch mode entre trois espaces différents l'avant-scène, le supermarché et le plateau de télévision - les deux derniers emblématiques par excellence de la réalité contemporaine, Gomez obtient un effet de contraction spatio-temporelle qui non seulement risque d'être perçu comme déréalisant, mais qui l'est tout bonnement.

Cet effet est du reste renforcé par d'autres procédés de mise en scène : la lumière et le son. Quand nous voyons intervenir Elle pour la première fois, le personnage apparaît «Contre-jour [et parle d'une] voix transformée par un effet

par rapport au modèle. L'un des grands ennuis du réalisme en l'art et non seulement est que la discussion autour de cette notion va tôt ou tard buter contre une autre question fondamentale: celle de savoir ce qui, dans ce monde, est réellement ou n'y est pas. 
sonore presque ridicule [...]. » (p. 5). De manière analogue, certaines scènes - surtout celles qui prennent les couleurs des mauvais songes - se déroulent dans un éclairage spécial. C'est le cas notamment de la scène XV dont voici quelques notations didascaliques :

[...] devant la porte du hangar fermée. Derrière on entend des plaintes et des coups. [...] La lumière s'éteint puis clignotte par moments, comme des incursions stroboscopiques, mais plus lentes. [...] Johanna prend le fusil [...] On ne voit plus que les bribes de la scène à la faveur de l'intermittence lumineuse. [...] On entend un message publicitaire qui semble calmer l'assaut des ombres [...]. Noir. Eclairs lumineux et bruits de coups de feu (p. 38, 40-41)

On pourrait évoquer encore d'autres procédés contribuant à la démimétisation de l'univers dans Bonzy... mais cela ne changerait rien à l'affaire : la pièce est à la fois déréalisante et réaliste. Déréalisante par la forme ${ }^{23}$, réaliste par la position qu'elle prend (où la narration qu'elle propose) dans la vaste problématique socio-psychologique de la maturation humaine et du (prétendu ?) conflit des générations.

\section{CONCLUSION}

La fiction peut-elle être réaliste ? La réponse n'est pas aisée, vu la redoutable complexité de la notion du réalisme et l'étendue insoupçonnée du champ de réflexion qu'implique l'usage de cette catégorie esthétique. De nos jours, les choses paraissent encore plus compliquées ${ }^{24}$ sur le plan artistique, dans la mesure où le spectateur contemporain a déjà tout vu ou a déjà vu de tout. Une œuvre d'art, pour attirer l'attention du public et pour paraître effectivement attrayante doit donc souvent renoncer à une bonne partie de son potentiel réaliste, au moins en

${ }^{23}$ N'oublions pas, d'un autre côté, comme le rappelle justement M. Silhouette, que « la vérité sociale est logée [aussi] dans la forme » (2015 : 153). La forme des œuvres reflète ainsi, en quelque sorte, l'état de la société.

${ }^{24} \mathrm{Si}$ l'on voulait vraiement prendre au sérieux les propositions postmodernes, on devrait rendre les armes avant même de dire quoi que ce soit sur n'importe quel sujet, puisque c'est surtout le réalisme et la rationnalité qui se trouvent éliminés du jeu par cette mouvance pseudo-philosophique, aveuglement irrespectueuse de tout et, par là même, totalement destructrice. 
ce qui concerne le côté formel (architecture, mode de représentation, moyens employés...).

Pour aborder un problème aussi réel que la maturation de l'homme, Alain Cofino Gomez pouvait-il vraiment adopter une stratégie purement réaliste ? Cela passerait-il la rampe avec succès, de nos jours ? Il est permis d'en douter. En outre, nous l'avons déjà dit, le théâtre, qu'il le veuille ou non, est un art synthétique ; il n'est efficace que grâce à un bon projet scénographique qui est toujours et fatalement une réduction, une concentration, un choix de symboles, en un mot : une épuration ${ }^{25}$. La légère musique de supermarché que l'on entend tout au long de Bonzy... et les rayons tantôt bien rangés, tantôt chamboulés ne paraissent donc qu'un prétexte, qu'une toile de fond, qu'une surface - grande surface à l'intérieur de laquelle surgit tout à coup une grande profondeur psychologique et sociologique qui concourt à un effet esthétique d'assez bon aloi. Autre chose, ce sont les thèses posées dans le texte.

Il en est de même avec la seconde pièce - Le Grand Chariot - où on observe un procédé analogue : avec une musique d'ambiance bien réelle, munis d'un chariot réel lui-aussi, accessoire obligatoire dans un supermarché, les personnages se donnent pour l'unique but de remplir leurs caddies... Les courses quotidiennes deviennent ainsi le seul motif de leur existence et, en même temps, la seule possibilité d'accéder au bonheur. Une vision grotesque et caricaturale de l'attitude réelle elle aussi - d'une société de consommation, une société postmoderne liquide $^{26}$ dans laquelle tout est flou, tout se dissout et perd la signification et les valeurs traditionnelles.

Les analyses que nous avons effectuées nous ont conduit à un certain nombre d'affirmations relatives à différents aspects de la problématique :

1 : Quand on définit le taux de réalisme d'une œuvre fictionnelle, il est nécessaire de distinguer deux aspects essentiels, normalement coprésents, et qui interfèrent : a : le mode réaliste de représentation, c'est-à-dire une certaine adéquation entre les images et les processus connus de l'expérience et ceux construits dans l'œuvre ; b : l'engagement humain, social, politique ou spirituel de l'œuvre, c'est-à-dire l'objectif idéologique qu'elle se propose d'atteindre ; en effet, chez bon

${ }^{25}$ Le procédé anti-réaliste par excellence selon le dictionnaire Robert ( $c f$. article réalisme).

${ }^{26}$ Dans le sens que Zygmunt Bauman attribue à ce terme, surtout dans son œuvre posthume Retrotopia. 
nombre d'auteurs contemporains, contraints à innover formellement, le réalisme est perceptible essentiellement sur le plan de la pensée (convictions, conceptions) et de l'impact idéologique (prise de position, persuasion, propagande etc.). Un paradoxe apparent doit ainsi être rappelé : un artiste, quand il cherche à toucher aux problèmes réels et urgents, n'est point obligé d'adopter un mode réaliste de représentation ; une œuvre d'art qui entend considérer une problématique réelle et qui vise un objectif politico-social ou autre, ne doit absolument pas créer une apparence de réalité à travers des procédés platement réalistes. On a même souvent l'impression que la profondeur des questions soulevées dans une telle œuvre et le réalisme de celle-ci sont inversement proportionnels. " C'est dans

\section{Chez bon nombre d'auteurs contemporains, contraints à innover formellement, le réalisme est perceptible essentiellement sur le plan de la pensée (convictions, conceptions) et de l'impact idéologique (prise de position, persuasion, propagande etc.).}

ce décalage entre la réalité et la fiction que s'insinue le message, la pensée artistique » écrivait, il y a déjà un quart de siècle, Louise Vigeant ${ }^{27}$. Davide Lescot, auteur de l'article réaslime dans le Lexique du drame moderne et contemporain, remarque lui aussi qu'il s'agit, pour le théâtre, de mettre au jour les rouages du réel plutôt que de le copier, et que de nombreuses torsions subies par la réalité objective conduisent vers un réalisme philosophique ${ }^{28}$.

On nous objectera : si le réalisme des œuvres tient tout simplement dans le fait qu'elles abordent des problèmes réels qui tourmentent les contemporains, et qu'elles proposent leur vision des choses, l'immense majorité de la production artistique finira par être rangée sous l'étiquette du réalisme, ce qui fera de cette

${ }^{27}$ L. Vigeant, Visages du réalisme à travers l'histoire du théâtre, « Jeu » 1997, 85, p. 60.

${ }^{28}$ Cf. J.-P. Sarrazac, op. cit. P. 176-177. 
dernière un outil d'analyse peu opératoire. Cela est bien vrai, et nous n'avons aucune intention de dissimuler cet incovénient : la notion de réalisme en art présente en fait la grande faiblesse de paraître trop floue et, de fait, analytiquement décevante.

D'autre part, le monde actuel, qui nous semble si souvent coupé de la réalité, exige peut-être plus intensément que jamais que l'on revienne avec tout le sérieux à cette catégorie si difficile à définir et de plus en plus maltraitée dans la guerre des mondes en cours. Espérons malgré tout que le théâtre, poussé de plus en plus vers son rôle de war machine politique ${ }^{29}$ (comme tous les autres médias et tous les autres discours), va pouvoir continuer à explorer la vraie réalité des hommes, des sociétés et des choses.
Un artiste, quand il cherche à toucher des problèmes réels et urgents, n'est point obligé d'adopter un mode réaliste de représentation ; une œuvre d'art qui entend considérer une problématique réelle et qui vise un objectif politico-social ou autre, ne doit absolument pas créer une apparence de réalité à travers des procédés platement réalistes.

\section{BIBLIOGRAPHIE}

\section{Textes analysés et évoqués :}

Cofino Gomez A., Bonzy, la vie, mort ou vif, Éditions P.A.T., 2013.

Viallon J., Le Grand Chariot, Actes Sud [in] Collectif, Brèves d'auteurs, Babel, 1993.

Louvet J., L'Annonce faite à Benoît, Bruxelles, Archives \& Musée de la Littérature, 2017 (1996).

Mouawad W., Incendies. Le Sang des promesses 2, Leméac/Actes Sud, 2009 (2003). 


\section{Outils théoriques :}

Auerbach E., Mimésis : La représentation de la réalité dans la littérature occidentale, traduit de l'allemand par Cornélius Heim, Paris 1984.

Badiou A., Rhapsodie pour le théâtre, Paris 2014 (1990).

Bauman Z., Retrotopia. Jak rzq̨dzi nami przeszłość, Warszawa 2018.

Carlotti E. G., L'arte performativa tra natura e culture, Accademia University Press 2014.

Gaudreault A., Du littéraire au filmique, Paris 1999.

Gefen A., La mimèsis, Paris 2002.

Hamburger K., La logique des genres littéraires, Paris 1986 (1975).

Kibédi Varga A., Le récit postrnoderne, « Littérature »1990, 77, p. 3-22.

Lévesque S., La grande illusion ou Les pépins de la réalité, « Jeu » 1997, 85, p. 53-55.

Mayer M., Du romantisme au réalisme dans le théâtre, « Revue internationale de philosophie » 2011, 1/255, p. 43-64.

Mitosek Z., Mimesis. Zjawisko i problem, Warszawa 1997.

Mitosek Z., Mimesis - między udawaniem a referencja, « Przestrzeń Teorii » 2002, nr 1.

Mitterand H., L'Illusion réaliste. De Balzac à Aragon, Paris 1994.

Narboux J.-Ph., L'Illusion, Paris, 2000.

Pavis P., Dictionnaire du théâtre, Paris 2009.

Rosset C., Le réel et son double. Essai sur l'Illusion, Paris 1984.

Rosset C., Le réel, l'imaginaire, l'illusoire, Biarritz 2000.

Rosset C., Impressions fugitives. L'ombre, le reflet, l'écho, Paris 2004.

Rosset C., Le réel. Traité de l'idiotie, Paris 2004.

Sarrazac J.-P. (dir.), Lexique du drame moderne et contemporain, Paris 2005.

Silhouette M., Le théâtre et le réel. Questions sur le réalisme, « Mimesis. Revue germanique internationale »2015, 22, p. 153-167.

Trancón S., Realidad y realismo en el teatro, « UNED. Revista » 2006, 15, p. 535-560.

Treccani (Encyclopédie), « Realismo », http://www.treccani.it/enciclopedia/realismo/

Vaihinger H., Die Philosophie des Als Ob. System der theoretischen, praktischen und reli-

giösen Fiktionen der Menschheit auf Grund eines idealistischen Positivismus; mit einem Anhang über Kant und Nietzsche, Berlin 1911.

Vaïs M., Questions sur le réalisme, « Jeu » 1997, 85, p. 41-52.

Vasques E., «A Crise Realista : A Desmaterialização do Teatroe a Responsabilização do

Espectador Um Século À Procura da Abstracção, da Imaterialidad e do Espectador Responsável », 2008, https://www.scribd.com/document/276077871/VASQUESEugenia-A-Crise-Realista.

Vigeant L., Visages du réalisme à travers l'histoire du théâtre, « Jeu » 1997, 85, p. 56-64.

\section{Notices biographiques}

Witold Wołowski, professeur à L'Institut de Philologie Romane (KUL). Chercheur au sein de la Chaire des Littératures et Cultures Romanes, il s'intéresse surtout à la théorie du texte dramatique et du spectacle théâtral, ainsi qu'à l'histoire du théâtre francophone 
moderne et contemporain. Il est auteur des livres sur François Billetdoux (L'adialogisme et la poétisation du texte dramatique, 2005), sur les interférences génériques théâtre-récit (Du texte dramatique au texte narratif. Procédés interférentiels et formes hybrides dans le théâtre français du XX $X^{\mathrm{e}}$ siècle, 2007) et sur la didascalie (Didascalie et dadascalisation. Au théâtre et non seulement, 2016 - ouvrage réalisé grâce au soutien du Centre National de Recherche en Pologne). En 2016, il a lancé un vaste projet internationnal d'exploration de l'écriture théâtrale qui a déjà donné lieu à 3 ouvrages collectifs publiés chez Peter Lang et aux éditions universitaires de la KUL (Le Théâtre à [re]découvrir. Intermédia / Intercultures I et II, 2018 ; Teatr warty przypomnienia, 2018).

e-mail: wwolowski@interia.pl

Renata Jakubczuk est docteur habilitée ès lettres, maître de conférences à l'Université Maria Curie-Skłodowska à Lublin (Institut de Philologie Romane). Auteure d'articles sur la littérature française et francophone du XXe siècle (Camus, Sartre, Giraudoux, Anouilh, Salacrou, Dubé, Barbeau, Gélinas, Tremblay, Micone, Danis, Mouawad etc.) et de deux livres en littérature comparée : Entre la protestation tragique et la révolte dramatique : Camus et Rostworowski (2009), Téo Spychalski : Dépassement scénique du littéraire (Peter Lang 2015). Elle a rédigé aussi trois ouvrages collectifs : Parler des émotions : entre langue et littérature (2011), Recyclage et décalage. Esthétique de la reprise dans les littératures française et francophone (2013), Ami(e)s et amitié(s) dans les littératures en langues romanes (2017). Son intérêt scientifique se concentre sur la virtualité scénique du texte dramatique.

e-mail: renata.jakubczuk@umcs.pl 
KULTURA - MEDIA - TEOLOGIA

ISSN 2081-89-71

2019 nr 39, s. 97-120

\title{
Agnieszka Włoczewska
}

Kolegium Literaturoznawstwa (Uniwersytet w Białymstoku)

\section{W hołdzie paryskiej Notre-Dame. Katedra Najświętszej Marii Panny jako obraz w literaturze i jako tekst niewerbalny}

\author{
Paying tribute to Notre-Dame de Paris. The cathedral's \\ portraits in literature. Our Lady as a non-verbal text
}

\begin{abstract}
ABSTRAKT
Artykuł powstał w hołdzie dla katedry Notre-Dame de Paris, po pożarze 15 kwietnia 2019 roku. Przedstawia jej obraz w beletrystyce, od średniowiecza

(François Villon), przez renesans (François Rabelais), XIX wiek (Hugo,

Banville, Gautier, Nerval), awangardę ubiegłego stulecia (Apollinaire, Przyboś), po czasy obecne (Zerdoumi). Katedra nie tylko inspirowała pisarzy, stanowi również przykład tekstu niewerbalnego. Jej reliefy, portale i witraże ukazują historię Zbawienia i dzieje Francji, nawiązują do ludowych podań i legend oraz do dzieł literackich.

SŁOWA KLUCZOWE:

Najświętsza Maria Panna, Notre-Dame w Paryżu, katedra, Paryż, pożar,

Hugo, ekfraza, poezja
\end{abstract}

\begin{abstract}
This article pays tribute to Our Lady in Paris, and was written after the fire. It presents the various portraits of the cathedral in literature starting with the Middle-Ages and François Villon, then François Rabelais, the $19^{\text {th }}$ century writers such as Hugo, Banville, Gautier, Nerval, till present times with Apollinaire, Przyboś, and Zerdoumi. Not only has the cathedral inspired the writers, NotreDame is also a non-verbal text, or a carrier of narrating images. Its reliefs, portals and rose windows recount the history of Redemption and the history of France, many of them refer to the folk imagination or illustrate literary works.
\end{abstract}

\section{KEYWORDS:}

Our Lady, Notre-Dame de Paris, cathedral, Paris, fire, Hugo, ekphrasis, poetry

$\mathrm{D}$

wa wydarzenia spięły bolesną klamrą Wielki Tydzień i Wielkanoc 2019 roku, przypominając o przemijaniu i kruchości ludzkiego życia. W Wielki Poniedziałek spektakularny pożar strawił część kościoła Najświętszej Marii Panny w Paryżu, runęła zwieńczona krzyżem i relikwiami strzelista iglica 
Viollet-le-Duca ${ }^{1}$. W Niedzielę Zmartwychwstania 253 osoby zginęły w zamachach terrorystycznych na Sri Lance. Niewinna śmierć w symbolicznym dla chrześcijan dniu jest misterium, którego nie sposób zwerbalizować, pozostają tu jedynie kontemplacja cierpienia i potęga modlitewnej zadumy. W stolicy Francji nieszczęście miało wymiar materialny, i choć straty są ogromne, to słowa przychodzą tu łatwiej, wręcz cisną się na usta. Płonąca katedra poruszyła wiele osób; jeszcze gdy strażacy walczyli z żywiołem, ruszyła lawina różnego rodzaju komentarzy. Wypowiadali się specjaliści z wielu dziedzin. Jedni próbowali dociec przyczyn technicznych nieszczęścia. Inni zwracali uwagę na metafizyczny i symboliczny wyraz katastrofy. Wśród tylu głosów nie może zabraknąć i romanisty - literaturoznawcy. W obszarze zainteresowań dyscypliny humanistycznej, którą się on zajmuje, jest wszakże historia literatury, do której zadań należy między innymi badanie przebiegu procesu historycznoliterackiego i jego elementów, jak również odkrywanie związków literatury z życiem danej społeczności w określonych epokach oraz problemów inspirujących literaturę². Cóż zatem lepszego może on ofiarować „Najświętszej Marii Pannie płonącej”, jak ją określił Wim Wenders dzień po poża$\mathrm{rze}^{3}$, niż wspomnienie literackie? Nie rości ono sobie pretensji do przedstawienia oryginalnej, wyczerpującej i odkrywczej analizy, lecz jest skromną syntezą zainspirowaną ważnym dla społeczności europejskiej wydarzeniem. Przypomina inspirującą rolę, jaką świątynia odegrała w historii literatury. Z punktu widzenia tejże historii interesujące wydaje się, że ów jeden bezcenny zabytek został opisany na wiele różnych sposobów, a różnorodność tych obrazów odzwierciedla przemiany mentalne, ideologiczne, historyczne zachodzące w społeczeństwie francuskim na przestrzeni wieków. Artykuł nawiązuje do średniowiecznego Wielkiego

1 93-metrowa iglica, która runęła 15 kwietnia, pochodziła z lat 60. XIX wieku. Zaprojektował ją Viollet-le-Duc, a wykonał Bellu. Stanęła ona w miejscu XIII-wiecznej poprzedniczki rozebranej w 1792 roku. Czubek iglicy wieńczyły krzyż i figura koguta pełniącego funkcje piorunochronu, w której znajdowały się relikwie świętej Genowefy patronki Paryża, świętego Dionizego oraz jeden z 70 kolców z Korony Cierniowej Jezusa. Umieścił je tam arcybiskup Paryża kardynał Verdier, 25 października 1935 roku; por: https://www.notredamedeparis.fr/ la-cathedrale/architecture/la-fleche/ (28.10.2019).

${ }^{2}$ M. Głowiński, A. Okopień-Sławińska, J. Sławiński, Zarys teorii literatury, Warszawa 1972, s. 11-13; Encyklopedia Powszechna PWN, wyd. 3, t. 2, s. 210.

${ }^{3}$ Por. wywiad z reżyserem Wimem Wendersem na FranceCulture nazajutrz po tragedii; por. https://www.franceculture.fr/emissions/la-grande-table-1ere-partie/le-cinema-paradisio-de-wim-wenders (28.10.2019). 
Testamentu Villona, XVI-wiecznego Gargantui Rabelais'ego, romantycznej powieści Hugo, wierszy Gautiera, Banville’a, Nervala, modernistów Apollinaire’a i Przybosia, po liryk Kamala Zerdoumiego z kwietnia 2019 roku. Tym samym zestawia odmienne wizerunki katedry, od pełnego pokory u Villona, przez prześmiewczy z epoki renesansu, realistyczno-dokumentalny, romantyczny i pesymistyczny z XIX wieku, metafizyczno-egzystencjalny z okresu awangardy, symboliczny z naszego czasu. Przypomina także o istotnych związkach i przenikaniu się różnych gałęzi sztuki w przestrzeni katedry.

Na wstępie trzeba zasygnalizować kilka problemów. Po pierwsze, katedra jest tu zjawiskiem estetycznym, arcydziełem architektury, co w żaden sposób nie umniejsza szacunku należnego sacrum. Po drugie, niniejszy artykuł ma charakter

\section{Z punktu widzenia tejże historii [literatury] interesujące wydaje się, że ów jeden bezcenny zabytek został opisany na wiele różnych sposobów, a różnorodność tych obrazów odzwierciedla przemiany mentalne, ideologiczne, historyczne zachodzące w społeczeństwie francuskim na przestrzeni wieków.}

dwubiegunowy, bowiem przedstawia świątynię zarówno jako obraz w literaturze, jak i niewerbalny tekst. Cytowane w pierwszej części opisy Notre-Dame stanowią przykład ekfrazy, czyli figury stylistycznej o charakterze intersemiotycznym, polegającej na beletrystycznym opisie niewyrażonego słowami dzieła sztuki ${ }^{4}$. W dalszej części tekst przypomina, że najważniejszy kościół paryski był, i wciąż

${ }^{4}$ Ekfrazę jako figurę stylistyczną znano już starożytności. Pierwszym jej przykładem jest mit o dziele malarza Zeuksisa z Heraklei, który przedstawił kiść winogron tak realistycznie, że ptaki przylatywały, by skubać owoce. Szerzej znany jest przykład z Iliady Homera - opis tarczy Achillesa. 
pozostaje, swego rodzaju księgą ${ }^{5}$. Zdobiące go rzeźby, reliefy i witraże ilustrujące historię Zbawienia i historię Francji nawiązują do Pisma Świętego, apokryfów, mitów, legend ludowych, literatury. Służą wiernym kontemplującym prawdy wiary, a przy tym zachwycają finezją i wysublimowaniem.

Niech krótki rys historyczny stanowi preludium. Notre-Dame znajduje się na wyspie Cité (fr. Ile de la Cité), na rzece Sekwanie. Jest to najstarsza część Paryża zwanego niegdyś Lutecją (fr. Lutèce). Ewangelizacja tego obszaru rozpoczęła się w III wieku, a w czwartym stuleciu, prawdopodobnie na ruinach pogańskiej świątyni, wzniesiono kościół świętego Szczepana, który, kilkukrotnie przebudowywany, przetrwał do XII wieku. Wówczas biskup Paryża, Maurice de Sully, zapragnął zastąpić nadwątloną przez czas i wojny budowlę nową, i przedstawił królowi
Artykuł nawiązuje do średniowiecznego
Wielkiego Testamentu Villona, XVI-wiecznego
Gargantui Rabelais'ego, romantycznej powieści
Hugo, wierszy Gautiera, Banville'a, Nervala,
modernistów Apollinaire'a i Przybosia, po liryk
Kamala Zerdoumiego z kwietnia 2019 roku.

Ludwikowi VII jej projekt. W 1163 roku, w obecności papieża Aleksandra III, położono kamień węgielny. Wśród badaczy nie ma zgodności co do daty ukończenia

${ }^{5} \mathrm{~W}$ pierwotnej wersji artykułu ikonografia świątyni została określona terminem Biblia pauperum rozumianym w bardzo potocznym znaczeniu. Jak jednak wynika $\mathrm{z}$ badań specjalistów, wśród nich ks. profesora Knapińskiego, tzw. Biblia ubogich jest zupełnie innym zjawiskiem, a stosowanie tego terminu do średniowiecznej sztuki zdobniczej w ogóle jest mylne. Autorka dziękuje Redaktorom KMT za wskazanie tej nieścisłości i podaje za nimi źródło informacji na ten temat: Ryszard Knapiński, Biblia pauperum - rzecz o dialogu słowa i obrazu; w: Nauka, 4/2004, s. 133-164; tekst dostępny on-line http://www.pan.poznan.pl/nauki/N_404_09_Knapinski.pdf (data konsultacji: 15.10.2019). Jednocześnie warto zasygnalizować, że Wikipedia polska podaje potoczną i nieścisłą definicję Biblii pauperum, podczas gdy wersja francuska podaje rozbudowany i uszczegółowiony opis zjawiska odpowiadający faktom przedstawianym m.in. w tekstach ks. prof. Knapińskiego. 
dzieła, gdyż różnego rodzaju rozbudowy, rekonstrukcje i renowacje prowadzono praktycznie do czasów współczesnych. Najczęściej przyjmuje się, że wzniesienie dwóch charakterystycznych wież w latach 1235-1250 oraz wstawianie rozet, które zakończyło się w 1270, zwieńczyło główne prace ${ }^{6}$.

Kościół od początku miał być poświęcony Matce Boskiej. Nazwa Notre-Dame oznacza dosłownie Nasza Pani i odnosi się do Marii, Matki Jezusa. Przyjęło się tłumaczyć ją na język polski jako Najświętsza Maria Panna. Na obszarze francuskojęzycznym, czyli we Francji oraz w krajach frankofońskich, często spotyka się średniowieczne kościoły pod wezwaniem Notre-Dame. Jak zaznaczają autorzy Dziejów kultury francuskiej, wynika to ze szczególnego kultu maryjnego rozwijającego się na przełomie XII i XIII wieku, podsycanego przez cystersów i premonstratensów. Lud widział w Matce Boga opiekunkę strzegącą od zła tego świata, wierzył w cuda za Jej wstawiennictwem, wdzięczny - pielgrzymował do sanktuariów w Chartres, Coutances, Soissons, Rocamadour. Powstało wówczas wiele modlitw do Marii, wśród nich modlitwa świętego Bernarda, oraz skomponowano liczne hymny maryjne, jak na przykład Salve Regina Mater misericordiae. Tworzono również opowiadania o Jej nadprzyrodzonej interwencji. Wśród poetów czczących Matkę Boską sławę zdobył Gautier de Coinci , prawdopodobnie autor pierwowzoru Mirakla o świętym Teofilu, dramatu przerobionego przez innego znanego poetę Rutebeufa, o którym mowa dalej.

Notre-Dame uznawana jest za jeden z przykładów wczesnogotyckiej katedry, łącząc w sobie elementy mijającego nurtu romańskiego z rodzącym się gotykiem. Wprawdzie zachodnia ściana o niemalże kwadratowym obrysie $41 \mathrm{~m}$ szerokości na 43 m wysokości tkwi korzeniami w tradycji estetycznej przeszłych stuleci, ale świątynia wznosi się już na planie krzyża łacińskiego. Ma dwie wieże dzwonnicze sięgające $63 \mathrm{~m}$, ale są one jeszcze prostokątne, mało strzeliste. Nowa jest niewątpliwie fasada skierowana na zachód, z trzema portalami i rozetą o średnicy 9,6 m nad środkowym wejściem oraz dwa pozostałe witraże tego typu, północny i południowy, znajdujące się w transepcie. Wiktor Hugo określił ją jako hybrydową:

${ }^{6}$ Rozetę południową o średnicy 13 metrów podarował król Ludwik (później określany jako Święty Ludwik). Chciał on osobiście ujrzeć zwieńczenie prac, dlatego opóźnił swój wyjazd na drugą wyprawę krzyżową w 1270 roku (z której nie wrócił); por. https://www.notredamedeparis.fr/la-cathedrale/espace-jeunesse/les-tresors-de-notre-dame/les-rosaces/ (28.10.2019).

${ }^{7}$ J. Kowalski, A. i M. Loba, J. Prokop, Dzieje kultury francuskiej, Warszawa 2005, s. 108-109. 
„Nie jest to już kościół romański, nie jest to jeszcze kościół gotycki. Budowla ta nie stanowi typu. Katedra Marii Panny w Paryżu nie odznacza się (...) poważnym, masywnym korpusem, okrągłym i szerokim sklepieniem, chłodną nagością, majestatyczną prostotą gmachów, które rodzą się z łuku półpełnego. (...) Nie sposób także umieścić naszej katedry w tej drugiej rodzinie kościołów, wysokich, lekkich, bogatych w witraże i rzeźby, ostrych w kształcie, śmiałych w postawie (...). Jest to budowla okresu przejściowego"8.

Cechą charakterystyczną świątyń gotyckich jest bogata szata zewnętrzna. W przeciwieństwie do swej poprzedniczki, katedry romańskiej, niemal pozbawionej ozdób, mury w gotyku ciasno zapełniają rzeźby, reliefy i witraże nawiązujące do Biblii, żywotów świętych, apokryfów, midraszy, podań ludowych, a nawet do ówczesnej literatury. Ikonografię układano według nowego wzorca poświęcając środkowy portal Chrystusowi po Zmartwychwstaniu, tympanony boczne zdobiono scenami z życia Marii oraz świętego szczególnie czczonego w danej diecezji. Hugo był pełen zachwytu dla urody frontowej ściany określając ją jako wielką symfonię kamienną, kolosalne dzieło człowieka i narodu: „(...) niewiele jest na pewno piękniejszych kart architektury niż ta fasada, gdzie kolejno a równocześnie trzy portale wykrojone głębokimi ostrołukowymi archiwoltami, fryz dwudziestu ośmiu nisz królewskich, cały haftowany i dziergany w kamieniu, ogromna rozeta środkowa w asyście dwu bocznych okien (...) - harmonijne części przepysznej całości, ułożone w pięć gigantycznych kondygnacji - wznoszą się przed ludzkim okiem, tak rozmaite a tak uporządkowane, w bogactwie swych niezliczonych detali, rzeźbionych, rżniętych, kutych, związanych silnie i pewnie ze spokojnym ogromem całości" .

Przejdźmy teraz do meritum, do obrazów paryskiej Notre-Dame w beletrystyce. Pierwsze znane nawiązanie literackie znajduje się w Wielkim Testamencie Franciszka Villona ${ }^{10}$, uważanym za jedno z arcydzieł późnego średniowiecza. Tekst ukończony w 1461 roku składa się z ponad dwudziestu niezależnych od siebie części napisanych ośmiozgłoskowcem. Elementem spajającym utwór w całość

${ }^{8}$ W. Hugo, Katedra Marii Panny w Paryżu, tłum. H. Szumańska-Gross, Warszawa 2005, s. $118-119$.

${ }^{9}$ Tamże, s. 113-114.

${ }^{10}$ F. Villon, Wielki Testament, tłum. T. Boy-Żeleński, Warszawa 1954; por: https:// wolnelektury.pl/katalog/lektura/wielki-testament.html\#anchor-idm139931591254224 (28.10.2019). 
jest nacechowanie autorefleksją i odniesieniami autobiograficznymi. W tym kontekście Villon odmalowuje jeden z najistotniejszych elementów katedry, dzwon zwany Jacqueline (fr. bourdon Jacqueline), wykonany w 1430 roku $^{11}$, stanowiący niejako duszę kościoła i, pośrednio, duszę narodu. W zakończeniu poematu autor życzy sobie, by z okazji jego śmierci rozbrzmiewał on dostojnie:

\author{
CLXVI \\ Item, chcę, aby mi dzwoniono \\ W dzwon znaczny, co nawiętsze grzebie; \\ Ha, komuż się nie wstrząśnie łono, \\ Gdy się w nim serce zakolebie; \\ Wiadomo, sławić go nie trzeba, \\ Nieraz ten piękny kray obronił: \\ Naieźdzcę, czy też pieron z nieba, \\ Głos iego wszytko precz przegonił. ${ }^{12}$
}

Jest to życzenie na poły buńczuczne, na poły ironiczne, dzwony odzywały się przecież jedynie w wyjątkowych momentach, w najważniejszych dla królestwa chwilach. Stąd wzięło się powiedzenie „od wielkiego dzwonu”, czyli rzadko i na wyjątkową okazję. Villon traktuje swą śmierć jako wydarzenie godne królewskiego hołdu. Tym samym wykracza daleko poza średniowieczne standardy pokory, cichości, uniżoności, a przede wszystkim anonimowości twórczej.

Należy w tym miejscu zasygnalizować fakt, że w przekładzie dzieła dokonanym przez Tadeusza Boya Żeleńskiego jesienią 1916 roku brakuje następnej zwrotki z francuskiego oryginału, to jest strofy CLXVII. Kontynuuje ona myśl poprzedniego fragmentu oddając pośrednio wielkość katedralnego dzwonu, ale

${ }^{11}$ W 1686 r. ludwisarz Le Guay wykorzystał część metalu z pierwszego katedralnego dzwonu do wykonania kolejnego, który otrzymał imię Emmanuel i wisi w katedrze do dziś.

${ }^{12}$ CLXVI.

Item, je vueil qu'on sonne à branle

Le gros Beffray, qui n'est de voire;

Combien que cueur n'est qui ne tremble,

Quand de sonner est à son erre.

Saulvé a mainte belle terre,

Le temps passé, chascun le sçait:

Fussent gens d'armes ou tonnerre,

$\mathrm{Au}$ son de luy tout mal cessoit. 
i powracając pamięcią do pierwszej chrześcijańskiej świątyni na terenie, na którym stoi Notre-Dame, czyli do kościoła pod wezwaniem świętego Szczepana:
CLXVII
Les sonneurs auront quatre miches;
Et se c'est peu, demy-douzaine,
Autant qu'en donnent les plus riches;
Mais ilz seront de sainct Estienne ${ }^{13}$.

W przekładzie filologicznym, dalekim od doskonałego pierwowzoru, brzmi ona następująco:
Dzwonnicy dostaną cztery bochny;
A jeśli to mało, pół tuzina,
Tyle co dać mogą najbogatsi;
Lecz te chleby będą od Świętego Szczepana (...).

Kolejny tekst, który również zawiera odniesienie do dzwonów Najświętszej Marii Panny, to XVI-wieczny Gargantua i Pantagruel Franciszka Rabelais'go składający się z pięciu części powstałych w latach 1532-1564. Jego ton znacząco różni się od dzieła Villona. Zgodnie z duchem epoki renesansu utwór jest apoteozą możliwości człowieka jako jednostki, autorytety władzy i religii traktuje w sposób prześmiewczy, oscylując od rubasznego nieco humoru po skatologiczne, przesycone wulgarnością i przemocą wypowiedzi. Nic dziwnego zatem, że i obraz świątyni jest szyderczy. Od rozdziału XV śledzimy Gargantuę jadącego do Paryża na imponującej afrykańskiej kobyle, która była „wielka jak sześć słoni, kopyta miała rozszczepione jak koń Juliusza Cezara, uszy tak obwisłe jak u kóz langwedockich i mały róg na zadzie"14. Chciał on zwiedzić miasto, lecz mieszkańcy postępując za nim krok w krok, zmusili go do tego, by schronił się na dzwonnicach katedry: „Paryżanie bowiem jest to naród z przyrody swojej tak głupi, gapiowaty i nicpotem, że lada kuglarz, lada kramarz wędrowny, lada muł przybrany dzwonkami, kobziarz przygrywający na placu, zgromadzi więcej ludzi niż który godny wykładacz

${ }^{13}$ F. Villon, Le Grand Testament in: CEuvres complètes de François Villon, Paris 1976, s. 21100. Por:: https://fr.wikisource.org/wiki/Le_Grand_Testament (28.10.2019).

${ }^{14}$ F. Rabelais, Gargantua i Pantagruel, cz. 1 i 2, tłum. T. Boy Żeleński, Warszawa 1988, s. 37; por.: https://wolnelektury.pl/media/book/pdf/gargantua-i-pantagruel.pdf (28.10.2019). 
Ewangelii. I tak natrętnie włóczyli się za nim [Gargantuą], iż był zmuszony schronić się dla odpoczynku na wieżę kościoła Najświętszej Panny"15. Tam oczywiście zwróciły jego uwagę dzwony i gdy już nagrał się na nich „nadobnie” i dowoli, „przyszło mu na myśl, że mogłyby się bardzo dobrze zdać jako dzwoneczki na szyję dla jego klaczy, którą miał zamiar odesłać ojcu z dobrym ładunkiem sera Brie i świeżutkich śledzi. Jakoż zabrał je do swej kwatery. Skoro to spostrzeżono, w całym mieście rozpoczęła się rewolucja, ile że tam o to nietrudno (...)”16. Przerażeni paryżanie poszukali ratunku u oratorów z Sorbony, którzy ostatecznie uprosili Gargantuę o zwrot dzwonów. „Gdy tak pierwsze dni minęły i dzwony wróciły na swoje miejsce, obywatele Paryża, wdzięczni za tyle uprzejmości, ofiarowali się utrzymywać i żywić jego klacz, jak długo mu się spodoba, co Gargantua przyjął wdzięcznym sercem"17.

Na kolejne znaczące nawiązanie do Notre-Dame trzeba było czekać blisko trzysta lat, do 1831 roku, kiedy ukazała się Katedra Marii Panny w Paryżu Wiktora Hugo ${ }^{18}$. Tuż po jej publikacji zaczął rodzić się mit katedry; jeszcze w XIX wieku stała się ona jednym z najbardziej rozpoznawalnych miejsc w Europie, przyciągając nie tylko pątników, ale i zwiedzających oraz artystów ${ }^{19}$. W wieku XX, za sprawą kina, zainteresowanie przerodziło się w swego rodzaju „katedromanię"20. Ale przede wszystkim dzieło Hugo przyczyniło się do fizycznego ocalenia budowli mocno nadwątlonej przez czas i jeszcze mocniej przez rewolucję. Bowiem po 1789 roku dokonywano tam aktów profanacji, przekształcono ją na świątynię ku czci rozumu oraz najwyższej istoty, zniszczono wiele zabytków, między innymi obalono i zdekapitowano figury władców z galerii królewskiej. Rewolucjoniści

15 Tamże, s. 38.

${ }^{16}$ Tamże.

${ }^{17}$ Tamże, s. 41.

${ }^{18}$ Po pożarze 15 kwietnia była to najczęściej cytowana książka w prasie francuskiej, a z księgarń zniknęły wszystkie dostępne egzemplarze.

${ }^{19}$ Uwiecznili ją malarze różnych okresów i nurtów, wśród nich J.M.W. Turner, Camille Corot, Frank Boggs, Maximilien Luce, Vincent Van Gogh, Edward Hopper, Robert Delaunay, Henri Matisse; por. http://www.bbc.com/culture/story/20190417-stunning-and-surprisingdepictions-of-notre-dame (28.10.2019).

${ }^{20}$ Cztery spośród kilkunastu obrazów kinowych z udziałem paryskiej katedry, to superprodukcje. Chodzi o Dzwonnika z Notre-Dame Disneya z 1996 roku, Armageddon Michaela Baya (1998), Amelię Jean-Pierre Jeuneta (2001), o północy w Paryżu Woody’ego Allena (2011). 
mylnie wzięli ich za królów Francji, a de facto na ścianie zachodniej przedstawiono 28 posągów królów Judy i Izraela poprzedzających Chrystusa. Mimo dewastacji kościół przetrwał, ludzie zaś nie odeszli od wiary i po burzliwym okresie przełomu XVIII i XIX wieku podjęto wysiłki, by odrestaurować dziedzictwo narodowe. Inicjatorem akcji był Hugo, rozkochany w średniowiecznej kulturze kraju, zatroskany o stan katedry i poruszony jej losami. Uczynił zeń bohaterkę symbolizującą naród i personifikującą tożsamość Francuzów. W księdze III z tomu I znajduje się szczegółowy, niemal dokumentalny opis konsekrowanego zabytku, któremu czas wyrządził stosunkowo najmniejsze szkody, najwięcej zaś ludzie: „Lecz mimo że katedra starzejąc się pozostała piękna, trudno nie westchnąć, trudno się nie oburzyć na widok niezliczonych uszkodzeń i niezliczonych ran, które czas i człowiek zadawali tej czcigodnej budowli lekce sobie ważąc wspomnienie Karola Wielkiego (...). Na obliczu tej sędziwej królowej naszych katedr obok zmarszczki znajdziesz zawsze bliznę. Tempus edax, homo edacior ${ }^{21}$, które to słowa chętnie bym tak oto przetłumaczył: Czas jest ślepy, a człowiek głupi. Gdybyśmy mogli razem z czytelnikiem uważnie obejrzeć po kolei przeróżne ślady zniszczenia, wyciśnięte na starym kościele, zobaczylibyśmy, o ile mniejszy jest w nich udział czasu, o ile większy i dotkliwszy udział ludzi, nade wszystko zaś ludzi sztuki"22.

Ów opis trudno uznać za stricte dokumentalny. Pojawiają się w nim pewne nieścisłości, jak choćby fakt, że to nie Karol Wielki, lecz papież Aleksander w obecności króla Ludwika VII położył kamień węgielny pod fundamenty. Przed głównym wejściem nie istniało także jedenaście stopni, o których pisarz wspomina dalej. Bowiem to nie dokładność historyczna była pierwszym celem Hugo. Pragnął przede wszystkim zwrócić uwagę zwykłych ludzi i rządzących na konieczność ratowania kościoła. Stąd wykreował niezwykłe przygody w oparciu o romantyczną zasadę kontrastu. Stworzył plejadę jednoznacznych i wyrazistych charakterów, zestawiając cnoty i przywary ludzkie. Tragiczne losy pięknej i niewinnej Esmeraldy oraz ułomnego i pogardzanego Quasimodo, małostkowość i tchórzliwość Piotra Gringoire’a, zło ucieleśnione w postaci Claude’a Frollo, hipokryzja Phoebusa, złożyły się na wartką akcję, która porwała czytelników. Jednocześnie spełniło się zamierzenie Hugo - ocalała od ruiny główna bohaterka, katedra.

${ }^{21}$ Czas zżera, lecz człowiek zżera jeszcze bardziej.

${ }^{22}$ W. Hugo, Katedra Marii Panny w Paryżu, dz. cyt., s. 113. 
Wśród kolejnych XIX-wiecznych nawiązań literackich jest wiersz Gérarda de Nervala (1808-1855) z 1834 pod tytułem Notre-Dame de Paris ${ }^{23}$, który wszedł do tomu Odelettes z 1853 roku. Język poety nasycony jest obrazem śmierci i zniszczenia. Katedra, choć stara, sama stanie się grabarką miasta, które ją zrodziło. Jej agonia będzie powolna, „Czas szarpnie nią jak wilk wołem, skręci jej żelazne sploty i zębem nadgryzie stare kamienne kości", a świadkami obracania się świątyni w ruinę będą ludzie z całego świata. Zdaniem poety Notre-Dame stanie się wrakiem, jej wielkość, moc i dostojeństwo należą do przeszłości, pozostanie jedynie wspomnienie po nich uwiecznione przez Hugo na kartach powieści. Niektórzy z dzisiejszych komentatorów, chętnie podkreślających upadek religii i wartości na Zachodzie, ujrzeliby w tym krótkim wierszu Nervala proroczą wizję przyszłości. Wypada jednak zaznaczyć, że ten pesymistyczny liryk mógł zrodzić się pod wpływem światopoglądu pisarza, który nie skłaniał się ku apoteozie religii i wiary chrześcijańskiej. Był zwolennikiem idei republikańskich, wolnomularzem, a także cierpiał na zaburzenia nerwowe, które ostatecznie doprowadziły go do samobójczej śmierci ${ }^{24}$.

${ }^{23}$ Gérard de Nerval, Notre-Dame de Paris :

Notre-Dame est bien vieille: on la verra peut-être

Enterrer cependant Paris qu'elle a vu naître ;

Mais, dans quelque mille ans, le Temps fera broncher

Comme un loup fait un boeuf, cette carcasse lourde,

Tordra ses nerfs de fer, et puis d'une dent sourde

Rongera tristement ses vieux os de rocher!

Bien des hommes, de tous les pays de la terre

Viendront, pour contempler cette ruine austère,

Rêveurs, et relisant le livre de Victor:

- Alors ils croiront voir la vieille basilique,

Toute ainsi qu'elle était, puissante et magnifique,

Se lever devant eux comme l'ombre d'un mort!

https://www.poesie-francaise.fr/gerard-de-nerval/poeme-notre-dame-de-paris.php (28.10.2019).

${ }^{24}$ Por. biografie Nervala, np. A. Béguin, Gérard de Nerval, Paris 1945; G. de Nerval, Oeuvres complètes, Pléiade. Dodajmy tu, iż mimo samobójczej śmierci poeta został pochowany na stołecznym cmentarzu katolickim Père-Lachaise, a żałobna Msza św. odprawiona została właśnie w katedrze Notre-Dame. Kościół uznał stan psychiczny Nervala za dostateczną przesłankę, by usprawiedliwić czyn poety i nie odmówić mu prawda do katolickiego pochówku. 
Wiersz Nervala kontrastuje z kolejnymi dziełami z tamtego okresu upamiętniającymi katedrę. Dwóch znanych poetów, Banville i Gautier przedstawili romantyczny i metafizyczny obraz Najświętszej Marii Panny. W dwanaście lat po ukazaniu się powieści Hugo Notre-Dame de Paris Théodore de Banville (1823-1891) umieścił cytat z niej w wierszu Amour angélique (Anielska miłośc) ${ }^{25}$, który wszedł do jego inauguracyjnego tomiku Les Cariatides opublikowanego w 1843 roku. Jest to fragment rozmowy Esmeraldy ze świeżo poślubionym Gringoire'em: „- A miłość? - pytał dalej Gringoire. - O! Miłość...(...). To być dwojgiem, co w jedno się zlewają. To mężczyzna i kobieta stopieni w jednego anioła. To niebo!"26. Trudno o definicję bardziej klarowną i piękniejszą. Oddaje ona ducha poematu Banville'a, który, choć był parnasistą, nawiązywał w widoczny sposób do idei romantycznych, zwłaszcza do wysublimowanego niebiańskiego uczucia, do postaci aniołów, archaniołów, świetlistych i eterycznych ciał niebieskich, zapachów i kwiatów pełnych cudownych woni. Pośrednio odnosi się do katedry stanowiącej mistyczne miejsce poza czasem i przestrzenią, przepełnione duchowością, w którym w uniesieniu trwa miłość. Ta przyobleka się zarówno w postać Esmeraldy, jak i Najświętszej Marii Panny, ukochanej kobiety o niewinnym, dziecięcym uśmiechu. Poeta wierzy, że miłość, podobnie jak katedra, będą wiecznie trwać.

Powieść Hugo posłużyła za iskrę twórczą również Théophile’owi Gautierowi. Wiersz Notre-Dame z tomu La comédie de la mort (1838) ${ }^{27}$, głoszący chwałę i piękno katedry, składa się z trzech części i liczy 27 strof. W drugiej autor wyznaje, że latem codziennie o godzinie ósmej wieczorem szedł ku świątyni: „Z twą książką w kieszeni, Wiktorze, szedłem często ku wieżom Najświętszej Marii Panny...”, by podziwiać wspaniały spektakl natury - blaski zachodzącego słońca „wielkiego niczym złoty balon", grające na fasadzie i elementach architektury. Dla poety są to chwile modlitewnej kontemplacji, dające wytchnienie od banału codzienności, pustoty salonowego życia, czczych rozmów ze znajomymi.

Katedra stanowi materiał twórczy zarówno dla plastyków i literatów. Jej piękno i kolorystyka godne są najświetniejszych pędzli, stąd odwołanie w wierszu do Rubensa i Tycjana. Rozety stają się oczyma, które nie tylko widzą paryżan,

${ }^{25}$ Ze względu na długość utworu por. wersję on-line na: https://www.poetica.fr/poeme-1737/theodore-de-banville-amour-angelique/ (28.10.2019).

${ }^{26}$ W. Hugo, Katedra Marii Panny w Paryżu, dz. cyt., s. 107.

${ }^{27}$ https://www.poetica.fr/poeme-5676/theophile-gautier-notre-dame/ (28.10.2019). 
ale też roztaczają wokół mistyczny blask. W świetle zachodzącego słońca kamień przeistacza się w zwiewną materię, granit staje się tiulem, arkady koronką, posadzka ogrodem kwiatowym godnym Alcyny lub Morgany, mieniącym się odcieniami niebieskiego i czerwieni.

Katedra nie tylko stanowi obraz, jest również tekstem. Proste i pobożne dłuta wypisały na niej historie święte i legendy minionego czasu. Jednorożce, wilkołaki, karły, smoki, bazyliszki, baśniowe węże, rycerze pogromcy złych mocy, miriady świętych miały przypominać ludziom, że na tym świecie zło ściera się nieustannie z dobrym, a rozstrzygnięcie nastąpi na dniu Sądu, o którym przypomina tympanon nad głównym wejściem do kościoła.

Wreszcie katedra otwiera wspaniałą perspektywę na Paryż. Wchodząc na jej wieże, człowiek czuje dreszcz strachu, gdyż wznosi się bliżej Boga. Widok jednak koi niepokój: „Ależ jest wielki! Ależ jest piękny!” wykrzykuje podmiot liryczny w zachwycie. Naraz stają mu przed oczyma Tyr, Babilon i Rzym. Niezliczone dachy, domy, pałace, kopuły, ulice, mury w swej mnogości i różnorodności zdają się być dziełem samego Boga. Tutaj autor zdaje się odnosić do rozdziału II z części trzeciej powieści Hugo, Paryż z lotu ptaka, przedstawiającego miasto w roku 1482.

Trzecia część wiersza Gautiera to powrót do cierpkiej rzeczywistości. Paryż jest piękny i wysublimowany tylko z wysokości wież Notre-Dame. Schodząc, doświadcza się jego metamorfozy: wszystko spłaszcza się i pospolicieje. Katedra wydaje się być świętą matroną pośród stada swych kociąt.

Wiersz Gautiera podkreśla jej uniwersalizm i symbolizm jako skarbnicy pamięci narodu. Przedstawia ją jako miejsce mistyczne, które czuwa nad chrześcijańskim dziedzictwem kraju. A osobom wrażliwym daje poczucie obcowania z sacrum pozwalając wznosić się ku niebu.

Na zakończenie części literackiej przytoczmy jeszcze trzy wiersze: Dzwony Wilhelma Kostrowickiego z tomu Alkohole $(1913)^{28}$, Notre-Dame Juliana Przybosia

${ }^{28}$ Guillaume Apollinaire, Les cloches Mon beau tzigane mon amant Écoute les cloches qui sonnent Nous nous aimions éperdument Croyant n'être vus de personne

Mais nous étions bien mal cachés Toutes les cloches à la ronde 
z tomu Równanie serca $(1938)^{29}$ oraz Najświętsza Maria Panna Kamala Zerdoumiego $^{30} \mathrm{z}$ kwietnia 2019 roku.

Apollinaire, jeden z czołowych modernistów, dostrzegał i rozumiał potencjał religii i tradycji, dlatego chętnie i często nawiązywał do nich w utworach. Szczególnie bliska była mu postać Najświętszej Marii Panny, symbol szczęśliwego dzieciństwa spędzonego nad Morzem Śródziemnym. Matka zawierzyła go w Jej

Nous ont vus du haut des clochers

Et le disent à tout le monde

Demain Cyprien et Henri

Marie Ursule et Catherine

La boulangère et son mari

Et puis Gertrude ma cousine

Souriront quand je passerai

Je ne saurai plus où me mettre

Tu seras loin Je pleurerai

J'en mourrai peut-être

G. Apollinaire, Alcools suivis de Calligrammes, Paris 2013, s. 99; https://fr.wikisource. org/wiki/Les_Cloches_(Apollinaire) (26.10.2019).

${ }^{29}$ Julian Przyboś, Notre-Dame

Z miliona złożonych do modlitwy palców wzlatująca przestrzeń!

Lecz zdjęto mnie z iglicy jak z haka Wnętrze - przerażenie.

Wyszydzony i opluty wśród poczwar rozdziawionych deszczem

wiem: Co znaczę ja żywy o krok od filarów!

Te mury z odrąbanych skał - jak łby ponade mnie

zmartwychwstają z sarkofagu.

Kto wstrząsnął tą ciemnością, nagiął - i ogarnął?

Wiem. Obciążone Jezusami krzyże

trzeba wyostrzyć w piony budowniczych drabin

i swoją wolę, zrównaną z niezgłębionym lazurem,

swoją śmierć

z ostrołuku trafić -

-tam na kluczu sklepienia drga zamknięty pęd strzał -

- i trwać pod hurgotem głazów szybujących coraz wyżej i wyżej,

aż je, nie skończone, nagły zawrót

stoczy ze szczytu w dwie wieże, urwane dna.

Kto pomyślał tę przepaść i odrzucił ją w górę.

http://hamlet.edu.pl/przybos-notre-dame (26.10.2019).

${ }^{30}$ Kamal Zerdoumi (1953-) współczesny poeta francuski pochodzenia algierskiego. Pierwsze utwory poetyckie powstały w latach 90. XX wieku; sławę przyniósł mu tom L'exil et la mémoire z 2011. 
opiekę i ubierała małego Guy na biało i niebiesko, w kolory maryjne. Jako uczeń gimnazjum Wilhelm wykradał się z kolegą do kaplicy przy internacie, by modlić się do Niej w uniesieniu. Już jako dorosły przywoływał w wierszach kwiaty symbolizujące Marię.

Imię to ma dla poety również bolesne konotacje. Przypomina dwie kochanki, z którymi się rozstał - Marey z belgijskiego Stavelot oraz malarkę Marie Laurencin. Nieprzypadkowo w utworze Les cloches (Dzwony) wymienia wśród paryskich dzwonów noszących popularne imiona właśnie dzwon Maria z Notre-Dame. Ze względu na dwuznaczność skojarzeń imienia liryk odzwierciedla krańcowo różne nastroje. Wspomnienie szczęśliwej miłości kontrastuje z bólem rozstania. Dlatego w ostatecznym rozrachunku przesycony głębokim smutkiem wiersz należy odczytywać jako pesymistyczny. Podmiot liryczny czuje się niekochany i porzucony. Dzwony są świadkiem nieszczęścia zerwania i rozstania. Nie tylko ich dźwięk będzie przywoływał miłość, która przeminęła. Bijąc w południe, kołyszą się i kreślą w powietrzu linię, która przypomina uśmiech. Jednak dla poety jest to szyderczy chichot pozbawiony jakiejkolwiek empatii, potęgujący ból niekochanego i sprowadzający mu do głowy czarne myśli. W tym kontekście dzwon Maria z Notre-Dame nie przynosi ukojenia.

Wiersz Przybosia, także reprezentującego awangardę, ma wymiar nie tylko egzystencjalny, ale przede wszystkim transcendentny. Przedstawia katedrę jako metafizyczną przestrzeń zawieszoną ponad czasem i zmysłowo postrzeganym światem, w której doświadcza się spirali bytu. Wchodzący do świątyni człowiek wiruje między światami, raz jest na ziemskim padole, by za chwilę wzlecieć ku niebu, a potem znów opaść. Poeta osiąga efekt nadrzeczywistości dzięki zastosowaniu przesadni i oksymoronu, jednej z ulubionych figur modernistów. Obraz zabijanej śmierci, wzlotu i upadku, zamkniętego pędu, uwięzionych w locie strzał, odrzuconej w górę przepaści świadczą o zerwaniu z prawami natury i fizyki. „Milion złożonych do modlitwy palców” sugeruje jak stara jest świątynia, do której pielgrzymowały pokolenia wiernych. Lecz sędziwy wiek nie jest schyłkiem, a początkuje nowe perspektywy i zapowiada przyszłość. W kościele przypominającym sarkofag dominuje życie, nieustannie dokonuje się w nim zmartwychwstanie, Boska wola, moc i łaska pokonują śmierć. Sam podmiot liryczny doświadcza przejścia ze śmierci do życia - zdjęty z iglicy, jak z haka, stoi wszakże żywy pod kamieniami, które również ożywają. Innymi słowy ujmując, wzrok osoby oglądającej osuwa się z wysmukłej i subtelnej iglicy w dół, ku ohydnym gargulcom 
rzygaczy. Kontemplujący pielgrzym doznaje wstrząsu estetycznego i doświadcza niemiłego zderzenia piękna Boskiej wzniosłości i brzydoty bytu. Z kolei krzyż wydaje się poecie drabiną, po której można się wspiąć do nieba. Jest to wyprawa dość ryzykowna, bo w każdym momencie potężny pęd powietrza może ściągnąć w przepaść wież bez dna.

Przykłady literackich obrazów Notre-Dame kończy wymowny wiersz Kamala Zerdoumiego z kwietnia 2019 roku, powstały z bezpośrednio pod wpływem kontemplacji płonącej Notre-Dame:

\author{
W tym gorącym momencie \\ twa iglica uległa \\ żarłocznym płomieniom \\ Zerwała się więź \\ $\mathrm{z}$ niedosięgłym Misterium \\ Noc która tu zapada \\ podsyca twe czerwonawe rany \\ „Las” dębowy \\ twe sklepienie \\ jest już tylko wspomnieniem \\ o katedro \\ wielowiekowa córko \\ Historii \\ świadku momentów \\ chwały i cienia \\ Francji \\ cudzie transcendentny \\ dla całego świata \\ teraz męczennico \\ czerwieni ognia \\ matko boleściwa \\ niewysłowiony bólu \\ bądź pozdrowiona ${ }^{31}$.
}

Notre-Dame stała się nie tylko bohaterką dzieł z różnych dziedzin sztuki, nosi też na sobie teksty wpisane w reliefy, grupy rzeźb czy witraże, przez co stanowi przykład swoistego tekstu niewerbalnego. Szczegółowe opisy ikonografii

${ }^{31}$ https://www.poetica.fr/poeme-5684/kamal-zerdoumi-notre-dame/ (28.10.2019), tłum. A. Włoczewska. 
gotyckich katedr można znaleźć w wielu książkach poświęconych sztuce średniowiecza $^{32}$, dlatego artykuł sygnalizuje jedynie niektóre aspekty. Na paryskiej katedrze znajdujemy nawiązania do Biblii i żywotów Świętych. Trzy portale frontowe ukazują sceny Sądu Ostatecznego, Ukoronowania Matki Boskiej na Królową nieba i ziemi oraz ziemski Żywot Marii. Rozety i witraże przywołują postacie ze Starego i Nowego Testamentu. Wiele rzeźb i reliefów przedstawiających baśniowe stwory odwołuje się do francuskiej kultury ludowej. Średniowieczni artyści nawiązali nawet do żydowskich midraszy, umieszczając na chrześcijańskiej katedrze demoniczną Lilit uchodzącą za żonę szatana. Jest też mniej kontrowersyjne a interesujące nawiązanie do ówczesnej literatury - na północnym tympanonie umieszczono sceny jednego z najstarszych dramatów, Mirakla o Teofilu z 1270 roku.

\section{Notre-Dame stała się nie tylko bohaterką dzieł $z$ różnych dziedzin sztuki, nosi też na sobie teksty wpisane w reliefy, grupy rzeźb czy witraże, przez co stanowi przykład swoistego tekstu niewerbalnego.}

Po prawej stronie fasady zachodniej znajduje się najstarszy z trzech portali, znany jako portal świętej Anny. Powstał on pod koniec XII wieku dla ówczesnego kościoła świętego Szczepana, w miejscu którego stanęła Notre-Dame. Ilustruje apokryficzny tekst znany jako Ewangelia Pseudo-Mateusza, przedstawiający sceny z życia Marii i dzieciństwa Jezusa. Najniższa część tympanonu zawiera relief, na którym Maria w asyście rodziców Anny i Joachima zostaje przedstawiona Józefowi. Wyżej znajdują się sceny Zwiastowania, Narodzin Jezusa, Epifanii i Hołdu Pasterzy. Jest także Herod przyjmujący trzech królów. Górną, centralną część

\footnotetext{
${ }^{32}$ Por. np. G. Duby, Historia kultury francuskiej. Wiek X-XX, tłum. H. Szumańska-Grossowa, Warszawa 1965; Rok Tysięczny, tłum. M. Malewicz, Warszawa 1997; Czasy katedr. Sztuka i społeczeństwo 980-1420, tłum. K. Dolatowska, Warszawa 1986; R. Toman, Sztuka romańska. Architektura, rzeźba, malarstwo, tłum. R. Wolski, b.m. 2008; E. Panofsky, Studia z historii sztuki, tłum. J. Białostocki, Warszawa 1971.
} 
tympanonu, zajmuje majestatyczna postać Marii trzymającej Jezusa na kolanach, zasiadającej na budynku katedry niczym na tronie.

Środkowy portal Sądu Ostatecznego zawdzięcza swą nazwę głównemu reliefowi nawiązującemu do Ewangelii świętego Mateusza. Ukazuje on siedzącego na tronie Chrystusa z przebitymi rękoma i bokiem, opierającego stopy o niebieskie Jeruzalem. Adorują Go dwa anioły trzymające symbole Męki: krzyż, gwoździe i włócznię. Po bokach Chrystusa klęczą: święty Jan Ewangelista oraz Matka Boska, której obecność ujednolica tematycznie decorum świątyni. Poniżej znajduje się scena Sądu, $\mathrm{z}$ archaniołem Michałem trzymającym wagę i zabierającym dusze dobre i szatanem zabierającym grzeszników. Na łukach okalających scenę widzimy patriarchów i proroków, doktorów Kościoła, męczenników, panny roztropne oraz putti.

Po lewej stronie znajduje się portal Najświętszej Marii Panny, wbudowany w latach 1210-1220. Przedstawia historię zaczerpniętą z tradycji Kościoła. Najniższy pas zawiera sześć figur proroków i królów Izraela trzymających Arkę Przymierza. Nad nim ukazano scenę zaśnięcia Marii, nowej Arki, otoczonej dwoma aniołami i uczniami. Najwyższa część tympanonu przedstawia Chrystusa koronującego Matkę na Królową nieba i ziemi.

Warto zwrócić uwagę na szczególnej urody i niezwykłej wymowy płaskorzeźbę umieszczoną u dołu środkowej kolumny z portalu Marii. Jej trzon stanowi figura Matki Boskiej, a pod jej stopami średniowieczny artysta ukazał epizody nawiązujące zarówno do Księgi Rodzaju, jak i midraszy: stworzenie Ewy i przedstawienie jej Adamowi oraz wypędzenie pierwszych rodziców po upadku z Raju. Najciekawsza jest scena momentu kuszenia: widać na niej Adama i Ewę stojących pod drzewem, a na nim, zamiast węża, siedzi Lilit, demoniczna postać kobieca niezwykłej urody, jednocześnie kusicielka i jędza ${ }^{33}$. To ona, wdzięcząc się i uśmiechając, podaje Ewie owoc. Jednak od początku wydaje się być na straconej pozycji. Bezpośrednio nad nią góruje Matka Boska, która w Biblii depce wężowi łeb, tu zaś stoi czarownicy na głowie.

${ }^{33}$ Imię Lilit (lub Lilith) pojawia się w starotestamentalnej Księdze Izajasza (por. Biblia Tysiąclecia), zaś szerzej mówi o niej tradycja mitologiczno-biblijna. Midrasze wskazują, że to ona, a nie wąż, skusiła Ewę do złamania Bożego zakazu; uznaje się ją za pierwszą żonę Adama lub za żonę samego szatana. 
Innym nawiązaniem stricte literackim jest ilustracja mirakla ${ }^{34}$ o świętym Teofilu $^{35}$ znajdująca się na tympanonie nad północnym wejściem do świątyni. Autorem jednej $\mathrm{z}$ wersji utworu jest paryski poeta Rutebeuf wspierany przez króla Ludwika (Świętego). Bohater dramatu został okradziony z majątku przez biskupa, i aby odzyskać swe dobra zaprzedał duszę diabłu. Jednak po siedmiu latach poczuł wyrzuty sumienia, tymczasem diabeł nie chciał go odstąpić i dopiero interwencja Matki Boskiej wyrwała Teofila z rąk złego. Tympanon paryskiej katedry przedstawia historię $\mathrm{w}$ trzech sekwencjach: gdy pokrzywdzony paktuje z diabłem przypominającym wyglądem kozła o łapach jaszczura, gdy Teofil doświadcza dostatku dóbr ziemskich oraz gdy nękany sumieniem zwraca się do Marii Panny o pomoc, a Ta przychodzi mu na ratunek mierząc w złego bronią białą. Dzieło cechuje się zarazem surowością - jest na nim niewiele detali, i jednocześnie starannym i subtelnym wykończeniem. Szaty bohaterów oraz zwierzęce cechy diabła ukazano w plastyczny i mistrzowski sposób. Potrójny relief otoczony jest liśćmi i kwiatami lilii symbolizującymi Matkę Boską.

Dzisiejszego turystę oglądającego Notre-Dame może zdziwić mnogość dziwacznych rzeźb, jak choćby słynna strzyga kontemplująca Paryż, gargulce rzygaczy czy chimery. Jednorożne, wilkołaki, bazyliszki, węże zdają się być nader odległe od chrześcijańskiego sacrum i kłócić się z nauczaniem Kościoła i jednocześnie przydają katedrze pozór eklektyzmu. Tymczasem w średniowieczu czerpano chętnie z kultury ludowej zapożyczając z niej najbrzydsze stwory, aby spersonifikować zło. Ich odrażający wygląd miał budzić strach przed nieczystymi mocami. Oddziaływał na uczucia niepiśmiennych wyznawców pielgrzymujących do katedry skłaniając ich, by w codziennym życiu kierowali się dekalogiem i miłością bliźnich. W XIX wieku, pod wpływem romantycznej estetyki, ponownie odkryto ich istotę, a także doceniono swoiste piękno. Duży wkład miał tu wymieniony już wcześniej Wiktor Hugo; kierowała nim niewątpliwie pasja historii, ale i wrażliwość na średniowieczną sztukę. Stał się on jednym z orędowników odtworzenia rzeźb zniszczonych przez rewolucję francuską. Dlatego warto w tym kontekście przywołać jego Przedmowę do Cromwella z 1827 roku, w której podkreśla,

${ }^{34}$ Gatunek literacki, najczęściej dramat, z okresu średniowiecza, cieszący się popularnością szczególnie od IX do XIII wieku, opowiadający o grzesznych wydarzeniach z życia zwykłych ludzi, których ostatecznie ratuje od upadku Matka Boska.

${ }^{35}$ J. Kowalski, A. i M. Loba, J. Prokop, dz. cyt., s. 110-111. 
że sztuka ludowa oraz koloryt lokalny to jeden z fundamentów estetyki romantyzmu i zarazem element dziedzictwa narodowego. Wskrzeszanie legend i baśni, nawiązywanie do twórczości prowincjonalnych, najczęściej anonimowych artystów stało się jednym z najważniejszych zadań dla pisarza. W oparciu o nie Hugo rozwinął pojęcia sublimacji i groteski. Jeśli pierwsze wznosi nas ku Bogu, doskonałości i absolutowi, to drugie przypomina, że jesteśmy ułomnymi istotami ziemskimi obarczonymi bagażem niedoskonałości. I choć obie bez siebie nie mogą istnieć, nawzajem się dopełniają i uwypuklają poprzez kontrast, to - jak się wydaje - grotesce przypisywał większą wartość: „Groteska odgrywa ogromną rolę w kształtowaniu się myśli nowożytnych. Jest wszechobecna; z jednej strony tworzy zniekształcenie i brzydotę, z drugiej daje komizm i błazeństwo. (...) To znów ona ukazuje w chrześcijańskim piekle te obrzydliwe stwory, które zostaną przywołane przez cierpkie umysły Dantego i Miltona; to znów ona wprowadza śmieszne postacie"36. Wprawdzie już starożytni znali i stosowali groteskę w sztuce, jednak średniowieczni twórcy popisali się wyjątkową wyobraźnią kreując gargulca z Rouen, bazyliszka z Metz, smoka z Troyes, koto-żółwia z Tarascon ${ }^{37}$.

Niektóre rzeźby pełniły nie tylko funkcje estetyczno-edukacyjne, ale także praktyczne. Rzygacze z Notre-Dame - dekoracyjne paszcze wystające poza ściany budynku, to artystyczne zakończenie rynny. Ze względu na ogromną powierzchnię dachu katedry architekci zdecydowali się umieścić ich tak wiele, by skutecznie odprowadzały wodę deszczową odrzucając ją jak najdalej od budynku i chroniąc w ten sposób mury świątyni przed wypłukiwaniem z nich spoiwa.

To właśnie rzygacze utrzymywały we względnej suchości jeden z istotniejszych elementów kościoła - rozety. Za dnia z zewnątrz wyglądają niepozornie, natomiast wewnątrz dają niezwykłe efekty optyczne i kreują nową mistyczną przestrzeń skłaniającą do kontemplacji spraw Boskich. Z kolei po zmierzchu, gdy wewnątrz płonęły świece, rozety roztaczały na zewnątrz piękny blask przywołując znów sacrum. Nazwa rozeta wzięła się od róży - witraż miał być Rajskim kwiatem o szklanych, różnobarwnych płatkach rozchodzących się promieniście. Każdy z nich dzieli się na medaliony, w których artyści zawarli momenty z życia proroków i świętych oraz niektóre sceny biblijne, anioły, cnoty, ale także miesiące roku,

${ }^{36}$ V. Hugo, Préface de Cromwell, Paris 1949, s. 9 i 10, https://ecrivains-publics.fr/wp-content/uploads/2016/10/preface_de_cromwell_-_hugo.pdf (28.10.2019).

${ }^{37}$ Tamże. 
zodiak, grzechy i przywary ludzkie. To jednak nie one są najważniejsze w rozecie. Jej centrum odpowiadające środkowi kwiatu zajmuje medalion przedstawiający Chrystusa w chwale albo Jego Matkę. Płatki-medaliony kręcą się niejako dokoła tego, co najistotniejsze. Średniowiecznym twórcom chodziło nie tyle o estetyczne doznania wiernych, co o dydaktyzm. Rozeta miała głównie znaczenie symboliczne. Każdy medalion poświęcony jednej osobie przypomina, że człowiek jest jednostką. Tyle że działając w pojedynkę wypada blado i słabo. Pełnię blasku, a więc sił i znaczenia, nabiera dopiero w grupie, która ukierunkowana jest na ten sam cel - drogę do świętości i do Boga ${ }^{38}$. Medaliony zawierające personifikacje ludzkich wad ostrzegają wiernych przed złem, które przybiera nierzadko piękne kształty i wabi oko feerią barw, lecz oddala człowieka od Boga i ostatecznie wiedzie go na manowce. Dlatego medaliony z tymi wyobrażeniami nie sąsiadują bezpośrednio z centralnym obrazem, lecz znajdują się na zewnętrznych okręgach.

Dwie rozety w Notre-Dame, północna i zachodnia, ukazują Marię w chwale. Na pierwszej z nich ${ }^{39}$, w wewnętrznym kręgu bezpośrednio sąsiadującym z Matką Boga, umieszczono postacie proroków ze Starego Testamentu. Kręgi środkowy i zewnętrzny przedstawiają starotestamentowych sędziów i królów. Pod rozetą, w prawej pachwinie łuku ukazano scenę, na której antychryst zabija Eliasza i Enocha, zaś w lewej pachwinie - śmierć szatana.

Rozeta zachodnia ${ }^{40}$, umieszczona nad środkowym wejściem do świątyni, przedstawia Marię z Dzieciątkiem na kolanach, otoczoną bezpośrednio dwunastoma medalionami z figurami proroków. Środkowy krąg medalionów zawiera wyobrażenia znaków zodiaku oraz grzechów, wad i występków, wśród nich są złość, bałwochwalstwo, rozpacz, kłótliwość, rozpusta, duma, niewdzięczność, skąpstwo. Zewnętrzny krąg przedstawia cnoty oraz personifikacje dwunastu miesięcy roku. Z zewnątrz, czyli od strony dziedzińca, rozeta wygląda jak wielka aureola nad głową Marii. Figura stoi bowiem na tle okrągłego witraża.

${ }^{38}$ https://www.notredamedeparis.fr/la-cathedrale/espace-jeunesse/les-tresors-de-notre-dame/les-rosaces/ (28.10.2019).

${ }^{39}$ http://www.therosewindow.com/pilot/Paris-N-Dame/N-rose-Frame.htm (28.10.2019).

${ }^{40}$ http://www.therosewindow.com/pilot/Paris-N-Dame/W-rose-Frame.htm (28.10.2019). 
Południowa rozeta z Notre-Dame, ofiarowana przez króla Ludwika, przedstawia w samym środku apokaliptycznego Jezusa w chwale ${ }^{41}$. W pierwszym opasującym Go pierścieniu dwunastu promieni znajduje się tyleż samo medalionów, w których umieszczono postacie apostołów, świętych, króla, a także scenę Sądu Salomona, w której oddaje dziecko jego matce. Od dwunastu promieni rozchodzą się dwadzieścia cztery nowe, tworzące pierścień zewnętrzny, w którego medalionach znajdują się postacie świętych, panien mądrych, a także sceny z Legendy Świętego Mateusza: chrzest króla Egiptu; magów egipskich próbujących wskrzesić egipskiego królewicza oraz wskrzeszenie tegoż; świętego Mateusza ze smokami oraz stojącego przed królem Hirtacusem. Zewnętrzny krąg zawiera medaliony $\mathrm{z}$ aniołami trzymającymi świece, korony i kadzielnice. Przedstawiono też dwie sceny z Nowego Testamentu: Ucieczkę Marii i Józefa z Dzieciątkiem do Egiptu oraz Uzdrowienie paralityka. W rozecie dominuje czerwień, symbol władzy królewskiej, a jednocześnie cierpienia i męki.

Krótki artykuł nie wyczerpie wszystkich aspektów katedry Notre-Dame. Może jedynie sygnalizować bogactwo przekazywanych przez nią treści, zasugerować pewne obszary dalszych poszukiwań oraz zaprosić do lektury wybitnych dzieł przedstawiających katedrę. Nic jednak nie zastąpi osobistej konfrontacji i bezpośredniej kontemplacji średniowiecznego cudu architektury. Dlatego, na całe szczęście, mimo zniszczeń pożaru z 15 kwietnia, wciąż można powtórzyć za pisarzem i poetą, że „bez wątpienia dziś nadal jeszcze kościół Najświętszej Marii Panny w Paryżu jest majestatyczną i wzniosłą budowlą"42.

\section{BIBLIOGRAFIA}

Apollinaire G., Alcools suivis de Calligrammes, Paris 2013.

Duby G., Historia kultury francuskiej. Wiek X-XX, tłum. H. Szumańska-Grossowa, Warszawa 1965.

Duby G., Rok Tysięczny, tłum. M. Malewicz, Warszawa 1997.

Duby G., Czasy katedr. Sztuka i społeczeństwo 980-1420, tłum. K. Dolatowska, Warszawa 1986.

Hugo W., Katedra Marii Panny w Paryżu, tłum. H. Szumańska-Gross, Warszawa 2005.

${ }^{41} \mathrm{http}: / /$ ww w.therosewindow.com/pilot/Paris-N-Dame/S-rose-Frame.htm (28.10.2019).

${ }^{42}$ V. Hugo, Notre-Dame de Paris, s. 87, wersja elektroniczna za: https://bibliothequenumerique.tv5monde.com/livre/67/Notre-Dame-de-Paris (28.10.2019). 
Hugo V., Notre-Dame de Paris, wersja elektroniczna.

Hugo V., Préface de Cromwell, Paris 1949.

Kowalski J., Loba A. i M., Prokop J., Dzieje kultury francuskiej, Warszawa 2005.

Panofsky E., Studia z historii sztuki, tłum. J. Białostocki, Warszawa 1971.

Rabelais F., Gargantua i Pantagruel, cz. 1 i 2, tłum. T. Boy Żeleński, Warszawa 1988.

Toman R., Sztuka romańska. Architektura, rzeźba, malarstwo, tłum. R. Wolski, b.m. 2008.

Villon F., Wielki Testament, tłum. T. Boy-Żeleński, Warszawa 1954.

Villon F., Le Grand Testament in: CEuvres complètes de François Villon, Paris 1976.

Wykaz stron internetowych:

https://www.notredamedeparis.fr/la-cathedrale/architecture/la-fleche/

https://www.franceculture.fr/emissions/la-grande-table-1ere-partie/le-cinema-

-paradisio-de-wim-wenders https://www.notredamedeparis.fr/la-cathedrale/

espace-jeunesse/les-tresors-de-notre-dame/les-rosaces/

http://www.pan.poznan.pl/nauki/N_404_09_Knapinski.pdf

https://wolnelektury.pl/katalog/lektura/wielki-testament.html\#anchor-idm13993

1591254224

https://fr.wikisource.org/wiki/Le_Grand_Testament

https://wolnelektury.pl/media/book/pdf/gargantua-i-pantagruel.pdf

http://www.bbc.com/culture/story/20190417-stunning-and-surprising-depictions-of-

notre-dame

https://www.poesie-francaise.fr/gerard-de-nerval/poeme-notre-dame-de-paris.php

https://www.poetica.fr/poeme-1737/theodore-de-banville-amour-angelique/

https://www.poetica.fr/poeme-5676/theophile-gautier-notre-dame/

https://fr.wikisource.org/wiki/Les_Cloches_(Apollinaire)

http://hamlet.edu.pl/przybos-notre-dame

https://www.poetica.fr/poeme-5684/kamal-zerdoumi-notre-dame/

https://ecrivains-publics.fr/wp-content/uploads/2016/10/preface_de_cromwell_--

hugo.pdf

https://www.notredamedeparis.fr/la-cathedrale/espace-jeunesse/les-tresors-denotre-dame/les-rosaces/

http://www.therosewindow.com/pilot/Paris-N-Dame/N-rose-Frame.htm http://www.therosewindow.com/pilot/Paris-N-Dame/W-rose-Frame.htm http://www.therosewindow.com/pilot/Paris-N-Dame/S-rose-Frame.htm https://bibliothequenumerique.tv5monde.com/livre/67/Notre-Dame-de-Paris

\section{Biogram}

Agnieszka Włoczewska ukończyła studia magisterskie w Instytucie Romanistyki Uniwersytetu Warszawskiego w 1999 roku. Od 2006 wykłada na Uniwersytecie w Białymstoku, w Zakładzie Języka Francuskiego. 22 marca 2016 roku Rada Wydziału Neofilologii Uniwersytetu Warszawskiego nadała jej tytuł doktora habilitowanego na podstawie pracy 
monograficznej Teatr Apollinaire'a (Collegium Columbinum, Kraków 2015). Od 2007 prowadziła Spotkania z bajkq francuska, a w latach 2008-2011 - koło teatralne. Obok pracy naukowej zajmuje się także tłumaczeniami beletrystyki. W dorobku naukowo-translatorskim są m.in.: Mały leksykon pojęć i terminów frankofońskich (monografia), posłowia do powieści Balzaka; artykuły: „Apollinaire 1913”, „Murzyńskość, antylskość i kreolizacja, czyli jak ocalić świat postkolonialny od metyzacji. W setną rocznicę urodzin Aimé Césaire'a”, „Egzystencjalizm Kierkegaarda w dramatach Sartre'a. Dialog filozofii i teatru”; przekłady Juliusza Verne'a, Blaise'a Cendrarsa, Apollinaire'a, Ch.-F. Ramuza. e-mail: agnieszka@absyst.com, https://orcid.org/0000-0003-1679-5859 


\title{
Robert Nęcek
}

\author{
Head of the Department of Media Education, University of John Paul II
}

\section{Understanding John Paul II's communication with the contemporary world on the example of Joanna Sobczyk-Pajak's painting}

\author{
Rozumienie komunikacji Jana Pawła II \\ ze światem współczesnym na przykładzie \\ malarstwa Joanny Sobczyk-Pająk
}

\begin{abstract}
The process of interpersonal communication as understood by John Paul II is a reality based on establishing mutual relations and cooperation. Communication requires a specific medium, and in this context the image becomes the communication medium, because the communication of John Paul II is presented on the plane of the image. That is why the papal painting made by Joanna Sobczyk-Pajak is a communication of beauty. John Paul II in a painting, fascinates at every step and in the way in which he amazed the world during his lifetime.

Of course, art is such a dimension of human

life that it can pose questions or answer them.

Everything depends on the imagination of the artist and the recipient himself. It seems, however,

that the painting by the Cracow artist from Podłęże is a call for basic values that make human life beautiful and meaningful. There is no pressure in this painting. Talking to the audience through the painting and serving them manifestations of papal communication, he asks people living today

about the values in their lives, about the sense of beauty, about the liberation of harmony in the heart. In this way, the essence of communication becomes the meeting with people.
\end{abstract}

KEYWORDS: communication, culture, empathy, beauty, painting as a form of communication, message, media, creating relations

\section{ABSTRAKT}

Proces komunikacji międzyludzkiej w rozumieniu Jana Pawła II jest rzeczywistością polegającą na nawiązaniu wzajemnych relacji i współdziałania. Komunikacja wymaga określonego medium, a w tym kontekście medium komunikacyjnym staje się obraz, gdyż na płaszczyźnie obrazu przedstawiona jest komunikacja Jana Pawła II. Dlatego malarstwo papieskie Joanny Sobczyk-Pająk jest komunikacją piękna. Ukazany obrazem Jan Paweł II fascynuje na każdym kroku, fascynuje w taki sposób, w jaki zadziwiał świat za życia. Oczywiście sztuka jest takim wymiarem ludzkiego życia, że może stawiać pytania lub na nie odpowiadać. Wszystko zależy od wyobraźni artystki i samego odbiorcy. Wydaje się jednak, że malarstwo krakowskiej artystki rodem z Podłęża jest wołaniem o podstawowe wartości, które czynią ludzkie życie pięknym i sensownym. W tym malarstwie nie ma żadnej presji. Rozmawiając z odbiorcami poprzez obraz i serwując im przejawy komunikacji papieskiej stawia pytania ludziom współcześnie żyjącym o wartości w ich życiu, o poczucie piękna, o wyzwolenie harmonii w sercu. Tym sposobem istotą komunikacji staje się spotkanie z ludźmi.

\section{SŁOWA KLUCZOWE:}

komunikacja, kultura, empatia, piękno, malarstwo komunikacją, przekaz, media, tworzenie więzi 


\section{INTRODUCTION}

The culture of closeness is the key to establishing interpersonal relations. Although the very phrase "culture of closeness" was created by Pope Francis, the teaching of John Paul II was also characterized in a very visible way. Closeness in word and posture has an extremely rich species load. Above all, it is about the bond of closeness, which is expressed in ordinary everyday communication. By means of communication understood in this way, the awareness of being accepted, understood and loved is liberated in our neighbour ${ }^{1}$. Then - even in pain - joy is born, and this joy is awakened from the "selfless meeting! Someone says: "You are important to me, I love you, I rely on you "' 2 . So what does communication mean? Well, communication "means creating relations between people", in which the tenderness of love manifests itself on every level.

In the context of John Paul II's communication with the world, the painting of the Krakow artist, straight from Podłęże by Joanna Sobczyk-Pająk, appears as one of her forms constituting an artistic expression of a beautiful path that evokes deep emotions and fills with joy ${ }^{4}$. Painting as "art is the fruit of the creative abilities of a human being who, in the face of visible reality, asks questions, tries to discover its deep sense and pass it on in a different language of forms, colours and sounds. Art can express and make visible the human need to explore the invisible, to express the desire and the search for infinity"5.

Being aware of this, it is worth presenting the papal concept of communication, the papal painting of Joanna Sobczyk-Pajak and the manifestations of understanding of papal communication in her art.

${ }^{1}$ Por. R. Nęcek, Od kapłaństwa do społeczeństwa. Wybrane kwestie z nauki społecznej papieża Franciszka, Kraków 2014, s. 84.

${ }^{2}$ Franciszek, Wiarygodni i konsekwentni. Spotkanie z seminarzystami, nowicjuszami i nowicjuszkami (6.07.2013), „L`Osservatore Romano” nr 8-9 (2013), s. 42.

${ }^{3}$ Franciszek, Prawdziwa władza jest służbq, Kraków 2013, s. 400.

${ }^{4}$ Por. Benedykt XVI, Sztuka i kultura umacniaja naszq więź z Panem (Castel Gandolfo, 30.08.2011), „L`Osservatore Romano” nr 10-11 (2011), s. 45.

${ }^{5}$ Tamże, s. 46. 


\section{THE PAPAL CONCEPT OF INTERPERSONAL COMMUNICATION}

The process of interpersonal communication as understood by John Paul II is a reality taking place within a given community and consists in establishing mutual relations and cooperation. The term "to communicate" means "to make something common, to give something to the public, to transfer message, to notify about something" ${ }^{\prime \prime}$. In this way, the essence of communication becomes the meeting with people. There is no social interaction without communication. On the other hand, communication requires a specific medium, i.e. an instrument for transferring information in space and time. It can be a speech or a lecture, a letter or a print, or it can be a satellite link or a painted picture ${ }^{7}$. In other words, communication is an establishment of connection between people through sensorially perceivable means ${ }^{8}$. In this context they will be presented - participation in the process of communication, the message as a way to community and formation to receive beauty.

\section{On the other hand, communication requires a specific medium, i.e. an instrument for transferring information in space and time.}

\section{Participation in the communication process}

Undoubtedly, interpersonal communication is not only a communication of information, but also a communication of a person who communicates a specific content. The more noteworthy the message becomes the content communicated by the artists, because the artists are able to make the image attractive,

${ }^{6}$ Por. Słownik Wyrazów Obcych PWN. Wydanie nowe I, Warszawa 1995, s. 578.

${ }^{7}$ Por. T. Goban-Klas, Komunikowanie i media, w: Dziennikarstwo i świat mediów, red. Z. Bauer, E. Chudziński, wyd. II zm., Kraków 2000, s. 12.

${ }^{8}$ Por. M. Golka, Bariery w komunikowaniu i społeczeństwo (dez) informacyjne, Warszawa 2008, s. 4. 
understandable and encouraging to think deeper through various ways of art ${ }^{9}$. In this way, participation in the creation of culture by art is not possible without communication. It should be emphasized that culture expressed through art becomes a specific way of human existence, which creates "a set of connections between persons living within each community, defining the interpersonal and social character of human existence. The subject and creator of culture is the man who finds his own expression and balance in it"10. This means that participation in communication and culture determines the level of humanity of the human being. The culture expressed in art itself is "communication - not only and not so much between man and the environment, over which man is called to rule, but also between man and man"11. It is not by chance that Pope Benedict XVI, the successor of Pope Wojtyla, noted that the desire to communicate is nothing more than "a modern expression of the basic and constant tendency of man to cross himself in order to establish relationships with other people. For when we open ourselves up to others, we satisfy our deepest needs and achieve the fullness of humanity"12. Such an approach to the matter allows us to understand the essence of communication as a message, creating culture, helping to understand the world, creating interaction with others and gathering social memory ${ }^{13}$. Therefore, communication through art is something very important, because it shapes the common good of the society, which combines participation and cooperation, which is the feature of person and society.

${ }^{9}$ Por. Jan Paweł II, Orędzie na XVI Światowy Dzień Środków Społecznego Przekazu - 1982. Środki społecznego przekazu a problemy ludzi starszych, w: Jan Paweł II, Dzieła zebrane, t. 4, Kraków 2007, s. 877.

${ }^{10}$ Jan Paweł II. Orędzie na XVIII Światowy Dzień Środków Społecznego Przekazu - 1984. Środki społecznego przekazu pomostem między wiarq i kultura, w: Jan Paweł II, Dzieła zebrane, t. 4, Kraków 2007, s. 882.

${ }^{11}$ Tamże, s. 883.

${ }^{12}$ Benedykt XVI, Nowe technologie, nowe relacje. Trzeba rozpowszechniać kulturę szacunku, dialogu i przyjaźni. Orędzie na 43 Światowy Dzień Środków Społecznego Przekazu, „L'Osservatore Romano" nr 3 (2009), s. 5.

${ }^{13}$ Por. M. Golka, Bariery w komunikowaniu i społeczeństwo (dez)informacyjne, Warszawa 2008, s. 4. 


\section{Message as a route to community}

The papal understanding of communication with the world is based on a vision of a message leading to community, and the artist is undoubtedly surrounded by a circle of people enchanted by his sensitivity to beauty. John Paul II, speaking about the community of people, points to selfless love as the basis. It is the love for art and the love for the artist that leads to the formation of a community of people who are united by beauty and its depth. The artist's love for beauty can release the process of feelings communication for the viewer, looking for the meaning and self-fulfilment. Although the way of communicating feelings can sometimes cause problems in interpersonal relations, the need to share them is something proper and worthy of desire.

\section{The artist's message is a specific process of communicating beauty by arousing deeper feelings.}

The artist's message is a specific process of communicating beauty by arousing deeper feelings. This means that his message leads to community and creates goodness when aesthetics is combined with ethics. Then the aim of an artist's work is always good, and his fascination with the work of art has no neutral value. To create culture through art is always to give personal testimony "when a concrete person shares his faith in the risen Lord with others - it has a significant meaning, just like other traditional forms of proclaiming the Word of God"14. In this way, the artist's gaze reaches much deeper than the average, and it is a free gaze, and this gaze is used by others. His imaging language of communication in all circumstances is based on duc in altum - go deep, and where there is depth, there is community.

${ }^{14}$ Por. Jan Paweł II, Orędzie na XXXIV Światowy Dzień Środków Społecznego Przekazu 2000, w: Jan Paweł II, Dzieła zebrane, t. 4, Kraków 2007, s. 933. 


\section{Formation for the reception of beauty}

John Paul II reminded us that "in a culture that feeds on passing phenomena, there is a danger that people will be inclined to attribute greater significance to facts than to values"15. Meanwhile, there is an urgent need to shape man's sensitivity to beauty. In "Letter to Artists" the Pope directly noted that the world needs artists, because in the vast panorama of culture they secure a sublime form of art, which is the formation to perceive beauty. The point is that sensitivity to beauty becomes a valuable service for the common good, because a sensitive viewer builds a sensitive society ${ }^{16}$. This means that "every authentic form of art is a peculiar way of accessing the deeper reality of a man and the world"17. It also means that the artist's ministry is associated with responsibility for the spiritual development of the recipient. For this reason, it is worth supporting the formation for the reception of beauty in various ways, because through beauty the life of each nation is renewed ${ }^{18}$. Additionally, the artist's ministry is usually undervalued financially, and in the era of the free market it becomes more and more difficult to obtain patronage. Archbishop Józef Życiński says it bluntly: "Our sensitivity to beauty does not usually bring us any benefits in the evolutionary struggle for existence. No one goes to the philharmonic to impress their neighbours or to have an opinion of a man of culture in the circle of their closest relatives. We go because we love the beauty of music, although there are no measurable benefits from this love"19. In this context, Karol Wojtyła was raised from an early age to a very personal reference to beauty. What is more, he interpreted the focus on beauty in the spirit of Norwidian love ${ }^{20}$. Therefore, the key to the sensitivity to beauty are the words of the bard: "What do you know about beauty?..." ... „the shape is Love"21. Being aware of this, Pope Wojtyła reminded us that through the paths of art one can "transfer

${ }^{15}$ Jan Paweł II, Orędzie na XXXVI Światowy Dzień Środków Społecznego Przekazu - 2002, w: Jan Paweł II, Dzieła zebrane, t. 4, Kraków 2007, s. 938.

${ }^{16}$ Por. Jan Paweł II, List do artystów, Watykan 1999, nr 3-4.

${ }^{17}$ Tamże, nr 6.

${ }^{18}$ Por. Jan Paweł II, List do artystów, Watykan 1999, nr 3-4.

${ }^{19}$ J. Życiński, Wartości w eterze, Lublin 1999, s. 23.

${ }^{20}$ Por. Z. S. Szpecht-Abramiuk, Piękno $w$ doświadczeniu egzystencjalnym Karola WojtyłyJana Pawła II, „Warszawskie Studia Teologiczne” nr 1 (2011), s. 29.

${ }^{21}$ C. K. Norwid, Promethidion: Bogumit, w: Pisma wybrane, t. 2, Poematy, Warszawa 1968, w. 109. 
human souls from the sensual world into eternal reality"22. It must be stated, therefore, that the experience of beauty is not only aestheticism, but above all the moment of experiencing love, when the beauty becomes a chance for love ${ }^{23}$.

\section{PAPAL PAINTING BY JOANNA SOBCZYK-PAJAK}

It should be noted that art can sometimes use a better message than other media, although to a large extent the artist's message is an individual one. From this perspective, one of the forms of communication is painting. The message proposed by the artists often becomes a different perception of the world, devoid of routine and sophistication. Therefore, in this context, it is worth looking at the painting of the Cracow artist, like Joanna Sobczyk-Pająk from Podłęże. Therefore, the following will be discussed: painting as a form of communication and selected painting poses of John Paul II in its approach.

\section{Painting as a form of communication}

Undoubtedly, painting is conducive to the establishment of interpersonal relations, and more precisely to the relations between the artist and the recipient of her work. Communication in art has always existed, because artists have always tried to convey the message of beauty through their paintings. Therefore, in case of Joanna Sobczyk-Pajak, the image becomes a form of communication with the world. By painting papal shots of John Paul II, the painter preserves the memory of the great pope, takes care of it and gives it to the audience to think about. Her work is expressed in oil painting and digital painting.

\section{Oil painting}

In one of her articles, the painter states that it is difficult to imagine communication today without a visual form"24. Painting is a perfect form of communication with the world, and at the same time the most traditional and well-known form of painting on canvas. It is also considered the most noble form. It is worth

${ }^{22}$ Jan Paweł II, List do artystów, Watykan 1999, nr 7.

${ }^{23}$ Por. Z. S. Szpecht-Abramiuk, Piękno $w$ doświadczeniu egzystencjalnym Karola WojtyłyJana Pawła II, „Warszawskie Studia Teologiczne” nr 1 (2011), s. 29.

${ }^{24}$ Por. J. Sobczyk-Pająk, Wizerunek współczesnego świętego $w$ malarstwie forma komunikacji ze światem, w: Św. Joanna Beretta Molla. Komunikacja i społeczne oddziaływanie, red. R. Nęcek, J. Sobczyk-Pająk, Kraków 2019, s. 89. 
noting that the time of painting oil paintings is an extended time, and everything depends on the size of the painting - for example, the painting of St. John Paul II placed in the side altar in the parish church of the Blessed Virgin Mary, Queen of Poland in Podłęże was painted for more than half a year.

You can use a brush to express yourself without words, because the painting speaks for itself. One of the painting techniques of Joanna Sobczyk-Pajak is oil painting. In her painting message, she tries to transfer emotions and feelings onto the canvas. It should be noted that a brush is a traditional painting tool, and oil paintings are painted with pigments bound by drying oil, which includes linseed oil, poppy seed oil or safflower oil. It is worth noting that oil painting allows retouching paintings by applying successive layers of paint to the painting.

The artist uses different oils in the same painting, depending on the expected effects. The oil itself can be boiled in pine resin in order to create a lacquer, valued for its gloss. The long drying time of oil paints allows the artist to change the colours or shapes painted on canvas. The paint dries through the oxidation process. The average period of drying is two weeks, although conservators claim that oil paintings in traditional technology become completely dry only in the period of 60-80 years.

Digital painting

The second painting form of Joanna Sobczyk-Pajak is digital painting. It is a new form of art. The artist uses painting techniques to create a digital image simply on a computer. It is a way of creating picture using computer tools. These include: Photoshop, a complex graphic program, a tablet with a stylus and other equally important programs. A sketch is made on paper, transferred to a tablet, on which the whole drawing is outlined in such a way that its contours are placed on the screen. Thanks to the digital program, the artist can create her own brush style. Thanks to digital painting, the painter from Podłęże combines two worlds: the world of art and the world of computer science. It is an attempt to fill the gap between traditional and digital painting. It is not by chance that John Paul II - taking into account the novelty of the message also in art - noted that "new forms of culture and art appear today. They become a powerful stimulus for believers to search for a more mature faith and to bear witness to it with a new faith"25.

${ }^{25}$ Jan Paweł II, Przesłanie do uczestników II Zgromadzenia Plenarnego Papieskiej Komisji ds. Kościelnych Dóbr Kultury, w: Jan Paweł II. Dzieła zebrane, t. 5, Kraków 2007, s. 312. 


\section{Selected painting poses of John Paul II}

The papal painting of Joanna Sobczyk-Pajak is a part of her life. Through her painting, she communicates certain information to the viewers and tries to interact with them. Communication, being a part of everyday life, articulates emotions, suffering, reverie, joy or fear. The artist herself will add that the creator of the image, by obtaining a specific form, makes " $a$ work of art a carrier of ideas. The convention applied and the artist's personality give the work its character of a language. Therefore, it is able to express hidden contents, becoming an important link in the process of communication, evoking recipient's resonance" ${ }^{26}$. Her papal painting does not provoke, does not teach anyone, but encourages to think and pay attention, and above all, it proposes. From the whole painting spectrum of the Cracow artist, the following paintings will be presented: a blessing from a Vatican window, with hands spread across Poland and a hand covering the face.

\section{Blessing from the Vatican Window}

To bless someone is to wish him everything good for every day. John Paul II is shown in the open Vatican window. The painting depicts a saint facing away from the recipient, who stands and blesses. It is impossible not to stop at the vernissage by passing by. The colours are warm and friendly. You can see freedom and dynamics in the combination of colors and shapes. Different shades of green merge, which is considered to be a neutral colour, a middle way between charming blue and suggestive red. However, the same green symbolizes the vegetation that is awakening to life. For this reason, it is associated with hope, and hope is a component of the blessing.

Looking at the picture, you can also see a rose piercing through various shades of grey. This colour is associated with passion and empathy, and even with love, which may mean that there is no love without empathy, nor empathy without love, but love and empathy are also the components of the blessing. After all, the white of the papal cassock, symbolizing innocence, also speaks of a new beginning and is the opening of a new card of life.This means that the whiteness is also expressed in the blessing. It also means that the Blessing Pope encourages a new quality of life. The artist seems to be clearly encouraging this new quality of life.

${ }^{26}$ J. Sobczyk-Pająk, Wizerunek współczesnego świętego w malarstwie formą komunikacji ze światem, w: Św. Joanna Beretta Molla. Komunikacja i społeczne oddziaływanie, red. R. Nęcek, J. Sobczyk-Pająk, Kraków 2019, s. 95. 
With hands spread across Poland

The painting depicts John Paul II covering the whole of Poland with his hands. The hands spread are open to the issues and problems of the nation and concern with them. It is a closeness full of empathy and understanding. In the distance you can see gray colours and piling clouds of gray smoke, although in a stronger shade. Greyness is a symbol of a certain insecurity, and being neutral is conducive to solving disputes. The white figure of the Pope and his hands spread out are also a symbol of intercession with God and a request to Him that His providence should cover the whole country. Certainly, this image speaks to people of all epochs, because there are always problems of the country, although they are different depending on the time and historical context. Of course, looking at the paintings of the Cracow artist, it should be noted that what painting "communicates to the viewer is also dependent on him/her"27.

With a hand that covers the face

The artist depicts a pope praying. His face, covered by his hand, is sunk in prayer. Here is a holy man focused on a conversation with the absolute, with God. It is interesting to see Joanna Sobczyk-Pajak, who emphasizes that "one cannot let oneself be carried away by one's own painting vision if one wants the painting to reflect the saint's person and communicate the contents that he or she passed on during his or her lifetime"28. The colours of this work are shrouded in grey, intertwined with the white of the Holy Pope. The contours of the hand clearly outlined show the ring of the fisherman in the shape of a small cross. The golden or gold ring expresses love for God, that is, love is a ring, and the ring has no end. At the same time it is a sign of attachment, trust and covenant. One could boldly emphasize the great Pope's intercession prayer and his union with God. In this way, beauty is revealed, which "undoubtedly becomes the goal of the act of communication, and beauty is what makes man better and more noble"29.

${ }^{27}$ Tamże, s. 96.

${ }^{28}$ J. Sobczyk-Pająk, Wizerunek współczesnego świętego $w$ malarstwie formą komunikacji ze światem, w: Św. Joanna Beretta Molla. Komunikacja i społeczne oddziaływanie, red. R. Nęcek, J. Sobczyk-Pająk, Kraków 2019, s. 98.

${ }^{29}$ J. Sobczyk-Pająk, R. Nęcek, Komunikacja piękna. Papieskie wernisaże w Makao i w Krakowie, Krakow 2019, s. 5-6. 


\section{THE MANIFESTATIONS OF PAPAL COMMUNICATION IN THE PAINTING MESSAGE OF JOANNA SOBCZYK-PAJĄK}

Image is a universal mean of communication, and "The Church needs art. It must make the spiritual, invisible, divine reality visible and even attractive as far as possible. Therefore, it must express in understandable formulas what in itself is inexpressible"30. This means that the words on which communication is based are simply not enough. Therefore, the image acquires an analogous function to the presented message ${ }^{31}$. One can even say that Joanna Sobczyk-Pajak educates with an image that becomes an essential element of a deeper perception of the world and communication with it. In this perspective, in the painting of the artist one can notice the manifestations of papal communication with God, human being and the nature. In support of these words, the following will be presented: prayer at the Wailing Wall of Jerusalem, contemplative amazement on the mountains, a smile as the beginning of communication and listening reflected in the eyes.

\section{Prayer at the Wailing Wall in Jerusalem}

The picture of the pope standing in front of the Jerusalem Wailing Wall is impressive. The Holy Pope communicates with God in a quiet gesture of folding a prayer card in the gap of the Wall. Here is a man in white against the background of various shades of gray, submerged in divine dialogue. Slightly humped, his head bent down. Against the background of not clear colours, white is visible in full outlines. Different intensity of colours increases the clarity of the image and helps to distinguish the essential planes of life from each other. This means that the language of colours and shapes supports the intuition of the viewer, they try to introduce it into the world of the spirit of the immaterial, so that it does not get lost in the material. Communication between what is visible and what is invisible.

This image has an exceptional impact on the senses, and its communicativeness brings the viewer closer to the spiritual world. In this case, the image becomes a message of beauty, what brings us closer and what we long for. It is worth

${ }^{30}$ Jan Paweł II, List do artystów, Watykan 1999, nr 12.

${ }^{31}$ Por. M. Strączyńska, Synergia obrazu i tekstu w projektowaniu komunikacji wizualnej. Poszukiwanie i analiza najważniejszych przykładów skutecznego łączenia obrazu i tekstu w kontekście edukacyjnym, Maszynopis - doktorat, Uniwersytet Śląski, Wydział Artystyczny, pod kierunkiem dr. hab. Łukasza Klisia, Cieszyn 2017, s. 5. 
noting in this context that "contemporary man should be able to read everywhere from archaeological excavations to the most modern forms of Christian art - the history of the Church, so that thanks to this it would be easier for him to see the mysterious beauty of God's saving plan"32.

\section{Contemplative amazement on the mountains}

As an artist, Joanna Sobczyk-Pajak is well aware that contemplation of mountains leads to contemplation of God. The author of the painting clearly appreciates what is usually underestimated in life - communication with God and adoration of beauty. When beauty is perceived as beauty, a sense of adoration occurs spontaneously. Then one would like to embrace the whole fullness with one's eyes, looking at it and admiring it in silence, because beauty is there to delight, and the fullness of this beauty to encourage adoration. The white silhouette of Pope Wojtyla, leaning against a wooden stick and reflecting on the water surface, directly calls to the recipient: come closer and contemplate the face of the Almighty. On the one hand, the beauty of the mountains intimidates, and on the other hand, it encourages to admire. When beauty is discovered in its entirety, joy and a feeling of respect and even greater feeling of gratitude appear. Then a bond is born open to infinity and common cooperation. When painting this picture, the author was aware of the fact that contemplation is a real desire to come near what is beautiful.

\section{Smile as an introduction to communication}

This image is clearly suggestive. Here is the Pope smiling at the people he meets and showing his coming from the meeting. A smile is an invitation to dialogue and communication. Of course, a smile coming from the heart is a decoration of a man's ordered interior. That is why Joanna Sobczyk-Pajak had to get to know the Pope's biography well in order to be able to show so realistically the papal expression of joy. The artist herself emphasizes that "it is impossible to paint a figure well without knowing its life story and the message it brings"33.

${ }^{32}$ Jan Paweł II, Przesłanie do uczestników II Zgromadzenia Plenarnego Papieskiej Komisji ds. Kościelnych Dóbr Kultury, w: Jan Paweł II. Dzieła zebrane, t. 5, Kraków 2007, s. 312.

${ }^{33} \mathrm{~J}$. Sobczyk-Pająk, Wizerunek współczesnego świętego $w$ malarstwie formą komunikacji ze światem, w: Św. Joanna Beretta Molla. Komunikacja i społeczne oddziaływanie, red. R. Nęcek, J. Sobczyk-Pająk, Kraków 2019, s. 98. 
The face of John Paul II clearly radiating with sunlight, eyes slightly squinted and expressing warmth beating from the inside. A slightly tousled hair and the hand of a met man placed on his shoulder clearly suggest a fascinating atmosphere of the meeting and minimized distance. A smile that captivates a good person and leaves the other person's heart refreshed, calm and rich of willingness to live. This image appeals to the imagination and strikes with the simplicity of the message telling the audience that a smile can be a prelude to communication.

\section{Listening reflected in the eyes}

Undoubtedly, eyes are the most important deceit of man, thanks to which you can find yourself in the surrounding world. The artist has shown them in an exceptional way in all their sharpness. One could risk a statement that only eyes are clear, everything else is shrouded in light mist of various grayscale varieties. The eyebrows are wrinkled and the eyes are gazed, as if the pope was trying to listen carefully. Who? When taking into account folded hands, it seems to be God. Anyway, when a man can be focused on God, he can also focus on another man.

In this way the recipient can receive a simple message - focusing on the other and the ability to listen to it is an essential condition for successful communication and mutual understanding. There must be no hurry in listening, there must be a stop in listening. It should be emphasized that listening to the Pope's eyes is a sign of longing for concentration, for listening, for opening up to one's neighbor. It is a longing for a human and heartfelt conversation. It is not by chance that people who are enchanted by people look into each other's eyes and read what others are unable to read.

\section{CONCLUSION}

To sum up, it should be stated that the papal painting of Joanna Sobczyk-Pajak is a communication of beauty. John Paul II in a painting, fascinates at every step and in the way in which he amazed the world during his lifetime. Of course, art is such a dimension of human life that it can pose questions or answer them. Everything depends on the imagination of the artist and the recipient himself. It seems, however, that the painting by the Cracow artist from Podłęże is a call for basic values that make human life beautiful and meaningful. There is no pressure in this painting. Talking to the audience through the painting and serving them manifestations 
of papal communication, he asks people living today about the values in their lives, about the sense of beauty, about the liberation of harmony in the heart.

\section{John Paul II in a painting, fascinates at every step and in the way in which he amazed the world during his lifetime.}

So it is not accidentally that John Paul II, addressing the Pontifical Commission for Church Cultural Assets, stated that "one should also take care of new creativity, establishing personal contact with creators, showing them greater attention and readiness to help, so that also in our era, works are created that will be a testimony of faith and the presence of the Church in the history of the world"34.

\section{REFERENCES}

Benedykt XVI, Sztuka i kultura umacniaja naszq więź z Panem (Castel Gandolfo, 30.08. 2011), „L'Osservatore Romano” nr 10-11 (2011), s. 45.

Benedykt XVI, Nowe technologie, nowe relacje. Trzeba rozpowszechniać kulturę szacunku, dialogu i przyjaźni. Orędzie na 43 Światowy Dzień Środków Społecznego Przekazu, „L'Osservatore Romano” nr 3 (2009), s. 5.

Franciszek, Wiarygodni i konsekwentni. Spotkanie z seminarzystami, nowicjuszami i nowicjuszkami (6.07.2013), „L’Osservatore Romano” nr 8-9 (2013), s. 42-43.

Franciszek, Prawdziwa władza jest służba, Kraków 2013.

Goban-Klas T., Komunikowanie i media, w: Dziennikarstwo i świat mediów, red. Z. Bauer, E. Chudziński, wy. II zm., Kraków 2000, s. 11-31.

Golka M., Bariery w komunikowaniu i społeczeństwo (dez) informacyjne, Warszawa 2008.

Jan Paweł II, Orędzie na XVI Światowy Dzień Środków Społecznego Przekazu - 1982. Środki społecznego przekazu a problemy ludzi starszych, w: Jan Paweł II, Dzieła zebrane, t. IV, Kraków 2007, s. 875-878.

Jan Paweł II, Orędzie na XVIII Światowy Dzień Środków Społecznego Przekazu - 1984. Środki społecznego przekazu pomostem między wiara i kultura, w: Jan Paweł II, Dzieła zebrane, t. IV, Kraków 2007, s. 882-885.

Jan Paweł II, Orędzie na XXXIV Światowy Dzień Środków Społecznego Przekazu - 2000, w: Jan Paweł II, Dzieła zebrane, t. IV, Kraków 2007, s. 932-934.

${ }^{34}$ Jan Paweł II, Przesłanie do uczestników II Zgromadzenia Plenarnego Papieskiej Komisji ds. Kościelnych Dóbr Kultury, w: Jan Paweł II. Dzieła zebrane, t. 5, Kraków 2007, s. 312. 
Jan Paweł II, Orędzie na XXXVI Światowy Dzień Środków Społecznego Przekazu - 2002, w: Jan Paweł II, Dzieła zebrane, t. IV, Kraków 2007, s. 937-939.

Jan Paweł II, List do artystów, Watykan 1999.

Jan Paweł II, Przesłanie do uczestników II Zgromadzenia Plenarnego Papieskiej Komisji ds. Kościelnych Dóbr Kultury, w: Jan Paweł II. Dzieła zebrane, t. V, Kraków 2007, s. 311-313.

Nęcek R., Od kapłaństwa do społeczeństwa. Wybrane kwestie z nauki społecznej papieża Franciszka, Kraków 2014.

Norwid C.K., Promethidion: Bogumit, w: Pisma wybrane, t. II, Poematy, Warszawa 1968.

Słownik Wyrazów Obcych PWN, Wydanie nowe I, Warszawa 1995.

Sobczyk-Pająk J., Wizerunek współczesnego świętego w malarstwie formq komunikacji ze światem, w: Św. Joanna Beretta Molla. Komunikacja i społeczne oddziaływanie, red. R. Nęcek, J. Sobczyk-Pająk, Kraków 2019, s. 89-99.

Sobczyk-Pająk J., Nęcek R., Komunikacja piękna. Papieskie wernisaże w Makao i w Krakowie, Kraków 2019.

Strączyńska M., Synergia obrazu i tekstu w projektowaniu komunikacji wizualnej. Poszukiwanie i analiza najważniejszych przykładów skutecznego łączenia obrazu i tekstu w kontekście edukacyjnym, Maszynopis - doktorat, Uniwersytet Śląski, Wydział Artystyczny, pod kierunkiem dr. hab. Łukasza Klisia, Cieszyn 2017.

Szpecht-Abramiuk Z.S., Piękno $w$ doświadczeniu egzystencjalnym Karola Wojtyły - Jana Pawła II, „Warszawskie Studia Teologiczne” nr 1 (2011), s. 29.

Życiński J., Wartości w eterze, Lublin 1999.

\section{Biogram}

Robert Nęcek - ksiądz archidiecezji krakowskiej, doktor habilitowany nauk społecznych, kierownik Katedry Edukacji Medialnej w Instytucie Dziennikarstwa i Komunikacji Społecznej na Wydziale Nauk Społecznych Uniwersytetu Papieskiego Jana Pawła II. Konsultor Rady ds. Środków Społecznego Przekazu Konferencji Episkopatu Polski. W latach 2005-2016 rzecznik prasowy Archidiecezji Krakowskiej. Na wniosek Komisji ds. Nagród Rektorskich UPJPII rektor przyznał mu nagrodę za wybitne osiągnięcia dydaktyczne i organizacyjne $(2010,2017)$. Autor wielu artykułów naukowych w Polsce, Niemczech, Austrii, na Słowacji, w Indiach, Hiszpanii i kilku książek naukowych w Polsce i we Włoszech. Wyróżniony medalem Mater Verbi. W 2016 roku odznaczony złotą odznaką św. Floriana Mazovia II klasy za wyjątkową skuteczność i kompetencje medialne. Laureat nagrody Feniksa Specjalnego 2017.

e-mail: robert.necek@upjp2.edu.pl,https://orcid.org/0000-0001-8576-9908 


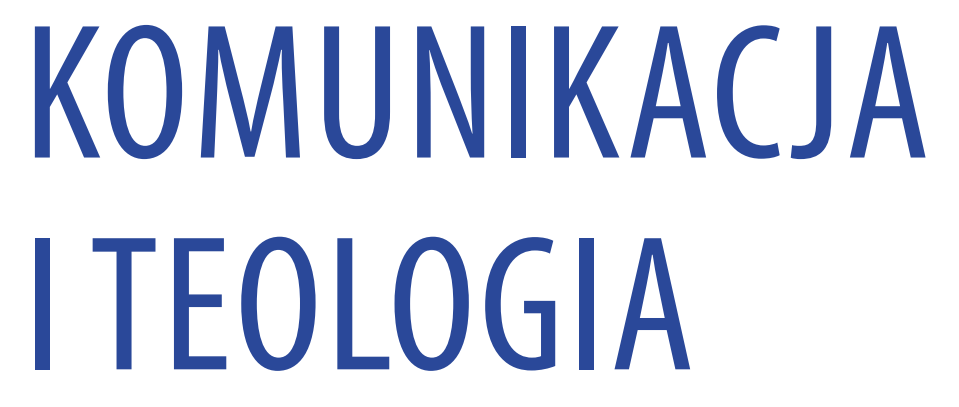

KULTURA - MEDIA - TEOLOGIA 39/2019 


\title{
Tomasz Kopiczko
}

\author{
Uniwersytet Kardynała Stefana Wyszyńskiego
}

\section{Catechesis and new evangelization in the face of contemporary challenges of social communication}

\section{Katecheza i nowa ewangelizacja wobec współczesnych wyzwań komunikacji społecznej}

\begin{abstract}
The article is the outcome of pending research. It raises a broad and complex issue of new evangelization and catechesis in the face of contemporary challenges of social communication. Pursuant to the framework of a research project, this article juxtaposes Polish and Italian literature in recent years. The effect of the scientific research is presented in three points. The first one sets out contemporary challenges of social communication. The next one presents a contemporary illustration of evangelization and catechesis. The last one sets forth concrete rules and solutions. Amongst them we can list the following ones: appropriate order of ministry - catechesis should be preceded by evangelization; the whole work of the Church should have a positive message and lead to hope; preachers and religion teachers should be required to testify with authentic faith and dynamic engagement.

KEY WORDS: catechesis, evangelization, social communication
\end{abstract}

\begin{abstract}
ABSTRAKT
Artykuł jest efektem prowadzonych badań. Podejmuje szerokie i skomplikowane zagadnienie nowej ewangelizacji i katechezy wobec współczesnych wyzwań komunikacji społecznej. Zgodnie z założeniami projektu badawczego artykuł zestawia literaturę języka polskiego i języka włoskiego z ostatnich lat. Efektem przeprowadzonych poszukiwań naukowych jest przedstawienie zagadnienia w trzech punktach. Pierwszy prezentuje współczesne wyzwania komunikacji społecznej. Kolejny przedstawia współczesne ujęcie zagadnień: ewangelizacji i katechezy. Ostatni punkt jest propozycją konkretnych zasad i rozwiązań. Pośród nich wyróżnić można: odpowiednie uporządkowanie całej posługi - katecheza ma być poprzedzona ewangelizacją; całe dzieło posługującego Kościoła powinno mieć pozytywny przekaz i prowadzić do nadziei; przed ewangelizatorami i katechetami należy stawiać wymagania autentycznej wiary i dynamicznego zaangażowania.
\end{abstract}

\section{SŁOWA KLUCZOWE:}

katecheza, ewangelizacja, komunikacja społeczna 


\section{INTRODUCTION}

In 1971, so less than 50 years ago, Klemens Tilmann began his scientific article devoted to religious education with the description of some situation: „A threeyear-old Peter is playing with blocks, while his mother is sitting on a couch busy with sewing. Suddenly he leaves his blocks on the floor, comes up to his mother and wants to climb onto her lap. The mother puts away her work and lets him sit on her lap. He hugs his mum and says: mummy I love you so much. She also hugs her son and says: Oh Peter, I also love you very much. How lovely that we love each other so much”. After a while she adds: „How good God must be if He bestows His love upon us. Next she kisses her son. After a while happy Peter comes back onto the floor and to his toys"1.

A traditional model of upbringing and communication that was in force by the first half of the XX century put a real person (implicitly a family) in the first place. A wide spectrum of social, cultural and communication changes led to a situation in which the mass media have become a leading „educator” or a partner in communication. This rule also applies to the education in faith. A scene described in an article from 1971 seems to be improbable these days, and the method of communication seems naive. This change is well described through a shift from a traditional question: „What to do in order to attain salvation?” to a modern reflection: „What is the most important for me and for others?"2.

This paper does not aim at discussing the contemporary model of religious education, but it wants to draw attention to contemporary challenges which occur in the course of evangelization and catechesis. It is the result of statutory research which invites to further discussion and scientific analysis. The research has been focused on catechesis and new evangelization in the face of contemporary challenges of social communication. The author's intention is to juxtapose Polish and Italian realities. The framework of the research project does not concentrate on differences in approaching the subject in Italy and in Poland, but it is meant to obtain a broader perspective of the problem and involve a wider variety of literature.

\footnotetext{
${ }^{1}$ K. Tilmann, Wychowanie religijne dawniej i dziś, „ColletaneaTheologica” 41(1971) 2, s. 29.

${ }^{2}$ Cf. B. Wieczorek, Wokół religii mediów, „Kultura - Media - Teologia” 11 (2012), s. 19.
} 
The outcome of the scientific query thereof is the presentation of the subject in three points. The first will outline contemporary challenges of social communication. The next will show a contemporary illustration of evangelization and catechesis. The last will set forth concrete rules and solutions, the application of which seems to be justified. The latest documents of the Church and selected Polish and Italian literature (if possible, the recent publications) constitute the sources of the research. The method of the research consists in the elaboration of the sources and a coherent presentation of the conclusions and postulates.

\section{New challenges of social communication}

The process of communication is one of the oldest processes. It has been accompanying a human being since they started to get organized and form groups. In this day and age it is impossible to imagine a society which does not communicate. It might be considered that communication constitutes the basis and foundation of a contemporary society. A notion of social communication may be defined in many ways. Charles Cooley, one of the precursors examining this area of science defined communication as "a mechanism thanks to which human relationships exist and develop and symbols created by human brain are passed on in space and retained in time" ${ }^{3}$. Relating to a recently formed universal definition, we may state that social communication is ,a process of communication between individuals, groups or institutions. Its aim is to exchange thoughts, share the knowledge, information and ideas"4.

This process has many features that define it and determine its effectiveness. A communication process always takes place in a given context. It is creative, dynamic, constant, symbolic, interactive, conscious, deliberate and irrevers$i^{i b l e}{ }^{5}$. A contemporary model that determines the functioning of a communication process bears a number of challenges. A human being exists in the centre of the reality created by a communication process. Man is both a creator and a recipient of messages. Communication chaos takes place in a human being. It is man that is subject to all sorts of stimuli from the world of culture, politics, entertainment,

${ }^{3}$ J. Nikolajew, Jak usprawnić komunikację w przestrzeni społecznej, „Master of Business Administration" 1/2011 (116), s. 45.

${ }^{4}$ B. Dobek-Ostrowska, Podstawy komunikowania społecznego, Wrocław 2004, s. 13.

${ }^{5}$ Cf. W. Głodowski, Komunikowanie interpersonalne, Warszawa 2006, s. 16-26. 
labour, and religious space. Modern world goes through such a rapid technological and communication transformation that we cannot even speak about a generational change ${ }^{6}$. The changes that take place in the development of new media and communication technologies do not reflect even a decade. Those changes, however, do not reflect the way of life and the functioning of all the people in the macro scale. They usually refer to a young generation ${ }^{7}$.

\section{the biggest challenges will be a search for the answer to the following phenomena: firstly, a media character of religiousness and the presence of it in the media. Secondly, an adventure style of life, which consequently leads to superficial human relationships. Thirdly, visual communication plays a prime role (a word has been replaced by an image}

A panorama of challenges and difficulties facing contemporary social communication is wide and comprehensive. For the needs of this elaboration, the scope of research has been narrowed to the area of the transmission of faith, evangelization and catechesis. Here the biggest challenges will be a search for the answer to the following phenomena: firstly, a media character of religiousness and the presence of it in the media. Secondly, an adventure style of life, which consequently leads to superficial human relationships. Thirdly, visual communication plays a prime role (a word has been replaced by an image) ${ }^{8}$.

${ }^{6}$ Cf. T. Huk, Pedagogika medialna. Aspekty społeczne, kulturowe i edukacyjne, Kraków 2014, s. 9-15.

${ }^{7}$ Cf. J. Pyżalski, Agresja elektroniczna i cyberbullying jako nowe ryzykowne zachowania młodzieży, Kraków 2012, s. 10-14; J. Przybyłowski, Komunikacja pastoralna, „Warszawskie Studia Pastoralne" 12 (2017), s. 7-27.

${ }^{8}$ Cf. B. Wieczorek, Wokół religii mediów, „Kultura - Media- Teologia” 11(2012), s. 1831; M. Eliade, Sacrum a profanum: o istocie sfery religijnej, Warszawa 2011; P. Boschini, Dire Dio nel mondo secolarizato, w: Un pensiero aperto sull'evangelizzazione, red. M. Marcheselli, 


\section{A media character of religiousness}

Modern sociology describes a phenomenon which consists in leaving an institutionalized religiousness. Religion becomes „a manifestation of individual secularization”. In such religiousness „without the Church”, the institution does not play an important part. Neither personal nor inner experience of transcendent God matters. What matters is immanent sensation. Due to this, religiousness itself becomes a product which sells well in the media. The media get also engaged in questioning and undermining moral norms and values arising from the gospel $^{10}$.

The media, which by their very nature, are a dynamic reality lead to the socalled medialization of religious messages. It is a complex social process, induced by a growing importance of the mass media, which leads to the transfer of the activities from the real-life reality into a virtual one. In the long run it may even result in shaking or altering certain values ${ }^{11}$. On the other hand, the people who participate in religious events contribute to them being seen as media events. ${ }^{12}$. This phenomenon consists in publishing information, photos and online broadcasts in social media. From the point of view of promotion it seems quite right. However, it also has a side effect. Sacred reality consisting in intimate experience is equalized with other information available online. It is also difficult to mark borders between being a creator and a recipient. Modern social or communication plat-

Bologna, 2019, s. 115-138; J. L. Moral, Modernità e cambio epocale. Prospettive culturali e teologiche con temporanee, Roma 2019; C. Meneghetti, Elementi della teologia della comunicazione, Padova 2015, s. 31-48; G. Filoramo, Religione e religioni, Milano 2014; A. Spadaro, Cyberteologia. Chrześcijaństwo w dobie Internetu, Kraków 2013, s. 5-17.

${ }^{9}$ Cf. J. Mariański, Religia i religijność w zsekularyzowanych społeczeństwach, „Zeszyty Naukowe KUL" 59 (2016) 4, s. 4.

${ }^{10}$ Cf. Tamże, s. 3-26.

${ }^{11}$ Cf. A. Zduniak, Duchowość w epoce mediów elektronicznych, w: Media i religia. Nowy kontekst komunikacji, red. R. Sierocki, M. Sokołowski, A. Zduniak, Toruñ 2016, s. 38-41; J. Iwanicki, Medializacja treści religijnych w kulturze internetowej i popularnej, „Humaniora. Czasopismo Internetowe" 18 (2017) 2, s. 17-28.

${ }^{12}$ An example of this way of thinking might be an event , which took place during baptism - when a priest took a little baby out of water and lifted them up, a five-year-old brother of a baptised child shouted with excitement: „The Lion King”. The baptism became an important religious event for that boy thanks to which he referred the whole ceremony to a well-known scene from a famous cartoon” (B. Wieczorek, Wokół religii mediów, „Kultura - MediaTeologia" 11(2012), s. 31). 
forms give a chance to comment on and co-create information. There comes a risk of blurring its initial character. It results in a phenomenon which might be defined as „pop religion”. Pop religion is based on the fact that a religious message is replaced with unverified and subjective messages of pop culture. Faced with such messages man who is not rooted in faith is not able to select information. It can be observed then that man starts to build their religious identity on the basis of what they have heard or seen in the media. Intimate religious experiences both in vertical dimension (addressed to God) and horizontal (addressed to another man) get marginalized or cease to exist completely ${ }^{13}$.

As a consequence of those phenomena, a traditional method of the transmission of values through a family and catechesis has become unsettled. Medialized reality takes the place of a real-life religious socialisation ${ }^{14}$. An excess of information also causes a problem in the life of a young person. We may state that the media „deprive every meaning of its meaning. There is no possibility of transcendence. The culture keeps spinning around more and more - everything becomes everything. By wiping out the meanings, the media deprive people of the ability to assess the world they live in. We lose this reference system which in the past was created by stable, intersubjective, verifiable notions and categories, which could be used to describe and criticize the world"15.

\section{Superficiality of relationships}

Another challenge in social communication in the context of catechesis and evangelization is an adventure style of life, which in consequence leads to superficial human relationships. Difficulty in relationships may arise from many reasons. However, modern world of media engages people so much in virtual reality that it brings about difficulty in building real communication processes between people. At present, face-to-face communication gives way to interface-to-interface communication. Social media are to blame for that. A modern model of media audience differs from a classic formula. These days people do not get satisfied only

${ }^{13}$ Cf. Tamże, s. 28; K. Skowronek, Z. Pasek (red.), Nowa duchowość w kulturze popularnej, Kraków 2013.

${ }^{14}$ Cf. J. Dobrołowicz, Mediatyzacja współczesności a procesy socjalizacji i wychowania, „Peedagogia Christiana” 34 (2014), s. 137-150.

${ }^{15}$ Z. Melosik, Kultura popularna i tożsamość młodzieży. W niewoli władzy i wolności, Kraków 2013, s. 174. 
with being the audience, but they aim at being a creator ${ }^{16}$. People want to participate actively in the communication process. The essence and the aim of functioning of social media is defined by their name - social media. This term „expresses social aims and functions of this kind of new media. Thus, they are a combination of relationships, behaviors, feelings, empiricism and user interactions where multidisciplinary communication of information, ideas and experience by means of advanced tools takes place"17. Thanks to social media, people realize their communication needs, but at the same time they lose an ability to build deeper relationships in the real world. By being a co-creator of the virtual reality, people get used to the absence of a real-life person. The feeling of anonymity fills them with courage when acting in the virtual world, but simultaneously it makes a person shy and closed in the real world. The desire and the mechanism of being online lead to the loss of touch with reality. The desire to communicate online results in losing a real, personal contact with another person. It bears the risk of cynicism and global negation ${ }^{18}$.

As a result of online contacts, ties between people are weak and superficial, deprived of stability. It should be noted that virtual communication creates the conditions for quantitative contacts as opposed to qualitative ones. They are characterized as deeply individualized and disengaged ${ }^{19}$. This superficiality acquired in virtual world translates into real world. It causes also superficiality in faith and problems with accepting the truth of faith. Faith loses its personal dimension. The authority of the Church as an institution also disappears ${ }^{20}$.

${ }^{16} \mathrm{Cf}$. A. Andrzejewska, Świat wirtualny miejscem nawiązywania i utrzymywania relacji przez młodzież, w: Edukacja - relacja - Zabawa, red. A. Wrońska, R. Lew-Starowicz, A. Rywczyńska, Warszawa 2019, s. 68-89.

${ }^{17}$ M. Chmielewski, Media społecznościowe jako narzędzie nowej ewangelizacji, „Świat i Słowo" 1(22) 2014, s. 216.

${ }^{18}$ Cf. D. Klus-Stańska, Cyfrowi tubylcy $w$ szkole cyfrowych imigrantów, czyli awatar w świecie Ptysia i Balbinki, „Problemy Wczesnej Edukacji” 9(2013) 4, s. 6-14; M. Wilkowski, Cyfrowi Tubylcy $i$ ich społeczny potencjat, w: https://www.edunews.pl/badania-i-debaty/ badania/1095-cyfrowi-tubylcy-i-ich-spoleczny-potencjal (dostęp: 16.07.2019).

${ }^{19}$ Cf. B. Kanclerz, Młodzież w rzeczywistości „globalnej zmiany” z perspektywy rówieśników, „Kultura-Społeczeństwo-Edukacja” 2 (10) 2016, s. 281-294; B. Jankowiak, Wczesna inicjacja seksualna młodzieży - przyczyny i konsekwencje, „Kultura-Społeczeństwo-Edukacja” 1 (5) 2014, s. 171-187.

${ }^{20}$ Cf. J. Kostorz, Problematyka wiary $w$ refleksji współczesnych polskich katechetyków, „Colloquia Theologica Ottoniana” 1(2014), s. 135-149; A. Żurek, Komunikacja interpersonalna 


\section{A leading role of visual communication}

Thomistic look at the order of things in the world and faith presumed theocentrism. As a result of the changes sweeping through the second half of the XX century we can speak about the dominance of anthropocentrism. Today's position of the media in the world establishes a basis to use a term mediocentrism ${ }^{21}$. The synergy of paralelly functioning and developing culture and communication has resulted in the dominance of the visual communication. The whole communication process is subject to the dominance of an image. It has happened so at the expense of a traditional message based on a word. A new anthropological situation has caused that a homo audiens has become a homo videns ${ }^{22}$. A rational and thinking person has been replaced with a looking and watching one $\mathrm{e}^{23}$.

An image starts to affect human senses not their intellect. Cultural analysis indicates a primary role of an image also in contexts neutral about religious matters ${ }^{24}$. People who put an image in the first place in a communication process very often present a diminished ability to think abstractly. It is a vital threat especially in terms of a concern for faith. Religious cognition presumes acquisition of abstract terms and symbols. Another dangerous phenomenon is a reduction of language competence. The scope of vocabulary gets limited. A language which is deprived of abstract elements becomes only a tool of communication on a basic level. Looking at a picture people give it their own interpretation without searching for the right and true one. A person with reduced abstract thinking has problems with concentration and tends to demand an immediate effect. It forms

droga do Chrześcijańskiego Braterstwa, „Studia Koszalińsko-Kołobrzeskie” 23 (2016), s. 277289; M. Rusiecki, Pedagogika w Służbie wiary, „Kieleckie Studia Teologiczne” 11 (2012), s. 161-191.

${ }^{21}$ Cf. J. Pyżalski, Agresja elektroniczna i cyberbullying jako nowe ryzykowne zachowania młodzieży, Kraków 2012, s. 16; P. Celiński, Postmedia. Cyfrowy kod i bazy danych, Lublin 2013, s. 7-11.

${ }^{22} \mathrm{Cf}$. A term homo videns comes from Italian social science. It was introduced by Giovanni Sartori in his book Homo videns. Telewizja i pomyślenie, Warszawa 2007.

${ }^{23}$ Cf. J. Iwanicki, Medializacja treści religijnych w kulturze internetowej i popularnej, „Humaniora. Czasopismo Internetowe" 18 (2017) 2, s. 22.

${ }^{24}$ Cf. S. Lubello, Loscrittofactotum dei natividigitali, „Lingue e Culture dei Media” 1 (2017), s. 143-146; A. Skudrzyk, Homo videns - nowe media a język młodego pokolenia, w: Profilaktyka logopedyczna w praktyce edukacyjnej, (red.) K. Węsierska, N. Moćkot. 2, Katowice 2013, s. 43-52. 
a significant barrier in the process of evangelization and catechesis, which is a complex and long-term processes ${ }^{25}$.

Summing up, new communication challenges give the Church ministry a difficult task. Contemporary world is not divided between sacrum and profanum areas. Both realities take part in the process of social communication. As the above-mentioned analyses show, people have a need to be accepted and to belong somewhere. Social communication fulfils many of those needs, strengthens selfesteem, allows to acquire different competencies, but at the same time it deprives people of a multitude of experiences and feelings connected with real interpersonal relationships. Man, despite having many virtual contacts, remains lonely and devoid of a deeper social and anthropological reflection. All these together challenge modern evangelization and catechesis.

\section{A PROPOSED MODEL OF EVANGELIZATION AND CATECHESIS}

In the light of the above-mentioned challenges, there arises a need for a reflection upon the concept of evangelization and catechesis. It seems that a question about the model of evangelization and catechesis is the question about the model of the Church, implicitly the Church which wants to be missionary and dynamic in ministry. Without a doubt this reflection must include a human being who lives in a specific culture and is subject to specific social and communication processes ${ }^{26}$. Presuming, in purely Thomistic categories, that the rejection of the message of the Gospel and the ministry of the Church results from a failure on the part of the preachers, every effort should be made to properly understand the essence of evangelization and catechesis ${ }^{27}$.

The latest document of the Catholic Church on the evangelization ministry is the apostolic exhortation of Pope Francis Evangelii gaudium (2013). This

${ }^{25}$ Cf. R. Gualdo, Letti disfatti. Lettura e scrittura spezzate nei quotidiani digitali, „Lingue e Culture dei Media" 2 (2018), s. 1-16; M. Tanaś, S. Galanciak, Dziecko w sieci zagrożeń - ryzykowne zachowania internetowe dzieci i młodzieży jako wyzwanie dla edukacji, w: Edukacja - relacja - Zabawa, red. A. Wrońska, R. Lew-Starowicz, A. Rywczyńska, Warszawa 2019, s. 40-61; M. Jabłońska, K. Bilewicz, Pokolenie przełomu w WEB 2.0, „Acta UniversitatisLodziensis. Folia Sociologica" 56 (2016), s. 83-97.

${ }^{26}$ Cf. M. Nardello, Evangelizzazione, Assisi 2017, s. 7-10.

${ }^{27}$ Cf. Tamże, s. 103. 
document reminds that "in catechesis... [there is] the fundamental role of the first announcement or kerygma, which needs to be the center of all evangelizing activity and all efforts at Church renewal" 28 . Thus, it can be assumed that in the face of current challenges of social communication a model of evangelization and catechesis should be based on kerygma. Pope Francis preaches that kerygma is "the fire of the Spirit is given in the form of tongues and leads us to believe in Jesus Christ who, by his death and resurrection, reveals and communicates to us the Father's infinite mercy"29. The argument speaking for kerygma is a statement that can be found in the same document: „Nothing is more solid, profound, secure, meaningful and wisdom-filled than that initial proclamation. All Christian formation consists of entering more deeply into the kerygma, which is reflected in and constantly illumines" ${ }^{\prime 30}$.

When searching for the vision of contemporary evangelization and catechesis we should start with Christ's missionary commandment: „Therefore go and make disciples of all nations, baptizing them in the name of the Father and of the Son and of the Holy Spirit, 20 and teaching them to obey everything I have commanded you. And surely, I am with you always, to the very end of the age" (Mt 28,19-20). These words cover the whole program. They command to work with the people in the community of the Church. That is exactly what the catechesis, which wants to deepen the relationship of the believers receiving sacraments with God, assumes. The words of commandment of Christ underline a missionary and dynamic character of the Church. She must evolve. Regardless of the setbacks that come in the way and in order to stay faithful to Christ, the Church must seek for new believers and bring the lost to the community of the Church. New evangelization must proceed this way. The Church must not close herself within small groups, indifferent towards the needs of the world and the lost, also or even primarily in the cyber world ${ }^{31}$.

${ }^{28}$ EG 164. To broaden the issue: Cf. P. Mąkosa (red.), Nowa ewangelizacja w nowej katechezie, Rzeszów 2013.

${ }^{29}$ EG 164; Cf. P. Mąkosa, Ewangelizacyjny wymiar katechezy, w: Katecheza w swoich podstawowych wymiarach, red. J. Czerkawski, Kielce 2013, s. 169-178.

${ }^{30}$ EG 165; Cf. P. Mąkosa, Dynamika ewangelizacji według adhortacji apostolskiej "Evangelii gaudium” papieża Franciszka, „Studia Pastoralne” 10 (2014) 10, s. 327-340.

${ }^{31}$ Cf. P. Mąkosa, Przyszłość ewangelizacji i katechezy wobec przemian kulturowych, w: Wychowanie i katecheza w służbie Polakom w kraju i na emigracji, red. P. Mąkosa, Lublin 2018, 
The proposed action requires from the whole community of the Church, and primarily from those who actively create evangelization and catechesis, a pastoral conversion ${ }^{32}$. The Church, by her nature, is of missionary character and she should make an effort to evangelize even if it calls for a change of mentality and costs a lot in spiritual and material scope. It is not only about ministry ad gentes. The toughest task is to evangelize the already baptized. It is a difficult challenge to convert the baptized and bring them into real contact with God. It is the aim and the task of new evangelization ${ }^{33}$.

Contemporary man is lost between cyberspace and search of a real relationship. Perhaps difficult conditions in which a modern society exists force the Church to organize the ministry, which might be called preevangelization. Its objective is to evoke a reflection on your own fate and looking for happiness. Preevangelization is to sensitize people towards spiritual values and help overcome reluctance to religious reality ${ }^{34}$. Only when people open up and start asking existential questions, is it possible to move on to the next stage, which is evangelization. The aim of it is to show God who is love and who loves people. As a result, people want to respond to that love and make an effort to convert. Then they proclaim Jesus as their Lord and Saviour, whom they want to follow ${ }^{35}$. If this stage is successful, we can move on to catechesis, which introduces people into the fullness of Christian life. Actually, it is only the catechesis that assumes permanent formation in the community of the Church, which leads to a deepening of the faith and strengthening of a personal relationship with $\mathrm{God}^{36}$.

Justifying the search of the right model in catechesis and evangelization, it should be noted that recognizing and receiving kerygma might be a way to bring back joy, sense of life and activity to the modern man. The words of Pope Francis who says: „The joy of the gospel fills the hearts and lives of all who encounter Jesus. Those who accept his offer of salvation are set free from sin, sorrow,

s. 8-19; M. Kałużyńska-Tyburska, Nowe media w komunikacji Kościoła ze światem, „Warszawskie Studia Pastoralne" 12 (2017), s. 119-132.

${ }^{32}$ Cf. EG 30.

${ }^{33}$ Cf. L. Luppi, La teologiadell'evangelizzazione a bolognanelquadrodella teologia post-conciliare, w: Unpensieroapertosull'evangelizazione, M. Marcheselli (red.), Bologna 2019, s. 42-43.

${ }^{34}$ Cf. S. Dyk, Nowa ewangelizacja. Konkretne wezwanie, Gubin 2015, s. 82.

${ }^{35} \mathrm{Cf}$. Tamże.

${ }^{36}$ Cf. J.L. Moral, Cittadini nella Chiesa, Cristiani nel mondo, Roma 2017, s. 166. 
inner emptiness and loneliness" ${ }^{37}$, should be regarded as crucial. These words express what the tradition of the Church called kerygma. Kerygma is not only the fundamental truth of the Gospel about God's love to mankind revealed in the Passion, death and resurrection of Jesus Christ, but also „an event of power which makes the sad, the rejected, the poor, the enslaved, the sick, the dead, the lepers and the possessed open up to a completely new reality of change - they recover themselves" 38 . The people who are poor, enslaved and lost in modern world are those who are lost in what poses threats to social communication.

The power of kerygma in the presence of media character of religiousness, superficiality of relationships and dominance of a visual message lies in the simplicity of its message. Kerygma is a message. It is not a teaching or a philosophical or theological doctrine that might raise objections. It is an event that is meant to inspire, bring about ecstasy, give food for thought and change life. An advantage of kerygma is that the whole event (message) invites people to participate in God's love. Leading to love, showing love, pointing at loving God, human kindness - all these might happen to be a bridge between God's grace and lost contemporary people. Evangelization based on kerygma assumes that people start to build a personal relationship with God through the experience of human goodness and love. It is a role of catechesis to strengthen this relationship. A citizen of modern world longs for what is real and personal. Thus, underlining kerygma in the new evangelization and catechesis ministry might be a prescription for setbacks ${ }^{39}$.

\section{NEW IDEAS}

The proposed concept for new evangelization and catechesis cannot be limited to general assumptions. It calls for concrete guidelines and ideas. Listing the most essential ones we can speak about first of all, the right order of pastoral practice which assumes catechesis preceded by evangelization; secondly, the need to give hope based on a positive message, and thirdly, the right attitude of preachers and religion teachers.

${ }^{37}$ EG 1.

${ }^{38}$ P. Spyra, Kerygmat Jezusa - Dobra Nowina o człowieku i dla człowieka, „Rocznik Teologii Katolickiej”, 13(2014) 1, s. 222. s. 221-240.

${ }^{39}$ Cf. D. Rey, Parafio obudź się. Wyzwania nowej ewangelizacji, Gubin 2014, s. 134-137. 


\section{The right order}

In order to achieve catechetical goals, one must set the right order and structure of actions. As archbishop G. Ryś said „catechesis which is not preceded by evangelization is a waste of power and means" ${ }^{\prime 4}$. The whole catechesis process, then, should be preceded by evangelization. The modern religious education model practiced at home is of little effectiveness. There is a need for preevangelization $^{41}$. In the context of modern communication challenges, especially in terms of understanding a human being and the reality they live in, we can assume that preevangelization should evoke a need for reflection on their lives, search of the sense of life, questions about happiness. Evangelization could point at the causes of the lack of joy and happiness. It should aim at guiding people out of sinful life through God's love. The final stage of evangelization should be the acceptance of Jesus Christ as the Lord and Savior. In other words, it should aim at leading to a personal relationship with Christ. As a consequence, catechesis should take up an effort to deepen and strengthen this relationship. It takes place when people get to know the truth of the faith, step into sacramental life, learn moral values and grow in prayer. It all leads to a moment when man discovers their place in the community of the Church and takes up ministry there ${ }^{42}$.

The same scheme of proceedings should be kept in case of new evangelization. It mainly refers to people who have already been baptized and even lived in the community of the Church, but due to various circumstances they ended up on the margins of religious life. Fr. Marek Dziewiecki speaks about a lot of effort that needs to be put in this matter. It is justified in the face of "new man” living in "a new type of society" and "new culture”. New evangelization is the ability to conduct a dialogue with people, where the element of human testimony goes first before doctrine. New evangelization is about a dialogue with God which is based on the law of love. There should be a lot of patience and responsibility in acting

${ }^{40} \mathrm{KAI}$, An interview with archbishop G. Ryś, in: https://www.deon.pl/religia/duchowosc-i-wiara/zycie-i-wiara/art,4208,katecheza-ktorej-nie-poprzedza-ewangelizacja-jestmarnowaniem-sil-i-srodkow.html (access: 20.07.2019).

${ }^{41}$ Italian literature uses a term „primo annunzio”, which can be translated as the first teaching or the first preaching. Cf. Conferenza Episcopale Italiana, Incontriamo Gesú, Milano 2014, s. 63-83.

${ }^{42} \mathrm{Cf}$. E. Antonelli, Una Chiesa in ascolto in uscita. Per una nuova evangelizzazione, Milano 2018, s. 47-58. 
with a view to achieving this goal and restoring the right place of people in the community ${ }^{43}$.

The biggest hurdle is to keep the right order and resist the temptation of too hasty jump into catechesis. This process requires robust preparation. The main challenge seems to be the ability to build a relationship with another man. Modern man, immersed in digital and virtual contacts, has real difficulties in undertaking authentic relationships with others. Thus, the time of preevangelization and evangelization should be mainly used to shape the capability of building relationships. Catechesis is meant to establish and strengthen the relationship with God, who can be experienced in a sensory and visual manner. Such a relationship demands from man a solid foundation in the shape of the ability to build personal relationships ${ }^{44}$.

This way of thinking can be supported by the argumentation of the earliest Christian communities. Even persecutions did not hamper their development. Clement of Alexandria (150-215) in his Paedagogus raises the issue of the differentiation between evangelization and catechesis pointing, this way, at the significance of it. By referring to the first Epistle to the Corinthians (3, 1-3), he explains that Paul's „milk” means preaching as kerygma (the use of the Greek word kerygma), whereas the well-established faith is a "solid food” like foundation, like a fruit of catechesis (the use of the Greek word katechesis). Thus, if catechesis is to come to fruition, it needs to follow kerygma preaching. To use an analogy, we may say that if life is to grow and develop in man, it must be first begotten ${ }^{45}$. Keeping the right order guarantees a gradual development in personal and religious dimension. Man can be led to the development of faith through the conjunction of building the ability to communicate in a real and personal manner and going through preevangelization, evangelization and catechesis. These latter three (and especially new evangelization) become a „way of communication” of the Church with the modern world ${ }^{46}$.

${ }^{43}$ Cf. M. Dziewiecki, Nowa ewangelizacja - nowa komunikacja, w: https://opoka.org.pl/ biblioteka/Z/ZM/nowakomunikacja_new.html (dostęp: 20.07.2019).

${ }^{44}$ Cf. J. H. Prado Flores, Nowi Ewangelizatorzy dla nowej Ewangelizacji, Poznań 2013, s. 33-38.

${ }^{45}$ P. Spyra, Kerygmat Jezusa - Dobra Nowina o człowieku i dla człowieka, „Rocznik Teologii Katolickiej", 13(2014) 1, s. 222. s. 221-240.

${ }^{46}$ Cf. Nardello, Evangelizzazione, s. 139-143. 


\section{A positive message}

One of the most characteristic features of the Church preaching after Vatican Council II is the pursuit of the positive message. This one of the most fundamental assumptions of John XXIII, who convened the Council, is also needed in the modern model of catechesis and evangelization. God's message, based on the law of love, is to lead to a comprehensive anthropological development. People, aware of their existence, should see the world and God in the positive light: as a good, not a threat ${ }^{47}$. Deep cognition and being close to God are the ultimate goals of catechesis - they prompt people to think positive. Showing God in the light of love may teach man to perceive various life situations in a positive way, more as a challenge than a difficulty. At the stage of evangelization, then, it is vital to have the kerygma truth of God, who is Love, in the center. At the stage of catechesis, in turn, it is essential to carry on this way and focus on the attitude of faith and trust, rather than difficulties in faith. God's commandments and the whole process of moral formation should be shown as an incentive and Good News, not as a restriction. When teaching prayer, a living relationship and spontaneity should be sought for, rather than a concern for external appearance. When preparing for sacraments, the richness of the grace and the reality of "being gifted" should be underlined. Formalized attitude where a sacrament becomes only a „reward” for good and thorough preparation should be avoided. Man created in the image and likeness of God should see the Donor of life and merciful Father ${ }^{48}$.

It seems particularly essential to build a proper and positive picture of the Church which should be understood and experienced as a community, not only as an institution. New evangelization and catechesis should be a ministry that brings life to the Church, promotes good, shows the beauty of being God's child and not just focuses on the defence against the threats of the world, such as: atheism, desacralisation, economic enslavement and other ${ }^{49}$.

In 2003 John Paul II in „Ecclesia in Europa” warned against a vision of the Church and preaching which recalls „the dimming of hope"50. In 2019 pope

${ }^{47}$ Cf. Moral, Cittadini nella Chiesa, s. 186-198.

${ }^{48}$ Cf. P. Goliszek, Personalistyczny wymiar katechezy, Lublin 2017, s. 205-227.

${ }^{49}$ Cf. Jan Paweł II, Przemówienie - Prowadzić dzieło Nowej Ewangelizacji (23.03.2001), w: „L'Osservatore Romano” 22 (2001) 5, s. 30-31.

${ }^{50} \mathrm{Cf}$. EiE 7-11. 
Francis urges people „not to let themselves be robbed of hope”51. A positive message which leads to building the attitude of hope and shows the closeness of God is absolutely critical in the face of modern challenges of social communication. The modern world of media „is fascinated” with fake news. It is full of tragic messages, negative comments and examples ${ }^{52}$. God and the Church are often spoken about in a very negative, often irrational, way. People who are present in this cyberspace, or even create it themselves, need a specific antidote. It is right there that new evangelization and catechesis, based on a positive message and leading to the strengthening of hope, may show people the beauty of faith and relationship with God ${ }^{53}$.

\section{The attitude of preachers and religion teachers}

A fundamental drive to take up the ministry of a preacher and religion teacher is to fulfil a missionary commandment of Christ. Using a modern theological language of Pope Francis, we may state that a personal intimate relationship with Jesus is a must ${ }^{54}$. Therefore, the first stage of successful evangelization and catechesis should be the evangelization of the ministers. Each minister should go through the stage of evangelization and catechesis in order to be well-prepared for the ministry and testimony. What it means is that each preacher and religion teacher should receive kerygma, pass through evangelization, believe in Christ and keep taking up a continuous conversion ${ }^{55}$. A personal experience of Christ's closeness must be constantly renewed. Only then will a preacher or a religion teacher be able to serve as a credible witness ${ }^{56}$.

For it is only by knowing and experiencing God that both a preacher and a religion teacher can lead others to God. Therefore, ministers must pray and work

${ }^{51} \mathrm{CV} 15$.

${ }^{52}$ Cf. M. Dębski, Negative consequences of abusing digital media by children, in: https:// portal.librus.pl/rodzina/artykuly/negatywne-konsekwencje-naduzywania-przez-dziecimediow-cyfrowych (dostęp: 20.07.2019).

${ }^{53}$ Cf. Moral, Cittadini nella Chiesa, s. 186; Conferenza Episcopale Italiana, Incontriamo Gesú, s. 26-29.

${ }^{54}$ Cf. EG 119-120; Conferenza Episcopale Italiana, Incontriamo Gesú, s. 111-114.

${ }^{55}$ Cf. EG 120-121; 165; 264.

${ }^{56}$ Cf. J. H. Prado Flores, Jak ewangelizować ochrzczonych, Poznań 2016, s. 155-156; A. Parisi, Cresere nella fedelta allo stile di vita del vangelo, w: La catechesis educa alla gioia evangelica, red. G. Alcamo, Milano 2014, s. 139-159. 
on themselves. They must be described as full of life joy. As Pope Francis emphasizes: a preacher „must never look like someone who has just come back from a funeral"57. If they reveal any sign of anxiety or of being lost, it questions their tie with Jesus. The very attitude of joy and happiness might be enticing enough to attract people to the Good News. Then evangelization and catechesis occur not only through words, but also through "the witness of a Christian life"58.

\section{Each minister should go through the stage of evangelization and catechesis in order to be well-prepared for the ministry and testimony. What it means is that each preacher and religion teacher should receive kerygma, pass through evangelization, believe in Christ and keep taking up a continuous conversion}

What is also important in the attitude of preachers and religion teachers, especially in the face of the listed social communication challenges, is their active and dynamic presence amongst people. It encompasses both real-life relationships and virtual ones. Modern social networking platforms or any other ways of digital thought exchange might become "the venues" with those who live in and surf this digital world. The virtual reality will never become a place to conduct evangelization or catechesis as they require a personal relationship. However, it might be a space where a dialogue will start. The beauty and richness of a personal relationship might be a fruit of that. A reasonable approach of preachers and religion teachers might guide out of "digital slavery" ${ }^{59}$ into the discovery of the beauty of faith ${ }^{60}$.

${ }^{57} \mathrm{EG} 10$.

${ }^{58} \mathrm{KKK}, 2044$. Cf. EG, 259: „A life transfigured by God's presence”.

${ }^{59}$ Cf. M. Feliksiak, Korzystanie z Internetu, Fundacja Centrum Badań Opinii Społecznej CBOS, Warszawa 2018, s. 7.

${ }^{60}$ Cf. P. Ochotny, Filozofia dialogu inspiracja dla komunikacji pastoralnej, „Warszawskie Studia Pastoralne" 12 (2017), s. 91-108. 
It seems that a deep formation of preachers and religion teachers is a practical response to all those challenges. They should get familiar with "the purpose of kerygma, its contents, form, essence, main elements and the order of preaching them. Otherwise, evangelization is at risk of being distorted through accentuating secondary contents, skipping vital ones or disturbing the right order which is strictly related to the history of salvation" ${ }^{\prime \prime}$.

\section{The virtual reality will never become a place to conduct evengelization or catechesis as they require a personal relationship. However, it might be a space where a dialogue will start.}

\section{CONCLUSION}

This article, which is an outcome of research, shows the complexity and breadth of new evangelization and catechesis in the face of modern social communication challenges. This elaboration gives only an outline of the problem and is limited to the most crucial issues. Nevertheless, it requires a synthetic summary.

A media character of religiousness, superficiality of relationships and a primary role of visual communication along with other co-related factors contribute to the context of modern social communication. It is a reality which sets a difficult goal for preaching and catechetical ministry. It is extremely hard to reach a person who is often closed in cyberspace, a person who is lonely, unfamiliar with the Good News. It requires a lot of diligence. In the face of such challenges there are certain ideas and solutions. In the first place, the ministry should be put in the right order. Catechesis must be preceded by evangelization and evangelization must be preceded by preevangelization. The whole ministry of the Church should

${ }^{61} \mathrm{P}$. Mąkosa, Kompetencje ewangelizatorów fundamentem nowej ewangelizacji, w: Nowa ewangelizacja w nowej katechezie, red. tenże, Rzeszów 2013, s. 198; J. A. Pagola, Percorsi di Evangelizzazione, Bologna 2018, s. 5-8. 
have a positive message and lead to hope. One of the most crucial elements of evangelization and catechesis processes is the ministry of preachers and religion teachers. They should be required to represent authentic faith, dynamic engagement and evangelical sensitivity.

Summing up, we can also submit a postulate for theological thought which would take up research on social and media communication in a broader and deeper manner. It is a media and communication reality that becomes a hegemon in programming the values of modern man. The media provide us with the language of modern communication and expression in the world of culture. A media character of thinking and communicating has also an impact on many forms of behaviour connected with faith.

At the end, we can refer to the principle of fidelity to God and man. It is a rule that prevails in the whole ministry of the Church. Following this principle, then, every effort should be made not to lose kerygma that expresses God, who is Love, in the course of seeking for new forms and methods. It is also vital to constantly look for effective ways of better understanding this Love and bringing It to modern man.

\section{BIBLIOGRAPHY}

\section{The teachings of the Church:}

Franciszek, Christusvivit, 2019.

ConferenzaEpiscopaleItaliana, IncontriamoGesú, Milano 2014.

Franciszek, Evangelii Gaudium, 2013.

Jan Paweł II, Ecclesia in Europa, 2003.

Jan Paweł II, Przemówienie - Prowadzić dzieło Nowej Ewangelizacji (23.03.2001), w: „L’Osservatore Romano" 22 (2001) 5, s. 30-31.

\section{Publications:}

Andrzejewska A., Świat wirtualny miejscem nawiqzywania i utrzymywania relacji przez młodzież, w: Edukacja - relacja - Zabawa, red. A. Wrońska, R. Lew-Starowicz, A. Rywczyńska, Warszawa 2019, s. 68-89.

Antonelli E., UnaChiesa in ascolto\& in uscita. Per una nuova evangelizzazione, Milano 2018. Boschini P., Dire Dio nel mondo secolarizato, w: Un pensiero apertosull'evangelizzazione, red. M. Marcheselli, Bologna, 2019, s. 115-138.

Celiński P., Postmedia. Cyfrowy kod i bazy danych, Lublin 2013.

Chmielewski M., Media społecznościowe jako narzędzie nowej ewangelizacji, „Świat i Słowo" 1(22) 2014, s. 213-229. 
Dobek-Ostrowska B., Podstawy komunikowania społecznego, Wrocław 2004.

Dobrołowicz J., Mediatyzacja współczesności a procesy socjalizacji i wychowania, „Peedagogia Christiana" 34 (2014), s. 137-150.

Dyk S., Nowa ewangelizacja. Konkretne wezwanie, Gubin 2015.

Eliade M., Sacrum a profanum: o istocie sfery religijnej, Warszawa 2011.

Feliksiak M., Korzystanie z Internetu, Fundacja Centrum Badań Opinii Społecznej CBOS, Warszawa 2018.

Filoramo G., Religione e religioni, Milano 2014.

Głodowski W., Komunikowanie interpersonalne, Warszawa 2006.

Goliszek P., Personalistyczny wymiar katechezy, Lublin 2017.

Gualdo R., Letti disfatti. Lettura e scrittura spezzate nei quotidiani digitali, „Lingue e Culture dei Media" 2 (2018), s. 1-16.

Huk T., Pedagogika medialna. Aspekty społeczne, kulturowe i edukacyjne, Kraków 2014.

Iwanicki J., Medializacja treści religijnych w kulturze internetowej i popularnej, „Humaniora. Czasopismo Internetowe" 18 (2017) 2, s. 17-28.

Jabłońska M., Bilewicz K., Pokolenie przełomu w WEB 2.0, „Acta Universitatis Lodziensis. Folia Sociologica" 56 (2016), s. 83-97.

Jankowiak B., Wczesna inicjacja seksualna młodzieży - przyczyny i konsekwencje , „KulturaSpołeczeństwo-Edukacja” 1 (5) 2014, s. 171-187.

Kałużyńska-Tyburska M., Nowe media w komunikacji Kościoła ze światem, „Warszawskie Studia Pastoralne" 12 (2017), s. 119-132.

Kanclerz B., Młodzież w rzeczywistości „globalnej zmiany” z perspektywy rówieśników, „Kultura-Społeczeństwo-Edukacja” 2 (10) 2016, s. 281-294.

Klus-Stańska D., Cyfrowi tubylcy w szkole cyfrowych imigrantów, czyli awatar $w$ świecie Ptysia i Balbinki, „Problemy Wczesnej Edukacji” 9(2013) 4, s. 6-14.

Kostorz J., Problematyka wiary $w$ refleksji współczesnych polskich katechetyków, „Colloquia TheologicaOttoniana" 1(2014), s. 135-149.

Lubello S., Lo scritto factotum deinatividigitali, "Lingue e Culture dei Media" 1 (2017), s. $143-146$.

Luppi L., La teologiadell'evangelizzazione a bologna nel Quadro della teologia post-conciliare, w: Un pensiero aperto sull'evangelizazione, M. Marcheselli (red.), Bologna 2019, s. $42-43$.

Mariański J., Religia i religijność w zsekularyzowanych społeczeństwach, „Zeszyty Naukowe KUL" 59 (2016) 4, s. 3-26.

Mąkosa P. (red.), Nowa ewangelizacja w nowej katechezie, Rzeszów 2013.

Mąkosa P., Dynamika ewangelizacji według adhortacji apostolskiej "Evangelii gaudium" papieża Franciszka, „Studia Pastoralne” 10 (2014) 10, s. 327-340.

Mąkosa P., Ewangelizacyjny wymiar katechezy, w: Katecheza w swoich podstawowych wymiarach, red. J. Czerkawski, Kielce 2013, s. 169-178.

Mąkosa P., Kompetencje ewangelizatorów fundamentem nowej ewangelizacji, w: Nowa ewangelizacja w nowej katechezie, red. tenże, Rzeszów 2013, s. 193-202. 
Mąkosa P., Przyszłość ewangelizacji i katechezy wobec przemian kulturowych, w: Wychowanie i katecheza $w$ służbie Polakom $w$ kraju i na emigracji, red. P. Mąkosa, Lublin 2018, s. 8-19.

Melosik Z., Kultura popularna i tożsamość młodzieży. W niewoli władzy i wolności, Kraków 2013.

Meneghetti C., Elementi della teologia della comuniczione, Padova 2015.

Moral J. L., Modernità e cambio epocale. Prospettive culturali e teologiche contemporanee, Roma 2019.

Moral J.L., Cittadininella Chiesa, Cristiani nelmondo, Roma 2017.

Nardello M., Evangelizzazione, Assisi 2017.

Nikolajew J., Jak usprawnić komunikację w przestrzeni społecznej, „Master of Business Administration" 1/2011 (116), s. 43-53.

Ochotny P., Filozofia dialogu inspiracja dla komunikacji pastoralnej, „Warszawskie Studia Pastoralne" 12 (2017), s. 91-108.

Pagola J. A., Percorsi di Evangelizzazione, Bologna 2018.

Parisi A., Cresere nella fedelta allo stile di vita del vangelo, w: La catechesis educa alla gioiaevangelica, red. G. Alcamo, Milano 2014, s. 139-159.

Prado Flores J. H., Jak ewangelizować ochrzczonych, Poznań 2016.

Prado Flores J. H., Nowi Ewangelizatorzy dla nowej Ewangelizacji, Poznań 2013.

Przybyłowski J., Komunikacja pastoralna, „Warszawskie Studia Pastoralne” 12 (2017), s. 7-27.

Pyżalski J., Agresja elektroniczna i cyberbullying jako nowe ryzykowne zachowania młodzieży, Kraków 2012.

Rey D., Parafio obudź się. Wyzwania nowej ewangelizacji, Gubin 2014, s. 134-137.

Rusiecki M., Pedagogika w Służbie wiary, „Kieleckie Studia Teologiczne” 11 (2012), s. 161-191.

Sartori G., Homo videns. Telewizja i pomyślenie, Warszawa 2007.

Skowronek K., Pasek Z. (red.), Nowa duchowość w kulturze popularnej, Kraków 2013.

Skudrzyk A., Homo videns - nowe media a język młodego pokolenia, w: Profilaktyka logopedyczna w praktyce edukacyjnej, (red.) K. Węsierska, N. Moćko t. 2, Katowice 2013, s. 43-52.

Spadaro A., Cyberteologia. Chrześcijaństwo w dobie Internetu, Kraków 2013.

Spyra P., Kerygmat Jezusa - Dobra Nowina o człowieku i dla człowieka, „Rocznik Teologii Katolickiej", 13(2014) 1, s. 221-240.

Tanaś M., Galanciak S., Dziecko w sieci zagrożeń - ryzykowne zachowania internetowe dzieci i młodzieży jako wyzwanie dla edukacji, w: Edukacja - relacja - Zabawa, red.

A. Wrońska, R. Lew-Starowicz, A. Rywczyńska, Warszawa 2019, s. 40-61.

Tilmann K., Wychowanie religijne dawniej i dziś, „Colletanea Theologica” 41(1971) 2, s. 29-42.

Wieczorek B., Wokół religii mediów, „Kultura - Media- Teologia” 11(2012), s. 18-31;

Zduniak A., Duchowość w epoce mediów elektronicznych, w: Media i religia. Nowy kontekst komunikacji, red. R. Sierocki, M. Sokołowski, A. Zduniak, Toruñ 2016, s. 38-41. 
Żurek A., Komunikacja interpersonalna drogą do Chrześcijańskiego Braterstwa, „Studia Koszalińsko-Kołobrzeskie" 23 (2016), s. 277-289.

\section{The Internet}

Wilkowski M., Cyfrowi Tubylcy i ich społeczny potencjał, w: https://www.edunews.pl/badania-i-debaty/badania/1095-cyfrowi-tubylcy-i-ich-spoleczny-potencjal (dostęp: 16.07.2019).

KAI, Wywiad z abp Grzegorzem Rysiem, w: https://www.deon.pl/religia/duchowosc-i-wiara/zycie-i-wiara/art,4208,katecheza-ktorej-nie-poprzedza-ewangelizacja-jestmarnowaniem-sil-i-srodkow.html (dostęp: 20.07.2019).

Dębski M., Negatywne konsekwencje nadużywania przez dzieci mediów cyfrowych, w: https://portal.librus.pl/rodzina/artykuly/negatywne-konsekwencje-naduzywaniaprzez-dzieci-mediow-cyfrowych (dostęp: 20.07.2019).

Dziewiecki M., Nowa ewangelizacja - nowa komunikacja, w: https://opoka.org.pl/biblioteka/Z/ZM/nowakomunikacja_new.html (dostęp: 20.07.2019).

\section{Biogram}

Ks. dr Tomasz Kopiczko. A graduate of Salesian Pontifical University in Rome, currently an assistant professor in the Department of Fundamental and Material Catechetics at Theological Faculty of Cardinal Stefan Wyszynski University and a lecturer at Higher Theological Seminary in Ełk; a deputy editor in a quarterly journal "Studia Ełckie"; scientific interests: contemporary understanding of catechesis and the Church, faith communication, evangelization. Correspondence address: tkopiczko@gmail.com e-mail: tkopiczko@gmail.com, https://orcid.org/0000-0002-8000-6714 


\title{
Marcin Wrzos
}

Wydział Teologiczny, Uniwersytet im. Adama Mickiewicza w Poznaniu

\section{Apostolische Auslandsreisen von Papst Franziskus, darunter Missionsreisen, in den wichtigsten nationalen Internetportalen (Jahr 2017)}

\author{
Apostolic journeys of Pope Francis, including missionary ones, \\ in the most important national websites (2017)
}

\begin{abstract}
ZUSAMMENFASSUNG
Die Kirche bediente sich in ihrer Tätigkeit und bedient sich weiterhin nicht nur der als christlich definierten Medien. Am Anfang der

Zeitschriften, des Radios, des Fernsehens, und schließlich auch des Internets und neuer Medien. Dieses letzte Medium verdrängt recht effektiv die früher genutzten Medien und wird ein Ort für Kommunizieren von Gedanken. In den vorgenommenen Forschungen wurden die wichtigsten meinungsbildenden Portale in Polen (www.onet.pl, www.wp.pl, www.interia. pl, www.gazeta.pl, www.o2.pl i www.fakt.pl) auf Veröffentlichung von Texten betreffend vier apostolische Auslandsreisen, darunter Missionsreisen, von Papst Franziskus im Jahre 2017 analysiert. Es wurden die Anzahl, die Qualität, die Art und die Zeit der Veröffentlichungen untersucht sowie pastorale Schlussfolgerungen bezüglich der Anwesenheit der Mission, der päpstlichen Pilgerfahrten sowie der ekklesischen Tätigkeit

in führenden Internet- und Laienportalen gezogen. Auf dieser Grundlage wurden folgende Forschungshypothesen beantwortet.

Es scheint, die erste: „Die Medien in

Polen informieren sachgemäß über die Auslandspilgerreisen von Papst Franziskus (quantitativ und qualitativ)" sei unbestätigt.

Die zweite: „Die Vorbereitung
\end{abstract}

der Geistlichen zur Benutzung neuer Medien und zur Benachrichtigung über die mit der Kirche verbundenen Fragen ist sachgemäß" ist unbestätigt; und die dritte: „Die Anzahl der Informationen und die Benachrichtigungsart über die Auslandspilgerreisen ist ungenügend" sei bestätigt.

\section{SCHLÜSSELWÖRTER:}

apostolische Reisen, Papst Franziskus, neue Medien, Internet, meinungsbildende Portale, Missionen, Kirche, Jahr 2017

\section{ABSTRACT}

In its activity, the Catholic Church has used and uses the media. At the beginning, magazines, radio, television, and finally the Internet and the so-called new media were used. This latter medium quite effectively displaces previously used ones and becomes a place of communication. In the undertaken research, the most important opinion-forming websites in Poland were analyzed (www. onet.pl, www.wp.pl, www.interia.pl, www. gazeta.pl, www.o2.pl and www.fakt.pl) in terms of publishing texts on the six foreign apostolic journeys of Pope Francis, including missionary ones in 2017. The number, quality, type and time of publication were examined, 
as well as pastoral conclusions regarding the presence of papal missions and ecclesiastical activities in secular websites. On this basis, answer the following hypotheses, the first one: "Media in Poland informs about pilgrimages Pope Francis (quantitative and qualitative)" - is unconfirmed. The second one: "Spiritual preparation for using new media and inform about issues related to the Church is appropriate" - is unconfirmed; third: "The number of information and the way of informing about pilgrimages is insufficient" - confirmed.

\title{
KEYWORDS:
}

apostolic journeys, pope Francis, new media, Internet, opinion leaders, mission, Catholic Church, year 2017

\section{Podróże apostolskie oraz misyjne Papieża Franciszka w świetle publikacji najważniejszych krajowych portali informacyjnych (2017)}

\begin{abstract}
ABSTRAKT
W swojej działalności Kościół katolicki zawsze korzystał z mediów. Na początku była to prasa, radio i telewizja, a obecnie Internet oraz tzw. nowe media. W szczególności te drugie z powodzeniem wypierają bardziej tradycyjne przekazy i stają się miejscem komunikacji. W podjętych badaniach poddano analizie najbardziej opiniotwórcze strony internetowe (www.onet.pl, www.wp.pl, www.interia.pl, www.gazeta.pl, www.o2.pl oraz www.fakt.pl) w zakresie publikowania przez nie tekstów opisujących sześć podróży apostolskich Papieża Franciszka, w tym podróży misyjnych z 2017 roku. Poddano badaniu liczbę, jakość, rodzaj i czas publikacji, a także duszpasterskie komentarze publikowane na świeckich portalach internetowych związane z faktem odbytych pielgrzymek i działalnością Papieża w Kościele. Na tej podstawie autor odnosi się do postawionych w tekście tez. Pierwsza z nich: „Media w Polsce przekazują informacje na temat pielgrzymek Papieża Franciszka (w ujęciu ilościowym i jakościowym) - nie znajduje potwierdzenia. Druga: „Przygotowanie duchowe w kierunku wykorzystania nowych mediów i informowania na temat kwestii związanych z Kościołem jest właściwe” - nie znajduje potwierdzenia. Trzecia: „Ilość informacji oraz sposób informowania o pielgrzymkach są niewystarczające" - znajduje potwierdzenie.
\end{abstract}

\section{SŁOWA KLUCZOWE:}

podróże apostolskie, Papież Franciszek, nowe media, Internet, środowiska opiniotwórcze, Kościół katolicki, rok 2017

S eit Anfang der Existenz der sozialen Kommunikationsmittel weckte das Papstten aus der Lehre der Päpste oder für Details aus dem Alltag des Apostolischen Stuhls. Zweifelsohne fiel die Gipfelzeit dieses Interesses im Inland für den Pontifikat von Johannes Paul II an. Jorge Mario Bergoglio SJ (geb. am 17. Dezember 1936 in Buenos Aires) - argentinischer römisch-katholischer Geistliche wurde am 13. März 2013 zum 266. Papst. Seit Anfang an weckte sein Pontifikat Interesse 
der weltweiten und der polnischen sozialen Kommunikationsmittel. Insbesondere gilt es für die Frage der Flüchtlinge oder der Lehre betreffend die Ehe und die Lebensübertragung, den Ökumenismus oder den religionsübergreifenden Dialog. Es scheint, dass dieses Interesse am Anfang des Pontifikats größer war und das es mit der Zeit verminderte. Das Internet und insbesondere es nutzende neue Medien ${ }^{1}$, verdrängt langsam die Papierversionen der Zeitschriften, das Radio und das Fernsehen, daher wurde es ein Ort, wo viele Veröffentlichungen über den Papst platziert werden. In diesem Gebiet erfolgt derzeit, wie es scheint, der größte Fluss von Informationen, Ideen und Gedanken. Die beliebtesten publizistischen und Informationsdienste in Polen sind: www.onet.pl, www.wp.pl, www.interia.pl, www.gazeta.pl, www.o2.pl i www.fakt.pl. Es ist erwähnenswert, dass das Portal www.onet.pl die größte Lesergruppe hat, das ein Niveau von 18,2 Mio. Nutzer monatlich erreicht, was rund $60 \%$ der Internetnutzer in Polen entspricht, und das Portal www.fakt.pl die kleinste (entsprechend 4,4 Mio., d. h. 20\% der Nutzer) ${ }^{2}$. Diese Portale haben somit eine riesige meinungsbildende Rolle, die die Haltung seiner Nutzer bildet, umso mehr, dass der Anteil der christlichen und katholischen Portale am Markt der Internetmedien gering ist ${ }^{3}$.

Die Kirche bemerkt die Notwendigkeit seiner Präsenz auf diesem Gebiet und ihre Lehre ist insbesondere in den Botschaften für den Tag der sozialen

${ }^{1}$ Für die Forschungen nehmen wir eine der verfügbaren Definitionen neuer Medien annehmen, wo neue Medien sind „Techniken, Technologien sowie Institutionen, die zur Kommunikation dienen, und die digitale Verfahren zur Erfassung, Aufzeichnung und Speicherung von Daten, zur Erstellung und Übertragung von Übermittlungen nutzen sind. Neue Medien zeichnen sich durch Hypertextstruktur der Übermittlung und des Empfangs, Programmierungsmöglichkeit (Asynchronie des Sendens und des Empfangs), Interaktivität, Kumulativität, globale Reichweite und gleichzeitig Individualisierung des Zugangs aus" - E. Chudziński (Red.), Słownik wiedzy o mediach, Warszawa - Bielsko-Biała 2007, S. 45.

${ }^{2}$ Siehe: Laut der Forschungen gehören zu den meinungsbildenden Portalen, die das Lesen auf dem Niveau von ca. 6 Mio. Nutzer in Polen erreichen: www.onet.pl (18,2 Mio. Nutzer, 60\% Bereich im Internet), www.wp.pl (15,8 Mio., 47,7\%), www.interia.pl (13,9 Mio., 34,4\%), www.gazeta.pl (10,5 Mio., 26,8\%), www.o2.pl (6,91 Mio., 24,7\%) und www.fakt.pl (6,79 Mio., 24,25\%). Quelle: Megapanel PBI/Gemius, Januar 2018, Anzahl der Versuchspersonen: $\mathrm{N}=145$ 982, mit der Forschung umfasste Gruppe: 7-75 Jahre.

${ }^{3}$ Siehe: Laut dieser Forschungen waren die am häufigsten besuchten christlichen Webseiten: www.deon.pl (1,1 Mio. Nutzer, 3,95\%), www.opoka.org.pl (0,65 Mio., 2,33\%), www. wiara.pl (0,64 Mio., 2,31\%), www.niedziela.pl (0,51 Mio., 1,80\%), www.gloria.tv (0,50 Mio., 1,76\%). Quelle: Megapanel PBI/Gemius, Januar 2018, Anzahl der Versuchspersonen: N=145 982, mit der Forschung umfasste Gruppe: 7-75 Jahre. 
Kommunikationsmittel mit dem Erscheinen neuer Kommunikationskanäle verbunden. Neue Informationstechniken sind vielschichtig. Sie bilden nicht nur neue Werkzeuge für die Kirche, die zur Erfüllung ihrer Evangelisierungsmission dienen. Es ist auch der Raum, in dem die Kirche anwesend sein soll und den sie mit den Evangeliumswerten erfüllen soll. Theologen der sozialen Kommunikationsmittel weisen darauf hin, dass obwohl bis vor Kurzem „die Kirche Missionen führte und das Korn des Evangeliums vom Kontinent zum Kontinent übertrug, betritt sie um die Wende des 20. und 21. Jahrhunderts nach Geburt Christi einen ganz „neuen Boden ${ }^{4 “}$. Der erste Papst, der die besondere Bedeutung des Internets bemerkte, war Johannes Paul II. In der Botschaft zum Welttag der Massenmedien sprach er über eine „Ära der Computer“ und die Verwendung von „computerisier-

Seit Anfang der Existenz der sozialen Kommunikationsmittel weckte das Papstamt das Interesse in Polen. Die Menschen interessierten sich für Neuheiten aus der Lehre der Päpste oder für Details aus dem Alltag des Apostolischen Stuhls. Zweifelsohne fiel die Gipfelzeit dieses Interesses im Inland für den Pontifikat von Johannes Paul II an.

ten Beteiligungssystemen“, d. h. Internet, für die Umsetzung der Kirchenmission. ${ }^{5}$. Papst Benedikt XVI. nennt das Internet ein „digitales Kontinent, das zu evangelisieren ist, das jedoch auch evangelisiert ${ }^{6 \text { ", }}$ und Papst Franziskus stellt die Internetmedien als praktische Werkzeuge dar, die an der Kommunikation der

${ }^{4}$ J. Kloch, Kościół w Polsce wobec Web 2.0, Kielce 2013, S. 21.

${ }^{5}$ Siehe Johannes Paul II., Orędzie na 24. Światowy Dzień Środków Społecznego Przekazu, Misja Kościoła w erze komputerów. 24. Januar 1990.

${ }^{6}$ Siehe Benedikt XVI., Orędzie na 43. Światowy Dzień Środków Społecznego Przekazu. Nowe technologie, nowe relacje. Trzeba rozpowszechniać kulturę szacunku, dialogu i przyjaźni, 24. Januar 2009. 
Barmherzigkeit teilnehmen können ${ }^{7}$ und weist auch auf damit verbundene Probleme, insbesondere die Fake News hin $^{8}$. Sofern die christlichen Internetportale umfangreich über die ekklesische Tätigkeit informieren und sie analysieren, wurden jedoch noch keine breiteren Forschungen der Kirchenanwesenheit im Laienbereich des Internets vorgenommen.

Diese Forschung betrifft einen kleinen Abschnitt dieser Präsenz in den am meisten besuchten meinungsbildenden Portalen im Inland, die Gegenstand einer ausgefeilten Schlussfolgerung sein sollte. Es betrifft Papst Franziskus und seine apostolischen Reisen im Jahre 2017. Die vorigen Jahre des Pontifikats wurden in den früheren Forschungen analysiert ${ }^{9}$. Der Forschungsprozess besteht aus zwei Stufen: Die erste ist die Bearbeitung der im Internet veröffentlichten Artikeln mit der Methode einer quantitativ-qualitativen Analyse des Inhalts. Dann nehmen wir eine theologisch-missionswissenschaftliche Analyse der erhaltenen Daten vor und ziehen pastorale Schlussfolgerungen. Die Forschungsarbeiten teilen wir in Folgendes:

1. Inhaltsanalyse der Artikeln über die Missionsreisen von Papst Franziskus (2017) in den wichtigsten Portalen mit der quantitativ-qualitativen Methode. Die gesammelten Artikeln betreffen die folgenden Pilgerreisen:
a. 28.-29. April - Ägypten;
b. 12.-13. Mai - Portugal;
c. 6.-11. September - Kolumbien;
d. 27. November - 2. Dezember - Myanmar (Birma), Bangladesch;
2. theologische Analyse der veröffentlichten Inhalte;

3. pastorale Schlussfolgerungen und Antwort auf die Forschungshypothesen, a.) Die Medien in Polen informieren sachgemäß über die Auslandspilgerreisen

${ }^{7}$ Siehe Franziskus I., Orędzie na 50. Światowy Dzień Środków Społecznego Przekazu Komunikacja i Miłosierdzie - owocne spotkanie, 24. Januar 2016.

${ }^{8}$ Siehe Franziskus I., Orędzie na 52. Światowy Dzień Środków Społecznego Przekazu «Prawda was wyzwoli» (J 8, 32). Fake news a dziennikarstwo pokoju“ 24. Januar 2018.

${ }^{9}$ Siehe M. Wrzos, Zagraniczne podróże apostolskie, w tym misyjne, papieża Franciszka w najważniejszych krajowych portalach internetowych, cz. I (lata 2013-2014), in: „Kultura-Media-Teologia”, 1 (28) 2017, S. 111-141; Derselbe, Zagraniczne podróże apostolskie, $w$ tym misyjne, papieża Franciszka $w$ najważniejszych krajowych portalach internetowych, cz. II (rok 2015); in: „Kultura-Media-Teologia”, 4 (31) 2017, S. 140-179; Derselbe, Zagraniczne podróże apostolskie, $w$ tym misyjne, papieża Franciszka $w$ najważniejszych krajowych portalach internetowych, cz. III (rok 2016); in: „Kultura-Media-Teologia”, 31 (2019), zum Druck gesetzt. 
von Papst Franziskus (quantitativ und qualitativ); b.) Die Vorbereitung der Geistlichen zur Benutzung neuer Medien und zur Benachrichtigung über die mit der Kirche verbundenen Fragen ist sachgemäß; c.) Die Anzahl der Informationen und die Benachrichtigungsart über die Auslandspilgerreisen ist ungenügend.

\section{INHALTSANALYSE DER IN DEN WICHTIGSTEN PORTALEN VERÖFFENTLICHTEN ARTIKELN ÜBER DIE MISSIONSREISEN VON PAPST FRANZISKUS (2017) MIT DER QUANTITATIV-QUALITATIVEN METHODE}

\begin{tabular}{|l|l|}
\hline \multicolumn{2}{|l|}{ Methodologie der ersten Stufe der Forschungen } \\
\hline - Analysierte Zeit: & $\begin{array}{l}\text { a. 28. Januar 2017 - 29. Juli 2017; } \\
\text { b. 12. Februar 2017 - 13. August 2017; } \\
\text { c. 6. Juni 2017 - 11. Dezember 2017; } \\
\text { d. 27. August 2017 - 2. März 2018; } \\
\text { Drei Monate vor und drei Monate nach den päpstlichen Pilgerreisen; }\end{array}$ \\
\hline - Analysierte Dienste: & $\begin{array}{l}\text { www.onet.pl; www.wp.pl; www.interia.pl; www.gazeta.pl; www.o2.pl } \\
\text { und www.fakt.pl (meinungsbildende Portale mit dem Niveau von mind. } \\
\text { rund 6 Mio. Nutzern in Polen) }\end{array}$ \\
\hline - Inhaltsquellen: & Newspoint ${ }^{10}$ \\
\hline - Tiefe der Analyse: & $\begin{array}{l}\text { verbunden (automatisch und manuell) - in den erhaltenen Ergebnissen } \\
\text { der automatischen Suche nach den programmierten Algorithmen erfolgt } \\
\text { Selektion der Wahlrichtigkeit durch den Forscher. }\end{array}$ \\
\hline - Sprache der Quellen: & Polnisch \\
\hline - Sprache der Suche: & Polnisch \\
\hline - Filtern von Spam/ & $\begin{array}{l}\text { verbunden (automatisch und manuell) - in den erhaltenen Ergebnissen } \\
\text { der automatischen Suche nach den programmierten Algorithmen erfolgt } \\
\text { Selektion der Wahlrichtigkeit durch den Forscher. }\end{array}$ \\
\hline
\end{tabular}

${ }^{10}$ Newspoint ist ein das Internet überwachender Dienst, am meisten kommerziell, für Werbeauftraggeber sowie Träger, die ein Gewerbe im Internet betreiben. Es ist ein EDVSystem zur Überwachung des Internets, der sozialen und traditionellen Medien. Es führte Analysen mit quantitativ-qualitativen Methoden, u. a. Inhaltsanalyse, CAWI, FGI, IDI durch. Es überwacht Internetdienste, Internetportale, Blogs, Foren, soziale Dienste (z. B. Faceboook), Mikroblogs (z. B. Twitter) und andere Dienste. Es wird zu Internetforschungen und zu Forschungen über Internetnutzer verwendet. Newspoint gehört zur Internationalen Vereinigung für Messung und Auswertung der Kommunikation (Association for Measurement and Evaluation of Communication, AMEC), die die Qualität der durchgeführten Analysen zertifiziert. 


\begin{tabular}{|c|c|}
\hline • Schlüsselfragen/-wörter: & 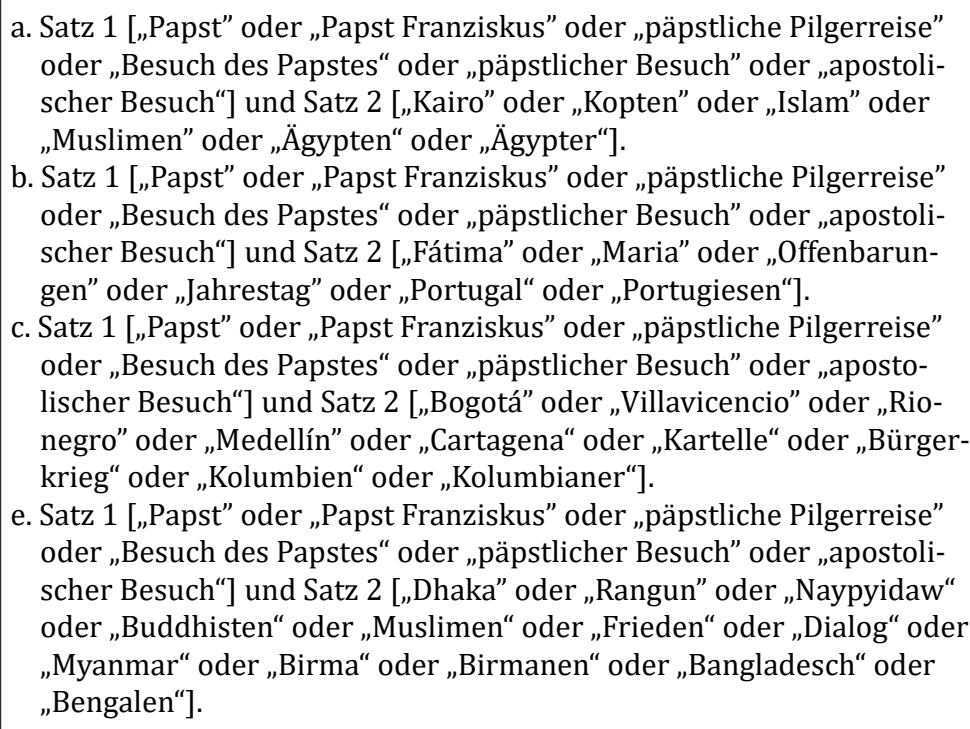 \\
\hline - Analyseeinheit: & $\begin{array}{l}\text { beliebiges Wort aus Satz } 1 \text { zzg. beliebiges Wort als Satz 2, in beliebiger } \\
\text { Sprachversion; }\end{array}$ \\
\hline $\begin{array}{l}\text { - Anzahl der analysierten } \\
\text { Artikeln: }\end{array}$ & $\begin{array}{l}\text { a. } 24 ; \\
\text { b. } 14 ; \\
\text { c. } 29 ; \\
\text { d. } 17 ; \Sigma=84 \text {. }\end{array}$ \\
\hline
\end{tabular}

\subsection{8.-29. April - Ägypten}

Die 18. Auslandsreise von Papst Franziskus fand vom 28. bis zum 29. April 2017 statt und es verlief unter dem Motto „Papst des Friedens in Ägypten der Friedens“. Der Papst begab sich nach Ägypten (Kairo, der Hauptstadt) auf Einladung von Präsidenten Abd al-Fattah as-Sisi, der Bischöfe der katholischen Kirche in Ägypten, des Patriarchen der koptisch-orthodoxen Kirche Tawardos II. sowie des großen Imams der Moschee Al-Azhar in Kairo Ahmad al-Tayyeb. Franziskus war der zweite Papst, der Ägypten besuchte. Früher war Johannes Paul II im Jahre 2000 in diesem Lande anwesend.

In den analysierten Portalen wurden 24 Texte zu diesem Thema veröffentlicht. Der erste war die Nachricht vom 18. März 2017 im Portal www.onet.pl. Es war eine lakonische Pressenankündigung des geplanten Besuchs von Papst Franziskus in Ägypten. Es wurde darauf hingewiesen, dass der Besuch auf Einladung nicht nur der Staats- oder katholischen Behörden, sondern auch des Vorstehers 
der Kopten und der Muslimen stattfindet ${ }^{11}$. Die letzte Veröffentlichung erschien am 30. April 2017 im Portal www.wp.pl und es war eine Zusammenfassung der endenden Pilgerreise. Es war eine Aufzeichnung der Pressekonferenz im päpstlichen Flugzeug. Außer der Bilanz der Pilgerreise nach Ägypten sagte Papst Franziskus den Journalisten, dass Europa aufgrund unterschiedlicher Probleme, darunter Populismus und Kultur der Verschlossenheit mit Spaltung gefährdet ist. Er appellierte auch um Verhandlungen und diplomatische Lösung der Krise um Nordkorea $^{12}$. Die mit der Pilgerreise verbundenen Berichte wurden während ihrer Dauer veröffentlicht. Es waren am häufigsten Pressemitteilungen bzw. ihre

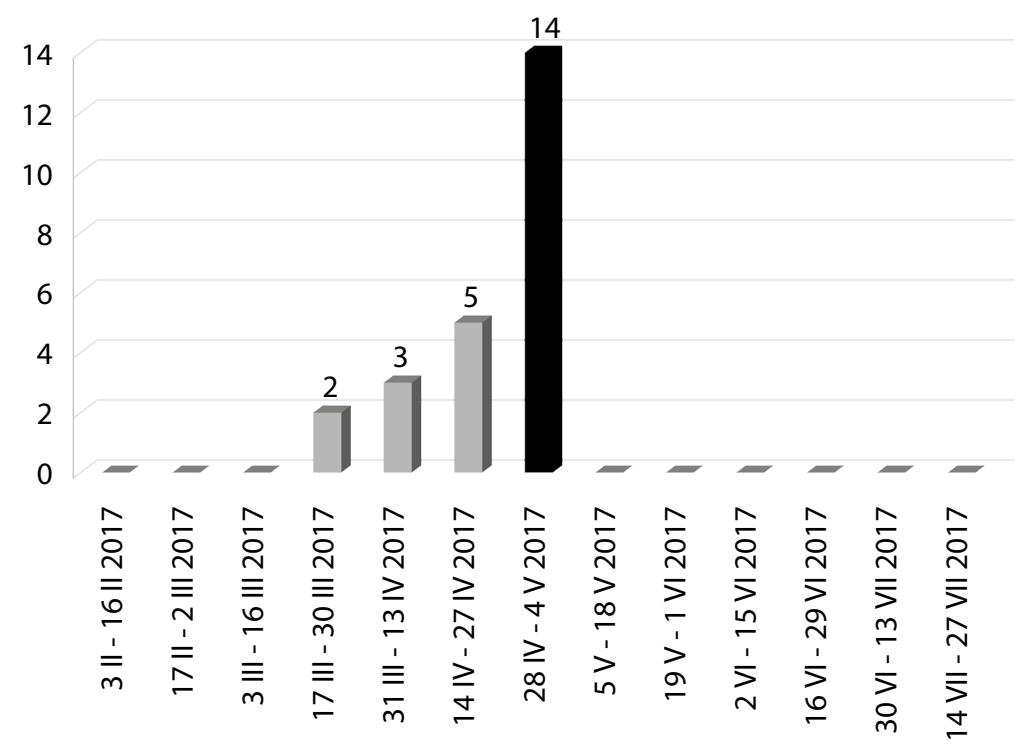

Diagramm Nr. 1. Anzahl der Publikationen zum Thema des Besuchs von Papst Franziskus in Ägypten in den polnischen Portalen nach dem Veröffentlichungstag, $\mathrm{N}=24$

Quelle: Newspoint

${ }^{11}$ Siehe [ohne Autor], Watykan: papież Franciszek w kwietniu odwiedzi Egipt, 18.03.2017, in: http://wiadomosci.onet.pl/swiat/watykan-papiez-franciszek-w-kwietniu-odwiedziegipt/5bhqwyx, [Zugriff 15.03.2018].

${ }^{12}$ Siehe [ohne Autor], Papież o groźbie rozpadu Europy i kryzysie wokół Korei Północnej, 30.04.2017, in: http://wiadomosci.wp.pl/papiez-o-grozbie-rozpadu-europy-i-kryzysie-wokol-korei-polnocnej-6117409480517249a, [Zugriff 25.03.2018]. 
Kommentare (20). Es gab 10 veröffentlichte Nachrichten in der Zeit vor der päpstlichen apostolischen Reise und 6 danach. Die letzte davon wurde ein Tag nach ihrer Beendigung veröffentlicht.

Die meisten Nachrichten zum Thema der päpstlichen Pilgerreise nach Ägypten veröffentlichte das Portal www.interia.pl (11), was ihm rund 46\% des Anteils am Markt der Internetnachrichten zu diesem Thema ausmacht. Die weiteren Portale unter Berücksichtigung der Publikationsanzahl waren entsprechend: www. onet.pl (8), www.wp.pl (4) und www.fakt.pl (1). Keine Informationen zum analysierten Thema veröffentlichten www.gazeta.pl (0) und www.o2.pl (0). Im Falle

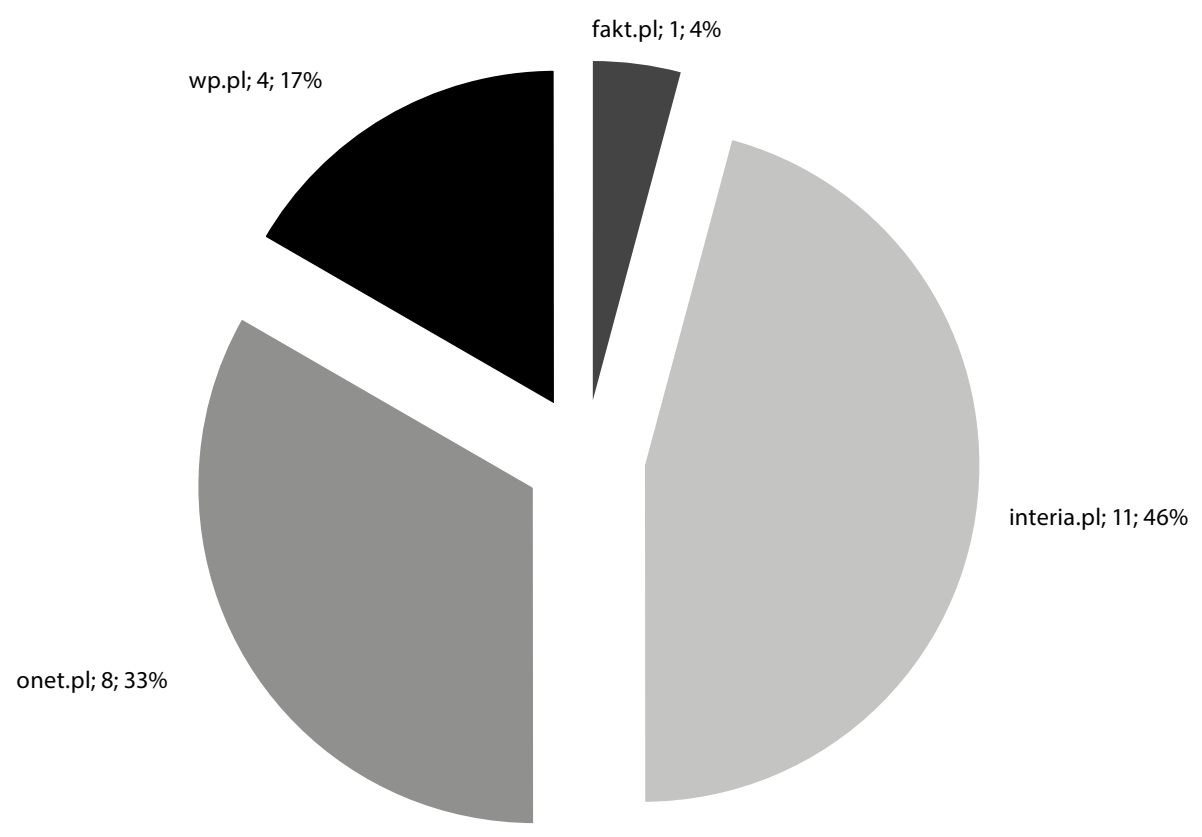

Diagramm Nr. 2. Anzahl der Publikationen zum Thema des Besuchs von Papst Franziskus in Ägypten in den polnischen Portalen nach dem Veröffentlichungsort, N=24 Quelle: Newspoint

des Portals www.gazeta.pl erschienen einzelne Nachrichten während der Pilgerreise. Derzeit sind sie nicht mehr im Portal verfügbar.

Weitere Stufe der auszuführenden Forschungen war Ermittlung der Kommunikationsweise über diese apostolische Pilgerreise von Papst Franziskus. Aus 
den durchgeführten Forschungen geht es hervor, dass 24/24 der veröffentlichten Nachrichten positiv (1) bzw. neutral waren (23). Es gab keine negativen Kommentare. Es hängt unter anderem damit zusammen, dass es sich bei den meisten Publikationen um Agenturmitteilungen von Informationsnatur handelt.

Das Zahlenverhältnis der positiven und negativen zum Thema der besprochenen Pilgerreise veröffentlichten Nachrichten ist aufgrund dessen, dass es lediglich neutrale Nachrichten waren, identisch.

Die meisten geforschten Internetportale bedienen sich der Mitteilungen der Polnischen Nachrichtenagentur (PAP), der Katholischen Informationsagentur (KAI), der Rundfunkinformationsagentur (RAI) und von Radio Vatikan (RV). Die

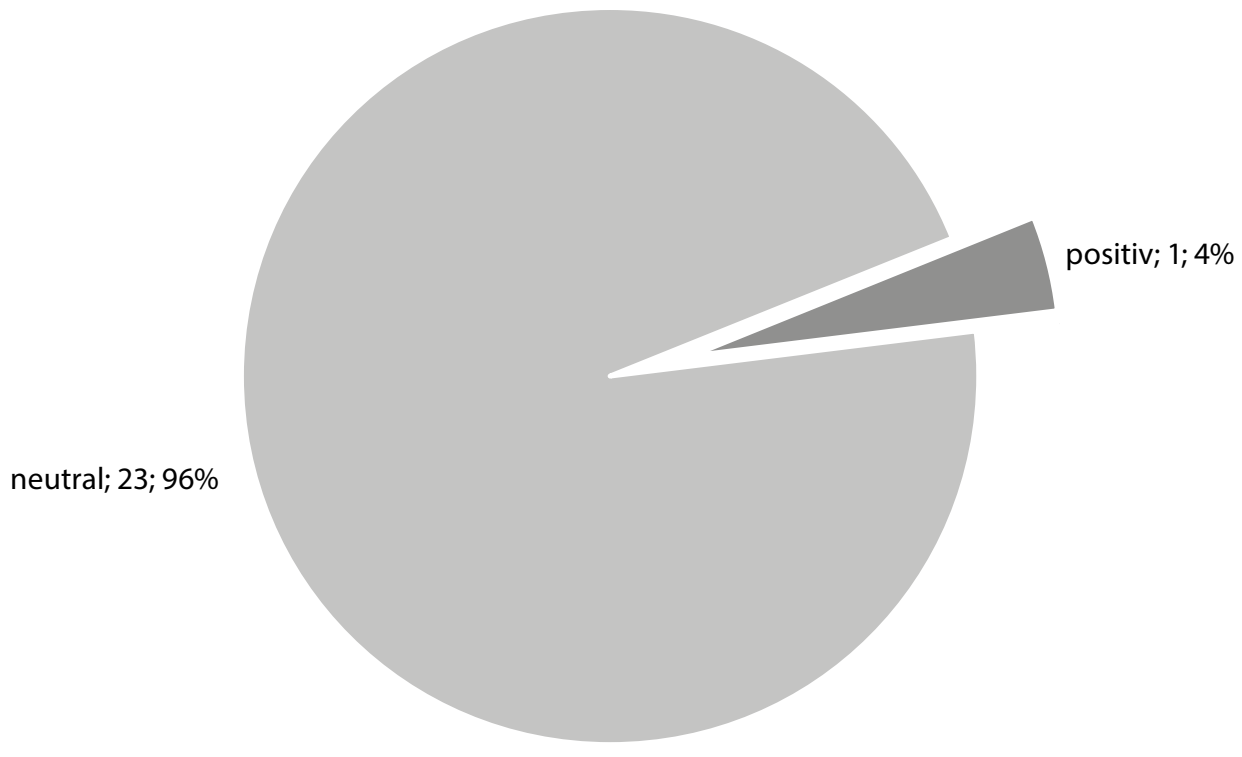

Diagramm Nr. 3. Anzahl der Publikationen zum Thema des Besuchs von Papst Franziskus in Ägypten in den polnischen Portalen nach der Veröffentlichungsart, N=24 Quelle: Newspoint

Aussage der Nachrichten war somit neutral. Es gab keine negativen. Es wurden keine Materialien veröffentlicht, die die Aussage und den Inhalt der päpstlichen Reden vertieften, die letzten davon waren Nachrichten aus der Rückkehr des Papstes nach Rom und mit der Friedensgefährdung in Nordkorea verbunden. Sie 


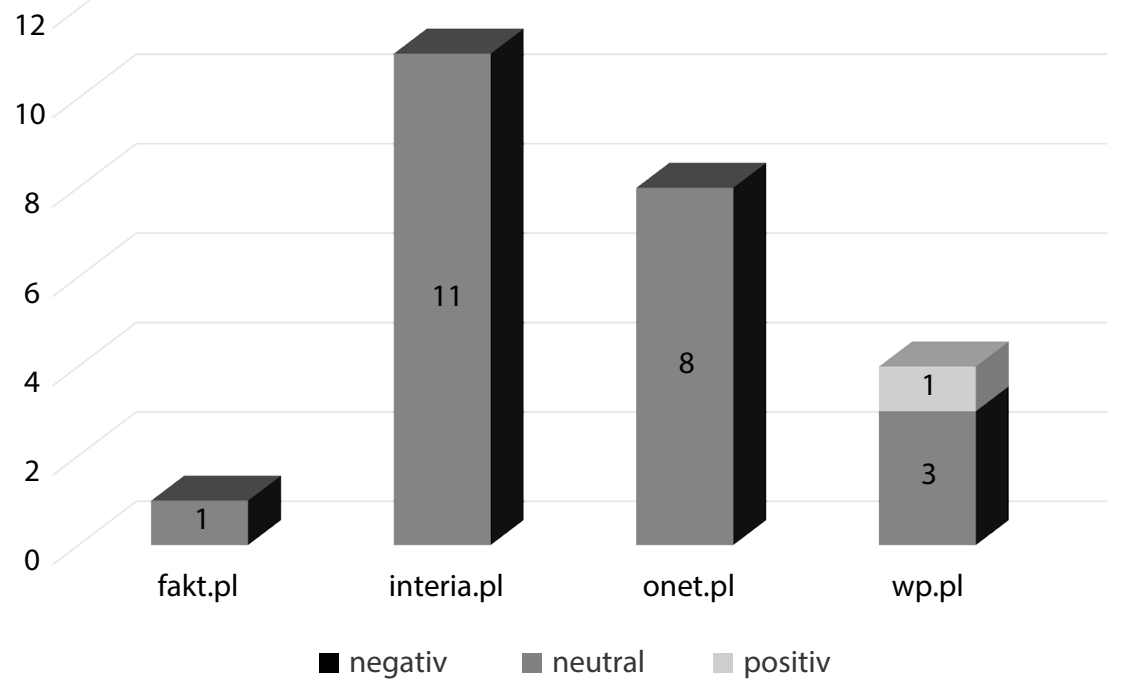

Diagramm Nr. 4. Anzahl der Publikationen zum Thema des Besuchs von Papst Franziskus in Ägypten in den polnischen Portalen nach dem Veröffentlichungsort und -art, $\mathrm{N}=24$

Quelle: Newspoint

informierten auch über den Appel des Papstes, alle Länder, darunter Russland, in die Friedensprozesse einzuschließen ${ }^{13}$. Während der Pilgerreise konzentrierten sich die Publizisten auf die Äußerungen des Papstes bezüglich des Extremismus. Der Papst sprach darüber, dass das Christentum mit dem Radikalismus der Liebe zusammenhängt. In den Artikeln wurde die Angst ums Leben des Papstes aufgrund der angesagten Attentate betont ${ }^{14}$.

${ }^{13}$ Siehe [ohne Autor], Papież o groźbie rozpadu Europy i kryzysie wokół Korei Północnej, 30.04.2017, in: http://wiadomosci.wp.pl/papiez-o-grozbie-rozpadu-europy-i-kryzysiewokol-korei-polnocnej-6117409480517249a, [Zugriff 25.03.2018]; [ohne Autor], Papież apeluje ws. kryzysu wokół Korei Północnej, 30.04.2017, in: http://wiadomosci.onet.pl/swiat/ papiez-apeluje-ws-kryzysu-wokol-korei-polnocnej/wv81480, [Zugriff 25.03.2018]; [ohne Autor], Papież: to dobrze, że Rosja mówi o obronie chrześcijan, 30.04.2017, in: http://wiadomosci.onet.pl/swiat/papiez-to-dobrze-ze-rosja-mowi-o-obronie-chrzescijan/hdqpy4t, [Zugriff 25.03.2018]

${ }^{14}$ Siehe [ohne Autor], Papież w Egipcie. Zaostrzone środki bezpieczeństwa 27.04.2017, in: http://fakty.interia.pl/raporty/raport-nowy-papiez/aktualnosci/news-papiez-w-egipciezaostrzone-srodki-bezpieczenstwa,nId,2387298, [Zugriff 25.03.2018]; [ohne Autor], $P a-$ pież: Została okrutnie przelana krew bezbronnych, 28.04.2017, in: http://fakty.interia.pl/ 


\subsection{2.-13. Mai - Portugal}

Die apostolische Reise von Papst Franziskus nach Portugal fand vom 12. bis zum 13. Mai 2017 statt und verlief unter dem Motto „Mit Maria, ein Pilger der Hoffnung und des Friedens“. Es war eine Nichtmissionspilgerreise des Papstes im analysierten Jahr. Dieser Besuch hatte zum Ziel, des hundertsten Jahrestages der ersten Offenbarungen von Gottesmutter an drei Hirten: Jacinta and Francisco Marto sowie Lucia dos Santos am 13. Mai 1917 zu gedenken. Einer der Punkte dieser Reise war die feierliche Heiligsprechung von Francisco und Jacinta Marto. Franziskus war vierter Bischof von Rom, der das portugiesische Heiligtum besuchte und zweiter der nur Fátima besuchte. Zu diesem Heiligtum pilgerten: Paul VI. (am 50. Jahrestag der Offenbarungen am 13 Mai 1967), Johannes Paul II. (1982, 1991 und 2000) sowie Benedikt XVI. (2010).

In den analysierten Portalen wurden 14 Texte zum Thema dieses Besuchs veröffentlicht. Der erste war die Nachricht vom 30. März 2017 im Portal www. interia.pl. Es war eine Ankündigung der geplanten Pilgerreise nach Fátima und auch Informationen betreffend die Logistik- und Schutzmaßnahmen, um den Pilgern Sicherheit zu gewährleisten, deren Zahl auf 5 Mio. geschätzt wurde ${ }^{15}$. Die letzte Publikation erschien am 13. Mai 2017 im Portal www.onet.pl. Die Publizisten kommentierten die päpstliche Pilgerreise im Zusammenhang mit den Feierlichkeiten des Jubiläums der Offenbarungen von Fátima im Lande ${ }^{16}$. Die mit der Pilgerreise verbundenen Berichte erschienen spätestens am Tag der Pilgerreise. Es wurden am häufigsten Pressemitteilungen veröffentlicht (12). Es wurden 4

swiat/news-papiez-zostala-okrutnie-przelana-krew-bezbronnych,nId,2388441, [Zugriff 25.03.2018]; [ohne Autor], Franciszek w Egipcie: jedyny dopuszczalny ekstremizm to radykalizm miłości, 29.04.2017, in: http://fakty.interia.pl/religia/news-papiez-jedyny-dopuszczalnyekstremizm-to-radykalizm-milosci,nId,2388479, [Zugriff 25.03.2018]; [ohne Autor], Papież Franciszek zakończył wizytę w Egipcie, 29.04.2017, in: http://fakty.interia.pl/galerie/swiat/ zdjecie,iId,2303100,iAId,248650, [Zugriff 25.03.2018]; [ohne Autor], Franciszek w Egipcie: jedyny dopuszczalny ekstremizm to radykalizm miłości, 29.04.2017, in: http://wiadomosci.onet.pl/swiat/franciszek-w-egipcie-jedyny-dopuszczalny-ekstremizm-to-radykalizmmilosci/7ltsk23, [Zugriff 25.03.2018].

${ }^{15}$ Siehe [ohne Autor], Portugalia przywróci kontrole na granicach $w$ związku z wizyta papieża, 30.03.2017, in: http://fakty.interia.pl/swiat/news-portugalia-przywroci-kontrole-nagranicach-w-zwiazku-z-wizyt,nId,2375821, [Zugriff 25.03.2018].

${ }^{16}$ Siehe [ohne Autor], Ciechanów: jubileusz 100-lecia objawień fatimskich. Uroczysta msza, 13.05.2017, in: http://warszawa.onet.pl/ciechanow-jubileusz-100-lecia-objawienfatimskich-uroczysta-msza/b4bz788, [Zugriff 15.03.2018]. 


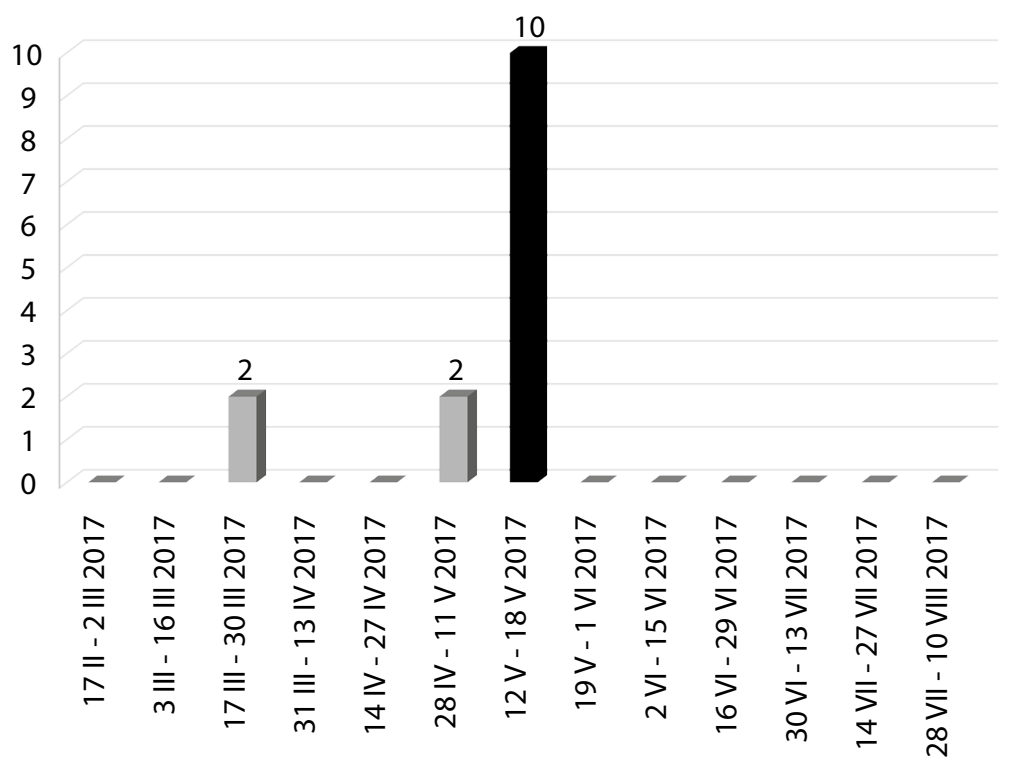

Diagramm Nr. 5. Anzahl der Publikationen zum Thema des Besuchs von Papst Franziskus in Portugal in den polnischen Portalen nach dem Veröffentlichungstag, $\mathrm{N}=14$

Quelle: Newspoint

Nachrichten vor der päpstlichen apostolischen Reise und keine (0) danach veröffentlicht. Die letzten mit der Pilgerreise nach Portugal verbundenen Nachrichten erschienen an ihrem letzten Tag.

Die meisten Nachrichten zum Thema der päpstlichen Pilgerreise nach Portugal veröffentlichte das Portal www.onet.pl (7), was ihm rund 50\% des Anteils am Markt der Internetnachrichten ausmacht. Die weiteren Portale unter Berücksichtigung der Publikationsanzahl waren entsprechend: www.interia.pl (5) und www.o2.pl (2). Die übrigen Internetportale benachrichtigten darüber nicht, somit: www.gazeta.pl (0), www.wp.pl (0) und www.fakt.pl (0). Im Portal www.gazeta.pl erschienen einzelne Nachrichten während der Pilgerreise. Derzeit sind sie nicht mehr im Portal verfügbar.

Weitere Stufe der auszuführenden Forschungen war Ermittlung der Kommunikationsweise über diese apostolische Pilgerreise von Papst Franziskus. Aus den durchgeführten Forschungen geht es hervor, dass 8/9 der veröffentlichten Nachrichten positiv (4) bzw. neutral waren (29). Es gab 2 negative Kommentare. Die negativen Kommentare betrafen die Furcht vor Immigranten und der Reaktion auf die Entscheidung des Papstes, Migranten nach Rom hinzubringen. 


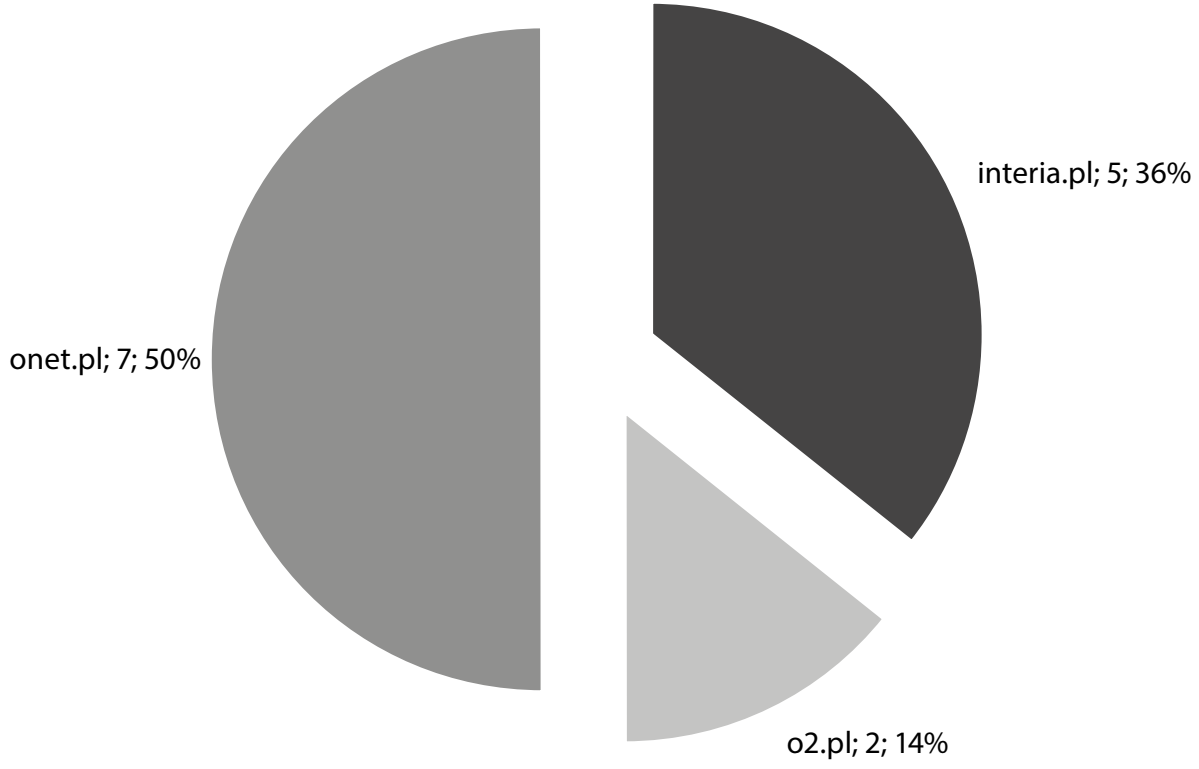

Diagramm Nr. 6. Anzahl der Publikationen zum Thema des Besuchs von Papst Franziskus in Portugal in den polnischen Portalen nach dem Veröffentlichungsort, $N=14$ Quelle: Newspoint

neutral; $12 ; 86 \%$

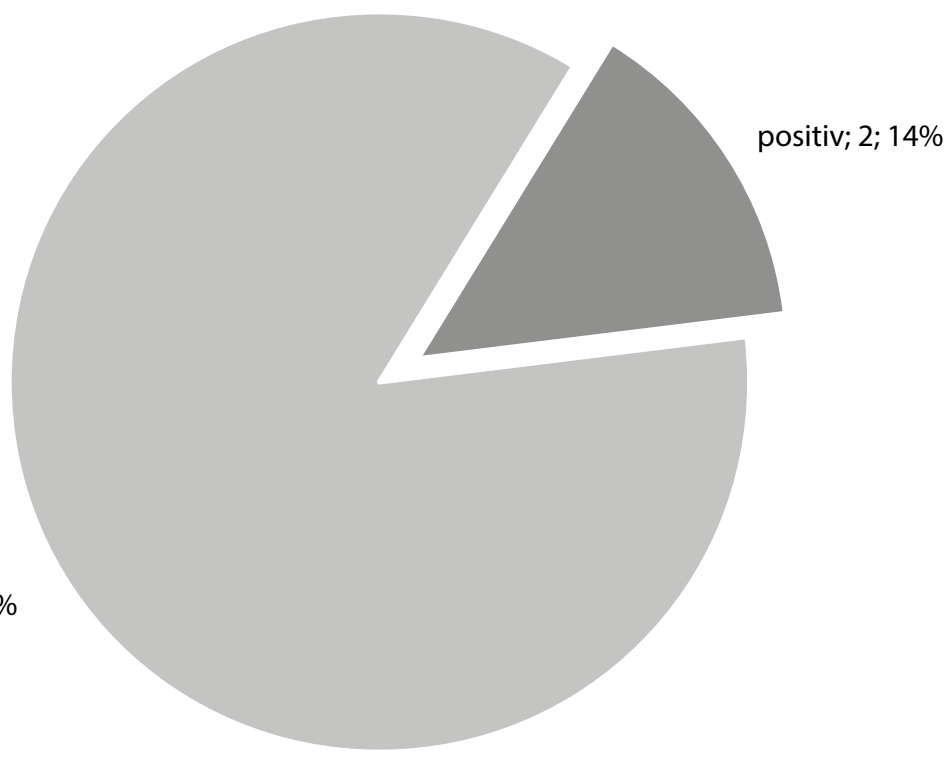

Diagramm Nr. 7. Anzahl der Publikationen zum Thema des Besuchs von Papst Franziskus in Portugal in den polnischen Portalen nach der Veröffentlichungsart, $\mathrm{N}=14$ Quelle: Newspoint 
Das Zahlenverhältnis der positiven und negativen zum Thema der besprochenen Pilgerreise Nachrichten ist aufgrund dessen, dass es lediglich neutrale bzw. positive Nachrichten waren, identisch.

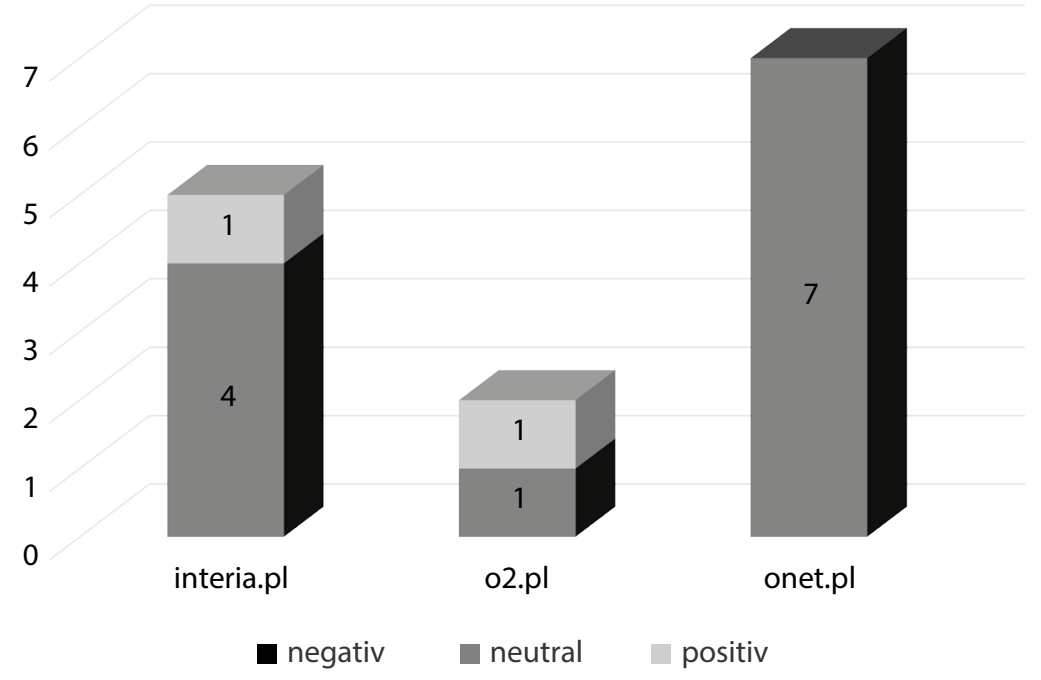

Diagramm Nr. 8. Anzahl der Publikationen zum Thema des Besuchs von Papst Franziskus in Portugal in den polnischen Portalen nach dem Veröffentlichungsort und -art, $\mathrm{N}=14$

Quelle: Newspoint

Die meisten geforschten Internetportale bedienen sich der Mitteilungen aus den Diensten PAP, KAI, RAI und RV. Die Aussage der Nachrichten war somit neutral, ohne Angabe des Autors. Es gab keine negativen Nachrichten oder Kommentare. Materialien, die die Aussage und den Inhalt der päpstlichen Reden vertieften, wurden nicht veröffentlicht. Die letzten davon waren Nachrichten über die Rückkehr des Papstes nach Rom ${ }^{17}$. Während der Pilgerreise konzentrierten sich die Publizisten auf die Äußerungen des Papstes bezüglich des Extremismus,

${ }^{17}$ Siehe [ohne Autor], Franciszek ogłosił świętymi pastuszków z Fatimy. Za ich wstawiennictwem cudem ocalało dziecko, 13.05.2017, in: http://wiadomosci.onet.pl/swiat/franciszek-oglosi-swietymi-pastuszkow-z-fatimy-za-ich-wstawiennictwem-cudem-ocalalo/rv2pm21, [Zugriff 25.03.2018]; [ohne Autor], 500 tys. osób na mszy w Fatimie, 13.05.2017, in: http:// wiadomosci.onet.pl/swiat/500-tys-osob-na-mszy-w-fatimie/ejlr8q4, [Zugriff 25.03.2018]. 
in den er darauf hinwies, dass das Christentum mit dem Radikalismus der Liebe zusammenhängt. In den Artikeln wurde die Angst ums Leben des Papstes aufgrund der angesagten Attentate betont ${ }^{18}$.

\subsection{6.-11. September - Kolumbien}

Die dritte analysierte apostolische Reise von Papst Franziskus, deren Ziel Kolumbien war, fand vom 6. bis zum 11. September 2017 statt. Die Pilgerreise verlief unter dem Motto „Tun wir den ersten Schritt!“, das an den Friedensprozess in Kolumbien anknüpft, der einen über 50 Jahre andauernden Bürgerkrieg endete. Der Papst besuchte folgende Städte: Bogota, Villavicencio, Rionegro, Medellín und Cartagena.

In den analysierten Portalen wurden 29 Texte zum Thema dieses Besuchs veröffentlicht. Der erste war die Nachricht vom 24. Juli 2017 im Portal www.interia.pl. Es war eine Nachricht darüber, dass Revolutionäre Streitkräfte Kolumbiens (FARC), d. h. eine kommunistische Guerillabewegung, die im November 2016 einen Friedensvertrag mit der kolumbianischen Regierung abschloss, bekannt gab, dass sie in eine politische Partei noch vor Ankunft des Papstes umgewandelt wird, um den Friedensprozess fortzusetzen ${ }^{19}$. Die letzte Publikation erschien am 13. September 2017 im Portal www.onet.pl. Der Autor beschreibt die Situation, in der Papst Franziskus während des Besuchs in Kolumbien eine an Depression und Toxoplasmose leidende Frau von der Euthanasie abbrachte. Nach dem Gespräch mit dem Papst im Hof der Nuntiatur in Bogota verzichtete 56-jährige Consuelo

${ }^{18}$ Siehe [ohne Autor], Watykan wyjawił cud fatimski. To 5-latek z uszkodzonym mózgiem, 12.05.2017, in: https://www.o2.pl/hot/watykan-zdradzil-cud-fatimski-potrzebowali-go-dokanonizacji-6121911515191425a, [Zugriff 25.03.2018]; [ohne Autor], To był prawdziwy cud, 12.05.2017, in: https://www.o2.pl/hot/nawet-lekarze-uwierzyli-ten-chlopiec-wyzdrowialprzez-cud-6121751555360385a, [Zugriff 25.03.2018]; [ohne Autor], Fatima - ujawniono przypadek cudu, 12.05.2017, in: http://wiadomosci.onet.pl/swiat/fatima-ujawniono-przypadek-cudu/52mh93n, [Zugriff 25.03.2018.]; [ohne Autor], Papież w Fatimie zawierzył siebie opiece Matki Bożej, 13.05.2017, in: http://fakty.interia.pl/galerie/swiat/zdjecie,ild,2303100,iAId,248650, [Zugriff 25.03.2018.]; [ohne Autor], Papież w Fatimie: Maryja nie jest świętą z obrazka, 12.05.2017, in: http://wiadomosci.onet.pl/swiat/papiez-w-fatimie-zawierzyl-siebieopiece-matki-bozej/b33ebbm, [Zugriff 25.03.2018].

${ }^{19}$ Siehe [ohne Autor], Kolumbijska partyzantka zostanie partia polityczna, 24.07.2017, in: http://fakty.interia.pl/swiat/news-kolumbijska-partyzantka-zostanie-partiapolityczna,nId,2420938, [Zugriff 25.03.2018]. 
Córdoba auf den für Ende September dieses Jahres geplanten assistierten Suizid ${ }^{20}$. Die mit der Pilgerreise verbundenen Berichte wurden während ihrer Dauer und der letzte drei Tage danach veröffentlicht. Sie betrafen am meisten die päpstliche Lehre zum Thema des Friedens; es gab auch Kommentare über die Drogenkartelle und den Terrorismus. Es wurden am häufigsten Pressemitteilungen veröffentlicht (27). Es wurden 3 Nachrichten vor der päpstlichen apostolischen Reise und 4 danach veröffentlicht. Die letzte davon wurde ein Monat nach ihrer Beendigung veröffentlicht und knüpfte an die Person von Consuelo Córdoba, die Selbstmord begehen wollte, an.

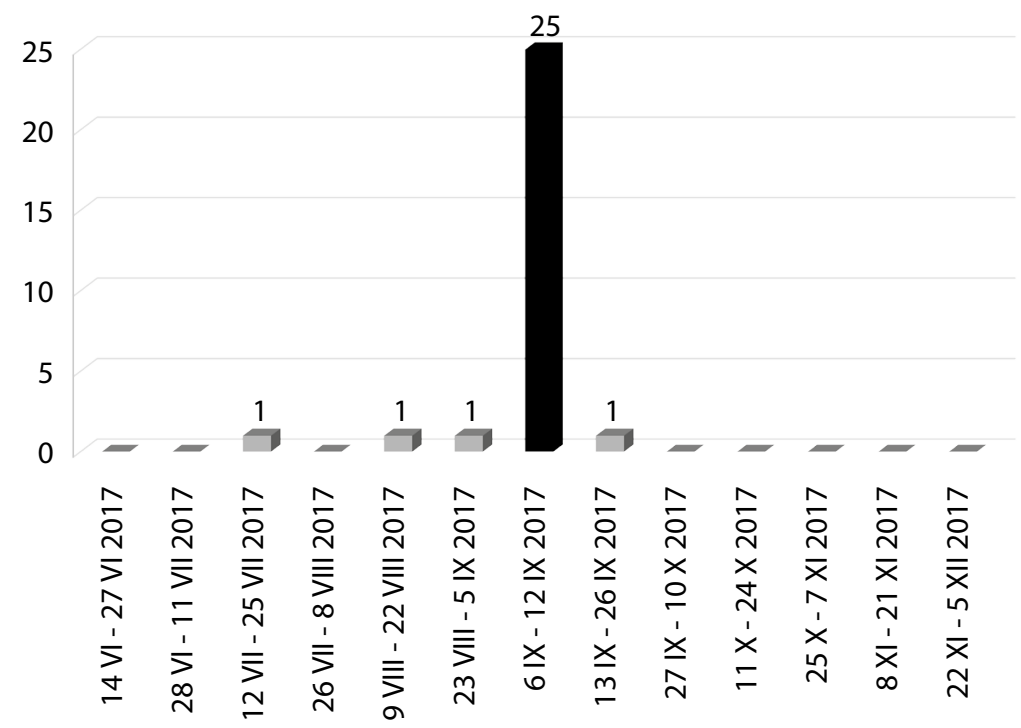

Diagramm Nr. 9. Anzahl der Publikationen zum Thema des Besuchs von Papst Franziskus in Kolumbien in den polnischen Portalen nach dem Veröffentlichungstag, $\mathrm{N}=29$

Quelle: Newspoint

Die meisten Nachrichten zum Thema der päpstlichen Pilgerreise nach Kolumbien veröffentlichte das Portal www.interia.pl (10), was ihm rund 35\% des

${ }^{20}$ Siehe [ohne Autor], Papież odwiódł od eutanazji Kolumbijkę podczas spotkania w Bogocie, 13 IX 2017 r., w: http://wiadomosci.onet.pl/religia/papiez-odwiodl-od-eutanazjikolumbijke-podczas-spotkania-w-bogocie/trk11mh, [Zugriff 25.03.2018]. 
Anteils am Markt der Internetnachrichten ausmacht. Die weiteren Portale unter Berücksichtigung der Publikationsanzahl waren entsprechend: www.onet.pl (7), www.gazeta.pl (4), www.wp.pl (4), www.o2.pl (3) und www.fakt.pl (1).

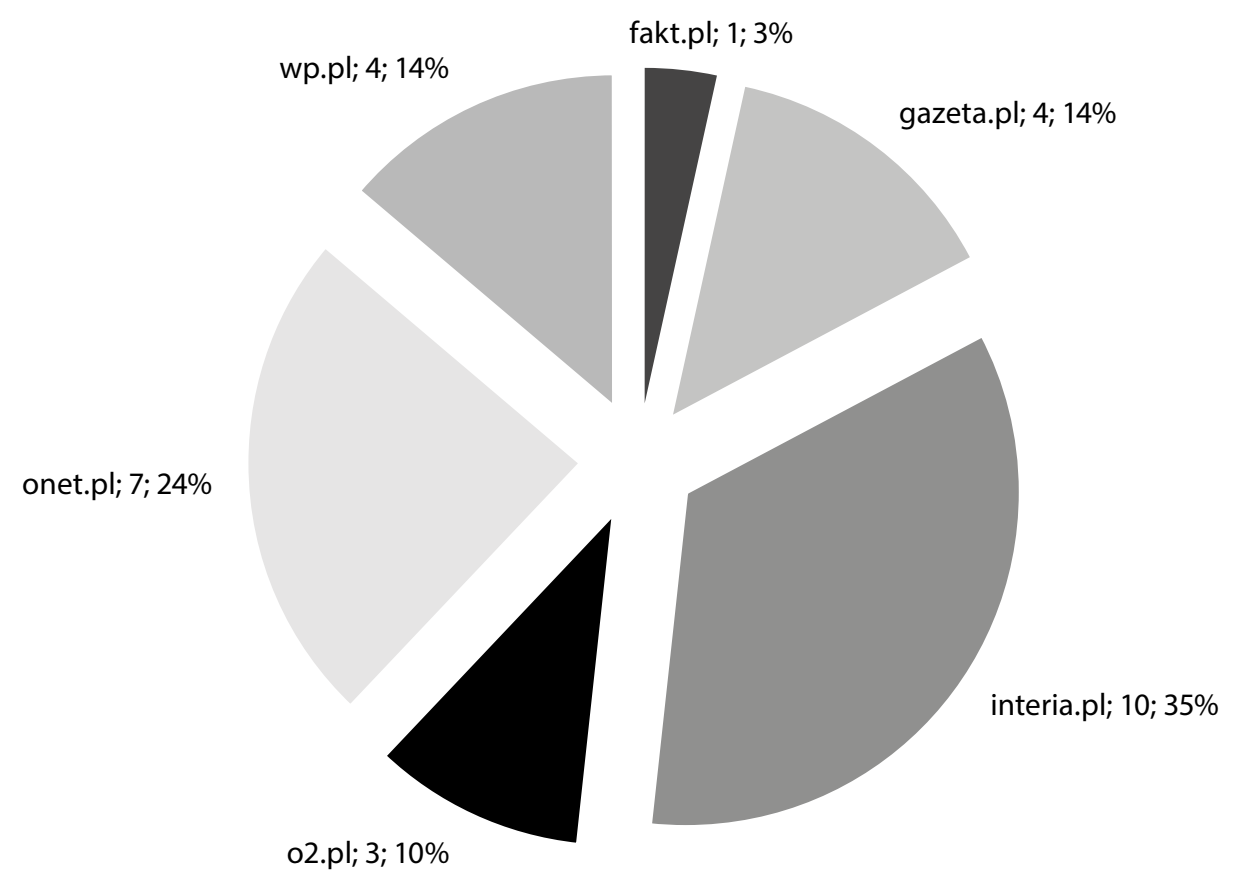

Diagramm Nr. 10. Anzahl der Publikationen zum Thema des Besuchs von Papst Franziskus in Kolumbien in den polnischen Portalen nach dem Veröffentlichungsort, N=29 Quelle: Newspoint

Weitere Stufe der auszuführenden Forschungen war Ermittlung der Kommunikationsweise über diese apostolische Pilgerreise von Papst Franziskus. Aus den durchgeführten Forschungen geht es hervor, dass 28/29 der veröffentlichten Nachrichten positiv (3) bzw. neutral waren (25). Es wurde lediglich 1 negativer Kommentar veröffentlicht. Die negative Nachricht betraf nicht das Hauptthema der Pilgerreise, sondern die Tatsache, dass Papst Franziskus erklärte bei der Rückreise aus Kolumbien nach Rom, dass die Geschichte beurteile diejenigen, die Klimaänderungen bestreiten. Der Kommentator wies darauf hin, dass es eine 


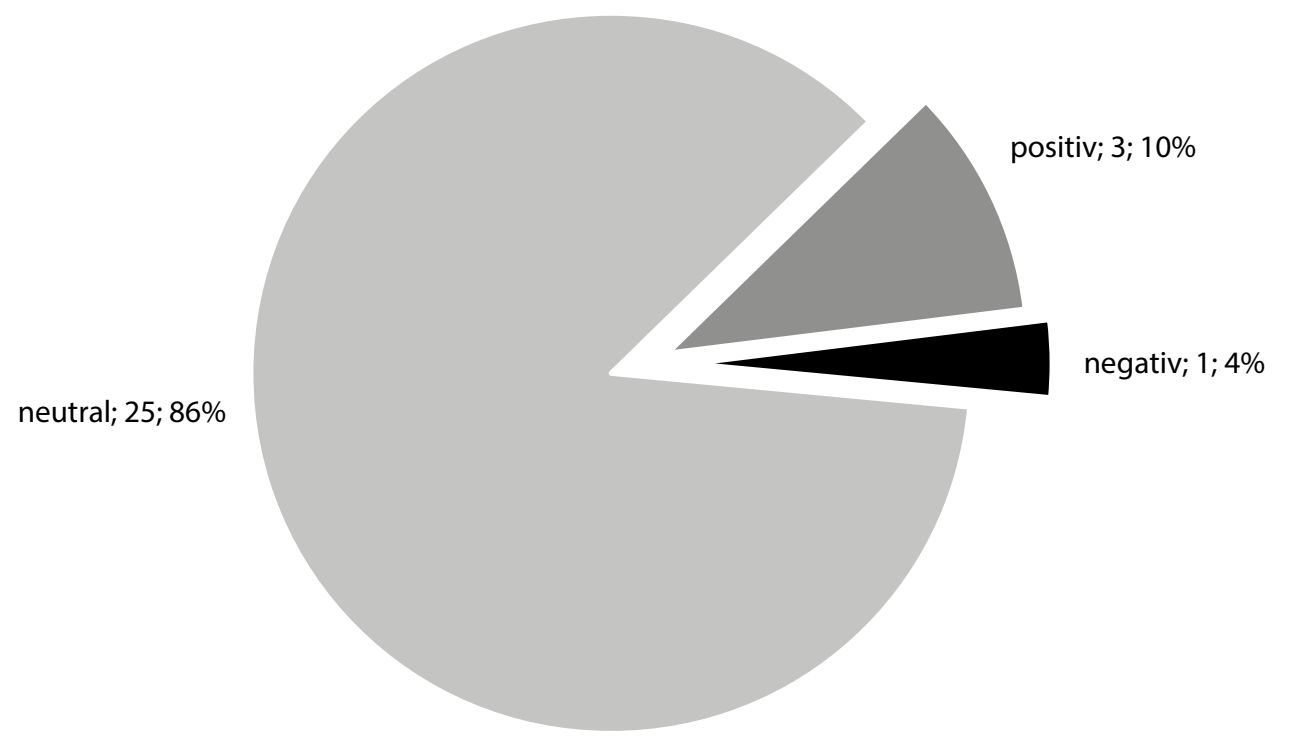

Diagramm Nr. 11. Anzahl der Publikationen zum Thema des Besuchs von Papst Franziskus in Kolumbien in den polnischen Portalen nach der Veröffentlichungsart, N=29 Quelle: Newspoint

deutliche Anspielung auf Präsidenten von USA Donald Trump sei, und er nahm es negativ als Einmischen in interen Angelegenheiten der Staaten $a^{21}$.

Der Anteil an negativen, positiven und neutralen Nachrichten war unter den analysierten Portalen vergleichbar. Die negative und zugleich die meisten positiven Nachrichten erschienen im Portal www.interia.pl.

Die meisten geforschten Internetportale bedienen sich der Mitteilungen aus den Diensten PAP, KAI, RAI und RV. Die Aussage der Nachrichten war in der Regel neutral, ohne Angabe des Autors. Die negative Nachricht sprach über die Maßnahmen zur Verbesserung des sich verschlechternden Klimas. Negativ wurde dort das Engagement des Papstes in interne Angelegenheiten der Staaten beurteilt ${ }^{22}$. Materialien, die die Aussage und den Inhalt der päpstlichen Reden vertieften,

${ }^{21}$ Siehe [ohne Autor], Wyraźna aluzja papieża pod adresem Donalda Trumpa, 11.09.2017, in: http://fakty.interia.pl/swiat/news-wyrazna-aluzja-papieza-pod-adresem-donaldatrumpa,nId,2439175, [Zugriff 25.03.2018].

${ }^{22}$ Siehe [ohne Autor], Wyraźna aluzja papieża pod adresem Donalda Trumpa, 11.09.2017, in: http://fakty.interia.pl/swiat/news-wyrazna-aluzja-papieza-pod-adresem-donalda-trumpa,nId,2439175, [Zugriff 25.03.2018]. 


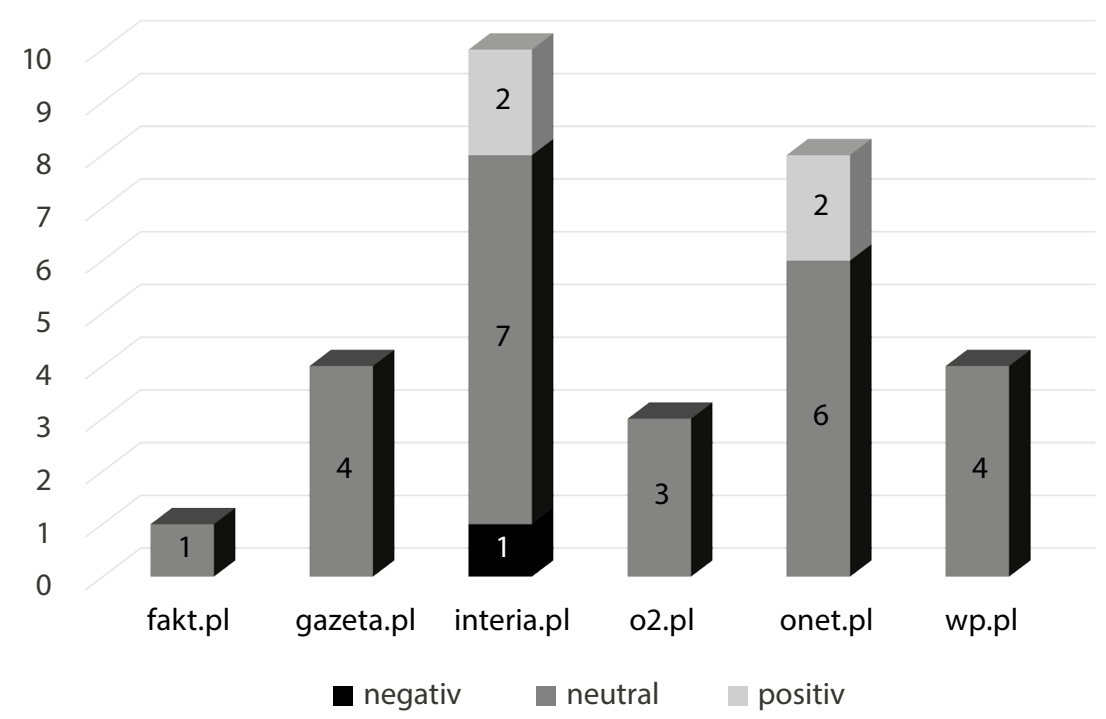

Diagramm Nr. 12. Anzahl der Publikationen zum Thema des Besuchs von Papst Franziskus in Kolumbien in den polnischen Portalen nach dem Veröffentlichungsort und -art, $\mathrm{N}=29$

Quelle: Newspoint

wurden wenig veröffentlicht. Die letzten davon waren Nachrichten betreffend die Rückkehr des Papstes nach Rom, man betonte auch die Klimaprobleme, das Stolpern und der Sturz des Papstes und man beschäftigte sich weniger mit den Analysen der Pilgerreise ${ }^{23}$. Während der Pilgerreise konzentrierten sich die Publizisten auf die Äußerungen des Papstes bezüglich des Friedens und der Maßnahmen zur Vermeidung des Bürgerkrieges mit den Drogenkartellen. Sie benachrichtigten

${ }^{23}$ Sieh [ohne Autor], Papież Franciszek ostrzega: zignorowanie tego problemu sprawi, że ludzie wyginq, 12.09.2017, in: https://www.o2.pl/hot/papiez-franciszek-ostrzegazignorowanie-tego-problemu-sprawi-ze-ludzie-wygina-6165217042790529a, [Zugriff 25.03.2018]; [ohne Autor], Papież Franciszek stracił równowage $i$ uderzył się w głowę, 12.09.2017, in: http://wiadomosci.onet.pl/swiat/papiez-franciszek-stracil-rownowagei-uderzyl-sie-w-glowe/tw1z2v3, [Zugriff 25.03.2018]; [ohne Autor], Papież Franciszek ostrzega: zignorowanie tego problemu sprawi, że ludzie wygina, 12.09.2017, in: http://wiadomosci.wp.pl/papiez-franciszek-ostrzega-zignorowanie-tego-problemu-sprawi-ze-ludziewygina-6165217042790529a, [Zugriff 25.03.2018]; [ohne Autor], Papież odwiódł od eutanazji Kolumbijkę podczas spotkania w Bogocie, 13.09.2017, in: http://wiadomosci.onet.pl/ religia/papiez-odwiodl-od-eutanazji-kolumbijke-podczas-spotkania-w-bogocie/trk11mh, [Zugriff 25.03.2018]. 
über das Gespräch des Bischofs von Rom mit dem Klerus und über die Ekklesiologie des Lateinamerikas. Sie betonten die Inhalte im Zusammenhang mit den Kinder- und Frauenrechten ${ }^{24}$.

\subsection{November - 2. Dezember - Myanmar (Birma), Bangladesch}

Die letzte apostolische Reise von Papst Franziskus im analysierten Jahr führte nach Myanmar (Birma) und Bangladesch und fand vom 27. November bis zum 2. Dezember 2017 statt. Der Papst besuchte u. a. Rangun, Naypyidaw (Birma) und Dhaka (Bangladesch). Es war der erste in der Geschichte päpstliche Besuch in Myanmar und der zweite in Bangladesch, der früher von Johannes Paul II. während der apostolischen Reisen im Jahre 1986 besucht wurde. Eines der Ziele der Pilgerreise von Franziskus war auf die Verfolgungen des Volkes Rohingya, einer muslimischen Ethnie, die buddhistisches Myanmar wohnt, aufmerksam machen. Die Pilgerreise verlief unter dem Motto „Liebe und Frieden“.

In den analysierten Portalen wurden 17 Texte zum Thema dieses Besuchs veröffentlicht. Der erste war die Nachricht vom 22. November 2017 im Portal www.onet.pl. Es war eine Nachricht darüber, dass Papst Franziskus sich während des Besuchs in Bangladesch mit den Vertretern der Minderheit Rohingya trifft, was bei der Pressekonferenz zum Thema der besprochenen Pilgerreise von Franziskus angekündigt wurde. Rohingya sind Muslime aus Westbirma, eine der

${ }^{24}$ Siehe [ohne Autor], Kolumbia: Symboliczny gest papieża Franciszka, 07.09.2017, in: http://fakty.interia.pl/swiat/news-kolumbia-symboliczny-gest-papieza-franciszka,nId,2437528, [Zugriff 25.03.2018]; [Bez autora], Surowe słowa Franciszka do hierarchów kościelnych. „Nie można tak postępować”, 09.09.2017, in: http://wiadomosci.wp.pl/surowe-slowa-franciszka-do-hierarchow-koscielnych-nie-mozna-tak-postepowac-6163804301813889a, [Zugriff 25.03.2018]; [ohne Autor], Papież beatyfikował męczenników z Kolumbii, 09.09.2017, in: http://fakty.interia.pl/wideo/video,vId,2382259, Zugriff 25.03.2018]; [ohne Autor], Papież do ofiar wojny domowej: Chciałbym płakać z wami, 9.09.2017, in: http://fakty.interia.pl/ religia/news-papiez-do-ofiar-wojny-domowej-chcialbym-plakac-z-wami,nId,2438577, [Zugriff 25.03.2018]; M. Stasiński, Papież w Kolumbii namawiał do pojednania po 50 latach wojny domowej. I mówił, że przemoc wobec kobiet to „skutek samczej kultury”, 10.09.2017, in: http:// wyborcza.pl/7,75399,22351375,papiez-w-kolumbii-namawial-do-pojednania-po-50-latachwojny.html, [Zugriff 25.03.2018]; [ohne Autor], Papież Franciszek: Nie pogodzimy się z maltretowaniem dzieci, 10.09.2017, in: http://fakty.interia.pl/swiat/news-papiez-franciszek-niepogodzimy-sie-z-maltretowaniem-dzieci,nId,2438725, [Zugriff 25.03.2018]; [ohne Autor], Papież: nie pogodzimy się z maltretowaniem dzieci, 10.09.2017, in: http://wiadomosci.onet. $\mathrm{pl} /$ swiat/papiez-nie-pogodzimy-sie-z-maltretowaniem-dzieci/3d1164l, [Zugriff 25.03.2018]. 
am meisten verfolgten Minderheiten auf der Welt von den radikalen buddhistischen Gruppen. Die muslimischen Flüchtlinge fliehen vor Verfolgung nach Bangladesch ${ }^{25}$. Die letzte Publikation erschien am 3. Dezember 2017 im Portal www. onet.pl und war mit dem traditionellen Gespräch der Journalisten mit dem Papst im Flugzeug während der Rückkehr nach Rom verbunden. Der Bischof von Rom betonte das Engagement von Bangladesch für die Annahme von 700 Tsd. Flüchtlingen aus Birma sowie sprach über die Länder, die sich vor der Annahme der Flüchtlinge verschließen. Ein weiteres vom Bischof von Rom angesprochenes Thema war Frieden und Prüfung der Legalität des Besitzes von Nuklearwaffen im

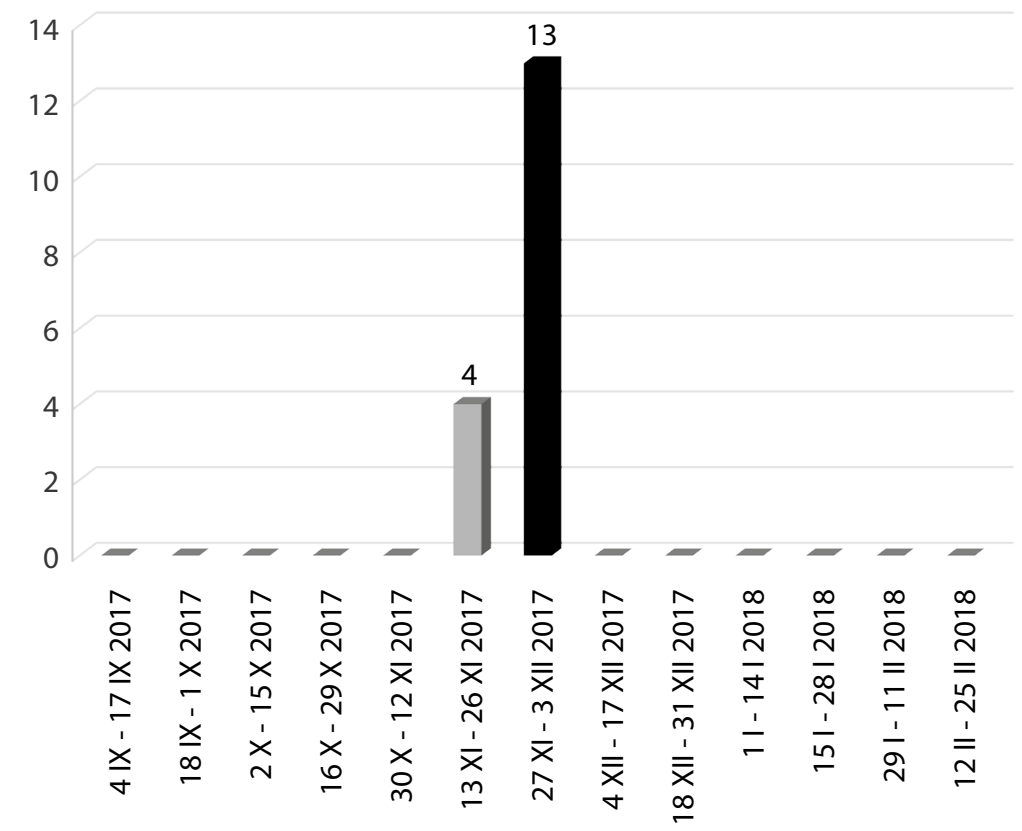

Diagramm Nr. 13. Anzahl der Publikationen zum Thema des Besuchs von Papst Franziskus in Myanmar (Birma) und Bangladesch in den polnischen Portalen nach dem Veröffentlichungstag, $\mathrm{N}=17$

Quelle: Newspoint

${ }^{25}$ Siehe [ohne Autor], Watykan: papież spotka się w Bangladeszu z przedstawicielami Rohingja, 22.11.2017, in: http://wiadomosci.onet.pl/swiat/watykan-papiez-spotka-sie-w-bangladeszu-z-przedstawicielami-rohingja/lbzwygm, [Zugriff 25.03.2018]. 
Zusammenhang mit dem internationalen öffentlichen Recht ${ }^{26}$. Die mit der Pilgerreise verbundenen Berichte wurden während ihrer Dauer und der letzte ein Tag danach veröffentlicht. Sie betrafen am meisten die päpstliche Lehre zum Thema des Friedens; es gab auch Kommentare über Flüchtlinge und Religionsextremisten. Es wurden am häufigsten Pressemitteilungen veröffentlicht (16). Es wurden 4 Nachrichten in der Zeit vor der päpstlichen apostolischen Reise und 3 danach veröffentlicht. Die letzte davon war der Bericht vom Gespräch des Papstes mit den Journalisten.

Die meisten Nachrichten zum Thema der päpstlichen Pilgerreise nach Bangladesch veröffentlichte das Portal www.onet.pl (8), was ihm rund 47\% des Anteils

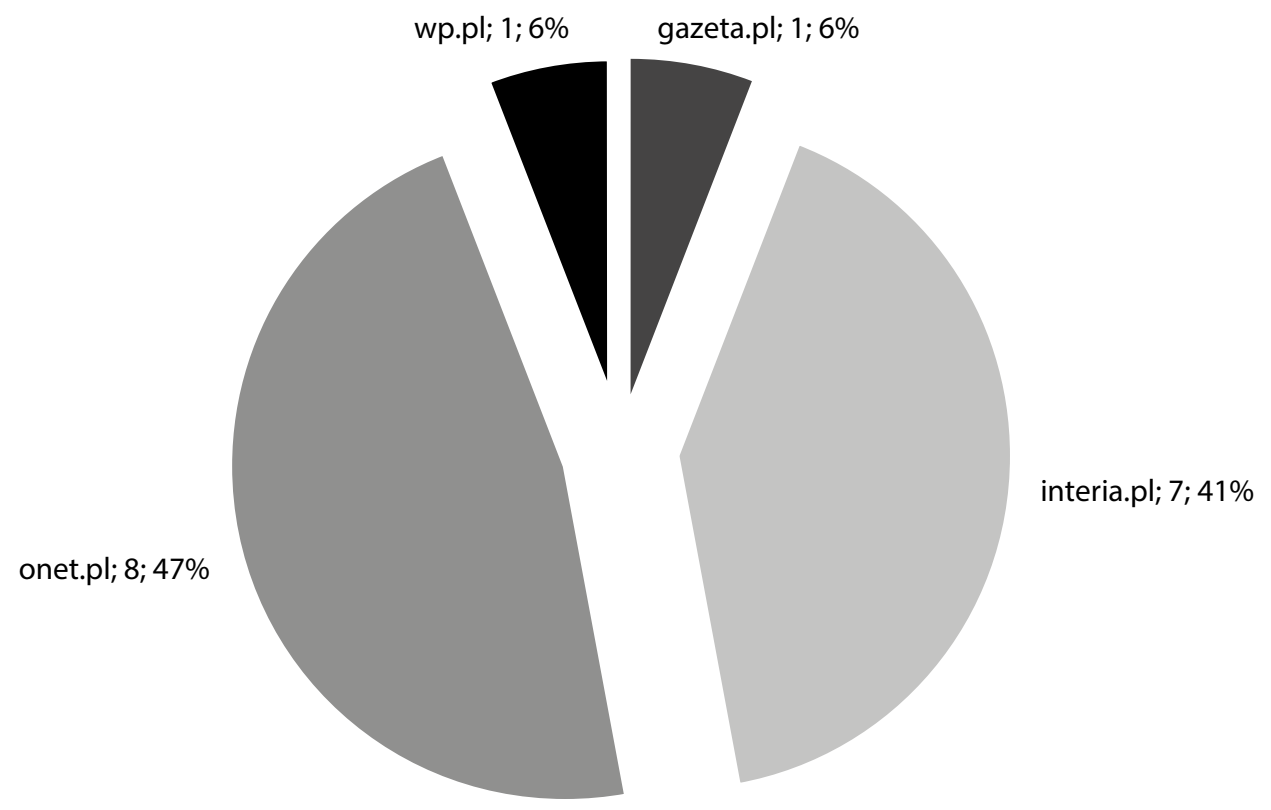

Diagramm Nr. 14. Anzahl der Publikationen zum Thema des Besuchs von Papst Franziskus in Myanmar (Birma) und Bangladesch in den polnischen Portalen nach dem Veröffentlichungsort, $\mathrm{N}=17$

Quelle: Newspoint

${ }^{26}$ Siehe [ohne Autor], Papież: jesteśmy na granicy legalności broni nuklearnej, 03.12.2017, in: http://wiadomosci.onet.pl/swiat/papiez-jestesmy-na-granicy-legalnosci-broni-nuklearnej/6qf0p76, [Zugriff 25.03.2018]. 


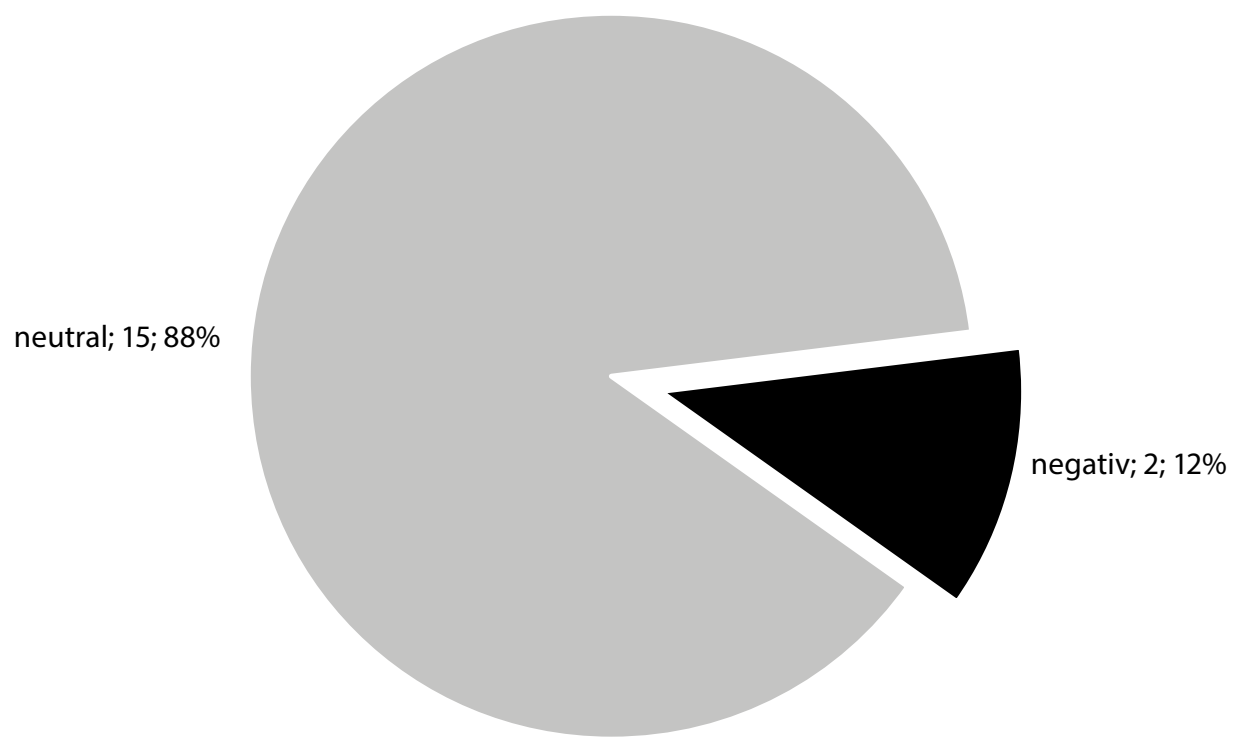

Diagramm Nr. 15. Anzahl der Publikationen zum Thema des Besuchs von Papst Franziskus in Myanmar (Birma) und Bangladesch in den polnischen Portalen, N=17 Quelle: Newspoint

am Markt der Internetnachrichten ausmacht. Die weiteren Portale unter Berücksichtigung der Publikationsanzahl waren entsprechend: www.interia.pl (7), www. wp.pl (1) sowie www.gazeta.pl (1). In den Portalen www.o2.pl und www.fakt.pl erschienen keine Nachrichten.

Weitere Stufe der auszuführenden Forschungen war Ermittlung der Kommunikationsweise über diese apostolische Pilgerreise von Papst Franziskus. Aus den durchgeführten Forschungen geht es hervor, dass 15/17 der veröffentlichten Nachrichten neutral waren (15). Es wurden 2 negative Kommentare veröffentlicht und es gab keine positiven. Es ging daraus hervor, dass es am meisten nachgedruckten Agenturnachrichten waren. Die negativen Nachrichten betrafen die wenige Entschlossenheit des Papstes, laut den Kommentatoren, in den Aussagen zum Thema der verfolgten muslimischen Rohingya und dass bei dieser Pilgerreise Indien nicht besuchte ${ }^{27}$.

${ }^{27}$ Siehe J. Kociszewski, Papież Franciszek unika kontrowersji, żeby chronić chrześcijan w Mjanmie. Ryzykuje swoja reputacja, 28.11.2017, in: https://wiadomosci.wp.pl/papiez-franciszek-unika-kontrowersji-zeby-chronic-chrzescijan-w-mjanmie-ryzykuje-swoja-reputacja6192625271703681a, [Zugriff 25.03.2018]; [ohne Autor], Indie: wierni rozczarowani brakiem 


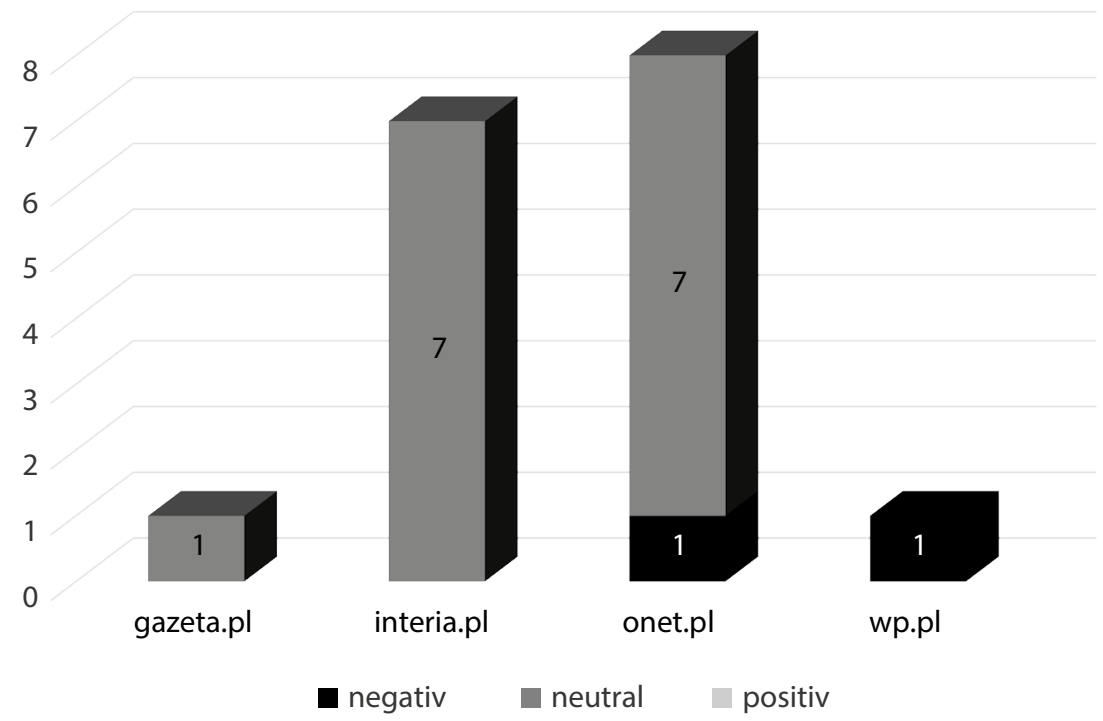

Diagramm Nr. 16. Anzahl der Publikationen zum Thema des Besuchs von Papst Franziskus in Myanmar (Birma) und Bangladesch in den polnischen Portalen nach dem Veröffentlichungsort und -art, $\mathrm{N}=17$

Quelle: Newspoint

Der Anteil an negativen, positiven und neutralen Nachrichten war unter den Portalen www.onet.pl, www.interia.pl und www.gazeta.pl vergleichbar. Negativ benachrichtigte über die päpstliche Pilgerreise das Portal www.wp.pl.

Die meisten geforschten Internetportale bedienen sich der Mitteilungen aus den Diensten PAP, KAI, RAI und RV, deshalb sind viele Publikationen neutral, nicht emotional geladen. Zwei Nachrichten sprachen negativ über zu große Zurückhaltung des Papstes in seinen Äußerungen zum Thema der von den Buddhisten verfolgten muslimischen Minderheit sowie über die Nichterweiterung der Pilgerreise um Indien ${ }^{28}$. Die die Pilgerreise ansagenden Texte konzentrierten sich vor allem

wizyty papieża, 30.11.2017, in: http://wiadomosci.onet.pl/religia/indie-wierni-rozczarowani-brakiem-wizyty-papieza/s6z0d8s, [Zugriff 25.03.2018].

${ }^{28}$ Siehe J. Kociszewski, Papież Franciszek unika kontrowersji, żeby chronić chrześcijan w Mjanmie. Ryzykuje swojq reputacja, 28.11.2017, in: https://wiadomosci.wp.pl/papiez-franciszek-unika-kontrowersji-zeby-chronic-chrzescijan-w-mjanmie-ryzykuje-swoja-reputacja6192625271703681a, [Zugriff 25.03.2018]; [ohne Autor], Indie: wierni rozczarowani brakiem wizyty papieża, 30.11.2017, in: http://wiadomosci.onet.pl/religia/indie-wierni-rozczarowani-brakiem-wizyty-papieza/s6z0d8s, [Zugriff 25.03.2018]. 
auf die Fragen des internen Friedens, der Flüchtlinge und des religionsübergreifenden Dialogs ${ }^{29}$. Während der Pilgerreise erschienen ein paar Nachrichten über die Pilgerreise von Papst Franziskus nach Myanmar (Birma), Bangladesch. Man benachrichtige über den Besuch und betonte das Problem der Flüchtlinge, des religionsübergreifenden Krieges und des religionsübergreifenden Dialogs. Der Papst drückte seine Besorgnis wegen der Gesellschaften aus, die für die Hilfe anderen verschlossen sind. In den Medienberichten war besonders das Problem des Volkes Rohingya zu hören ${ }^{30}$. Zusammenfassungen der Pilgerreise, der Reflexionen, darunter theologisch, wurden zu diesem Thema nicht veröffentlicht. Die letzten Nachrichten fielen mit dem letzten Tag der Pilgerreise zusammen, obwohl sie aufgrund des Zeitunterschieds ein Tag später veröffentlicht wurden.

\section{THEOLOGISCHE ANALYSE DER VERÖFFENTLICHTEN INHALTE}

Die meisten Nachrichten bezüglich der päpstlichen Pilgereisen waren Agenturnachrichten, am häufigsten nach der Katholischen Informationsagentur (KAI), der Polnischen Nachrichtenagentur (PAP) und der Rundfunkinformationsagentur (RAI), dem Radio Vatikan (RV) veröffentlicht. Ihre Anzahl beträgt 75 von 84, was $89,3 \%$ der gesamten Informationen darstellt. Es sind Inhalte, die ohne Angabe des Autors und dupliziert ohne Beurteilung des jeweiligen Ereignisses bzw.

${ }^{29}$ Siehe [ohne Autor], Watykan: papież spotka się w Bangladeszu z przedstawicielami Rohingja, 22.11.2017, in: http://wiadomosci.onet.pl/swiat/watykan-papiez-spotka-sie-w-bangladeszu-z-przedstawicielami-rohingja/lbzwygm, [Zugriff 25.03.2018]; [ohne Autor], Papież Franciszek w niedzielę udaje się do Birmy i Bangladeszu, 27.11.2017, in: http://fakty.interia. $\mathrm{pl} /$ polska/news-papiez-franciszek-w-niedziele-udaje-sie-do-birmy-i-banglades,nId,2469496, [Zugriff 25.03.2018]; [ohne Autor], Kim jest lud Rohingya?, 28.11.2017, in: http://wiadomosci. onet.pl/swiat/kim-jest-lud-rohingya/2w7pkf4, [Zugriff 25.03.2018].

${ }^{30}$ Siehe [ohne Autor], Papież Franciszek w Birmie, 29.11.2017, in: http://fakty.interia. pl/galerie/swiat/zdjecie,ild,2430775,iAId,274933, [Zugriff 25.03.2018]; [ohne Autor], Papież: nie odpowiadać przemoca na przemoc, 29.11.2017, in: http://wiadomosci.onet.pl/swiat/ papiez-nie-odpowiadac-przemoca-na-przemoc/fj9skf2, [Zugriff 25.03.2018]; [ohne Autor], Spotkanie papieża z uchodźcami Rohingja, 01.12.2017, in: http://fakty.interia.pl/galerie/ swiat/zdjecie,ild,2432601,iAId,275271, [Zugriff 25.03.2018]; [ohne Autor], Papież Franciszek powrócił z pielgrzymki, 02.12.2017, in, w: http://fakty.interia.pl/raporty/raport-nowy-papiez/aktualnosci/news-papiez-franciszek-powrocil-z-pielgrzymki,nId,2472943, [Zugriff 25.03.2018]; [ohne Autor], Papież: zamknięte społeczeństwo widzi wokół siebie wrogów, 02.12.2017, in: http://wiadomosci.onet.pl/swiat/papiez-zamkniete-spoleczenstwo-widziwokol-siebie-wrogow/f1p5hx3, [Zugriff 25.03.2018]. 
der päpstlichen Lehre veröffentlicht werden. Die gleiche Nachricht erscheint in mehreren Internetportalen. Die Nachrichtenagenturen konzentrieren sich fast ausschließlich auf neutrale Nachrichten und auf päpstliche Pilgerreisen werden keine dedizierten Journalisten entsandt. Dies geschieht aus finanziellen Gründen und auch wegen keinem größeren Interesse für die Pilgerreisen, was die niedrige Anzahl der Nachrichten zeigt. Negative Informationen werden gleichmäßig in verschiedenen Portalen veröffentlicht, man kann somit nicht feststellen, dass die päpstliche Lehre und die Person des Papstes in einem der Portale in höherem Maße infrage gestellt wird. Die am meisten in der Medienübertragung vorkommenden Agenturmitteilungen informieren über die gegebenen Ereignisse, sie kommentieren sie allerdings selten. Eine Ausnahme sind Mitteilungen Dossier oder ein Ereignis analysierende Berichte. Unter den Publikationen beziehen sich die meisten auf Organisationsangelegenheiten oder auf Sachen, die nicht direkt mit dem Inhalt der päpstlichen Lehre zusammenhängen.

Vom 28. bis zum 29. April 2017 besuchte Franziskus Ägypten und es war seine erste Missionspilgerreise im analysierten Jahr. Er traf sich mit dem Präsidenten und den Behörden des Landes, dem großen Imam der sunnitischen Al-AzharUniversität und dem koptischen Papst-Patriarchen, nahm an der Internationalen Konferenz „Religionen und Frieden“ teil und las hl. Messe mit Teilnahme von 20 Tausend Menschen. Das Motto des Besuchs waren die Worte: „Papst des Friedens in Ägypten des Friedens“. Es war seine 18. Auslandsreise. Der kurze, denn lediglich 27-stündige Aufenthalt des Heiligen Vaters in Kairo hatte einen religionsübergreifenden, ökumenischen und seelsorgerischen Charakter, was im Inhalt der Mitteilungen betont wurde. Vor allem wurde in den Texten der Dialog der Kirche mit dem sunnitischen Islam und seiner größten Autorität, der Al-Azhar-Universität betont. Bei der organisierten Friedenskonferenz appellierte der Papst zusammen mit dem Imam der Universität Ahmad al-Tayyeb, den er Bruder nannte, um laute und deutliche Verurteilung sämtlicher Formen von Gewalt, Rache und Hass, die im Namen von Religion oder Gott begangen werden. Er wies darauf hin, dass heute Bauer von Frieden und nicht Kampfhetzer; Feuermänner und nicht Konfliktstifter; Prediger von Versöhnung und nicht Fürsprecher von Zerstörung notwendig sind. Seinen Appell um Ablehnung sämtlicher Ideologie vom Bösen, der Gewalt und sämtlicher extremistischen Auslegungen wiederholte er beim Gespräch mit den Politikern und den Vertretern des Gesellschaftslebens von Ägypten. Er betonte, dass dieser Appell ist so wie nie nicht nur für den durch Krieg 
erschöpften Nahen Osten sondern auch für Europa und die ganze Welt wichtig diese Frage des religionsübergreifenden Dialogs war in der Medienübertragung der Pilgerreise bemerkbar. Der päpstliche Besuch war zweifellos Unterstützung für die größte christliche Kirche Ägyptens und für alle Kopten sowie er vertieft die guten koptisch-katholischen Beziehungen. Unter den veröffentlichten Texten bemerkte man, dass der Bischof von Rom das Zeugnis des „Ökumenismus des Blutes“ zurückrief, das sowohl in den ersten Jahrhunderten des Christentums als auch in unseren Zeiten vergossen wurde. Der Papst ermunterte die Katholiken keine Angst zu haben, alle, Freunde und Feinde zu lieben. Der Papst bezog sich auf die aktuelle Krise im Zusammenhang mit Nordkorea. Der Inhalt der veröffentlichten Texte hatte viel von der katholischen Soziallehre, dem Ökumenismus, dem religionsübergreifenden Dialog sowie der Moraltheologie ${ }^{31}$.

Unter dem Motto „Mit Maria, Pilger der Hoffnung und des Friedens“, hielt sich Franziskus am hundertsten Jahrestag der Offenbarungen von Muttergottes

${ }^{31}$ Siehe [ohne Autor], Papież apeluje ws. kryzysu wokół Korei Północnej, 30.04.2017, in: http://wiadomosci.wp.pl/papiez-o-grozbie-rozpadu-europy-i-kryzysie-wokol-korei-polnocnej-6117409480517249a, [Zugriff 25.03.2018]; [ohne Autor], Papież: to dobrze, że Rosja mówi o obronie chrześcijan, 30.04.2017, in: http://wiadomosci.onet.pl/swiat/papiez-to-dobrzeze-rosja-mowi-o-obronie-chrzescijan/hdqpy4t, [Zugriff 25.03.2018]; [ohne Autor], Papież w Egipcie. Zaostrzone środki bezpieczeństwa 27.04.2017, in: http://fakty.interia.pl/raporty/ raport-nowy-papiez/aktualnosci/news-papiez-w-egipcie-zaostrzone-srodki-bezpieczenstwa,nId,2387298, [Zugriff 25.03.2018]; [ohne Autor], Papież: Została okrutnie przelana krew bezbronnych, 28.04.2017, in: http://fakty.interia.pl/swiat/news-papiez-zostala-okrutnieprzelana-krew-bezbronnych,nId,2388441, [Zugriff 25.03.2018]; [ohne Autor], Papież przybył z wizyta do Egiptu, 28.04.2017, in: http://wiadomosci.onet.pl/swiat/papiez-franciszek-wegipcie/e5gz8xj, [Zugriff 25.03.2018]; [ohne Autor], Franciszek w Egipcie: jedyny dopuszczalny ekstremizm to radykalizm miłości, 29.04.2017, in: http://fakty.interia.pl/religia/news-papiezjedyny-dopuszczalny-ekstremizm-to-radykalizm-milosci,nId,2388479, [Zugriff 25.03.2018]; [ohne Autor], Papież Franciszek zakończył wizytę w Egipcie, 29.04.2017, in: http://fakty.interia.pl/galerie/swiat/zdjecie,iId,2303100,iAId,248650, [Zugriff 25.03.2018]; [ohne Autor], Franciszek zakończył wizytę w Egipcie, 29.04.2017, in: http://wiadomosci.onet.pl/swiat/ franciszek-zakonczyl-wizyte-w-egipcie/9qcmx62, [Zugriff 25.03.2018]; [ohne Autor], Papież Franciszek pomaga chrześcijanom w Egipcie. Niewiele zostało z nauk Jana Pawła II, 29.04.2017, in: http://wiadomosci.wp.pl/papiez-franciszek-pomaga-chrzescijanom-w-egipcie-niewiele-zostalo-z-nauk-jana-pawla-ii-6117189137930369a, [Zugriff 25.03.2018]; [ohne Autor], Franciszek w Egipcie: jedyny dopuszczalny ekstremizm to radykalizm miłości, 29.04.2017, in: http://wiadomosci.onet.pl/swiat/franciszek-w-egipcie-jedyny-dopuszczalny-ekstremizmto-radykalizm-milosci/7ltsk23, [Zugriff 25.03.2018]; [ohne Autor], Papież Franciszek: Europa jest zagrożona rozpadem, 30.04.2017, in: http://fakty.interia.pl/religia/news-papiez-franciszek-europa-jest-zagrozona-rozpadem,nId,2388621, [Zugriff 25.03.2018]. 
in Fátima vom 12. bis zum 13. Mai im dortigen Marienheiligtum in Portugal auf. Er sprach zwei von drei Teilnehmern der Ereignisse von 1917 heilig: Francisco und Jacinta Marto. In Fátima versammelten sich über Halbmillion Gläubiger aus 55 Ländern. Währen des Gebets in der Offenbarungskapelle betete der Papst um Frieden auf der Welt zwischen allen Ländern. Er betonte, er kommt hierher als Prophet und Bote, um die Füße allen beim gleich Tisch zu waschen, der uns einigt. Während der Heiligsprechungsmesse wies Franziskus auf den Mariencharakter der Kirche hin. Die Publizisten wiesen in ihren Übermittlungen auf die Mariologie und auch die katholische Soziallehre und die christliche Geistigkeit hin ${ }^{32}$.

Vom 6. bis zum 10. September besuchte Franziskus Bogota, Villavicencio, Medellín und Cartagena in Kolumbien. Es war die zweite Missionspilgerreise im analysierten Jahr. Das Motto des Besuchs waren die Worte „Tun wir den ersten Schritt“, die an den Versöhnungsprozess nach 50 Jahre dauerndem Bürgerkrieg in Kolumbien anknüpften. Es war die 20. apostolische Auslandsreise des Papstes und die fünfte nach Lateinamerika. Die Pilgerreise bestand $\mathrm{u}$. a. aus vier hl. Messen, Seligsprechung von zwei kolumbianischen Priestern-Märtyrern: Bischof

${ }^{32}$ Siehe [ohne Autor], Portugalia: Ponad milion osób towarzyszy papieżowi w Fatimie, 12.05.2017, in: http://fakty.interia.pl/swiat/news-portugalia-ponad-milion-osob-towarzyszy-papiezowi-w-fatimie,nId,2393349, [Zugriff 25.03.2018]; [ohne Autor], Watykan wyjawił cud fatimski. To 5-latek z uszkodzonym mózgiem, 12.05.2017, in: https://www.o2.pl/hot/watykan-zdradzil-cud-fatimski-potrzebowali-go-do-kanonizacji-6121911515191425a, [Zugriff 25.03.2018]; [ohne Autor], To był prawdziwy cud, 12.05.2017, in: https://www.o2.pl/hot/ nawet-lekarze-uwierzyli-ten-chlopiec-wyzdrowial-przez-cud-6121751555360385a, [Zugriff 25.03.2018]; [ohne Autor], Fatima - ujawniono przypadek cudu, 12.05.2017, in: http://wiadomosci.onet.pl/swiat/fatima-ujawniono-przypadek-cudu/52mh93n, [Zugriff 25.03.2018.]; [ohne Autor], Papież w Fatimie zawierzył siebie opiece Matki Bożej, 13.05.2017, in: http:// fakty.interia.pl/galerie/swiat/zdjecie,ild,2303100,iAId,248650, [Zugriff 25.03.2018.]; [ohne Autor], Papież w Fatimie: Maryja nie jest świętą z obrazka, 12.05.2017, in: http://wiadomosci.onet.pl/swiat/papiez-w-fatimie-zawierzyl-siebie-opiece-matki-bozej/b33ebbm, [Zugriff 25.03.2018]; [ohne Autor], Franciszek ogłosił świętymi pastuszków z Fatimy. Za ich wstawiennictwem cudem ocalało dziecko, 13.05.2017, in: http://wiadomosci.onet.pl/swiat/franciszekoglosi-swietymi-pastuszkow-z-fatimy-za-ich-wstawiennictwem-cudem-ocalalo/rv2pm21, [Zugriff 25.03.2018]; [ohne Autor], 500 tys. osób na mszy w Fatimie, 13.05.2017, in: http:// wiadomosci.onet.pl/swiat/500-tys-osob-na-mszy-w-fatimie/ejlr8q4, [Zugriff 25.03.2018]; [ohne Autor], Fatima: Msza kanonizacyjna Hiacynty i Franciszka, 13.05.2017, in: http://fakty. interia.pl/swiat/news-fatima-msza-kanonizacyjna-hiacynty-i-franciszka,nId,2393443, [Zugriff 25.03.2018]; [ohne Autor], Papież w Fatimie: Polacy pielgrzymowali pieszo, 14.05.2017, in: http://fakty.interia.pl/raporty/raport-nowy-papiez/aktualnosci/news-papiez-w-fatimiepolacy-pielgrzymowali-pieszo,nId,2393671, [Zugriff 25.03.2018]. 
Jesús Emilio Jaramillo Monsalve und Priester Pedro María Ramírez Ramos, Gesprächen mit Behörden, Bischöfen, dem Lateinamerikanischen Bischofsrat (CELAM), mit Geistlichen, Behinderten und Jugendlichen. Der Papst kündigte an, dass seine Reise nach Kolumbien dem Staat beim Fortschritt im Friedensweg helfen sollte. Deswegen konzentrierte sich die Thematik seiner meisten Reden als auch der Medienübertragungen auf diese Sache. Der Papst ermutigte die Kolumbianer die Kultur des Treffens zu fördern, die es erfordert, im Zentrum aller politischen, sozialen und wirtschaftlichen Handlungen die Würde der menschlichen Person und das Respekt fürs Gemeingut zu platzieren. Er rief die jungen Kolumbianer auf, das Leiden anderen zu erkennen und zu verstehen, Förderer der Kultur des Treffens, der Verzeihung zu sein, damit sie bei der Heilung von Herzen und der Ansteckung mit jugendlicher Hoffnung helfen. Während des Gesprächs mit den Bischöfen warnte er davor, eine Kaste der sich unter der Diktatur des jetzigen Moments beugenden Beamten zu sein und damit sie den Schmeicheleien seitens der aktuellen Mächtigen nicht unterliegen. Der von den Publizisten übermittelte Inhalt war die päpstliche Lehre betreffen die Angelegenheiten des Umweltschutzes. Die Publizisten wiesen in ihren Übermittlungen auf die katholische Soziallehre als auch die christliche Geistigkeit und die Theologie des Dialogs hin ${ }^{33}$.

${ }^{33}$ Siehe [ohne Autor], Papież odwiódł od eutanazji Kolumbijkę podczas spotkania w Bogocie, 13.09.2017, w: http://wiadomosci.onet.pl/religia/papiez-odwiodl-od-eutanazjikolumbijke-podczas-spotkania-w-bogocie/trk11mh, [Zugriff 25.03.2018].

Siehe [ohne Autor], Kolumbia: Symboliczny gest papieża Franciszka, 07.09.2017, in: http://fakty.interia.pl/swiat/news-kolumbia-symboliczny-gest-papiezafranciszka,nId,2437528, [Zugriff 25.03.2018]; [ohne Autor], Wizyta papieża w Kolumbii. Ponad milion osób na mszy w Bogocie, 08.09.2017, in: http://fakty.interia.pl/swiat/newswizyta-papieza-w-kolumbii-ponad-milion-osob-na-mszy-w-bogoci,nId,2437990, [Zugriff 25.03.2018]; [ohne Autor], Surowe słowa Franciszka do hierarchów kościelnych. „Nie można tak postępować”, 09.09.2017, in: http://wiadomosci.wp.pl/surowe-slowa-franciszkado-hierarchow-koscielnych-nie-mozna-tak-postepowac-6163804301813889a, [Zugriff 25.03.2018]; [ohne Autor], Papież beatyfikował męczenników z Kolumbii, 09.09.2017, in: http://fakty.interia.pl/wideo/video,vId,2382259, Zugriff 25.03.2018]; [ohne Autor], Papież do ofiar wojny domowej: Chciałbym płakać z wami, 9.09.2017, in: http://fakty.interia.pl/religia/news-papiez-do-ofiar-wojny-domowej-chcialbym-plakac-z-wami,nId,2438577, [Zugriff 25.03.2018]; M. Stasiński, Papież w Kolumbii namawiał do pojednania po 50 latach wojny domowej. I mówił, że przemoc wobec kobiet to „skutek samczej kultury”, 10.09.2017, in: http://wyborcza.pl/7,75399,22351375,papiez-w-kolumbii-namawial-do-pojednania-po-50-latach-wojny.html, [Zugriff 25.03.2018]; [ohne Autor], Papież Franciszek miał wypadek $w$ papamobile. Rozbita twarz, krew na ubraniu, 10.09.2017, in: https://www. 
Vom 27. bis zum 30. November besuchte Franziskus Myanmar (früher Birma). Es war die erste Reise des Vorstehers der katholischen Kirche zu diesem südasiatischen Lande, dessen 90\% der Einwohner sich zum Buddhismus bekennen und es gibt ca. 700 Tsd. Katholiken. Es war die dritte Missionsreise im analysierten Jahr. Das Motto des Besuchs waren die Worte: „Liebe und Frieden“. Der Besuch bestand u. a. aus hl. Messen auf der Wiese in Yangon (Rangun) mit Teilnahme von 150 Tsd. Gläubigern sowie Gesprächen mit der Jugend in der Kathedrale, mit dem Höchsten Rat der Buddhistischen Mönche „Sangha“, mit Bischöfen und Vertretern der Behörden. Es war auch die erste Etappe der 21. Auslandsreise von Franziskus, bei dem besuchte er noch Bangladesch. Im Geiste von „Liebe und Versöhnung“ sowie „Einheit in Verschiedenheit" brach der Papst wieder zu einer apostolischen Reisen nach „Peripherien der Welt" auf - nach dem Staat, wo $80 \%$ der Bevölkerung arm sind, wovon $40 \%$ in extremer Armut leben, wie es die Autoren der Informationen in den Berichten betonten. Er verbrachte vier Tage im Staat von mehr als 52 Einwohnern, der zwar nach 60 Jahren militärischer Diktatur 2011 den Weg der Demokratie betritt, wird jedoch weiterhin durch Konflikte mit ethnischen Minderheiten geplagt und durch dramatische Krise im

o2.pl/hot/incydent-podczas-wizyty-papieza-w-kolumbii-obrazenia-na-twarzy-franciszka6164742675330689a, [Zugriff 25.03.2018]; [ohne Autor], Papież Franciszek: Nie pogodzimy się z maltretowaniem dzieci, 10.09.2017, in: http://fakty.interia.pl/swiat/news-papiezfranciszek-nie-pogodzimy-sie-z-maltretowaniem-dzieci,nId,2438725, [Zugriff 25.03.2018]; [ohne Autor], Papież: nie pogodzimy się z maltretowaniem dzieci, 10.09.2017, in: http:// wiadomosci.onet.pl/swiat/papiez-nie-pogodzimy-sie-z-maltretowaniem-dzieci/3d1l64l, [Zugriff 25.03.2018]; M. Kaczmarczyk, Papież nie ma wątpliwości. Ludzkość może zginąć, jeżeli nie poradzi sobie $z$ efektem cieplarnianym, 11.09.2017, in: http://next.gazeta.pl/next/7,151003,22358890,papiez-nie-ma-watpliwosci-ludzkosc-moze-zginac-jezeli-nie.html, [Zugriff 25.03.2018]; [ohne Autor], Papież Franciszek ostrzega: zignorowanie tego problemu sprawi, że ludzie wygina, 12.09.2017, in: https://www.o2.pl/hot/papiez-franciszekostrzega-zignorowanie-tego-problemu-sprawi-ze-ludzie-wygina-6165217042790529a, [Zugriff 25.03.2018]; [ohne Autor], Papież Franciszek stracił równowagę i uderzył się w głowę, 12.09.2017, in: http://wiadomosci.onet.pl/swiat/papiez-franciszek-stracil-rownowage-iuderzyl-sie-w-glowe/tw1z2v3, [Zugriff 25.03.2018]; [ohne Autor], Papież Franciszek ostrzega: zignorowanie tego problemu sprawi, że ludzie wyginq, 12.09.2017, in: http://wiadomosci. wp.pl/papiez-franciszek-ostrzega-zignorowanie-tego-problemu-sprawi-ze-ludzie-wygina6165217042790529a, [Zugriff 25.03.2018]; [ohne Autor], Papież odwiódł od eutanazji Kolumbijkę podczas spotkania w Bogocie, 13.09.2017, in: http://wiadomosci.onet.pl/religia/ papiez-odwiodl-od-eutanazji-kolumbijke-podczas-spotkania-w-bogocie/trk11mh, [Zugriff 25.03.2018]. 
Zusammenhang mit dem Volk Rohingya zerrissen. Durch seinen Besuch verstärkte Franziskus vor allem die partikulare Ekklesia, die Einheit in Verschiedenheit trotz den bestehenden Beschränkungen bauen soll. Diese Einheit wird auch in gemeinsamem Handeln, insbesondere mit den Buddhisten für den Frieden, das Respekt der Würde des Menschen und die Versöhnung ausgedrückt, was in der Medienübertragung betont wurde. Der Papst verurteilte den Terrorismus und den Religionsextremismus. Die Bekenner unterschiedlicher Religionen rief er zum Dialog und zum Respekt für richtige Verschiedenheit auf. Im breiteren Zusammenhang bestätigte der päpstliche Besuch, dass die Zukunft des Christentums in Asien liegt. Vom 30. November bis zum 2. Dezember hielt sich Franziskus in überwiegend muslimischen Bangladesch und seiner Hauptstadt Dhaka auf. Der unter dem Motto „Einvernehmen und Frieden“ verlaufende Besuch bestand u. a. aus hl. Messe im Park Suhrawardy Udyan mit Teilnahme von ca. 100 Tsd. Gläubigern, Gesprächen mit den Behörden, Bekennern verschiedenen Religionen, mit Bischöfen, Priestern, Klosterschwestern und Jugendlichen. Franziskus ist der dritte Papst, der Bangladesch besuchte. Das „Goldene Bengalen“ war die letzte Etappe der apostolischen Reise von Franziskus zu den „Peripherien der Welt“ - zum Land mit großer Überlegenheit der Muslime, armen und übervölkerten Land (160 Mio. Einwohner), voll von Sozial-, politischen und ökologischen Problemen, was die meisten Autoren der Nachrichten betonten. Die Katholiken bilden dort eine kleine Minderheit von 350 Tsd. Menschen, die zusammen mit den Bekennern anderer Religionen immer mehr Verfolgungen und Anschläge seitens der islamischen Fundamentalisten erfährt. Der Papst verstärke den Geist der Tolerany, der Versöhnung und des Friedens unter den bengalischen Katholiken und mit großer Anerkennung sprach über ihren Dienst für die Armen durch Bildungsapostolat, Krankenhäuser, Kliniken und Ambulanzen sowie verschiedene karitative Werke. Er ermutigte die dortige Gesellschaft vor allem den Frieden zwischen verschiedenen Gesellschaftsschichten zu suchen: den Reichen und den Armen, den Privilegierten und den Geschädigten sowie zum Dialog und Respekt für die „richtige Verschiedenheit“. Die Religionsvorsteher rief er zur Gestaltung der Kultur des Gesprächs, des Dialogs und der Zusammenarbeit im Dienst für die menschliche Familie auf sowie ermutigte, gegen den Virus von politischer Korruption, die destruktiven Religionsideologien, den Versuch, die Augen für die Bedürfnisse der Armen, der Flüchtlinge, der verfolgten Minderheiten und der Schwächsten zu handeln. Im diplomatischen Zusammenhang gehörte der Besuch von Franziskus 
Marcin Wrzos, Apostolische Auslandsreisen von Papst Franziskus, darunter Missionsreisen...

in beiden asiatischen Ländern zu den schwierigen aufgrund des muslimischen Volkes Rohingya, aus dem 630 Tsd. Menschen vor brutalen Verfolgungen seitens der buddhistischen Extremisten aus benachbartem Myanmar flieh und in Bangladesch Zuflucht fanden. In Myanmar, auf ausdrückliches Verlangen sowohl der lokalen Behörden als auch der Bischöfe, nannte der Papst den Namen dieser Ethnie nicht. In Bangladesch knüpfte er jedoch offen an die mit den „Flüchtling aus dem Rakhaing-Staat verbundene Krise an und rief zu internationalen Maßnahmen für ihre Lösung auf, worüber die Beobachter der Pilgerreise schrieben. Der Papst warnte auch vor Massenvernichtungswaffen. Die Publizisten wiesen auf die katholische Soziallehre, die Moraltheologie und auch die christliche Geistigkeit sowie den religionsübergreifenden Dialog hin $^{34}$.

${ }^{34}$ Zob. [ohne Autor], Włoscy rolnicy: import ryżu z terenów, skąd ucieka mniejszość Rohingjów, 19.11.2017, in: http://wiadomosci.onet.pl/swiat/wloscy-rolnicy-import-ryzu-zterenow-skad-ucieka-mniejszosc-rohingjow/cgj5rze, [Zugriff 25.03.2018]; [ohne Autor], Watykan: papież spotka się w Bangladeszu z przedstawicielami Rohingja, 22.11.2017, in: http:// wiadomosci.onet.pl/swiat/watykan-papiez-spotka-sie-w-bangladeszu-z-przedstawicielamirohingja/lbzwygm, [Zugriff 25.03.2018]; [ohne Autor], Papież Franciszek $w$ niedzielę udaje się do Birmy i Bangladeszu, 27.11.2017, in: http://fakty.interia.pl/polska/news-papiezfranciszek-w-niedziele-udaje-sie-do-birmy-i-banglades,nId,2469496, [Zugriff 25.03.2018]; [ohne Autor], Kim jest lud Rohingya?, 28.11.2017, in: http://wiadomosci.onet.pl/swiat/kim-jest-lud-rohingya/2w7pkf4, [Zugriff 25.03.2018]; J. Kociszewski, Papież Franciszek unika kontrowersji, żeby chronić chrześcijan w Mjanmie. Ryzykuje swoja reputacja, 28.11.2017, in: https://wiadomosci.wp.pl/papiez-franciszek-unika-kontrowersji-zeby-chronic-chrzescija n-w-mjanmie-ryzykuje-swoja-reputacja-6192625271703681a, [Zugriff 25.03.2018]; [ohne Autor], Papież Franciszek $w$ Birmie, 29.11.2017, in: http://fakty.interia.pl/galerie/swiat/ zdjecie,ild,2430775,iAId,274933, [Zugriff 25.03.2018]; [ohne Autor], Papież: nie odpowiadać przemoca na przemoc, 29.11.2017, in: http://wiadomosci.onet.pl/swiat/papiez-nie-odpowiadac-przemoca-na-przemoc/fj9skf2, [Zugriff 25.03.2018]; [ohne Autor], Spotkanie papieża z uchodźcami Rohingja, 01.11.2017, in: http://fakty.interia.pl/galerie/swiat/zdjecie,ild,2432601,iAId,275271, [Zugriff 25.03.2018]; [ohne Autor], Papież Franciszek powrócił z pielgrzymki, 02.11.2017, in: http://fakty.interia.pl/raporty/raport-nowy-papiez/aktualnosci/news-papiez-franciszek-powrocil-z-pielgrzymki,nId,2472943, [Zugriff 25.03.2018]; [ohne Autor], Papież: zamknięte społeczeństwo widzi wokół siebie wrogów, 02.11.2017, in: http://wiadomosci.onet.pl/swiat/papiez-zamkniete-spoleczenstwo-widzi-wokol-siebiewrogow/f1p5hx3, [Zugriff 25.03.2018], [ohne Autor], Papież: jesteśmy na granicy legalności broni nuklearnej, 03.11.2017, in: http://wiadomosci.onet.pl/swiat/papiez-jestesmy-nagranicy-legalnosci-broni-nuklearnej/6qf0p76, [Zugriff 25.03.2018]; [ohne Autor], Koniec wizyty papieża w Bangladeszu, 03.11.2017, in: http://fakty.interia.pl/galerie/swiat/zdjecie,iId,2433142,iAId,275389, [Zugriff 25.03.2018]. Umfangreicher sind die Pilgerreisen von Papst Franziskus in den Diensten KAI und PAP beschrieben. 
Bei den die päpstlichen Auslandspilgerreisen im Jahre 2017 betreffenden Publikationen geht es in den analysierten Internetportalen in fast 83\% um Mitteilungen von Nachrichtenagenturen. Es kommt vor, dass die Mitteilungen in verschiedenen Internetdiensten kopiert werden. Es sind somit weder umfangreiche noch vertiefte Kommentare hinsichtlich der päpstlichen Lehre. Sichtbar ist die Tendenz zu immer kürzeren Berichten aus den päpstlichen Pilgereisen in den inländischen Internetportalen. Die päpstlichen Pilgerreisen im Jahre 2017 waren insbesondere mit dem Ökumenismus, dem religionsübergreifenden Dialog, den Flüchtlingen, der Friedenseinführung oder Evangelisierung durch Arbeit zugunsten der ausgeschiedenen Menschen verbunden. Die in den Laienmedien veröffentlichten theologischen Inhalte waren somit mit der Ekklesiologie, der Theologie der Barmherzigkeit, der Moraltheologie, der Theologie der Geistigkeit, dem Dialog, dem Ökumenismus und dem religionsübergreifenden Dialog verbunden. Man konzentrierte sich darin auf der Darstellung der überzeugenden Kirche, die nach Papst Franziskus eine solche wird, wenn sie beginnt, mit Sorge um den Menschen, insbesondere um den ausgeschlossenen und ausgeschiedenen zu leben.

\section{PASTORALE SCHLUSSFOLGERUNGEN}

Die erste Papstbotschaft zum Welttag der Massenmedien wurde nach dem 2. Vatikanischen Konzil im Jahre 1967 vom Papst Paulus VI. veröffentlicht. Die mit neuen Medien, darunter mit den Portalen zusammenhängenden Inhalte wurden darin allerdings erst ab 1990 aufgenommen. Es war sowieso eine schnelle Reaktion aufs Erscheinen des Internets, das ein Hauptträger neuer Medien ist. Johannes Paul II sprach sie immer öfter in seinen Botschaften direkt an, was zu einer Regel ab 2009, d. h. ab den Pontifikaten von Benedikt XVI. und dann von Franziskus wurde. Mit der Zeit begannen zusammen mit der Entwicklung der Digital- und Medientechnik folgende Begriffe in den analysierten Botschaften zu erscheinen: „neue Medien“, „Globalisierung“, „Mobiltelefone“, „Cyberspace“, „SMS“, „Android“ und „Fake News“"35. Die Päpste wiesen immer auf die Rolle dieser Medien in der Gestaltung der heutigen Zivilisation hin, sowohl auf die Chance, die dieser Raum gibt, als auch auf die Gefahren. Sie wiesen auf die Notwendigkeit der christlichen

${ }^{35}$ Vergl. M. Wrzos, Neue Missionsmedien in Polen vor dem Hintergrund der Papstbotschaften zum Welttag der Massenmedien, in: „Studia Misjologiczne” 1 (8) 2018, S. 165-198. 
Formation sowohl der Sender als auch der Empfänger. Sie glaubten, sie sind zur Evangelisierung und einer gewissenhaften ekklesischen Information zu nutzen. Neue Medien sollen ein gegenwärtiger Areopag werden, ein Ort des Treffens, in der Dialogkultur, auch für Menschen unterschiedlicher Religionen und Kulturen. Sie sind eine Chance für die Vertiefung der Bindungen, jedoch auch eine Gefahr.

Die Anwesenheit der Gemeinschaft der Kirche und ihrer Institution im virtuellen Raum, insbesondere im Laienraum, ist notwendig und sogar unerlässlich, um die Evangelisierung mithilfe aller verfügbaren Mittel zu führen. Internet kann als vielschichtiger Raum sowohl ein Ort des Gedankenaustauschs, der Evangelisierung, als auch ein Werkzeug der Verkündung von Evangelium werden. J. Kloch erhebt eine Forderung, das Internet auch als Werkzeug der Evangelisierung zu nutzen. Er glaubt, die Kirche, ihre partikulären Gemeinschaften und Institutionen sollen dieses Werkzeug zur Verkündung der Frohen Botschaft (Evangelisierung, Katechesen, Information), zum Heiligen (Bibel, Gebet, Exerzitien, Informationen über Pilgerreisen), zum Verbreiten der Wohltätigkeit (Sozialhilfe, Freiwilligendienst, Zusammenarbeit, Bilden der Gemeinschaft um die Initiative) und zum Lehren (theologische Reflexion, Bildung der ekklesischen Gemeinschaft) ${ }^{36}$.

\section{Die Anwesenheit der Gemeinschaft der Kirche und ihrer Institution im virtuellen Raum, insbesondere im Laienraum, ist notwendig und sogar unerlässlich, um die Evangelisierung mithilfe aller verfügbaren Mittel zu führen.}

Obwohl die Reichweite der christlichen Internetportale nicht groß ist, wird die Kirchenlehre darin dargestellt. In den Laienportalen sind jedoch die Kirche und die Kirchenlehre in begrenztem Umfang anwesend. Die Frage der Erlangung der Daten ist erwähnenswert. Leider sinkt die Anzahl der veröffentlichten Mitteilungen betreffend die päpstlichen Pilgerreisen. Die meisten Nachrichten in den analysierten Portalen (www.onet.pl; www.wp.pl; www.interia.pl; www.gazeta.pl;

${ }^{36}$ Siehe J. Kloch, Kościół w Polsce wobec Web 2.0, Kielce 2013, S. 209-278. 
www.o2.pl; www.fakt.pl) wurden während der jeweiligen päpstlichen Pilgerreise und die übrigen bis 10 Tage davor und maximal 3 Tage danach, obwohl in einigen Fällen es der letzte Tag der Pilgerreise war, veröffentlicht (der Zeitunterschied bewirkte, dass die Nachrichten offiziell am nächsten Tag veröffentlicht wurden). Die die jeweilige Pilgerreise betreffenden Informationen „lebten“ somit ein paar Tage in den am meisten meinungsbildenden Portalen und zudem gab es wenig davon, denn im Durchschnitt rund 20 je apostolischer Besuch (21). Darunter gab es auch solche, z. B. betreffen Portugal oder Bangladesch, wo die Benachrichtigung über die päpstliche Pilgerreise sehr gering war bzw. mit der Beendigung der Pilgerreise zusammenfiel. Es wurde noch kein Werkzeug bearbeitet, das prüfen lässt, wie lange die jeweilige Nachricht auf der Hauptseite bleibt. Möglicherweise waren es nur Stunden oder Minuten. Am meisten wurden kopierte Agenturnachrichten ohne Kommentar veröffentlicht. Eine Ausnahme waren hier die Portale, die mit den katholischen Redaktionen eng zusammenarbeiten. Die engste Zusammenarbeit nahm der Portal www.onet.pl mit „Tygodnik Powszechny“ auf. Das Portal www.interia.pl nutze manchmal die Texte von „Przewodnik Katolicki“. In diesen zwei Portalen kann man die meisten theologische, obwohl einzelne Besprechungen und breitere Übermittlung der päpstlichen Lehre sehen. Es scheint, es sei der richtige Weg, damit so viele wie möglich mit dem Leben der Kirche verbundenen Informationen in den Internetmedien veröffentlicht werden und damit sie zuverlässig dargestellt werden. Um zur Veröffentlichung solcher Inhalte in diesen Portalen zu führen, müssen sie den Redaktionen zur Verfügung gestellt werden. Die Redaktionen sollen auch eine enge Zusammenarbeit mit bestimmtem katholischen Medium bzw. einem Theologen - Journalisten gewährleistet haben.

Es lohnt sich, dass die zentralen Kircheninstitutionen wie Nachrichtenbüro der Polnischen Bischofskonferenz oder der Pressesprecher der Apostolischen Nuntiatur eine Gruppe Menschen bilden würden, die sich mehr um die Anwesenheit der Kirche in den Medien durch Erstellung von die päpstlichen Pilgerreisen vorbereitenden bzw. zusammenfassenden Texten kümmern möchten. Auf ihren Seiten werden derartige Besprechungen üblicherweise nicht veröffentlicht. Wichtig, dass die Texte kommunikativ für den Empfänger sind und dass sie gemäß den Regeln des Internetjournalismus vorbereitet werden. Es können Laienfreiwilligen tun, den es lohnt sich, zu vertrauen und diesen Teil der Funktion der Kirch als den zu überlassen, die besser mit diesem Kommunikationswerkzeug umgehen können. Die Redaktionen, die fertige manchmal über interessante Elemente der 
Pilgerreise Mitteilungen oder Besprechungen erhalten, werden ein Werkzeug haben sie zu nutzen. Ein Teil davon nutzt keine Informationen von KAI aufgrund der Gebührenpflicht.

Gemäß der Forderung von J. Kloch ist eine breitere Anwesenheit der Kirche in den Internet- und Laienmedien möglich. Durch die Zusammenarbeit mit Internetmedien, die sich dafür interessieren, ist ihre noch breitere Nutzung möglich, insbesondere zur Evangelisierung, zu Katechesen, zur Information, zur Verkündung der ekklesischen Lehre zum jeweiligen Thema oder zum Bilden einer Gemeinschaft der Menschen, die sich an einer Initiative beteiligen möchten. Eine Voraussetzung scheint die Zusammenarbeit der Kirche mit diesen Medien und das Wirken der Menschen, die neue Medien nutzen können, zu sein. Die Pilgerreisen

\section{Die Voraussetzung für eine umfangreichere Anwesenheit der Kirche in neuen Medien ist die grundlegende Zusammenarbeit mit ihnen und gegenseitige positive Einstellung gegeneinander. Die Pilgerreisen von Papst Franziskus, die Missionen, das Engagement für Personen in den Peripherien sind Themen, die ein positives Image der Kirche in gesamtpolnischen neuen Medien bilden.}

des Papstes, seine Lehre, Missionen, Engagement für ausgeschiedene Personen, Tätigkeit der Jugend sind Themen, die ein positives Image der Kirche in neuen Medien bilden sollten.

Die Welt und die menschlichen Gewohnheiten ändern sich schnell. Zuerst erschienen unter den sozialen Kommunikationsmitteln Zeitschriften, Radio, Fernsehen und heute ist das Internet sowie neue es verwendende Medien das am meisten verbreitete Medium, das rund $70 \%$ der polnischen Gesellschaft nutzt. Junge Leute lesen sporadisch Zeitschriften, hören Radio, am häufigsten sind sie stets "online“ anhand der Computer und der Mobilgeräte (Telefone, Tablets, Uhren, 
Handschuhe usw.). Neben den Internetmedien wie Internetseiten, sozialen Medien (Facebook, Twitter, Google+, Instagram oder Pinterest) spielen derzeit die größte Rolle die beliebtesten publizistischen Portale. Manche von ihnen erreichen mehr als 18,2 Mio. Leser monatlich, die das Portal auch ein paar Mal täglich lesen (www.onet.pl). In ihren Ressourcen sollen sich mit der Kirche, darunter auch mit den päpstlichen Pilgerreisen zusammenhängende Informationen befinden.

Aus den durchgeführten Forschungen geht es hervor, dass die päpstlichen Pilgerreisen kleines bzw. sehr kleines Interesse der Portale genossen. Aus den vier päpstlichen Pilgereisen (28.-29. April - Ägypten; 12.-13. Mai - Portugal; 6.-11. September - Kolumbien; 27. November - 2. Dezember - Myanmar (Birma), Bangladesch wurden 84 Nachrichten veröffentlicht, somit im Durchschnitt 21 für alle Portale insgesamt. Am häufigsten waren es nach folgenden Agenturen veröffentlichte Nachrichten: der Katholischen Informationsagentur (KAI), der Polnischen Nachrichtenagentur (PAP), der Rundfunkinformationsagentur (RAI) und Radio Vatikan (RV). Ihre Anzahl beträgt 75 von 84, was 89,3\% der gesamten, oft kopierten Informationen in verschiedenen Portalen darstellt. Die Zeit der Veröffentlichung entsprach meistens der Zeit der apostolischen Reise selbst. Manchmal wurde sie durch Ankündigungen bzw. Zusammenfassungen eingeleitet, am häufigsten wurden sie jedoch nicht früher als 7 Tage veröffentlicht. Die sogenannte Lebensdauer einer päpstlichen Pilgerreise im Portal betrug durchschnittlich 7 Tage (so lange erschienen die Nachrichten zu diesem Thema, obwohl sie auf der Hauptseite nur für 2-3 Stunden anwesend waren) unter der Voraussetzung, dass die Pilgerreise überhaupt von der Redaktion des jeweiligen Portals bemerkt wurde. Der Anteil an negativen, positiven und neutralen Nachrichten war vergleichbar und unter den Portalen ist keines bemerkbar, das sich durch in Frage stellen der ekklesischen Tätigkeit auszeichnen würde.

Es scheint, dass die Zusammenarbeit mit den Internetmedien enger sein sollte. Die zentralen Institutionen der Kirche hätten bei der Vorbereitung der Informationen über die Tätigkeit der Kirche, bei der Zusammenarbeit mit den Laienredaktionen die Chance, ein positives Image zu kreieren sowie mehr Informationen oder theologischen Kommentaren zu veröffentlichen. Es ist wichtig, dass die Theologen, darunter Geistlichen, vorbereitet sind, sich der zu einem solchen Journalismus notwendigen Werkzeuge zu bedienen. Die Pilgerreisen des Papstes, insbesondere die Missionsreisen, seine Lehre, Missionen, Engagement 
für ausgeschiedene Personen, Tätigkeit der Jugend sind Themen, die ein positives Image der Kirche in neuen Medien bilden sollten.

Als Zusammenfassung und Antwort auf die Forschungshypothesen scheint es, dass die erste: „Die Medien in Polen informieren sachgemäß über die Auslandspilgerreisen von Papst Franziskus (quantitativ und qualitativ)“ sei unbestätigt. Die zweite: „Die Vorbereitung der Geistlichen zur Benutzung neuer Medien und zur Benachrichtigung über die mit der Kirche verbundenen Fragen ist sachgemäß“ ist unbestätigt; und die dritte: „Die Anzahl der Informationen und die Benachrichtigungsart über die Auslandspilgerreisen ist ungenügend“ sei bestätigt.

\section{BIBLIOGRAFIE}

\section{A. Analysierte Dienste.}

Https://www.fakt.pl, [Jahr 2017].

Https://www.gazeta.pl, [Jahr 2017].

Https://www.interia.pl, [Jahr 2017].

Https://www.o2.pl, [Jahr 2017].

Https://www.onet.pl, [Jahr 2017].

Https://www.wp.pl, [Jahr 2017].

\section{B. Sonstige Publikationen:}

Benedikt XVI., Orędzie na 43. Światowy Dzień Środków Społecznego Przekazu. Nowe technologie, nowe relacje. Trzeba rozpowszechniać kulturę szacunku, dialogu i przyjaźni, 24. Januar 2009.

Chudziński E. (Red.), Słownik wiedzy o mediach, Warszawa - Bielsko-Biała 2007

Franziskus I., Orędzie na 50. Światowy Dzień Środków Społecznego Przekazu Komunikacja i Miłosierdzie - owocne spotkanie, 24. Januar 2016.

Franziskus I., Orędzie na 52. Światowy Dzień Środków Społecznego Przekazu «Prawda was wyzwoli» (J 8, 32). Fake news a dziennikarstwo pokoju“ 24. Januar 2018.

Johannes Paul II., Orędzie na 24. Światowy Dzień Środków Społecznego Przekazu, Misja Kościoła w erze komputerów, 24. Januar 1990.

Kloch J., Kościół w Polsce wobec Web 2.0, Kielce 2013.

Marcin W., Zagraniczne podróże apostolskie, w tym misyjne, papieża Franciszka w najważniejszych krajowych portalach internetowych, cz. I (lata 2013-2014), in: „Kultura-Media-Teologia", 1 (28) 2017, S. 111-141.

Wrzos M., Neue Missionsmedien in Polen vor dem Hintergrund der Papstbotschaften zum Welttag der Massenmedien, in: „Studia Misjologiczne” 1 (8) 2018, S. 165-198.

Wrzos M., Zagraniczne podróże apostolskie, $w$ tym misyjne, papieża Franciszka w najważniejszych krajowych portalach internetowych, cz. II (rok 2015); in: „Kultura-Media-Teologia", 4 (31) 2017, S. 140-179. 
Wrzos M., Zagraniczne podróże apostolskie, $w$ tym misyjne, papieża Franciszka w najważniejszych krajowych portalach internetowych, cz. III (rok 2016); in: „Kultura-Media-Teologia“, 31 (2019), zum Druck gesetzt.

\section{Biogramm des Autors}

Marcin Wrzos OMI (geb. 1977), Priester, Missionar Oblate der Makellosen Jungfrau Maria; Doktor der Theologie im Fachgebiet Missionswissenschaft und Theologie der sozialen Kommunikationsmittel UKSW (2013), er absolvierte das Studium in politischen Wissenschaften und Journalismus UAM (2008) sowie Polonistik UJ (2016). Autor von Artikeln über Missionen in den sozialen Kommunikationsmitteln sowie über Nutzung der sozialen Kommunikationsmittel in Missionen. Er forscht die Anwesenheit der Kirche im Internet. Autor von vier Buchpublikationen: „Polskie czasopisma misyjne po II wojnie światowej. Studium misjologiczno-prasoznawcze“ „Bibliografia polskich czasopism misyjnych. Lata 1945-2013“, „Oblates missionary press in Europe“ (Redakteur) und "Główne idee teologiczne, historia i funkcje oblackiego czasopiśmiennictwa misyjnego w Polsce (19262016)" sowie von mehr als zehn wissenschaftlichen Artikeln. Ei ist freier Mitarbeiter der Fakultäten für Theologie der Universitäten UAM und USz. Er leitet die Veröffentlichung von „Misyjne Drogi“ und das Internetportal misyjne.pl. 


\section{Recenzenci 2019}

prof. WSiZ dr hab. Andrzej Adamski, Wyższa Szkoła Informatyki i Zarządzania w Rzeszowie ks. prof. UKSW dr hab. Jarosław Babiński, Uniwersytet Kardynała Stefana Wyszyńskiego w Warszawie prof. dr hab. Józef Bielak, Katolicki Uniwersytet w Ružomberoku, Słowacja o. dr hab. Wiesław Block OFMCap, Papieski Uniwersytet Antonianum w Rzymie, Włochy dr Philip Butler, Loyola Marymount University, USA ks. prof. WSPol dr hab. Sławomir Bylina, Wyższa Szkoła Policji w Szczytnie dr Tomira Chmielewska-Ignatowicz, Uniwersytet Kardynała Stefana Wyszyńskiego w Warszawie dr Kinga Cybulska, Uniwersytet Kardynała Stefana Wyszyńskiego w Warszawie dr Klaudia Cymanow-Sosin, Uniwersytet Papieski Jana Pawła II dr Beata Czechowska-Derkacz, Uniwersytet Gdański prof. PhD Pavol Dancák, Prešovská Univerzita v Prešove, Słowacja ks. prof. US dr hab. Andrzej Draguła, Uniwersytet Szczeciński dr Krzysztof Flasiński, Uniwersytet Szczeciński ks. prof. dr hab. Edward Jarmoch, Uniwersytet Przyrodniczo-Humanistyczny w Siedlcach

dr hab. Monika Kaczmarek-Śliwińska, Uniwersytet Warszawski prof. dr hab. Witold Kawecki, Uniwersytet Kardynała Stefana Wyszyńskiego w Warszawie dr Patryk Kencki, Instytut Sztuki Polskiej Akademii Nauk dr Anna Klas-Markiewicz, Uniwersytet Technologiczno-Humanistyczny im. K. Pułaskiego w Radomiu 
ks. prof. UKSW dr hab. Wojciech Kluj, Uniwersytet Kardynała Stefana Wyszyńskiego w Warszawie prof. dr hab. Dariusz Kowalczyk SJ, Papieski Uniwersytet Gregorianum w Rzymie, Włochy

ks. prof. dr hab. Janusz Królikowski, Uniwersytet Papieski Jana Pawła II o. dr Andrzej Kukła, Facoltà di Teologia di Lugano, Università della Svizzera Italiana, Włochy

prof. dr hab. Tadeusz Lewicki, Università Pontificia Salesiana, Roma, Włochy prof. UG dr hab. Małgorzata Łosiewicz, Uniwersytet Gdański prof. UKSW dr hab. Józef Łupiński, Uniwersytet Kardynała Stefana Wyszyńskiego w Warszawie doc. dr hab. Peter Majda, Uniwersytet Katolicki w Ružomberoku, Słowacja ks. prof. dr hab. Marian Machinek, Uniwersytet Warmińsko-Mazurski prof. dr hab. Józef Majewski, Uniwersytet Gdański dr Maria Makaruk, Uniwersytet Warszawski dr Anna Miotk, Uniwersytet Warszawski dr Sarka Novotna PhD, Masarykova Univerzita, Czechy dr Dariusz Piętka, Uniwersytet Kardynała Stefana Wyszyńskiego w Warszawie dr Tomasz Płonkowski, Uniwersytet Kardynała Stefana Wyszyńskiego w Warszawie dr Laura Polkowska, Uniwersytet Kardynała Stefana Wyszyńskiego w Warszawie prof. UJK dr hab. Joanna Senderska, Uniwersytet Jana Kochanowskiego w Kielcach o. prof. Ph.D. Paul A. Soukup SJ, Santa Clara University, USA dr Paweł Stangret, Uniwersytet Kardynała Stefana Wyszyńskiego w Warszawie ks. prof. dr hab. Janusz Szulist, Uniwersytet Mikołaja Kopernika w Toruniu ks. prof. UKSW dr hab. Tomasz Szyszka, Uniwersytet Kardynała Stefana Wyszyńskiego w Warszawie dr Małgorzata Ślarzyńska, Uniwersytet Warszawski dr Martin Taraj, Katolicki Uniwersytet w Ružomberoku, Słowacja ks. dr Paweł Tarasiewicz, Adler-Aquinas Institute, USA 
prof. UW dr hab. Dariusz Tworzydło, Uniwersytet Warszawski prof. dr. Andrius Vaišnys, Vilnius University, Litwa prof. KUL dr hab. Dariusz Wadowski, Katolicki Uniwersytet Lubelski prof. dr hab. Jan Wojciechowski, Akademia Sztuk Pięknych w Warszawie ks. prof. KUL dr hab. Jarosław Woźniak, Katolicki Uniwersytet Lubelski prof. UKSW dr hab. Małgorzata Wrześniak, Uniwersytet Kardynała Stefana Wyszyńskiego w Warszawie

prof. UKSW dr hab. Dominika Żukowska-Gardzińska, Uniwersytet Kardynała Stefana Wyszyńskiego w Warszawie 